UNIVERSIDADE DE SÃO PAULO

FACULDADE DE EDUCAÇÃO

MARIA DE FÁTIMA SERRA RIOS

LETRAMENTO DIGITAL NO ENSINO FUNDAMENTAL:

a intencionalidade educativa de seu design pedagógico 


\title{
LETRAMENTO DIGITAL NO ENSINO FUNDAMENTAL: a intencionalidade educativa de seu design pedagógico
}

\author{
Versão Corrigida
}

Tese apresentada ao Programa de Pós-Graduação em Educação, da Faculdade de Educação da Universidade de São Paulo para obtenção do título de Doutor em Educação.

Área de Concentração: Didática, Teorias de Ensino e Práticas Escolares

Orientadora: Profa. Dra. Stela Conceição Bertholo Piconez 
AUTORIZO A REPRODUÇÃO E DIVULGAÇÃO TOTAL OU PARCIAL DESTE TRABALHO, POR QUALQUER MEIO CONVENCIONAL OU ELETRÔNICO, PARA FINS DE ESTUDO E PESQUISA, DESDE QUE CITADA A FONTE.

Catalogação na Publicação

Serviço de Biblioteca e Documentação

Faculdade de Educação da Universidade de São Paulo

\subsection{6 \\ R586L}

Rios, Maria de Fátima Serra

Letramento digital no ensino fundamental: a intencionalidade educativa de seu design pedagógico / Maria de Fátima Serra Rios; orientação Stela Conceição Bertholo Piconez. São Paulo: s.n., 2018. 188 p. ils.; grafs.; tabs.; anexos; apêndices

Tese (Doutorado - Programa de Pós-Graduação em Educação. Área de Concentração: Didática, Teorias de Ensino e Práticas Escolares) - - Faculdade de Educação da Universidade de São Paulo.

1. Formação de professores 2. Letramento digital 3. Ensino Fundamental II I. Piconez, Stela Conceição Bertholo, orient. 


\section{MARIA DE FÁTIMA SERRA RIOS}

Título: Letramento Digital no Ensino Fundamental: a intencionalidade educativa de seu design pedagógico

Tese apresentada ao Programa de Pós-Graduação em Educação, da Faculdade de Educação da Universidade de São Paulo para obtenção do título de Doutor em Educação.

Aprovado em: $27,09 \quad 12018$

\section{Banca Examinadora \\ Abtudiut \\ Profa. Dra. Stela Conceição Bertholo Piconez}

Faculdade de Educação da Universidade de São Paulo - FEUSP

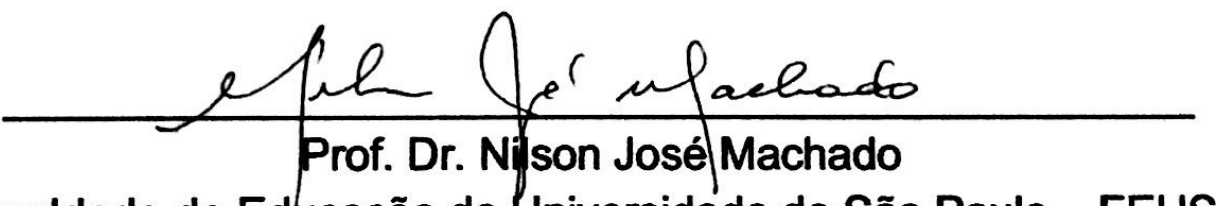

Faculdade de Educação da Universidade de São Paulo - FEUSP

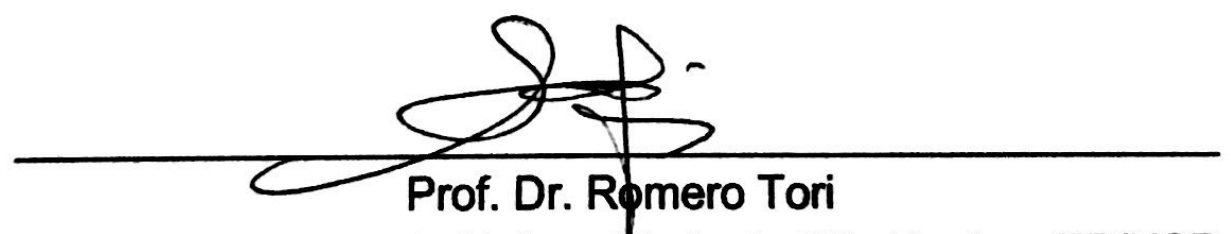

Escola Politécnica da Universidade de São Paulo - EP/USP

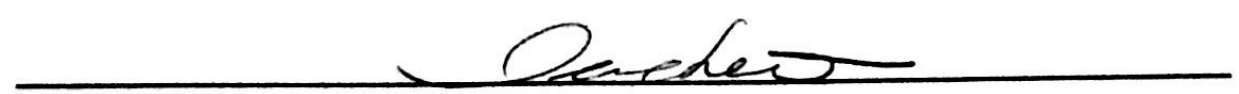

Prof (a). Dr (a). Márcia Maria Dias Reis Pacheco

Universidade de Taubaté - UNITAU

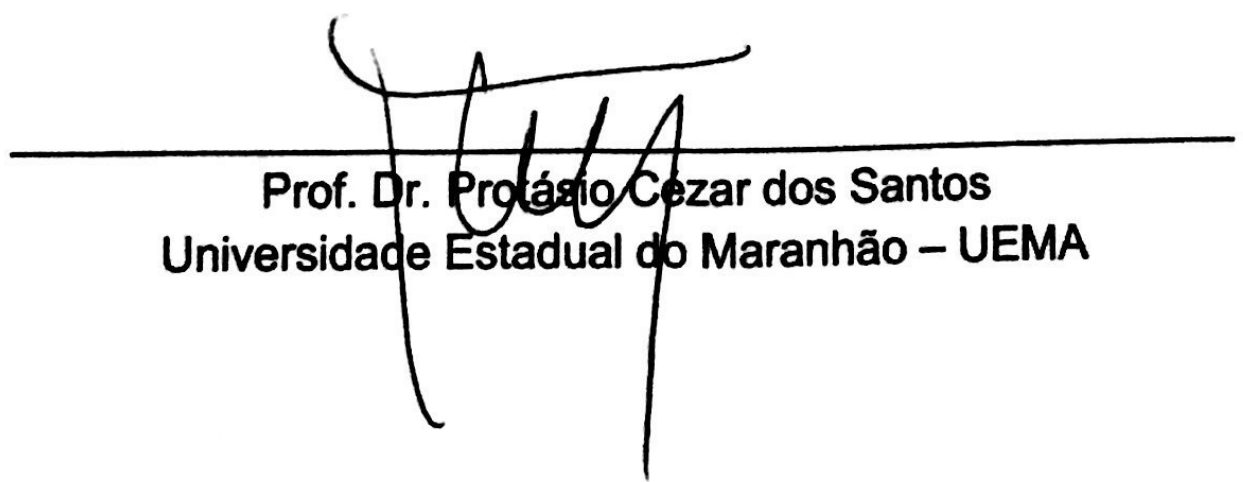


À minha família e amigos. 


\section{AGRADECIMENTOS}

A Emanuel, pelo privilégio de significativas reflexões e mudanças.

A todos da minha família, por sempre me incentivarem a prosseguir.

À Universidade Estadual do Maranhão (UEMA), na pessoa do Magnífico Reitor Prof. Dr. Gustavo Pereira da Costa, pelo apoio financeiro, tão necessário à formação docente.

À Profa. Dra. Stela Conceição Bertholo Piconez, pela orientação provocativa e, sobretudo pelo exemplo de compromisso com a educação escolar e com a pesquisa.

Aos professores da Banca de Qualificação Prof. Dr. Nílson José Machado e Profa. Dra. Márcia Maria Dias Reis Pacheco, pelas valorosas contribuições, que enriqueceram o trabalho.

Aos professores da Faculdade de Educação da Universidade de São Paulo (FE/USP): Prof. Dr. Nílson José Machado, Profa. Dra. Sandra Zákia Lian Sousa, Profa. Dra. Sílvia de Mattos Gasparian Colello, Profa. Dra Stela Conceição Bertholo Piconez, Prof. Dr. Ulisses Ferreira de Araújo e Profa. Dra. Valeria Araújo, pela oportunidade de pensar a educação sob diferentes perspectivas.

Ao Corpo gestor e docente da Escola Estadual Fernando Nobre, Cotia, SP, pelo convite para contribuir com a cultura digital escolar e abertura à pesquisa.

Aos professores das Oficinas de Orientação de Estudos e aos alunos, pela oportunidade de construção conjunta do Design pedagógico para o Letramento Digital contextualizado.

Aos colegas do Grupo Alph@ de Pesquisa da FE/USP: Adalberto Bosco Pereira, Édison Trombeta de Oliveira, Fábio Alves de Oliveira, Jean Rafael Tomceac, João José Bignetti Bechara, Leandro Fabrício Campelo, Luciana Gonçalves Platero, Lílian Bacick, Luís Carlos Soares, Maria Raidalva Nery Barreto, Paula Cristina Lameu, Stela Conceição Bertholo Piconez (coordenadora científica) e, em especial, a Josete Maria Zimmer, pela parceria nas produções acadêmicas, fruto de muitas reflexões conjuntas sobre o tema desta investigação.

À Caroline Mendes, Yuri Nogueira e Josimar Almeida, pelo apoio tecnológico.

À Fátima Ribeiro, Lucirene Lopes, Marcos Furlan e Rudi Zimmer, pelas revisões de texto.

À Secretaria da Pós-Graduação da FE/USP, pela competência e atenção nas orientações e solicitações administrativas. 
“[...] Modifiquemos a escola. Pra mim, a questão não é acabar com ela, mas é mudá-la completamente, é radicalmente fazer que nasça dela um corpo que não mais corresponde à verdade tecnológica do mundo, um novo ser tão atual quanto a tecnologia. Quer dizer, eu continuo lutando no sentido de por a escola à altura do seu tempo. E por a escola à altura do seu tempo não é soterrá-la, sepultá-la. Mas é refazê-la." 


\section{RESUMO}

O contexto escolar tem se deparado com demandas de duas ordens. Por um lado, a vivência em um mundo no qual a presença das Tecnologias Digitais de Informação e de Comunicação (TDIC) exige mudanças na forma de pensar e de agir. Por outro lado, o ensino tradicional, com predomínio da transmissão expositiva e avaliação pautada no processo mnemônico dos conteúdos curriculares, passa por descompasso. Isto impõe às escolas mudanças de design pedagógico apoiado por recursos tecnológicos digitais. Os estudos sobre Letramento Digital revelam a necessidade de integração das TDIC ao centro do processo de ensino-aprendizagem. Entretanto, são reduzidos os estudos sobre a temática que envolvem imersão na realidade escolar. Neste espaço há uma confluência de diferentes dimensões, que compõem uma complexidade importante a ser considerada, sobre o desenvolvimento de competências digitais. O Letramento Digital, como processo de desenvolvimento de competências para acessar, localizar, selecionar, organizar informações, construir e compartilhar conhecimentos, visa o alcance de possibilidades de protagonismo na resolução de problemas. Nesta pesquisa, o Letramento Digital foi utilizado como referência à criação de um design pedagógico, cuja intencionalidade educativa atribuída à seleção das TDIC trouxe contribuições ao processo de ensinoaprendizagem. Com natureza de pesquisa-ação, os dados da investigação foram coletados em uma escola pública de tempo integral no município de Cotia (SP), a Escola Estadual Fernando Nobre, durante imersão de um ano letivo. O Design pedagógico foi construído coletivamente, resultante das inter-relações entre novas informações, reflexão e experiências dos professores e alunos. Ficou evidenciada a urgência de sua implementação diante das mudanças decorrentes das evoluções tecnológicas, econômicas e sociais. Esta pesquisa reconheceu a importância estratégica de integração das TDIC para ampliar as práticas de desenvolvimento de uma cultura digital. O Design pedagógico sob perspectiva de Letramento Digital mobilizou um Ciclo de Ações Educativas para desenvolvimento das habilidades docentes de mapear, narrar, tecer e mediar. Contribuiu para o entendimento dos desafios existentes nas dimensões infraestrutura, administrativa-pedagógica, didática-pedagógica e pessoal. Estimulou o desenvolvimento do Letramento Digital integrado ao planejamento escolar, o que ampliou as habilidades de busca de informação, comunicação e compartilhamento em múltiplos formatos. O Design pedagógico criado permitiu ampliar habilidades que tiveram, como resultado, maior sentido e significado sobre a apropriação das TDIC e do desenvolvimento do Letramento Digital. O uso de blogs, redes sociais e diferentes aplicativos incentivaram novas práticas de ensino e aprendizagem, de comunicação e de interação. Ampliouse na direção de uma educação emancipatória, autônoma, coletiva e ética, expressas nos trabalhos escolares. O corpo docente enfrenta desafios para se atualizar, justificados pela acelerada evolução das TDIC. Por esta razão, a formação docente deve ser permanente, a fim de estimular a autonomia dos sujeitos, para a construção dialógica de saberes na busca de soluções para os problemas escolares. A imersão na realidade da escola representou terreno fértil de pesquisa para a compreensão da complexidade do Letramento Digital em contexto escolar.

Palavras-chave: Formação Docente. Letramento Digital. Design pedagógico. Ensino Fundamental II. Oficinas de Orientação de Estudos. 


\begin{abstract}
The school context has been faced with demands of two orders. On the one hand, living in a world in which the presence of Digital Information and Communication Technologies (DICT) requires changes in the way of thinking and acting. On the other hand, traditional teaching, with predominance of expository transmission and evaluation based on the mnemonic process of curricular contents, goes through mismatch. This imposes on schools changes in pedagogical design supported by digital technological resources. Studies on Digital Literacy highlight the need to integrate DICT to the center of the teaching-learning process. However, studies on the subject involving immersion in school reality are reduced. In this space there is a confluence of different dimensions, which compose an important complexity to be considered, on the development of digital skills. Digital Literacy, as a process of developing skills to access, locate, select, organize information, build and share knowledge, aims at reaching possibilities of protagonism in solving problems. In this research, Digital Literacy was used as reference to the creation of a Pedagogical Design, whose educational intentionality attributed to the selection of the DICT brought contributions to the teaching-learning process. With an action-research nature, research data were collected at a full-time public school in the city of Cotia (State of São Paulo), the Fernando Nobre State School, during a one-year immersion. The Pedagogical Design was built collectively, resulting from the interrelations between new information, reflection and experiences of teachers and students. The urgency of its implementation was evident in the face of changes resulting from technological, economic and social developments. This research recognized the strategic importance of integrating DICT to broaden the practices of developing a digital culture. The Pedagogical Design under the perspective of Digital Literacy mobilized a Cycle of Educational Actions to develop the teaching skills of mapping, narrating, weaving and mediation. It contributed to the understanding of the existing challenges in the dimensions infrastructure, administrative-pedagogical, didactic-pedagogical and personal) It stimulated the development of Digital Literacy integrated with school planning, which expanded information search, communication and sharing abilities in multiple formats. The Pedagogical Design created allowed to expand abilities that have, as a result, greater sense and meaning on the appropriation of the DICT and the development of Digital Literacy. The use of blogs, social networks and different applications encouraged new teaching and learning practices, communication and interaction. It has expanded towards an emancipatory, autonomous, collective and ethical education expressed in school work. The faculty faces challenges to be updated, justified by the accelerated evolution of the DICT. For this reason, teacher education must be permanent, in order to stimulate the autonomy of the subjects, for the dialogical construction of knowledge, for the solutions to school problems. Immersion in the school reality represented fertile ground for research to understand the complexity of Digital Literacy in a school context.
\end{abstract}

Keywords: Teacher Training. Digital Literacy. Pedagogical Design. Elementary School II. Study Guidance Workshops. 


\section{LISTA DE ILUSTRAÇÕES}

Tabela 2.1 - Número de teses e dissertações, segundo o descritor, por Base de dados (2008-2017)

Tabela $\quad 2.2$ - Número de teses e dissertações em Letramento Digital no Ensino Fundamental, segundo a Grande área, por Base de dados (2008-2017)

Tabela

2.3 - Número de teses e dissertações - Letramento

Digital/Ensino Fundamental, segundo o período de publicação, por Grande área (2008-2017)

Tabela 2.4 - Número de teses e dissertações - Letramento Digital no

Ensino Fundamental, segundo o nível de ensino, por Grande área (2008-2017)

Quadro

2.4 - Teses e Dissertações - Educação Ensino Fundamental II

Tabela

2.5 - Número de artigos em periódicos, segundo o descritor, por Base de dados (2008-2017)

Quadro

2.5 - Artigos - Educação/Ensino Fundamental II/equivalente

Mapa

2.1 - Dimensões do Letramento Digital na revisão de estudos

Mapa

2.2 - Procedimentos, técnicas e instrumentos - Pesquisa-ação

Mapa

2.3 - Estratégias de Pesquisa para o Design pedagógico

68

Mapa

2.4 - TDIC na Ação Implementada

70

Gráfico

3.3 - Qualidade da informação, segundo os alunos

79

Figura

4.1 - Ciclo de Ações Educativas apoiadas por TDIC

100

Figura

5.1 - Ciclo de Ações Educativas apoiadas por TDIC no Design

112 pedagógico referenciado pelo Letramento Digital

Quadro

2.1 - Teses e Dissertações - Educação

159

Quadro

2.2 - Teses e Dissertações - Linguística, Letras e Artes

160

Quadro

2.3 - Teses e Dissertações - Outras áreas

163

Quadro

2.6 - Síntese das dimensões analisadas na pesquisa

178

Quadro

4.1 - Estruturantes didáticos no Design pedagógico

183

Gráfico

3.1 - Proporção de professores, por aproximação com TDIC

185

Gráfico

3.2 - Proporção de alunos, por aproximação com TDIC

185

Tabela

3.1 - Fatores de perdas e danos no uso da Internet

186

Tabela

3.2 - Perdas e danos no uso da Internet, por área afetada

186

Gráfico

5.1 - Proporção de alunos, por ação com TDIC

186

Gráfico

5.2 - Proporção de alunos, por dificuldades no uso do Blog

187

Gráfico

5.3 - Proporção de alunos, por sugestão de mudanças para as Oficinas

Gráfico 5.4 - Local de cesso dos alunos ao Blog

Quadro 4.2 - Especificações no Blog Pesquisa Nobre 


\section{LISTA DE SIGLAS}

$\begin{array}{ll}\text { ABNT } & \text { Associação Brasileira de Normas Técnicas } \\ \text { AMI } & \text { Alfabetização Midiática e Informacional } \\ \text { ARPAnet } & \text { Agência para Projetos de Pesquisa Avançada } \\ \text { AVA } & \text { Ambiente Virtual de Aprendizagem } \\ \text { BDTD.IBICT } & \text { Biblioteca Digital Brasileira de Teses e Dissertações do IBICT } \\ \text { BDTD.USP } & \text { Biblioteca Digital de Teses e Dissertações da USP } \\ \text { BIOE } & \text { Banco Internacional de Objetos Educacionais } \\ \text { BNCC } & \text { Base Nacional Comum Curricular } \\ \text { BYOD } & \text { Bring your own device } \\ \text { Capes } & \text { Coordenação de Aperfeiçoamento de Pessoal de Nível } \\ & \text { Superior } \\ \text { CEP } & \text { Comitê de Ética em Pesquisa } \\ \text { Cetic.br } & \text { Centro Regional de Estudos para o Desenvolvimento da } \\ & \text { Sociedade da Informação } \\ \text { CGI.br } & \text { Comitê Gestor da Internet no Brasil } \\ \text { Cieb } & \text { Centro de Inovação para a Educação Brasileira } \\ \text { Conep } & \text { Comissão Nacional de Ética em Pesquisa } \\ \text { CT.Capes } & \text { Catálogo de Teses e Dissertaçães da Capes } \\ \text { CVFP } & \text { Centro Virtual de Formação Permanente } \\ \text { DCN } & \text { Diretrizes Curriculares Nacionais da Educação Básica } \\ \text { DICT } & \text { Digital Information and Communication Technologies } \\ \text { EEFN } & \text { Escola Estadual Fernando Nobre } \\ \text { EJA } & \text { Educação de Jovens e Adultos } \\ \text { ETI } & \text { Escola de Tempo Integral } \\ \text { EUA } & \text { Estados Unidos da América } \\ \text { FE/USP } & \text { Faculdade de Educação da USP } \\ \text { HTPC } & \text { Horário de Trabalho Pedagógico Coletivo } \\ \text { IBICT } & \text { Instituto Brasileiro de Informação em Ciência e Tecnologia } \\ \text { IFAP } & \text { Information for All Programme } \\ \text { IFSUL } & \text { Instituto Federal Sul Rio-Grandense } \\ \text { INEP } & \text { Instituto Nacional de Estudos e Pesquisas Educacionais } \\ \text { INES } & \text { Instituto Nacional de Educação de Surdos } \\ \text { IsF } & \text { Idiomas sem Fronteiras } \\ \text { LDB } & \text { Lei de Diretrizes e Bases da Educação Nacional } \\ \text { MCT } & \text { Ministério da Ciência e Tecnologia } \\ \text { MEC } & \text { Ministério de Educação } \\ \text { Moodle } & \text { Modular Object-Oriented Dynamic Learning Enviroment } \\ \text { NLG } & \text { New London Group } \\ \text { NLS } & \text { New Literacy Studies } \\ \text { NMC } & \\ & \text { Nonsortium }\end{array}$




$\begin{array}{ll}\text { PBLE } & \text { Programa Banda Larga nas Escolas } \\ \text { PCK } & \text { Pedagogical Content Knowledge } \\ \text { PCN } & \text { Parâmetros Curriculares Nacionais } \\ \text { PDF } & \text { Portable Document Format } \\ \text { PEI } & \text { Programa de Ensino Integral } \\ \text { PNLD } & \text { Programa Nacional do Livro Didático } \\ \text { Proinfo } & \text { Programa Nacional de Informática na Educação } \\ \text { Prolnfo Integrado } & \text { Programa Nacional de Tecnologia Educacional } \\ \text { Proninfe } & \text { Programa Nacional de Informática Educativa } \\ \text { Prouca } & \text { Programa Um Computador por Aluno } \\ \text { Prouni } & \text { Programa Universidade para Todos } \\ \text { PUC } & \text { Pontifícia Universidade Católica } \\ \text { Redalyc } & \text { Red de Revistas Cientificas de América Latina y el Caribe, } \\ & \text { España y Portugal } \\ \text { SciELO } & \text { Scientific Electronic Library Online } \\ \text { SE/SP } & \text { Secretaria da Educação do Estado de São Paulo } \\ \text { Sisu } & \text { Sistema de Seleção Unificada } \\ \text { TCK } & \text { Technological Content Knowledge } \\ \text { TCLE } & \text { Termo de Consentimento Livre e Esclarecido } \\ \text { TDIC } & \text { Tecnologias Digitais de Informação e Comunicação } \\ \text { TIC } & \text { Tecnologias de Informação e Comunicação } \\ \text { TPACK } & \text { Technological Pedagogical Content Knowledge } \\ \text { TPK } & \text { Technological Pedagogical Knowledge } \\ \text { UCA } & \text { Um Computador por Aluno } \\ \text { UCS } & \text { Universidade de Caxias do Sul } \\ \text { UEMA } & \text { Universidade Estadual do Maranhão } \\ \text { UEMG } & \text { Universidade Estadual de Minas Gerais } \\ \text { UFC } & \text { Universidade Federal do Ceará } \\ \text { UFPE } & \text { Universidade Federal de Pernambuco } \\ \text { UFPR } & \text { Universidade Federal do Paraná } \\ \text { UFSC } & \text { Universidade Federal de Santa Catarina } \\ \text { UFU } & \text { Universidade Federal de Uberlândia } \\ \text { Unesco } & \text { Organização das Nações Unidas para a Educação, } \\ & \text { a Ciência e a Cultura } \\ \text { Unicamp } & \text { Universidade Estadual de Campinas } \\ \text { UNIVILLE } & \text { Universidade da Região de Joinville } \\ \text { USP } & \text { Universidade de São Paulo } \\ \text { www } & \text { World Wide Web } \\ & \end{array}$




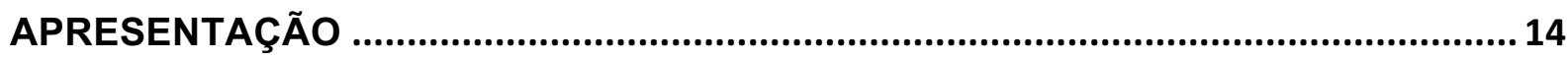

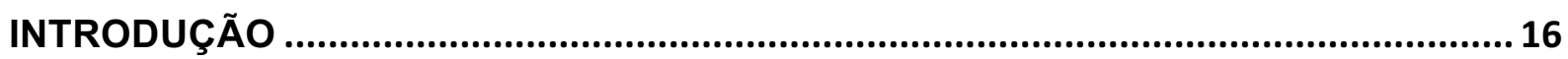

1 LETRAMENTO DIGITAL: MÚLTIPLOS SIGNIFICADOS ...........................................22

1.1 LETRAMENTO DIGITAL NO CENÁRIO INTERNACIONAL....................................22

1.2 LETRAMENTO DIGITAL NO CENÁRIO NACIONAL ...........................................30

1.3 PROGRAMAS E PESQUISAS NACIONAIS E O LETRAMENTO DIGITAL ...............36

2 LETRAMENTO DIGITAL: REVISÃO DE ESTUDOS E A TRAJETÓRIA

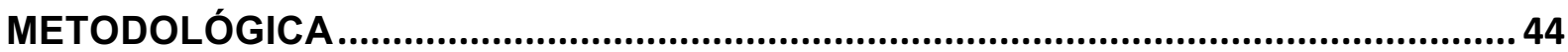

2.1 LETRAMENTO DIGITAL NA PRODUÇÃO ACADÊMICA …………………............44

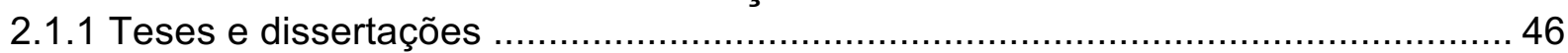

2.1.2 Artigos em periódicos nacionais e internacionais ...........................................52

2.2 CONFIGURAÇÃO DA PESQUISA: A DIMENSÃO EMPÍRICA …..........................57

2.2.1 Procedimentos de coleta e tratamento de dados ...............................................59

2.2.2 Estratégias da Ação implementada e as questões éticas ....................................... 67

3 A ESCOLA ESTADUAL FERNANDO NOBRE: O CONTEXTO DA PESQUISA.........71

3.1 CONTEXTO POLÍTICO-ADMINISTRATIVO-PEDAGÓGICO E TECNOLÓGICO ....71

3.2 PARTICIPANTES DA PESQUISA E A FLUÊNCIA DIGITAL ……........................76

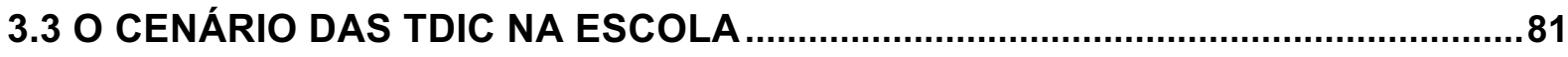

4 O DESIGN PEDAGÓGICO COM SUPORTE DAS TDIC...........................................91

4.1 ABORDAGEM METODOLÓGICA NA AÇÃO IMPLEMENTADA …….....................92

4.2 O CICLO DE AÇÕES EDUCATIVAS APOIADAS POR TDIC ……......................99

5 LETRAMENTO DIGITAL: CONTRIBUIÇÕES DO DESIGN PEDAGÓGICO ..............110

5.1 MOVIMENTO NAS OFICINAS COM O DESIGN PEDAGÓGICO ............................111

5.2 DESAFIOS NO USO DAS TDIC NO CONTEXTO ESCOLAR .............................124

5.3 A ÓTICA DOS PARTICIPANTES SOBRE AS AÇÕES DE LETRAMENTO DIGITAL.126

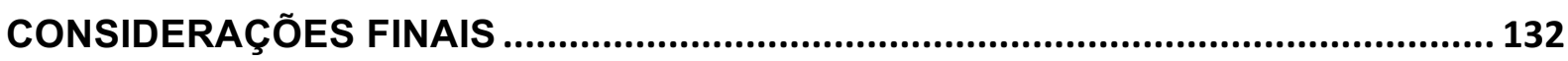

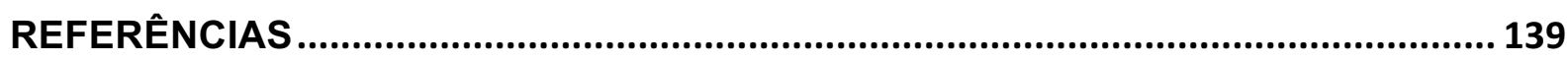

ANEXO A - Estrutura Curricular da Escola .................................................................. 156

ANEXO B - Modelo de Plano de Ensino do Professor ........................................... 157

APÊNDICE A - Produção acadêmica mapeada (2008-2017) ....................................... 159

APÊNDICE B - Diários de campo ………........................................................... 164

APÊNDICE C - Guia para Pesquisa Documental ........................................................ 168

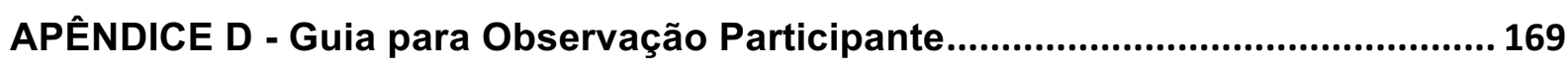

APÊNDICE E - Questionário A - Sondagem diagnóstica com professores ........... 170

APÊNDICE F - Questionário B - Sondagem diagnóstica com alunos .................... 171

APÊNDICE G - Questionário C - Avaliação da Ação por professores ...................... 172

APÊNDICE H - Questionário D - Avaliação da Ação por alunos ............................. 174

APÊNDICE I - Questionário E - Avaliação da Ação por observadores .................... 175 
APÊNDICE J - Guia para Entrevistas Semiestruturadas..................................... 176

APÊNDICE K - Guia para Grupo Focal............................................................ 177

APÊNDICE L - Síntese das categorias analisadas na pesquisa, por dimensão .... 178

APÊNDICE M - Termo de Consentimento Livre e Esclarecido.............................. 181

APÊNDICE N - Estruturantes didáticos no design pedagógico ............................. 183

APÊNDICE O - Dados Estatísticos da Pesquisa ..................................................... 185

APÊNDICE P - Especificações no Blog Pesquisa Nobre ......................................... 188 


\section{APRESENTAÇÃO}

Esta tese é fruto da experiência de formadora-pesquisadora na Universidade Estadual do Maranhão (UEMA) e de membro do Grupo Alph@ de Pesquisa da Faculdade de Educação da Universidade de São Paulo (FE/USP).

Apresenta as ações de construção de significados para o uso de $\operatorname{TDIC}^{1}$ no processo de ensino-aprendizagem, sob a perspectiva do Letramento Digital, em contexto escolar, como resultado da pesquisa de doutorado no Programa de PósGraduação da FE/USP.

Situa além da Introdução, o Capítulo 1 - Letramento Digital: múltiplos significados, que identifica a complexidade envolvida na compreensão dos significados do Letramento Digital em nível internacional e nacional. Apresenta o panorama das iniciativas do Governo Federal desenvolvidas pelo Ministério de Educação (MEC) para a inserção das TDIC nas escolas brasileiras.

O Capítulo 2 - Letramento Digital: revisão de estudos e a trajetória metodológica destaca os resultados do levantamento realizado para a revisão da literatura sobre Letramento Digital no recorte temporal de 2008 a 2017, em bases nacionais e internacionais de pesquisa, com destaque para produções acadêmicas avaliadas por pares (teses e dissertações). Caracteriza a investigação, expõe o encaminhamento conferido às escolhas de procedimentos e de técnicas empregadas, combinadas com as fases da investigação. Explicita as estratégias da pesquisa-ação, as estratégias de criação e de implementação do design pedagógico, bem como as questões éticas.

O Capítulo 3 - A Escola Estadual Fernando Nobre: o contexto da pesquisa descreve o campo onde ocorreu a investigação, com elementos do contexto políticoadministrativo-pedagógico e tecnológico; especifica seus espaços, a organização e o componente curricular do Ensino Fundamental, a Oficina de Orientação de Estudos, foco da ação na pesquisa. Apresenta os participantes e caracteriza a fluência digital existente, em termos de uso das tecnologias digitais.

\footnotetext{
1 Nesta tese é adotado o termo TDIC, porém, serão respeitados nas citações os termos utilizados por outros autores, como por exemplo Tecnologias de Informação e Comunicação (TIC), o que poderá ocasionar alternância em seu uso.
} 
No Capítulo 4 - $O$ Design pedagógico com suporte das TDIC apresenta o design pedagógico criado para trabalhar com TDIC nas Oficinas de Orientação de Estudos, sob a perspectiva do Letramento Digital; e descreve a abordagem junto aos professores e alunos e a rede de significações na proposta desenvolvida.

No Capítulo 5 - Letramento Digital: contribuições do Design pedagógico registra reflexões da pesquisadora e dos participantes ao identificar a complexidade da adoção de atividades escolares apoiadas por TDIC, voltadas para desenvolvimento da cultura digital escolar. Reconhece a importância estratégica de integração das tecnologias digitais no contexto escolar, assim como suas contribuições.

Nas Considerações Finais reitera as contribuições referenciadas pelo Letramento Digital ao processo de ensino-aprendizagem. Destaca alternativas estratégicas do planejamento pedagógico. Conclui que as TDIC tratadas com intencionalidade educativa favorecem 0 desenvolvimento de habilidades recomendadas pela legislação educacional; e direcionam o trabalho pedagógico para uma educação emancipatória, autônoma, coletiva e ética. Registra as reflexões de entendimento sobre o contexto escolar que demanda interação de diferentes dimensões: infraestrutura; administrativa-pedagógica; didática-pedagógica e pessoal.

Finalmente são apresentadas as Referências, Anexos e Apêndices. 


\section{INTRODUÇÃO}

Muitas informações e conhecimentos construídos para a Educação Escolar sempre foram contemplados em livros e outros registros escritos. No entanto, a vivência na era das tecnologias digitais, por meio dos equipamentos, aplicativos e telas muldimidiáticas tem ampliado de forma diferente o acesso a todo e qualquer conhecimento.

As TDIC têm impulsionado a cultura e a economia global. Seu uso frequente tem gerado mudanças sociais e culturais no desenvolvimento da linguagem, nos modos de criação, de comunicação e de compartilhamento de conteúdos. Elas têm sido inseridas em todos os setores da vida. Representam, contudo, grandes desafios quando se trata de sua incorporação na Educação Escolar.

Professores e alunos podem atuar no mundo digital (online e off-line), no qual a leitura e a escrita concorrem com os inúmeros recursos midiáticos. Isto significa que é preciso investimento para a viabilidade da apropriação das TDIC nas escolas.

Portanto, o investimento em TDIC, o seu uso e a formação em instituições educacionais são imprescindíveis. Desconsiderar sua interferência no espaço formal das escolas tem se revelado algo inadequado e trará consequências.

Nessa dinâmica das TDIC na sociedade, o letramento tem sido considerado um fenômeno que envolve práticas com a língua escrita e as demandas sociais de seu uso (SOARES, 2014). A complexidade conferida ao conceito letramento encontra-se em constante transformação, pois as TDIC têm alterado tais práticas.

A natureza do letramento continua em ampliação, pois as práticas, que antes priorizavam a leitura e a escrita de textos impressos e manuscritos, exigem agora o uso compartilhado e a criação de textos multimidiáticos que abrangem, de certa forma, o conhecimento das funcionalidades e desafios impostos por tantas e tão diferentes ferramentas e recursos digitais.

A visibilidade desses fatos é inquestionável. Se hoje se defende a relevância da autonomia e do protagonismo docente e discente, o que está sendo desenvolvido nesse sentido? Qual o papel das escolas frente à exposição informal dos alunos aos modelos educativos de formação (redes sociais, aplicativos e recursos tecnológicos multimidiáticos), os quais tratam a todos como iguais, estabelecem as mesmas expectativas e replicam conhecimentos inseridos nas disciplinas escolares? 
Há inúmeras diferenças entre os espaços formais e os informais. E estes últimos têm se tornado a opção preferida dos alunos. Em paralelo, é cada vez mais comum o fato de professores enfrentarem dificuldades em se atualizar, dada a velocidade e abrangência da evolução das TDIC. Vale ressaltar que essa dificuldade nem é maior, nem menor das que ocorreram em outras épocas, se constituiu apenas como diferente, mas igualmente importante. É necessário se atentar para a inclusão das TDIC nas escolas, seus mecanismos e estratégias, assim como para o cuidado na seleção de recursos digitais adequados.

Os dados e informações via Web (rede de conhecimentos) ${ }^{2}$, suportados pela Internet (rede de computadores) ${ }^{3}$, possuem uso social, tanto por professores, como por alunos. Estes últimos, em número cada vez mais crescente, têm descoberto e utilizado em suas jornadas letramentos ainda não contemplados pelos componentes curriculares e têm vivenciado o descompasso entre suas experiências de comunicação online e as atividades ocorridas na Educação Escolar, pois esta continua sendo tratada com padrões tradicionais e conteúdos clássicos, centrados em provas, cópias de textos e em aulas expositivas.

Não se pode desconsiderar a presença ubíqua das TDIC nos processos de letramento (uso social da língua escrita), conforme referido anteriormente. $\mathrm{Na}$ realidade, de acordo com a legislação educacional vigente, inúmeras habilidades são necessárias para atuar em uma sociedade em constante transformação, na qual o Letramento Digital não deve ser tratado simplesmente como uma questão tecnológica.

Muitos estudos filosóficos e sociológicos têm abordado as mudanças ocorridas nas dimensões de acessibilidade, na velocidade das informações e nas transformações das mesmas; e têm refletido sobre a globalização dos espaços culturais e transformações de seus usuários, dentre outros aspectos (CASTELLS, 1999; LÉVY, 1993, 1998a, 1998b). Por mais de duas décadas o debate tem ocorrido e os documentos de legislação educacional o incorpora em sua letra de lei. Entretanto, não são todos os países que têm incorporado aos seus projetos de formação docente e atualização de recursos tecnológicos nas escolas com facilidade, inclusive o Brasil.

\footnotetext{
2 World Wide Web (www ou Web) - conjunto de protocolos que permite consulta remota de arquivos e usa a Internet como meio de transmissão, criada na década de 1990.

3 Internet - conjunto descentralizado de redes de comunicação interconectadas, o que garante a divulgação e troca de mensagens eletrônicas entre computadores, mundialmente. Tem sua origem na conexão de computadores, conhecida como ARPAnet, Agência para Projetos de Pesquisa Avançada, criada pelo Departamento de Defesa dos EUA, em 1969.
} 
Existem muitas intenções inspiradas no reconhecimento da urgência da apropriação das tecnologias, mas há pouca ação nesse sentido. As que se efetivam, esbarram no descompasso existente, a exemplo do embate atual sobre usar os celulares dos alunos, exposto na proposta Bring your own device ${ }^{4}$ - (BYOD), como alternativa de superar a precária infraestrutura tecnológica escolar.

O Letramento Digital tem sido percebido como um requisito que favorece a inclusão social e representa referencial importante para o desenvolvimento de novas competências que vão surgindo no contexto das velozes mudanças tecnológicas, isto é uma condição para ser cidadão.

A Unesco (2000) destaca em seu Programa Informação para Todos [(Information for All Programme (IFAP)], a relevância do Letramento Digital (Alfabetização Informacional) para a realização dos objetivos da sociedade da informação; o reconhece como um direito humano básico no mundo digital; e o define como competência para a vida, em todas as suas áreas, capaz de promover integração social e condições aos sujeitos para tomarem decisões essenciais sobre a própria vida.

Organismos internacionais têm compartilhado na Web relatórios ${ }^{5}$ com pressupostos que inferem a necessidade de se tratar o Letramento Digital em pesquisas, na Educação Escolar e na formação docente. Documentos da Organização das Nações Unidas para a Educação, Ciência e Cultura (UNESCO, 2009a, 2009b; WILSON et al., 2013); e os Horizon Reports, realizados pelo New Media Consortium (NMC, 2004) são alguns exemplos. No cenário nacional ${ }^{6}$, pesquisas TIC Educação, do Centro Regional de Estudos para o Desenvolvimento da Sociedade da Informação (CETIC.br, 2011) e estudos do Centro de Inovação para Educação Brasileira (CIEB, 2016a, 2016b) também têm compartilhado dados e informações com recomendações relevantes.

A escola encontra-se diante de grande desafio: o de se organizar e de se modificar para atender às necessidades de mudanças nos modos de ensinar e de aprender. $\mathrm{E}$ isso diz respeito a diversas questões, como por exemplo, a formação

\footnotetext{
4 BYOD é uma estratégia de utilização de aparelhos pessoais para acesso de dados e informações no próprio local de estudo e/ou trabalho.

5 Unesco: <http://www.unesco.org>; NMC Horizont Report (edições de 2004 a 2017):

$<$ https://www.nmc.org/publication-type/horizon-report/>.

6 Cetic.br (edições 2010 a 2016): <https://cetic.br/pesquisa/educacao/publicacoes/>; Cieb:

$<$ http://www.cieb.net.br>.
} 
docente, a infraestrutura, a incorporação regular dos dispositivos digitais em salas de aula ou mesmo nos conhecidos Laboratórios de Informática, além de considerar os textos produzidos pelos alunos nas redes sociais, por vezes tidos como irrelevantes.

Notadamente, as escolas públicas não recebem de forma sistemática investimentos para aquisição, atualização e manutenção de computadores e aplicativos, e, primordialmente, uma formação docente permanente para vencer os desafios das modificações impostas pelos avanços das tecnologias.

No contexto escolar, o modelo tradicionalmente usado para classificar os conteúdos das disciplinas escolares tem sido criticado e ainda representa uma barreira para a aprendizagem e para o ensino, por limitar as possibilidades de construção inter e transdisciplinar diante do apoio e suporte digital e em rede (PICONEZ, 2004).

As aprendizagens, realizadas a partir da Internet, provocam mudanças na Educação Escolar, mas a integração das TDIC no currículo não tem sido uma tarefa fácil (ALMEIDA; VALENTE, 2011).

Com esse cenário, as inquietações da formadora-pesquisadora são crescentes. Se competências digitais vêm sendo consideradas como um direito humano, quais mudanças estão sendo previstas e ocorrendo na complexidade do contexto escolar, corresponsável por tal conquista? A informação disponibilizada por diferentes espaços virtuais tem agregado valor ao desenvolvimento dos conteúdos conceituais, procedimentais e atitudinais determinados em documentos oficiais? Como as práticas educativas apoiadas por TDIC abarcam a multimodalidade de recursos? Estas práticas têm considerado os conhecimentos multiculturais dos alunos?

Estas inquietações e problemática fez surgir um conjunto de questionamentos importantes para esta investigação, tais como: O que significa Letramento Digital e como ocorre o seu desenvolvimento no contexto escolar? Ele é apenas uma questão de conhecimento dos equipamentos, aplicativos e de suas funcionalidades? A escola possui infraestrutura adequada para o trabalho educativo com TDIC? Quais as condições da escola para desenvolver o Letramento Digital, tendo em vista o desenvolvimento de sua cultural digital? Como se dá a formação docente nesse sentido? A prática docente com TDIC supõe novas formas de planejar?

A relevância das recomendações teóricas sobre Letramento Digital requer estudo do contexto escolar para entendimento de sua apropriação. 
Diante de tais questionamentos, sem ter a pretensão de esgotá-los, esta investigação procurou contemplar um desenvolvimento articulado de práticas alternativas, utilizando-se as TDIC; ora mapeando, ora narrando, ora tecendo e mediando novas significações.

A dimensão bibliográfica e documental investigou a produção acadêmica nacional e internacional sobre concepções de Letramento Digital, para familiarização sobre o tema e para compreender as relações existentes em seus significados e práticas.

Na dimensão empírica, com natureza de pesquisa-ação, dada a imersão no contexto escolar, investigou os desafios e as contribuições em práticas de implementação do Letramento Digital, referenciadas por estudos e documentos oficiais.

Buscou-se investigar a hipótese de que o Letramento Digital no contexto escolar traz contribuições: apoia a formação docente para usar TDIC e amplia espaços e ações para desenvolvimento da aprendizagem. Requer um design pedagógico que contemple intencionalidade educativa na seleção e uso das tecnologias digitais.

Para tanto, foi delineado um objetivo geral e alguns objetivos específicos de pesquisa. Como objetivo geral procurou-se investigar as contribuições do Letramento Digital no contexto escolar e alternativas estratégicas que contemplem intencionalidade educativa.

A imersão da formadora-pesquisadora no contexto do Ensino Fundamental II, possibilitou a configuração dos objetivos específicos:

a) elaborar um quadro comparativo do contexto político-administrativopedagógico e tecnológico na escola-campo, para compreender as influências e contribuições durante o período de intervenção;

b) constatar a presença de Letramento Digital e a fluência digital dos professores e alunos participantes da pesquisa;

c) estudar, criar, implementar e acompanhar as práticas educativas apoiadas por ações integradas às TDIC fortalecidas com 0 desenvolvimento de conhecimentos, habilidades e atitudes inspirados pelo conceito de Letramento Digital e seus desdobramentos; e

d) mapear, narrar, tecer e mediar relações do manifestado e do percebido em ações apoiadas por TDIC. 
Partiu-se do pressuposto que o Letramento Digital pode referenciar as ações de formação docente em práticas educativas com TDIC. Contudo, a complexidade do contexto escolar não pode ser desconsiderada pela pesquisa. Por isso, os objetivos foram formulados em um continuum teórico-prático, possibilitado pela metodologia da pesquisa-ação, para contribuir com a interpretação crítica dos resultados e oferecer subsídios para a reflexão e continuidade do estudo. 


\section{LETRAMENTO DIGITAL: MÚLTIPLOS SIGNIFICADOS}

Este Capítulo apresenta aspectos conceituais do Letramento Digital, sua natureza epistemológica, origens, convergências além de suas modificações desde o surgimento do termo. Destaca os entendimentos expostos na literatura acadêmica internacional e nacional, e nas descrições dos termos alcançados na revisão da temática. Apresenta o pensamento dos principais autores que contribuíram para a evolução histórica de seus desdobramentos.

Tem por objetivo aclarar sua conceituação e abrangência, expressa em termos de Letramentos Múltiplos e Multiletramentos, incluindo o uso das tecnologias, representado como Letramento Digital.

Ao se tratar do emprego do termo referente ao Letramento Digital (Português do Brasil) existe uma multiplicidade de expressões - Alfabetización Mediática, Informacional ou Digital (Espanhol), Digital Literacy (inglês), Literacia Mediática (Português de Portugal). Como variantes, são encontradas uma série de expressões, tais como: Letramento ou Alfabetização Tecnológica, Letramento ou Alfabetização em TIC e Letramento ou Alfabetização Computacional dentre outros.

A articulação dos conceitos apresentados nesta investigação constituiu o horizonte de referência, com a intenção de oferecer subsídios para a interpretação e análise dos dados coletados.

As Seções 1.1 e 1.2 expõem a dimensão histórica internacional e nacional de Letramento Digital, identificada na literatura sobre o tema.

\subsection{LETRAMENTO DIGITAL NO CENÁRIO INTERNACIONAL}

Os primeiros estudos sobre letramento no âmbito internacional datam de 1984, com o registro de pesquisas de Brian Street (1984), professor e pesquisador da área de linguística, do King's College London. Como antropólogo social, questionou o conceito e publicou um tratado destinado inicialmente a outros antropólogos, linguistas e sociólogos, explicando que o termo literacy poderia ser compreendido como uma prática social (STREET, 1984). 
Porém, o termo literacy foi empregado na área da Psicologia em 1981, por Scribner e Cole $^{7}$ (1981, p. 236 apud BAWDEN, 2008, p. 5, tradução nossa), correspondendo a "um conjunto de práticas socialmente organizadas que utilizam a escrita, enquanto um sistema de símbolos e uma tecnologia para produzi-la e divulgála." Essa concepção refere-se ao sentido da capacidade de codificação e decodificação de um sistema simbólico.

Com a obra de Street (1984), o letramento passou a ser concebido como um ato social, uma forma de prática comunicativa e apresenta dois tipos de letramentos: o letramento autônomo e o letramento ideológico. No primeiro, as habilidades são aprendidas independente do contexto social e tem um caráter individual; no segundo, tem uma visão cultural das práticas de letramento e é variável de acordo com o contexto social e cultural.

Bawden $(2002,2008)$ observa que as diversas expressões (ou a ideia geral) se originam do inglês Digital Literacy, tornando os termos Alfabetización Informacional y Digital mais conhecidos a partir dos estudos de Paul Gilster, em 1997, no seu livro Digital Literacy.

Gilster (1997, p. 33) trata o tema de forma ampla, definindo como a "capacidade para entender e utilizar a informação em múltiplos formatos, a partir de uma gama de fontes, quando esta se apresenta por meio de computadores." Apresentou elementos que envolvem conhecimentos e competências básicas sobre o uso das tecnologias, como a capacidade para realizar buscas de informação na Internet, orientadas por buscadores; para ler e compreender hipertextos ${ }^{8}$; para fazer juízos de valor das informações obtidas, com atitude de cautela sobre a validade e exaustividade do material acessado; para produzir conhecimentos confiáveis a partir das fontes encontradas; para gerenciar e organizar documentos e informações obtidas; para usar a rede para interagir com outras pessoas para pedir ou dar ajuda e discutir temas; e para compreender um problema e procurar informações para resolvê-lo.

Nessa década de 1990 e no cenário internacional, o seu significado se ampliou com as pesquisas em diversas áreas do conhecimento: linguística, história, antropologia, retórica e estudos de escrita, psicologia, educação, dentre outras. Esses estudos foram denominados de New Literacy Studies (NLS) (GEE, 2009).

\footnotetext{
7 SCRIBNER, Sylvia; COLE, Michael. The psychology of literacy. Cambridge: Harvard University Press. 1981.

8 Para Xavier (2007, p. 6), hipertexto é "a página eletrônica da Internet que permite acesso simultâneo do leitor a textos, imagens e sons de modo interativo e não-linear, possibilitando visitar outras páginas e assim controlar até certo ponto sua leitura-navegação na grande rede de computadores".
} 
No contexto do letramento escolar, o NLS abrangeu estudos sobre as relações entre a tecnologia e letramento, tais como o de Barton e Hamilton (1998); Gee (2000, 2003, 2004, 2007, 2008, 2009); Knobel e Lankshear (2002, 2008, 2014); Lankshear et al. (2007a, 2007b); e Street (1993, 1995, 1997, 2005).

O NLS defendia a ideia do letramento primordialmente social e cultural, não apenas um processo cognitivo (visão psicológica tradicional). O NLS considerava o fenômeno da alfabetização como um modo de inserção social, de participação, a ser entendido e estudado nos diversos contextos que envolvem a sociedade. Entendiam que leitores e escritores estavam engajados em práticas culturais e sociais, nas quais a escrita estaria vinculada da oralidade e da ação, e determinariam, inclusive, diferentes linguagens, as quais incluem "diferentes formas de agir e interagir; diferentes maneiras de conhecer, valorizar e acreditar; e, também, muitas vezes diferentes maneiras de usar vários tipos de ferramentas e tecnologias." (GEE, 2009, p. 2, tradução nossa).

A partir dessa perspectiva, não haveria apenas um tipo de letramento, mas sim diversas maneiras de apropriação de algum tipo de linguagem, ou vários letramentos (BARTON; HAMILTON, 1998), o que depende da experiência em práticas nas quais as pessoas estivessem inseridas.

Portanto, Barton e Hamilton (1998) se referem à existência de vários letramentos, que diferem com o contexto (social, político, tecnológico, por exemplo), e o digital seria mais um deles. Segundo esses autores, os tipos de letramentos mudam porque são situados historicamente e acompanham as mudanças dos diferentes contextos na sociedade.

A partir dos estudos de um grupo de pesquisadores, denominado de New London Group (NLG), desde 1996, e com a publicação do Manifesto sobre os Multiletramentos e, em 2000, com o livro "Multiliteracies: Literacy learning and the design of social futures", de Cope e Kalantzis (COPE; KALANTZIS, 2009), o termo passou a alcançar dois aspectos característicos das sociedades globalizadas - a multiplicidade de canais de comunicação e mídia, e a diversidade cultural e linguística (COPE; KALANTZIS, 2000).

Com as TDIC surgem novas formas de ensinar e de aprender, considerando que na era digital "a escrita, a leitura, a escuta, o jogo e a composição musical, a visão e a elaboração das imagens, a concepção, a perícia, o ensino e o aprendizado, 
reestruturados por dispositivos técnicos inéditos, estão ingressando em novas configurações sociais." (LÉVY, 1998b, p. 17).

O Letramento Digital é sem dúvida uma condição importante nessa sociedade, estando relacionado "a um conjunto de técnicas materiais e intelectuais, de práticas, de atitudes, de modos de pensamentos e valores que se desenvolvem juntamente com o crescimento do ciberespaço." (LÉVY, 1999, p. 17).

Ao discutir o tema, vários pesquisadores como Bawden (2002, 2008); Coll; Illera (2010) e Pérez Tornero (2004) têm apresentado revisão de conceitos e termos, sem, no entanto, esgotar a questão da multiplicidade existente internacionalmente.

Warschauer (2006), ao discutir a inclusão digital e tecnologias como prática social, aborda a questão do acesso e do letramento. Apresenta considerações relevantes sobre categorias prévias ao Letramento Digital ou Letramento Eletrônico, a saber: Letramento Computacional; Letramento Informacional; Letramento Multimidiático e Letramento Comunicacional.

Para o autor, o Letramento Computacional ou Letramento por meio do computador é expresso pela fluência na utilização de equipamentos eletrônicos, hardware, software, sistemas operacionais e consiste na manipulação física e operacional de um dispositivo. Esse letramento não tem fim em si mesmo, sendo básico para aprendizagens mais amplas (WARSCHAUER, 2006).

O Letramento Informacional é expresso pela capacidade de localização, avaliação e utilização da informação. Inclui a elaboração de perguntas pertinentes para efetuar pesquisas; o planejamento prévio de busca das informações; o uso de ferramentas e estratégias apropriadas; a avaliação da confiabilidade da autoria das fontes; e a organização, controle e citação das informações localizadas. Envolve conhecimentos específicos, tanto do uso do computador em si, quanto da leitura crítica das fontes, carregando uma responsabilidade pessoal por sua seleção. 0 Letramento Informacional é considerado decisivo para a transformação dos dados e das informações em conhecimento (WARSCHAUER, 2006).

O Letramento Multimidiático é expresso pela capacidade de interpretação, criação e produção de conhecimento, exigidos à representação da informação com texto, imagens, vídeos, áudios, material gráfico e planos de fundo em formato multimodal (WARSCHAUER, 2006).

O Letramento Comunicacional ou Letramento para comunicação mediada pelo computador é expresso pela capacidade de comunicação na Internet. Incorpora desde 
as regras de comportamento na rede, a capacidade de argumentação e persuasão nas diversas mídias, até saber fazer (know-how) na administração da comunicação para benefício de outrem em grupos ou organizações (WARSCHAUER, 2006).

Novos argumentos foram acrescentados pela abordagem britânica de Buckingham (2010), que enriqueceu a compreensão do tema. Defende a reflexão de que Letramento Digital implica bem mais que uma questão funcional ou instrumental de saber usar equipamentos eletrônicos, softwares, e fazer pesquisas na Web, dentre outras habilidades básicas e necessárias. Enfatiza que para transformar a informação em conhecimento é preciso que a informação seja avaliada e usada criticamente. Isto significa conhecer a fonte da informação, o interesse do seu produtor, as formas como representa o mundo, além de compreender como a tecnologia se relaciona com as "forças sociais, políticas e econômicas mais amplas." (BUCKINGHAM, 2010, p. 49). Discute quatro aspectos conceituais gerais como componentes essenciais ao Letramento Digital, sobretudo no aspecto informacional, sendo eles: representação; língua; produção e audiência.

Esse autor chama a atenção sobre a representação das mídias digitais, que refletem o mundo, o representam, incorporam valores e ideologias de forma implícita nas suas interpretações e seleções da realidade.

Para Buckingham (2010, p. 50), os usuários "necessitam ser capazes de avaliar o material que encontram", identificando as motivações dos criadores da mídia e comparando com outras fontes, inclusive com a própria experiência. "Nos textos informativos, significa abordar questões sobre autoridade, confiabilidade e tendência; e também questões mais amplas sobre as vozes que são ouvidas e os pontos de vista que são representados ou não o são."

Em relação à língua, ele destaca que o letramento envolve a capacidade de usar a língua, compreender como funciona, compreender a gramática das formas de comunicação e a "consciência dos códigos e das convenções mais amplos de determinados gêneros. Significa adquirir habilidade analítica e uma metalinguagem para descrever como funciona a língua." (BUCKINGHAM, 2010, p. 50).

Buckingham (2010, p. 50), em referência à produção, destaca que há três importantes elementos: "quem está comunicando, para quem e por quê". E alerta para o fator segurança quanto aos interesses comerciais, muitas vezes invisíveis ao usuário. Faz parte do Letramento Digital a "consciência mais ampla do papel global de publicação, promoção e patrocínio, e como elas influenciam a natureza da 
informação inicial disponível." O autor observa que tal compreensão deve ser considerada na presença de fontes que não apresentam fins comerciais, mas que usam a Web para persuadir e influenciar o usuário.

A audiência, continua o autor, envolve a consciência da própria posição, a de usuário ou leitor, conhecendo como é alvo da mídia, como "diferentes audiências usam e respondem à mídia", e ainda reconhecer como a mídia é utilizada e como pode ser usada de modo diferente. "No caso da Internet, isso implica uma consciência de como os usuários têm acesso aos sites, como são abordados e guiados (ou estimulados a navegar) e como são reunidas informações sobre eles." (BUCKINGHAM, 2010, p. 51).

Coll e Illera (2010), por sua vez, chamam a atenção para a clareza dos significados do tema e optam pelo uso da expressão "Alfabetização Digital", por acreditarem que seja mais inclusiva e a que melhor reflete as aprendizagens associadas às TDIC e à sociedade da informação. Sustentam que é importante a aprendizagem para o uso de recursos digitais, porém argumentam que o contexto, os objetivos, os fins e a forma de uso também são essenciais e precisam ser considerados.

As abordagens ao longo dos anos trataram diferentes aspectos, como o funcional, o instrumental e a perspectiva sociocultural, mais crítica e contextualizada.

Há que se ressaltar a amplitude do conceito e do foco natural de análise de cada autor, relacionado ao avanço das tecnologias digitais. A informação ocupa o centro das abordagens, as quais indicam em seu conjunto, a ideia complexa do Letramento Digital.

Além do domínio dos recursos digitais, há menção ao caráter pessoal, relativo às habilidades cognitivas, ligadas às múltiplas formas de expressão da informação; e às habilidades socioemocionais, inerentes aos processos de comunicação no ambiente virtual.

Nesse cenário polissêmico, no qual há carência de fundamentação de base metodológica, a Unesco com o objetivo de "harmonizar diferentes pontos de vista e nomenclaturas em relação ao uso das TIC na formação dos professores." (UNESCO, 2009a, p. 5), tem exercido papel fundamental com sua iniciativa de definição de padrões internacionais e harmonização das diferentes noções terminológicas:

Alfabetização midiática. Alfabetização informacional. Liberdade de expressão e alfabetização informacional. Alfabetização no uso de bibliotecas. Alfabetização no acesso a notícias. Alfabetização computacional. 
Alfabetização no uso da Internet. Alfabetização digital. Alfabetização cinematográfica. Alfabetização no uso de jogos. Alfabetização televisiva. alfabetização publicitária. (WILSON et al., 2013, p. 19).

A Unesco objetiva melhorar a prática docente e contribuir para um sistema de ensino de qualidade, tendo em vista o desenvolvimento econômico e social. Trata das TDIC e da formação de professores em um conjunto de documentos publicados em $2008 / 2009^{9}$ e $2011 / 2013^{10}$.

No contexto de formação permanente de professores se insere o documento derivado do "Projeto de Padrões de Competência em TIC para Professores", que referencia o exercício da docência (UNESCO, 2009a, 2009b). Para complementar essa série, a Unesco publicou a Matriz Curricular e de Competências em Alfabetização Midiática e Informacional (AMI), que inclui Módulos Centrais e os Módulos Complementares do currículo, organizados em unidades e se relacionam às competências em AMI (WILSON et al., 2013).

Para Wilson et al. (2013), a sigla AMI:

[...] se refere às competências essenciais (conhecimentos, habilidades e atitudes) que permitem que os cidadãos engajem-se junto às mídias e outros provedores de informação de maneira efetiva, desenvolvendo o pensamento crítico e a aprendizagem continuada de habilidades a fim de socializarem-se e de tornarem-se cidadãos ativos. (WILSON et al., 2013, p. 182).

Os autores Wilson et al. (2013) optam por empregar a palavra "alfabetização", aproximando-se da expressão "Alfabetización Informacional", que tem sido corrente na língua espanhola, tanto na Espanha, como em países da América. Justificam que no Brasil os termos "Alfabetização e Letramento" são empregados em referência às habilidades de leitura e escrita.

A Matriz Curricular e de Competências em AMI para formação de professores combina no conceito AMI duas áreas distintas - a midiática e a informacional. Esse conceito único vai além do que significam as terminologias isoladamente. Incorporam tanto a ênfase da importância ao "acesso à informação e a avaliação do uso ético dessa informação." (WILSON et al., 2013, p. 18), quanto a ênfase à "capacidade de compreender as funções da mídia, de avaliar como essas funções são desempenhadas e de engajar-se racionalmente junto às mídias com vistas à autoexpressão." Wilson et al. (2013) assim as definem:

Alfabetização informacional - A expressão refere-se à habilidade de reconhecer quando as informações são necessárias e como localizar, avaliar,

\footnotetext{
${ }^{9}$ A versão original do documento foi publicada em 2008, e a versão em Português, em 2009 (ver UNESCO, 2009a, 2009b).

${ }^{10}$ A versão original foi publicada em 2011, e em 2013, a versão em Português (ver WILSON et al., 2013).
} 
utilizar de forma eficaz e comunicar informações em seus diversos formatos. Alfabetização midiática - A compreensão e o uso das mídias de massa de maneira incisiva ou não, incluindo um entendimento bem informado e crítico das mídias, das técnicas que elas empregam e dos seus efeitos. Também inclui a capacidade de ler, analisar, avaliar e produzir a comunicação em uma série de formatos de mídias (por exemplo, televisão, mídias impressas, rádio, computadores etc.). Pode ainda ser compreendida como a capacidade de decodificar, analisar, avaliar e produzir comunicações de diversas formas. (WILSON et al., 2013, p. 181).

Em paralelo, este documento apresenta o significado para Alfabetização Digital, como:

\begin{abstract}
A habilidade de usar tecnologias digitais, ferramentas de comunicação ou redes para localizar, avaliar, usar e criar informações. Também se refere à capacidade de entender e usar as informações em múltiplos formatos a partir de diversas fontes, apresentadas por computador, ou à capacidade de uma pessoa efetivamente desempenhar tarefas em um ambiente digital. A alfabetização digital inclui a habilidade de ler e interpretar as mídias, reproduzir dados e imagens pela manipulação digital e avaliar e aplicar novos conhecimentos obtidos a partir de ambientes digitais. (WILSON et al., 2013, p. 181).
\end{abstract}

A expectativa da Unesco é que essa matriz curricular seja testada em sistemas de educação em todo o mundo e que as competências em AMI possam "equipar os cidadãos com habilidades de raciocínio crítico, permitindo que eles demandem serviços de alta qualidade das mídias e de outros provedores de informação." (WILSON et al., 2013, p. 16).

Nos Estados Unidos da América (EUA), desde 1993, destacam-se os trabalhos do $\mathrm{NMC}^{11}$, grupo de empresas que iniciou investimentos em pesquisas de desenvolvimento e aplicação de tecnologias para superar os desafios no ensino, na aprendizagem e na investigação criativa.

O NMC publica desde 2004 os Horizon Reports em parcerias ${ }^{12}$ de pesquisa com a comunidade acadêmica e estabeleceu convênios com escolas para capacitação docente. Os relatórios têm por objetivo apontar tendências e desafios no processo de ensino-aprendizagem com as TDIC. A primeira publicação destinada às pesquisas sobre aplicação das TDIC na educação básica internacional ${ }^{13}$ foi realizada em 2009 (NMC, 2004).

\footnotetext{
${ }^{11}$ O NMC foi fundado por um grupo de desenvolvedores de software e hardware (Apple Computer, Adobe Systems, Macromedia e Sony) unido a editores, com a percepção de que para ampliar o acesso de produtos multimídia precisariam da aceitação da comunidade de Ensino Superior. Então, escolheram 22 universidades para estabelecer parcerias de pesquisas aplicadas à inserção da tecnologia no ensino. Em fevereiro de 2018 o NMC foi adquirido pelo Educause (NMC, 2004).

12 Parceria com editores, ensino superior, escolas de educação básica (K-12), museus e bibliotecas acadêmicas dos EUA, Canadá, Austrália e muitos outros países, incluindo o Brasil (NMC, 2004).

13 Para representar o período da educação básica americana, canadense e de algumas partes da Austrália é utilizada a designação comum: K-12, correspondente à educação básica brasileira do primeiro ciclo do Ensino Fundamental ao terceiro ano do Ensino Médio (NMC, 2004).
} 
O Relatório "Horizon Report 2017 K-12 Edition" menciona que as escolas são responsáveis pelo desenvolvimento da "cidadania digital" dos alunos, no sentido de contribuir para o uso responsável e apropriado da tecnologia, em atenção inclusive à etiqueta online e aos direitos e responsabilidades (NMC, 2017).

No Brasil as discussões sobre o tema iniciaram na década de 1980. Com a Constituição Federal de 1988, Art. 5², inciso XIV, a informação é expressamente um direito do cidadão e cabe ao Estado a promoção do acesso, a fim de potencializar a construção de práticas cidadãs (BRASIL, 1988). As considerações no âmbito nacional estão descritas na próxima Seção.

\subsection{LETRAMENTO DIGITAL NO CENÁRIO NACIONAL}

Não havendo consenso sobre o que fosse exatamente a expressão "literacy"14, e na falta de uma palavra que designasse o "processo de estar exposto aos usos sociais da escrita, sem no entanto, saber ler nem escrever" surgiu o neologismo letramento (TFOUNI, 2010, p. 10).

O termo letramento tem sido empregado na literatura brasileira principalmente nas áreas da Linguagem e da Educação, relacionado à alfabetização. Embora não se tenha a perspectiva de delimitar esta investigação nos processos de leitura e escrita em particular, não se pode deixar de abordar a base do entendimento dos termos e conceitos envolvidos.

Segundo Soares $(1998 / 2014)^{15}$, os estudos e pesquisas sobre o letramento no Brasil tiveram início na década de 1980, sendo atribuído o primeiro uso do termo (literacy) na publicação "No mundo da escrita: uma perspectiva psicolinguística", de Kato em 1986.

O termo também foi utilizado em 1988, no livro "Adultos não alfabetizados: o avesso do avesso", de Leda Verdani Tfouni, e que se constitui de um estudo sobre o modo de falar e de pensar de adultos analfabetos, no qual a autora se dedicou à definição e distinção entre alfabetização e letramento. E em 1995, Angela Kleiman

\footnotetext{
${ }^{14}$ Soares (2014) comenta que o termo illiteracy (negativa de literacy) era usado desde o século XVII nos dicionários de língua inglesa dos Estados Unidos e Inglaterra, e que só no final do século XIX passou a ser registrado o termo literacy, chegando ao Brasil somente no final do século XX.

${ }^{15}$ Soares publicou a primeira edição do livro Letramento: um tema em três gêneros em 1998.
} 
publicou o livro intitulado "Os significados do letramento: uma nova perspectiva sobre a prática social da escrita".

No contexto educacional brasileiro, a década de 1990 foi marcada também por ações de regulamentação das políticas educacionais. Foram evidenciadas pela Lei de Diretrizes e Bases da Educação Nacional (LDB), promulgada em 1996, e pelos Parâmetros Curriculares Nacionais (PCN), publicados em 1997. Os objetivos desses documentos previam a garantia de ensino de práticas de leitura e escrita para todos (BRASIL, 1996, 1997a).

Embora o termo letramento não estivesse dicionarizado no Brasil em meados dessa década, já eram estudados tanto a alfabetização, quanto o impacto social da escrita. O conceito sofreu mudanças, sendo definido por Kleiman (1995, p. 19) como "um conjunto de práticas sociais que usam a escrita, como sistema simbólico e como tecnologia, em contextos específicos, para objetivos específicos."

Tfouni $(1988,2010)$ evidencia as diferenças entre alfabetização e letramento ao relacionar o termo letramento diante das práticas sociais de leitura e escrita e as mudanças geradas em uma sociedade letrada. A autora trata o conceito de letramento sob a perspectiva social, além da perspectiva individual. Reitera que a alfabetização, se refere "à aquisição da escrita, enquanto aprendizagem de habilidades para a leitura, escrita e as chamadas práticas de linguagem." (TFOUNI, 2010, p. 11). Já o letramento "focaliza os aspectos sócio-históricos da aquisição de um sistema escrito por uma sociedade." (TFOUNI, 2010, p. 22).

Soares (1998/2014), em seus estudos sobre letramento explica a origem das palavras envolvidas: alfabetização, literacy e letramento ${ }^{16}$. O alfabetismo para esta autora é um estado, uma condição, e o modo de proceder de quem conhece o alfabeto, isto é, que sabe ler e escrever. Esse conceito é bastante complexo por envolver tanto as capacidades de leitura como as de escrita, as quais são múltiplas e variáveis. Quanto ao letramento, afirma que sua definição "é uma tarefa altamente controversa; a formulação de uma definição que possa ser aceita sem restrições parece impossível." No entanto, ressalta que para fins de avaliação e medição de

\footnotetext{
${ }^{16}$ A palavra alfabetização é composta por: "alfabet" (alfabeto) + sufixo "iza" ( $r$ ) (tornar, fazer com que) + sufixo "ção" (ação) e significa "a ação de alfabetizar", alfabetizar por sua vez, "é tornar o indivíduo capaz de ler e escrever." O termo letramento é resultante da tradução para o português da palavra inglesa literacy, composta por: "litera" (palavra latina littera = letra) + sufixo "cy" (qualidade, condição ou estado), significando: the condition of being literate (a condição de ser letrado). A palavra letramento é composta por: "letra" (palavra latina littera = letra) + o sufixo "mento" (indica resultado de uma ação) (SOARES, 2014).
} 
níveis de letramento é necessária uma definição geral e aceita amplamente (SOARES, 2014, p. 82).

Para Soares (1998/2014, p. 36-40), letramento é como o "resultado da ação de 'letrar-se'; se dermos ao verbo 'letrar-se' o sentido de 'torna-se letrado”. Enfatiza que o adjetivo letrado/letrada em português tem o sentido de "caracterizar uma pessoa que além de saber ler e escrever, faz uso frequente e competente da leitura e escrita." Ou seja, aquele que "vive em estado de letramento, [...] que usa socialmente a leitura e a escrita, pratica a leitura e a escrita, responde adequadamente às demandas sociais de leitura e de escrita."

A autora explica que "letramento é o que as pessoas fazem com as habilidades e conhecimentos de leitura e escrita, em um contexto específico, e como essas habilidades se relacionam com as necessidades, os valores e as práticas sociais." (SOARES, 1998/2014, p. 72, itálico da autora). E continua dizendo que "é o conjunto de práticas sociais relacionadas à leitura e à escrita em que os indivíduos se envolvem em seu contexto social."

Soares (2002), acompanhando o desenvolvimento das tecnologias de comunicação eletrônica como o computador, a Internet e a Web, avança no sentido da atualização do conceito de letramento como um "estado ou condição do indivíduo ou de grupos sociais de sociedades letradas que exercem efetivamente as práticas sociais de leitura e escrita, participam competentemente de eventos de letramento." Soares (2002, p. 145). Reitera a existência de diversos letramentos, posto que existem diferentes efeitos (sociais, cognitivos e discursivos) das tecnologias (tipográfica e digital), com seus "mecanismos de produção, reprodução e difusão da escrita."

Chama a atenção para a importância de se "captar o estado ou condição" que instituem as práticas de leitura e de escrita com as tecnologias digitais, destacando ser um momento privilegiado para identificar se tais práticas, "o letramento na cibercultura, conduzem a um estado ou condição diferente daquele a que conduzem as práticas de leitura e de escrita quirográficas e tipográficas [...]." (SOARES, 2002, p. 146).

Ela destaca ainda que a escrita na tela possibilita a criação de hipertextos, pois compreende a tela como:

[...] novo espaço de escrita, traz significativas mudanças nas formas de interação entre escritor e leitor, entre escritor e texto, entre leitor e texto e até mesmo, mais amplamente, entre o ser humano e o conhecimento. [...] a hipótese é de que essas mudanças tenham consequências sociais, cognitivas 
e discursivas, e estejam, assim, configurando um Letramento Digital [...] (SOARES, 2002, p. 151).

Portanto, concebe o Letramento Digital como:

[...] um certo estado ou condição que adquirem os que se apropriam da nova tecnologia digital e exercem práticas de leitura e de escrita na tela, diferente do estado ou condição - do letramento - dos que exercem práticas de leitura e de escrita no papel. (SOARES, 2002, p. 151, itálico da autora).

Assim como no cenário internacional, na produção acadêmica nacional, a heterogeneidade conceitual é mencionada desde a tradução do termo na década de 1980. E com a incursão maciça das TDIC, novos termos relacionados ao Letramento emergiram e, com isso, a delimitação dos conceitos tornou-se mais controversa e complexa.

Os estudos expressivos sobre Letramento na presença das TDIC datam de meados dos anos 2000 e, desde então, existe uma discussão abundante.

Buzato (2006) prefere usar o plural, letramentos e propõe uma definição de Letramentos Digitais como:

[...] conjuntos de letramentos (práticas sociais) que se apóiam, entrelaçam, e apropriam mútua e continuamente por meio de dispositivos digitais para finalidades específicas, tanto em contextos socioculturais geograficamente e temporalmente limitados, quanto naqueles construídos pela interação mediada eletronicamente. (BUZATO, 2006, p. 16).

Coscarelli e Ribeiro (2007, p. 9) relacionam o Letramento Digital à prática de leitura e escrita, e o definem como a "ampliação do leque de possibilidades de contato com a escrita também em ambiente digital (tanto para ler quanto para escrever)."

Para Frade (2007, p. 60), o Letramento Digital implica "tanto a apropriação de uma tecnologia, quanto o exercício efetivo das práticas de escrita que circulam no meio digital."

Rojo (2009, p. 44) destaca a importância da discussão sobre os multiletramentos quanto à sua relevância para a democratização das culturas, linguagens, conteúdos e metodologias de ensino. A autora ressalta que para ler:

\footnotetext{
É preciso também compreender o que se lê, isto é, acionar o conhecimento de mundo para relacioná-lo com os temas do texto, inclusive o conhecimento de outros textos/discursos (intertextualizar), prever, hipotetizar, inferir, comparar informações, generalizar. É preciso também interpretar, criticar, dialogar, com o texto: contrapor a ele seu próprio ponto de vista, detectando o ponto de vista e a ideologia do autor, situando o texto em seu contexto. Reciprocamente, para escrever, não basta codificar e observar as normas da escrita [...] é também preciso textualizar: estabelecer relações e progressão de temas e ideias, providenciar coerência e coesão, articular o texto a partir de um ponto de vista [...] (ROJO, 2009, p. 44).
}

Rojo (2012, p. 13) explica que o conceito de Letramentos Múltiplos se difere do conceito de Multiletramentos. Afirma que os Letramentos (múltiplos) apontam "para a 
multiplicidade e variedade das práticas letradas, valorizadas ou não, nas sociedades em geral", enquanto o conceito de Multiletramentos constituem um arcabouço mais amplo e apontam:

[...] dois tipos específicos e importantes de multiplicidade presentes em nossas sociedades, principalmente urbanas, na contemporaneidade: a multiplicidade cultural das populações e a multiplicidade semiótica de constituição dos textos por meio dos quais ela se informa e se comunica. (ROJO, 2012, p. 13).

Xavier (2007, p. 2-4) declara que mesmo um indivíduo que já tenha dominado a tecnologia da leitura e da escrita em diversas práticas sociais e, portanto, possua letramento, pode ser um "iletrado digital”. Explica que o Letramento Digital pressupõe "mudanças nos modos de ler e escrever os códigos e sinais verbais e não-verbais", até em virtude do suporte - a tela (digital), diferente do suporte impresso. Mas para além da diferença do suporte, o autor ressalta que deve haver uma mudança nos modos de praticar a leitura e a escrita, e para tanto são necessárias "abordagens pedagógicas que ultrapassem os limites físicos das instituições de ensino."

Os usuários da Internet assumem os papéis de autores e leitores de textos. Além disso, a Internet e os hipertextos escolhidos por meio dos links "parecem viabilizar uma forma de aprendizagem ideal que se baseia no contexto e no modo natural como ela se dá." (XAVIER, 2007, p. 7).

O autor considera que é preciso uma mudança nas práticas pedagógicas e no perfil do professor para acompanhar os alunos em suas necessidades de saber. $O$ professor deve assumir o papel de "pesquisador", "articulador do saber", "gestor de aprendizagens", "consultor" e "motivador da aprendizagem por descoberta", rompendo com práticas bancárias e autoritárias (XAVIER, 2007, p. 3).

Xavier (2007) argumenta que, fora do contexto escolar, os estudantes como usuários das TDIC aprendem de modo independente e "estão se auto letrando pela Internet", o que desafia os sistemas educacionais e propõe um "jeito novo de aprender." (XAVIER, 2007, p. 3).

O uso diversificado e metafórico do termo letramento (ou alfabetização) é frequente na sociedade em geral, pois é usado como uma extensão do sentido do letramento alfabético aplicado a outra área ou objeto, com sentido de competência, como por exemplo: letramento musical, letramento ambiental, letramento cultural. $E$ com as expressões Letramento Digital ou Alfabetização Digital a metáfora se justifica, de acordo com Pérez Tornero (2004, p. 50), por envolver processos de aprendizagem na "aquisição de uma linguagem particular." 
Cerutti-Rizzatti (2012, p. 292-294), ao discutir os "alargamentos e circunscrições das fronteiras do conceito de letramento", enfatiza que o estudo sobre o fenômeno do letramento é vinculado a "questões de cidadania, de identidade cultural, de mobilidade social" e chama a atenção para a "expansão desmedida" do uso do termo em "instâncias diversas em que o signo verbal escrito não esteja presente ou não seja prevalecente", já que letramento requer necessariamente a "presença da língua escrita." Por isso, chega a sugerir a necessidade de revisão do uso do termo Letramento Digital, "dado que as mídias digitais, por sua natureza configuracional, não se constituem de signos verbais escritos tão somente, revelando uma dimensão semiótica mais ampla."

A aproximação teórica com o significado de Letramento Digital, por um lado, permitiu à pesquisadora compreender certas imprecisões e indefinições terminológicas, e, por outro, possibilitou à interpretação pessoal, construída no decorrer da pesquisa, maior clareza no tema.

Nesse cenário de múltiplos significados em torno do Letramento Digital, termo em uso corrente no Brasil, o conceito de Freitas (2010) expressa a sua amplitude, significando:

[...] o conjunto de competências necessárias para que um indivíduo entenda e use a informação de maneira crítica e estratégica, em formatos múltiplos, vinda de variadas fontes e apresentada por meio de computador-internet, sendo capaz de atingir seus objetivos, muitas vezes compartilhado social e culturalmente. (FREITAS, 2010, p. 339).

Em sua representação, a autora faz alusão às competências (informacionais, multimidiáticas, computacionais e comunicacionais), aos objetivos, explicita a tecnologia como um meio, e considera as dimensões pessoal, social e cultural presentes na comunicação e informação.

A existência de múltiplos significados para as práticas de Letramento Digital parece apontar para a necessidade de pesquisas sobre o tema quando se trata da apropriação do conceito no contexto escolar. Os estudos poderão contribuir para a produção e ampliação de conhecimento na área, produção de recursos didáticos, práticas efetivas nas escolas e ainda oferecer informações relevantes para subsidiar cientificamente iniciativas governamentais para inclusão das TDIC.

Com esse entendimento a Seção 1.3 apresenta o conhecimento dos Programas do Governo Federal, que se relacionam à incorporação das TDIC na Educação Básica e resultados de pesquisas nacionais, que relataram a presença nas escolas brasileiras. 


\subsection{PROGRAMAS E PESQUISAS NACIONAIS E O LETRAMENTO DIGITAL}

O Letramento Digital escolar não se constitui apenas a partir da clareza de seus significados, mesmo com as transformações na sua construção conceitual e os desdobramentos teóricos até aqui identificados.

O fenômeno do Letramento Digital tem se configurado como um grande desafio para a Educação Escolar. As condições favoráveis à incorporação das TDIC requerem investimento na infraestrutura física e tecnológica, na formação de professores e dos demais agentes da escola, além de outros fatores.

Observando-se que a anunciada "inclusão digital como possibilidade de inclusão social vai além do acesso ao aparato tecnológico [...]" e que "o uso de computadores, habilidade imprescindível para a formação dos alunos, deve ser entendido como forma de letramento voltado para o protagonismo e o exercício da cidadania." (PIMENTA; PEREIRA, 2012, p. 9), a escola precisa ter computadores suficientes, atualizados e com manutenção permanente e receber formação adequada e permanente por parte dos seus mantenedores.

É fato que, com o advento da Internet no Brasil na década de 1980, muitas iniciativas de inclusão das tecnologias nas escolas públicas foram empreendidas pelo MEC. E foi nessa década que surgiram as primeiras iniciativas governamentais voltadas para uma política nacional de informatização da educação, com o Projeto Educom.

O Projeto Educom, iniciado em 1985, era focado nos equipamentos, nas linguagens e na capacitação técnica para a Informática. Passou por avaliações e aprimoramentos ao longo dos anos, como o Programa de Ação Imediata em Informática na Educação de $1^{\circ}$ e $2^{\circ}$ graus, aprovado em 1986 , que teve como objetivo elaborar uma nova política para desenvolver infraestrutura de suporte às secretarias estaduais de educação, capacitação de professores, produção de software educativo e integração de pesquisas de universidades brasileiras (BRASIL, 1994).

Em outubro de 1989, o Projeto Educom foi substituído pelo Programa Nacional de Informática Educativa (Proninfe), com a finalidade de capacitar professores, técnicos e pesquisadores em Informática, de forma contínua e permanente, para atender e enriquecer estratégias pedagógicas (BRASIL, 1994).

Em 1997, o Programa Nacional de Informática na Educação (Proinfo) substituiu o Proninfe e, como política pública, teve por finalidade "disseminar o uso pedagógico 
das tecnologias de informática e telecomunicações nas escolas públicas de ensino fundamental e médio pertencentes às redes estadual e municipal." (BRASIL, 1997b). Foram organizadas unidades de ensino profissionalizante, com a finalidade de proporcionar a educação continuada; incentivar, articular e promover o desenvolvimento de empreendedorismo com a capacitação e atualização tecnológica gerencial, mediante ampliação de pontos de acesso ao conhecimento em ciência e tecnologia. Esse programa articulou-se com outras iniciativas governamentais, como o Programa Banda Larga nas Escolas (PBLE), o Projeto Um Computador por Aluno (UCA), dentre outros (BRASIL, 2018a).

Em dezembro de 2007, o Proinfo passou por uma reestruturação, ampliando a meta de inclusão digital. Foi renomeado como Programa Nacional de Tecnologia Educacional (Prolnfo Integrado) voltado para a educação escolar, aliando a distribuição de equipamentos tecnológicos, formação e oferta de conteúdos e recursos educacionais digitais, conforme Brasil (2007, 2018b).

O Projeto UCA, criado em $2007^{17}$, foi implantado com uma experiência piloto nos estados do Tocantins, São Paulo, Rio de Janeiro, Rio Grande do Sul e Distrito Federal com o objetivo de intensificar as Tecnologias de Informação e Comunicação nas escolas, por meio da distribuição de computadores portáteis aos alunos da rede pública de ensino, contemplando Laboratórios de Informática, produção e disponibilização de objetos educacionais (BRASIL, 2008d).

Em junho de 2010, foi estendido para escolas públicas (redes federal, estadual, distrital e municipal) e escolas sem fins lucrativos, que atendiam a pessoas com deficiência, como Programa Um Computador por Aluno (Prouca), visando a inclusão digital, com equipamentos de informática, software, suporte e assistência técnica, como definido em legislação específica (BRASIL, 2010b, 2018a).

O PBLE foi lançado abril de 2008 para incrementar o ensino público no Brasil, a partir da conexão à Internet de todas as escolas públicas urbanas, mediante "tecnologias que propiciem qualidade, velocidade e serviços" (BRASIL, 2008a, 2008c, 2018a).

\footnotetext{
17 A Profa. Dra. Stela C Bertholo Piconez (FE/USP), orientadora desta investigação participou como membro efetivo do GT-UCA junto aos professores Prof. Dr. José Armando Valente (UNICAMP); Profa. Dra. Léa Fagundes (UFRS); Profa. Dra. Maria Elizabeth B de Almeida (PUCSP); Prof. Dr. Mauro Cavalcante Pequeno (UFC); Prof. Dr. Paulo Gileno Cysneiros (UFPE) e Prof. Dr. Simão Pedro Pinto Marinho (PUCMG), dentre outros (PICONEZ, 2017).
} 
$\mathrm{Na}$ sequência, outros mecanismos de apoio à Educação Escolar, incluindo a formação de professores são oferecidas pelo MEC, como o Salto para o Futuro, a TV Escola, o Portal Domínio Público, o Portal do Professor, o Banco Internacional de Objetos Educacionais (BIOE) e o Guia de Tecnologias (BRASIL, 2018a).

O Salto para o Futuro, datado de 1991, discute em sua programação a educação brasileira, políticas públicas na área e o dia a dia de professores e alunos. Utiliza diversas mídias, como a TV Escola, telefone, smartphone, site com publicação eletrônica, fórum e e-mail (BRASIL, 2018a).

A TV Escola foi criada em 1996 para servir aos professores em suas práticas de ensino e formação. Está disponível aos interessados em educação e em sua própria aprendizagem. Utiliza Plataforma de comunicação em TV (satélite aberto analógico e digital), Internet e o Aplicativo TV Escola (BRASIL, 2018a).

Domínio Público, um portal Biblioteca Virtual, implantado em 2004, disponibiliza aos professores, estudantes e público em geral fotos, textos, obras artísticas, literárias e científicas de domínio público, compartilhadas gratuitamente (BRASIL, 2018a).

Portal do Professor, criado em 2008, é um ambiente virtual que veicula conteúdos curriculares em recursos educacionais, em parceria com o Ministério da Ciência e Tecnologia (MCT), com o objetivo de "apoiar a formação docente e enriquecer a sua prática pedagógica nas escolas brasileiras" (BRASIL, 2008b, 2018a).

O BIOE é um repositório de objetos educacionais em diversos formatos que foi construído a partir de 2008 para disponibilizar conteúdos de todos os níveis de ensino com acesso público (BRASIL, 2018a).

O Guia de Tecnologias MEC nas edições 2009, 2011-2012, 2013 é oferecido aos gestores educacionais de escolas públicas brasileiras para auxiliar na aquisição de materiais e tecnologias (BRASIL, 2009, 2011, 2013b, 2018a).

Mais recentemente, o MEC disponibilizou ${ }^{18}$ gratuitamente para smartphones iOS e Android os aplicativos e-Proinfo, Mosquito Ação, Prouni, Sisu, IsF Aluno, IsF Gestão, TV Escola, TV INES, que oferecem informações e consultas sobre seus programas e serviços, proporcionam informações de instituições, cursos, participação em fóruns de discussão, jogo educativo, entretenimento, dentre outros (BRASIL, 2018a).

O MEC além de mencionar que considera importante a utilização de tecnologias na escola, alerta para a necessidade do seu uso com sentido, tendo em vista o

\footnotetext{
${ }^{18}$ Disponível em: <http://portal.mec.gov.br/>.
} 
compromisso com o "desenvolvimento humano, com a formação de cidadãos, com a gestão democrática, com o respeito à profissão do professor e com a qualidade social da educação." (BRASIL, 2013b, p. 10). Adverte que essa qualidade não está garantida com o uso de tecnologias, posto que este deve estar alinhada aos fins educacionais, com a proposta pedagógica da rede de ensino e da escola, e assim como as demais tecnologias (giz, livro, rádio, TV), o uso das TDIC deve "possibilitar que a interatividade virtual se desenvolva de modo mais intenso, inclusive na produção de linguagens." (BRASIL, 2013a, p. 25).

Contudo, tais iniciativas não atenderam todas as escolas públicas brasileiras, tampouco cumpriram a missão da inclusão digital no meio escolar integralmente. Pesquisas recentes como o Censo Escolar da Educação Básica ${ }^{19}$, do Instituto Nacional de Estudos e Pesquisas Educacionais Anísio Teixeira (INEP); TIC Educação 2016 20 , do Cetic.br; e estudos ${ }^{21}$ do Cieb revelam condições de escolas brasileiras e oferecem informações importantes para avaliação e planejamento nessa área (INEP, 2017; CIEB, 2016b; CGI.br, 2017).

Em 2016, os dados do Censo Escolar da Educação Básica apontam que a possibilidade de uso de computadores na escola brasileira é uma questão não resolvida, já que no País é real a existência de escolas sem Laboratórios de Informática e sem energia elétrica, inclusive na zona urbana. De acordo com o Censo, havia Laboratório de Informática somente em 44,7\% das escolas de Ensino Fundamental, anos iniciais e, em $62,8 \%$ das escolas de anos finais; e no Ensino Médio, em 82,7\% das escolas; a energia elétrica estava disponível apenas em 97\% das escolas de Educação Básica (INEP, 2017).

A Pesquisa TIC Educação 2016 constatou que, decorrido 20 anos da implementação do Proinfo, "ainda há desafios a serem vencidos quanto ao acesso a equipamentos TIC e à conexão à Internet que estão disponíveis para uso pedagógico." (CGI.br, 2017).

Quanto à capacitação docente para uso das tecnologias, a Pesquisa TIC Educação 2016 mostrou que 70\% dos professores não fizeram cursos de capacitação para uso de computador e Internet em atividade de ensino. Dos que fizeram, apenas

19 A Pesquisa 2016 (dados referentes à última quarta-feira de maio) abrangeu 186,1 mil escolas (INEP, 2017).

20 O Cetic.br pesquisou entre os meses de agosto a dezembro de 2016. Coletou dados de 1.106 escolas, 1.854 professores e 11.067 alunos ( $5^{\circ}$ e $9^{\circ}$ anos do Ensino Fundamental e $2^{\circ}$ ano do Ensino Médio), além de 935 diretores e 922 coordenadores pedagógicos (CGI.br, 2017).

21 O Guia Edutec 2016 pesquisou em setembro e dezembro de 2016, 12.898 escolas em 14 estados de todas as regiões do Brasil e Distrito Federal (CIEB, 2016b). 
para $15 \%$ a capacitação foi oferecida pelo governo ou secretarias de educação (CGI.br, 2017).

Segundo o CGI.br (2017), em 2016, estava universalizada a presença de pelo ao menos um tipo de computador (de mesa, portátil ou tablete) nas escolas públicas na área urbana; 95\% dessas escolas possuíam acesso à Internet ao menos em um computador; e a velocidade da conexão era de até $4 \mathrm{Mbps}$, para 78\% dessas escolas.

Embora tenha havido crescimento nos últimos anos do uso do computador e Internet nos domicílios (CGI.br, 2015a), a Pesquisa TIC Educação 2014 indicou que o uso na escola é limitado, permanecendo o desafio a ser enfrentado pelas políticas públicas, inclusive no que diz respeito à formação do professor (CGI.br, 2015b).

Dellagnelo (2017), ao analisar o histórico das políticas de inovação e tecnologia educacional no Brasil, observa a existência de contradições. Uma delas é o fato de que o País participou na vanguarda de projetos de uso de tecnologia na educação no início da década de 1980, e em 2017, a política ainda vigente para promover o uso pedagógico das TIC na rede pública de Ensino Fundamental e Médio era o Proinfo.

Como as questões de várias ordens concorrem para essa situação, dentre elas razões políticas, financeiras, geográficas e até pedagógicas, é sabido que as escolas precisam ser estruturadas; entretanto não basta serem equipadas com computadores, Laboratórios de Informática e aplicativos de última geração.

\begin{abstract}
É necessário repensar a questão da dimensão do espaço e do tempo da escola. A sala de aula deve deixar de ser o lugar das carteiras enfileiradas para se tornar um local em que professor e alunos podem realizar um trabalho diversificado em relação a conhecimento e interesse. O papel do professor deixa de ser o de 'entregador' de informação para ser o de facilitador do processo de aprendizagem. O aluno deixa de ser passivo, de ser o receptáculo das informações para ser ativo aprendiz, construtor do seu conhecimento. (VALENTE; ALMEIDA, 1997, p. 15).
\end{abstract}

Segundo Dellagnelo (2017), países como Cingapura, Coreia do Sul e Estônia, que utilizaram eficazmente inovação e tecnologia para a melhoria da qualidade e equidade na educação pública, adotaram algumas medidas em comum, envolvendo fatores humanos e infraestrutura, a longo prazo, com revisões periódicas de metas e resultados, quais sejam:

[...] elaboração das políticas nacionais de inovação e tecnologia a partir de uma visão compartilhada e convergente com as políticas de desenvolvimento econômico e social do país, [...] coordenação da participação de diferentes atores e instituições na implementação da política [...] e planejamento multidimensional [...] (DELLAGNELO, 2017, p. 33).

A partir da compreensão dessa relação bem-sucedida de multidimensionalidade e de sucesso de políticas de inovação e tecnologia, surgiu na Holanda, em 2001, a 
Teoria Four in balance, com pesquisadores da atual Fundação Kennisnet, à época Fundação TIC para a Escola.

No Brasil essa teoria foi traduzida como “Teoria das Quatro Dimensões”, cujo teor se expressa no planejamento e implementação de ações integradas por dois elementos, cada um em duas dimensões: humano (visão e competências); tecnológico (conteúdos, recursos digitais e infraestrutura) (CIEB, 2016a, 2016b; DELLAGNELO, 2017).

A Teoria indica que os quatro eixos devem estar equilibrados para que o uso das TDIC seja eficaz, orientado e controlado, para isso,

[...] cabe ao poder público garantir que a escola tenha as informações que os alunos necessitam, criar condições para que tenham projetos pedagógicos adequados à sua realidade e possam estruturar os processos de ensino e aprendizagem de forma mais eficiente e melhorar a transparência das atividades para os pais e para a sociedade. (CIEB, 2016a, p. 31).

Essa Teoria tem sido adotada no Brasil pelo Cieb, em seus estudos de análise e proposição de políticas públicas para inovação e tecnologias na educação pública no País.

Em pesquisa realizada, o Cieb (2016b) identificou as condições das dimensões analisadas e revelou que além de desequilíbrio entre os estados brasileiros, há desequilíbrio em um mesmo estado, o que pode ser explicado "pelo caráter episódico e fragmentado das políticas nacionais de tecnologias educacional, mas também pela priorização aleatória de investimentos feitos pelas redes estaduais", analisa Dellagnelo (2017, p. 38).

O MEC reconhece que a tecnologia tenha se revelado como "instrumento eficaz para conquistar equidade no acesso ao estudo, contemporaneidade no aprendizado e melhorias na gestão das redes educacionais" (BRASIL, 2017c), e que o Brasil precisa, na área da Educação, de um novo e efetivo programa de inovação e, por isso, lançou, em novembro de 2017, o Programa de Inovação Educação Conectada, inspirado em experiências internacionais bem-sucedidas, como a Teoria das Quatro Dimensões, adotando como pilares desse novo Programa as dimensões: visão, competências, recursos educacionais e infraestrutura (BRASIL, 2017a).

A adoção da Teoria das Quatro Dimensões no último Programa do MEC (BRASIL, 2017a) sinaliza avanço na compreensão teórica para intervenção prática na problemática do uso das TDIC na escola brasileira, e se encaminha em direção às condições necessárias ao Letramento Digital na Educação formal, que para se 
desenvolver requer o equilíbrio da visão, competências, recursos educacionais e infraestrutura.

Recentemente, a Base Nacional Comum Curricular (BNCC), aprovada em dezembro de 2017, explicita o compromisso da educação brasileira, fundamentado nas Diretrizes Curriculares Nacionais da Educação Básica (DCN), visando a "formação humana integral e à construção de uma sociedade justa, democrática e inclusiva." (BRASIL, 2017b, p. 7). Para tanto, a BNCC define um conjunto de dez competências a serem desenvolvidas ao longo da Educação Básica, de forma integrada aos componentes curriculares, dentre as quais, três delas estimam aspectos relacionados às TDIC, como: os conhecimentos construídos sobre o mundo digital; a linguagem digital para expressão e compartilhamento de saberes; e, a utilização das TDIC de forma crítica, reflexiva, significativa e ética.

Este capítulo não abrangeu toda a discussão sobre a evolução conceitual do letramento, tampouco sobre as iniciativas governamentais para inclusão digital escolar. No entanto, foi fundamental perceber o movimento no processo de compreensão do letramento (alfabético e digital) e da inserção das TDIC nas escolas.

Foi relevante compreender que existe uma relação necessária entre os letramentos (alfabético e digital) - o alfabético serve de apoio ao digital (XAVIER, 2007), sendo ambos essenciais à leitura crítica dos dados e informações disponíveis na Web, a fim de transformá-los em conhecimento para atuar na conquista da cidadania na sociedade contemporânea, dadas as inovações tecnológicas e exigências socioeconômicas.

A leitura sobre os conceitos de letramento mostrou sua relevância e abrangência. No entanto, constatou-se que para maior compreensão é importante considerá-lo não apenas como apreensão linguística e com um fim em si mesmo.

O Letramento Digital, considerado ato social, tem sido estudado em sua capacidade de auxiliar alunos em suas escolhas e na inserção a novos modos de acesso à informação e de produção de conhecimentos.

Empreender um olhar reflexivo sobre o Letramento Digital, com a finalidade de compreender seu universo, implica investigar no contexto da formação dos professores (no local de trabalho) como ocorre a apropriação tecnológica. Esta não se reduz ao uso técnico de equipamentos e aplicativos, mas certamente transcende essa dimensão. 
Diante do exposto e da pluralidade cultural e da produção acadêmica revisada (Seção 2.1) foram ampliadas as reflexões sobre suas influências, na imersão da realidade escolar, "a mais importante agência de letramento da sociedade." (KLEIMAN, 2005, p. 38), para a qual a Seção 2.2 apresenta a configuração da pesquisa efetivada no contexto do Ensino Fundamental II. 


\section{LETRAMENTO DIGITAL: REVISÃO DE ESTUdOS E A TRAJETÓRIA METODOLÓGICA}

Este Capítulo apresenta o tratamento metodológico conferido à investigação em duas dimensões: a revisão de estudos, que ampliou o entendimento do Letramento Digital na produção acadêmica nacional e internacional; e a dimensão empírica, com imersão na prática escolar, que ocorreu no contexto do Ensino Fundamental II (anos finais) em uma instituição localizada na Região Metropolitana de São Paulo, no município de Cotia - a Escola Estadual Fernando Nobre.

Inicialmente, a Seção 2.1 descreve os resultados da revisão de estudos realizada em teses e dissertações e, na sequência, os artigos em periódicos. $\mathrm{Na}$ Seção 2.2 apresenta a configuração da pesquisa; descreve seus procedimentos de coleta, de organização e interpretação dos dados e, finalmente, apresenta as estratégias de implementação nas Oficinas de Orientação de Estudos da escola.

\subsection{LETRAMENTO DIGITAL NA PRODUÇÃO ACADÊMICA}

Esta Seção aborda como o tema Letramento Digital vem sendo tratado pela produção acadêmica, no âmbito do Ensino Fundamental. O percurso conferiu maior familiaridade com o objeto da pesquisa, orientando a compreensão dos dados coletados.

Para o mapeamento das referências foi estabelecido como marco temporal o ano 2008, o que se justifica pela repercussão do Projeto "Padrões de Competência em TIC para Professores", em sua versão original em 2008, cujos documentos a têm fomentado debates sobre a capacitação de professores para o uso das tecnologias em sala de aula (UNESCO, 2009a, 2009b). O mapeamento teve como foco investigar as tendências sobre a temática, no âmbito do Ensino Fundamental II, etapa que compreende do $6^{\circ}$ ao $9^{\circ}$ ano (10-11 aos 13-14 anos de idade).

$\mathrm{O}$ acesso às teses e dissertações ocorreu a partir das bases ${ }^{22}$ : Biblioteca Digital Brasileira de Teses e Dissertações do Instituto Brasileiro de Informação em Ciência e 
Tecnologia - BDTD.IBICT (2002); Biblioteca Digital de Teses e Dissertações da Universidade de São Paulo - BDTD.USP (2001); e Catálogo de Teses e Dissertações da Coordenação de Aperfeiçoamento de Pessoal de Nível Superior - CT.Capes (2002).

Para realização da busca de artigos científicos em periódicos foram consideradas duas bases ${ }^{23}$ de dados de acesso livre, indicadas na página da Biblioteca da FE/USP e que indexam periódicos brasileiros e de outros países, em diversas áreas: Red de Revistas Científicas de América Latina y el Caribe, España y Portugal - Redalyc (2003) e Scientific Electronic Library Online - SciELO (1998).

Para a busca nas bases de dados das produções científicas foram utilizados os descritores "Letramento Digital" e "Ensino Fundamental", com emprego dos operadores booleanos "and" "e "or", e as variações nos idiomas inglês (elementary and middle school) e espanhol (primaria y secundaria).

O mapeamento considerou os seguintes dados: ano de publicação, instituição de origem, estado, país, autor, título, grande área e área de conhecimento, modalidade da produção, programa da pós-graduação strictu sensu ou o periódico.

Para efeitos estatísticos, a contagem de trabalhos repetidos em várias bases, o item em duplicidade foi considerado apenas uma vez.

Para o conhecimento exploratório da temática, além dos dados de caracterização já mencionados, foi realizada leitura prévia de resumos das produções; na sequência, procedeu-se a leitura pormenorizada dos trabalhos para identificação dos seguintes aspectos: bases teóricas principais, metodologia (abordagem, procedimentos, técnicas e participantes), campo de atuação (setor de aplicação e nível de ensino), contexto da investigação (ensino, aprendizagem, formação de professores etc.), foco de interesse (resultados esperados, competências pesquisadas etc.).

A seleção dos trabalhos com interesse para esta investigação se deu obedecendo aos seguintes critérios:

a) área de conhecimento - Ciências Humanas/Educação;

b) delimitação do campo de atuação - Ensino Fundamental II;

${ }^{23}$ Disponíveis em: <http://www.redalyc.org>; <http://www.scielo.org>. 
c) contexto da investigação - estudos que envolvem professores e alunos como participantes da pesquisa no processo de ensino-aprendizagem e formação docente na prática escolar, preferencialmente;

d) abordagem do objeto - atenção ao uso didático-pedagógico de TDIC, preferencialmente.

O tratamento dos critérios permitiu o mapeamento das produções, o que favoreceu o trabalho das análises quantitativas e qualitativas das obras selecionadas.

$O$ registro da revisão de estudos inicialmente faz referência às teses e dissertações, e em seguida, aos artigos em periódicos nacionais e internacionais.

\subsubsection{Teses e dissertações}

$\mathrm{Na}$ busca inicial com o descritor "Letramento Digital" foram localizados 204 trabalhos na BDTD.IBICT; no CT.Capes foram 316; e na BDTD.USP, um total de 15 (Tabela 2.1).

Tabela 2.1 - Número de teses e dissertações, segundo o descritor, por Base de dados (2008-2017)

\begin{tabular}{l|r|r|r}
\hline \multirow{2}{*}{ Descritor } & \multicolumn{3}{c}{ Base } \\
\cline { 2 - 4 } & IBICT & Capes & USP \\
\hline Letramento Digital & 204 & 316 & 15 \\
Letramento Digital e Ensino Fundamental & 35 & 43 & 2 \\
\hline Fonte: BDTD.IBICT, CT.Capes e BDTD.USP $(2016,2018)$ & &
\end{tabular}

Com o refinamento da busca por "Letramento Digital" e "Ensino Fundamental" foram encontrados um total de 80 trabalhos (Tabela 2.2.)

Tabela 2.2 - Número de teses e dissertações em Letramento Digital no Ensino Fundamental, segundo a Grande área, por Base de dados (2008-2017)

\begin{tabular}{l|r|r|r|r}
\hline \multirow{2}{*}{$\begin{array}{c}\text { Grande área de } \\
\text { conhecimento }\end{array}$} & \multicolumn{3}{|c|}{ Base } & \multirow{2}{*}{ Total } \\
\cline { 2 - 4 } & IBICT & Capes & USP & \\
\hline Linguística, Letras e Artes & 23 & 24 & 2 & 49 \\
Ciências Humanas & 10 & 12 & - & 22 \\
Outras áreas & 2 & 7 & - & 9 \\
\hline Total & 35 & 43 & 2 & 80 \\
\hline Fonte: BDTD.IBICT, CT.Capes e BDTD.USP $(2016,2018)$
\end{tabular}


Dos 80 trabalhos no Ensino Fundamental, 22 deles (27,5\%) estão ligados à Grande área das Ciências Humanas, na área de Educação (APÊNDICE A, Quadro 2.1).

$\mathrm{Na}$ Grande área de Linguística, Letras e Artes foram contabilizadas 49 produções, correspondendo a um maior índice de frequência, 61,25\% (APÊNDICE A, Quadro 2.2).

As áreas Multidisciplinar, Ciências Sociais Aplicadas e Outras áreas perfizeram um total de 9 produções, equivalente a 11,25\% (APÊNDICE A, Quadro 2.3).

A distribuição das teses e dissertações ao longo do período em análise revela que a média de produções anual nos primeiros cinco anos (2008 a 2012) foi de 2,2; e nos últimos cinco anos (2013 a 2017) foi de 13,8, correspondendo a um aumento de $72,5 \%$ de produções no período (Tabela 2.3 ).

Tabela 2.3 - Número de teses e dissertações - Letramento Digital/Ensino Fundamental, segundo o período de publicação, por Grande área (2008-2017)

\begin{tabular}{c|rcc|c|c}
\hline \multirow{2}{*}{ Período de Publicação } & \multicolumn{3}{|c|}{ Grande área } & \multirow{2}{*}{ Total } \\
\cline { 2 - 5 } & LLA & CH/EDU & Outras & \\
\hline $2008-2012$ & 6 & 5 & - & 11 \\
$2013-2017$ & 43 & 17 & 9 & 69 \\
\hline Total & 49 & 22 & 9 & 80 \\
\hline
\end{tabular}

Fonte: BDTD.IBICT, CT.Capes e BDTD.USP (2016, 2018)

LLA - Linguística, Letras e Artes; CH/EDU - Ciências Humanas/Educação

Os dados da Tabela 2.3 indicam crescente interesse pela temática do Letramento Digital no Ensino Fundamental nos programas de pós-graduação no País, e sobretudo nos anos finais, que foram campo de pesquisa em 64 trabalhos, nas diversas áreas, como ilustra a Tabela 2.4.

Tabela 2.4 - Número de teses e dissertações - Letramento Digital no Ensino Fundamental, segundo nível de ensino, por Grande área (2008-2017)

\begin{tabular}{c|r|c|c|c}
\hline \multirow{2}{*}{$\begin{array}{c}\text { Nível de Ensino } \\
\text { Fundamental }\end{array}$} & \multicolumn{3}{|c|}{ Grande área } & \multirow{2}{*}{ Total } \\
\cline { 2 - 4 } & LLA & CH/EDU & Outras & \\
\hline Ensino Fundamental I & 2 & 10 & 4 & 16 \\
Ensino Fundamental II & 47 & 12 & 5 & 64 \\
\hline Total & 49 & 22 & 9 & 80 \\
\hline Fonte: BDTD.IBICT, CT.Capes e BDTD.USP (2016, 2018)
\end{tabular}


É interessante inferir que, provavelmente a produção no Ensino Fundamental I (20\%), nível no qual os professores são pedagogos (atuam com letramento em seu sentido original de alfabetização) encontra-se em menor quantidade do que a produção no Ensino Fundamental II (80\%), uma vez que, neste nível, os professores são licenciados na área de Linguística, Letras e Artes, com aproximações teóricas ligadas às questões de gêneros de linguagem e comunicação.

Da leitura pormenorizada dos 80 trabalhos listados no APÊNDICE A, especificamente nas produções da área de Educação, que pesquisaram no Ensino Fundamental II, são destacados a seguir os aspectos (fundamentação teórica/autores; natureza das pesquisas; recursos e/ou aplicativos digitais; instituição de origem; região) pela proximidade do mesmo nível de ensino desta investigação. No conjunto desses trabalhos, em número de 12, foram encontradas duas teses e dez dissertações (Quadro 2.4).

Quadro 2.4 - Teses e Dissertações - Educação Ensino Fundamental II

\begin{tabular}{|c|c|c|}
\hline $\begin{array}{l}\text { Ano - Tipo } \\
\text { IES }\end{array}$ & Autor & Título \\
\hline $\begin{array}{l}2017-\mathrm{MA} \\
\text { UFPR (PR) }\end{array}$ & $\begin{array}{l}\text { Souza, Andréia Rabello } \\
\text { de }\end{array}$ & $\begin{array}{l}\text { O letramento digital no ensino da matemática sob a } \\
\text { perspectiva de complexidade }\end{array}$ \\
\hline $\begin{array}{l}2016-\text { MA } \\
\text { UNIVILLE (PR) }\end{array}$ & $\begin{array}{l}\text { Longarzo, Jussara } \\
\text { Cascaes }\end{array}$ & $\begin{array}{l}\text { Letramento digital na voz dos professores de língua } \\
\text { portuguesa dos anos finais do ensino fundamental }\end{array}$ \\
\hline $\begin{array}{l}2016-\mathrm{MA} \\
\text { UFU (MG) }\end{array}$ & Pires, Robson Miguel & $\begin{array}{l}\text { Letramento digital em livros didáticos de língua } \\
\text { portuguesa }\end{array}$ \\
\hline $\begin{array}{l}2016-\mathrm{MA} \\
\text { UNICAMP (SP) }\end{array}$ & Salcido, Alejandra Silva & $\begin{array}{l}\text { Linguagem escrita, habilidades metacognitivas e } \\
\text { tecnologia digital: uma relação em construção }\end{array}$ \\
\hline $\begin{array}{l}2015-\mathrm{MA} \\
\text { UFSC (SC) }\end{array}$ & $\begin{array}{l}\text { Cavicchioli, Gabriela } \\
\text { Spagnuolo }\end{array}$ & $\begin{array}{l}\text { As competências audiovisuais e os novos letramentos } \\
\text { na escola }\end{array}$ \\
\hline $\begin{array}{l}2014-\text { MP } \\
\text { IFSUL (RS) }\end{array}$ & $\begin{array}{l}\text { Mesck, Ana Paula de } \\
\text { Deus }\end{array}$ & $\begin{array}{l}\text { As perspectivas do professor de língua materna nos } \\
\text { anos finais do ensino fundamental a partir da } \\
\text { implantação do programa um computador por aluno } \\
\text { (PROUCA) }\end{array}$ \\
\hline $\begin{array}{l}2013-M A \\
\text { UFU (MG) }\end{array}$ & $\begin{array}{l}\text { Miranda, Guacira } \\
\text { Quirino }\end{array}$ & Crônicas animadas na educação digital \\
\hline $\begin{array}{l}2013-\mathrm{MA} \\
\text { UCS (RS) }\end{array}$ & Schonz, Mariane Maria & $\begin{array}{l}\text { O laptop educacional na sala de aula : movimentos } \\
\text { de letramento digital nas práticas de leitura e escrita de } \\
\text { estudantes do ensino fundamental }\end{array}$ \\
\hline $\begin{array}{l}2012-\text { MA } \\
\text { UEMG (MG) }\end{array}$ & $\begin{array}{l}\text { Ferreira, Jalmelice da } \\
\text { Luz }\end{array}$ & $\begin{array}{l}\text { Os usos das TICs no desenvolvimento da leitura e } \\
\text { escrita no ensino fundamental }\end{array}$ \\
\hline $\begin{array}{l}2012-\mathrm{DO} \\
\text { UFPE (PE) }\end{array}$ & $\begin{array}{l}\text { Silva, Ana Cristina } \\
\text { Barbosa da }\end{array}$ & $\begin{array}{l}\text { Softwares educativos: critérios de avaliação a partir } \\
\text { dos discursos da interface, da esfera comunicativa e do } \\
\text { objeto de ensino }\end{array}$ \\
\hline $\begin{array}{l}2011-\text { DO } \\
\text { UFPE (PE) }\end{array}$ & $\begin{array}{l}\text { Caiado, Roberta } \\
\text { Varginha Ramos }\end{array}$ & $\begin{array}{l}\text { Novas tecnologias digitais da informação e } \\
\text { comunicação e o ensino-aprendizagem de língua } \\
\text { portuguesa }\end{array}$ \\
\hline $\begin{array}{l}2010-M A \\
P \cup C \text { (MG) }\end{array}$ & $\begin{array}{l}\text { Velloso, Maria Jacy } \\
\text { Maia }\end{array}$ & $\begin{array}{l}\text { Letramento digital na escola: um estudo sobre a } \\
\text { apropriação das interfaces da Web } 2.0\end{array}$ \\
\hline
\end{tabular}

Legenda: MA - Mestrado acadêmico; MP - Mestrado Profissional; DO - Doutorado

Fonte: BDTD.IBICT e CT.Capes $(2016,2018)$ 
Um dos aspectos analisados nesses trabalhos refere-se aos pesquisadores que fundamentam os conceitos de Letramento e Letramento Digital. A maior incidência referencia os estudos de: Angela Kleiman; Antonio Carlos Xavier; Brian Street; Carla Coscarelli; Leda Tfouni; Magda Soares; Luís Antônio Marcuschi; Marcelo Buzato e Roxane Rojo.

Quanto à natureza das pesquisas foram encontradas abordagens qualitativas, como o estudo de caso e a pesquisa-ação. Esta última, com diversos formatos de intervenções, a saber: cursos, oficinas e produção de hipertextos em múltiplas modalidades (narrativas, crônicas, infográficos, memes e outros).

Quanto às tecnologias presentes nos procedimentos das pesquisas são referenciados: objetos de aprendizagem, redes sociais, blogs, softwares de animação, softwares educativos, Google Earth, dentre outros. E dentre os equipamentos eletrônicos envolvidos nos estudos, o laptop, computadores de mesa nas escolas e tablets.

É interessante notar que o maior número das produções se concentra na Região Sudeste e Sul do país, perfazendo um total de 83,3\%. Dentre as instituições em que foram desenvolvidas, $58,3 \%$ são universidades federais, $25 \%$ universidades particulares e $16,7 \%$ universidades estaduais.

Foram encontradas 83,3\% das produções em nível de Mestrado e apenas 16,7\% em nível de Doutorado. Estas últimas foram elaboradas na Região Nordeste e na mesma universidade, a UFPE.

Outra análise importante para esta investigação foi identificar que apenas três trabalhos abordam questões de formação docente, o que representa $25 \%$ desse quantitativo: Longarzo (2016), Mesck (2014) e a de Souza (2017).

Longarzo (2016), em "Letramento digital na voz dos professores de Língua Portuguesa dos anos finais do Ensino Fundamental”, pesquisa as concepções dos professores de Língua Portuguesa sobre a questão do Letramento Digital; Mesck (2014), em "As perspectivas do professor de língua materna nos anos finais do Ensino Fundamental a partir da implantação do Programa um computador por aluno (PROUCA)", investiga práticas e propostas didático-pedagógicas adotadas com o uso dos laptops, e Souza (2017), em "O Letramento Digital no ensino da Matemática sob a perspectiva de complexidade", analisa os reflexos do Letramento Digital, em um contexto de intervenção pedagógica, na prática docente de professores que ensinam Matemática. 
Dentre os trabalhos relacionados no Quadro 2.4, duas produções focalizam no livro didático: a tese "Novas tecnologias digitais da informação e comunicação e o ensino-aprendizagem de língua portuguesa", de Caiado (2011), analisa os conteúdos digitais presentes em livros didáticos e no processo pedagógico que envolve o discurso e práticas dos professores de Língua Portuguesa com TDIC; e a dissertação de Pires (2016), “Letramento Digital em livros didáticos de língua portuguesa”, analisa a contribuição dos livros didáticos de Língua Portuguesa para o Letramento Digital de alunos. Chama a atenção a distância de cinco anos entre elas e uma curiosidade, ou seja, o fato de investigar o Letramento Digital em livros didáticos, o que reflete de certa maneira, a complexidade dos conceitos de Letramento e seus desdobramentos.

Os estudos que denotam preocupação centrada nas tecnologias propriamente ditas, como softwares e audiovisuais na direção do desenvolvimento de leitura e escrita foram identificadas nas dissertações "As competências audiovisuais e os novos letramentos na escola", de Cavicchioli (2015), que investiga como os novos letramentos podem contribuir para o desenvolvimento de habilidades e competências audiovisuais dos alunos na escola; e na de Ferreira (2012), intitulada "Os usos das TICs no desenvolvimento da leitura e escrita no Ensino Fundamental", a qual analisa os usos das TIC relacionando-o ao conceito de Sociedade da Informação no desenvolvimento da leitura e escrita de alunos; e na tese de Silva (2012) "Softwares educativos: critérios de avaliação a partir dos discursos da interface, da esfera comunicativa e do objeto de ensino", que se dedica ao estudo de avaliação de softwares educativos de leitura e compreensão textual.

Miranda (2013), com as "Crônicas animadas na educação digital”, analisa a trajetória do Projeto Crônicas animadas e cultura digital, que atua com multiletramentos. Schonz (2013), com "O laptop educacional na sala de aula: movimentos de Letramento Digital nas práticas de leitura e escrita de estudantes do Ensino Fundamental", investiga como os movimentos de Letramento Digital ocorrem na sala de aula nas práticas de leitura e escrita de estudantes com uso de laptop.

Salcido (2016), em "Linguagem escrita, habilidades metacognitivas e tecnologia digital: uma relação em construção", analisa a produção escrita digital (blog) de alunos e as habilidades (meta) cognitivas envolvidas no processo de hipertextualidade.

Velloso (2010), em "Letramento Digital na escola: um estudo sobre a apropriação das interfaces da Web 2.0", pesquisa o processo de apropriação de interfaces da Web 2.0 e habilidades para o Letramento Digital discente, na qual 
observa a acelerada evolução e integração das diferentes tecnologias e aplicativos. Realizou uma pesquisa-ação e contou com a participação de duas professoras e do colaborador do Laboratório de Informática. Investigou se o processo de apropriação de interfaces da Web 2.0, orientado pela escola, confere habilidades para o Letramento Digital aos alunos do Ensino Fundamental. Com a coparticipação de uma das professoras, o pesquisador criou uma rede social virtual na Plataforma Ning para aprendizagem e produção de conteúdos das disciplinas de Ciências e Educação Física; e fez uso de sites para criação de histórias em quadrinhos, podcast, vídeo, dentre outras TDIC.

Baseada nas categorias de Warschaeur (2006), Veloso (2010) analisa os níveis de Letramento digital de alunos do $7^{\circ}$ ano, por meio de práticas sobre os conhecimentos e habilidades em relação aos recursos da Web 2.0 e verifica os movimentos de apropriação que se instituíam a partir dos usos das TDIC que utilizaram. Esse estudo constata significativa ampliação do uso do computador e da Internet por alunos; a interação entre professores e alunos ainda restrita aos espaços presenciais e tradicionais na escola; a motivação dos alunos atraídos pelo digital; as práticas de Letramento Digital (uso social das tecnologias digitais) já incorporadas pelos alunos, relacionadas à necessidade de comunicação, entretenimento e diversão. Constata um descompasso das práticas pedagógicas do Letramento Digital e o avanço da apropriação das tecnologias. Conclui que a escola pode promover situações que possibilitem maior fluência tecnológica e sugere a incorporação de práticas no ambiente virtual que favoreçam o Letramento Digital, para ampliar as oportunidades de comunicação e coautoria em interfaces da Web 2.0.

Longarzo (2016) analisa as concepções de Letramento Digital dos professores de Língua Portuguesa, da Rede Municipal de Ensino de Joinville (PR), com o aporte teórico de Angela Kleiman, Brian Street, Leda Tfouni, Magda Soares, Roxane Rojo e outros. Procedeu a análise de conteúdo do corpus de sua pesquisa, obtido nas respostas ao questionário (online e impresso) de oitenta professores e do aprofundamento das questões com oito deles, em entrevista semiestruturada.

Os resultados da pesquisa de Longarzo (2016) demonstram que as escolas eram carentes de infraestrutura adequada e que havia necessidade de maior oferta de formação de professores específica e dificuldades relacionadas à infraestrutura existente nas escolas, resultado este também contemplado como recomendações nos demais estudos. Cabe destaque ao aspecto descrito por Longarzo, relacionado aos 
equipamentos como os tablets, que eram utilizados como suporte para leitura e dicionário off-line, dadas as condições precárias não apenas de acesso à Internet; mas sobretudo porque as escolas brasileiras carecem de bibliotecas. Outro desafio identificado foi a utilização do tempo na formação docente nas escolas.

Os registros efetivados por essas pesquisas inferem a complexidade do tema e do grande desafio para a escola para incorporação das tecnologias digitais. Algumas produções destacam as dificuldades advindas da organização curricular (administrativa-pedagógica) e, especificamente, o estudo de Veloso (2010) reitera novas possibilidades de interação que podem contribuir para o desenvolvimento da coautoria no processo de ensino-aprendizagem.

A despeito dos estudos sobre Letramento Digital e do consenso de que ele deve estar inserido na formação dos cidadãos, existem dificuldades para sua implementação na Educação Básica. E sua superação não depende somente de iniciativas pelo contexto escolar descritos por algumas pesquisas. O desafio é complexo e implica esforço conjunto de toda equipe escolar, subsidiada por Políticas Públicas de Educação.

\subsubsection{Artigos em periódicos nacionais e internacionais}

A revisão dos estudos anteriores foi complementada com artigos encontrados em periódicos na área de Educação, que seguiu os mesmos critérios de seleção para as teses e dissertações (Seção 2.1). Na busca por produções no tema mais amplo Letramento foram localizados na Base Redalyc 135 artigos, e na SciELO, 25 (Tabela 2.5). Quando refinada a busca com os descritores "Letramento Digital" e "Ensino Fundamental" e os termos em inglês e espanhol, nenhuma produção foi encontrada na SciELO; e na coleção das 112 revistas indexadas na Redalyc, que envolvem questões da Educação, foram localizados 7 artigos (APÊNDICE A, Quadro 2.5).

Tabela 2.5 - Número de artigos em periódicos, segundo o descritor, por Base de dados (2008-2017)

\begin{tabular}{l|c|c}
\hline \multirow{2}{*}{ Descritores } & \multicolumn{2}{c}{ Base } \\
\cline { 2 - 3 } & Redalyc & SiELO \\
\hline Letramento Digital & 135 & 25 \\
Letramento Digital e Ensino Fundamental & 7 & - \\
\hline Fonte: Bases Redalyc, SiELO (2016, 2018) & \multicolumn{2}{|}{}
\end{tabular}


Feito o mapeamento e leitura dos 7 artigos, 42,8\% foram publicados em periódicos nacionais e $57,2 \%$, em internacionais. No conjunto de artigos, os que guardam proximidade com o foco desta investigação, foram as produções de Aguaded; Marín-Gutiérrez e Díaz-Parejo (2015), Fernández Morante; Cebreiro López e Fernández dela Iglesia (2011) e Sánchez Antolín; Muñoz Álvarez e Paredes Labra (2015) (Quadro 2.5).

Quadro 2.5 - Artigos - Educação/Ensino Fundamental II/equivalente

\begin{tabular}{|c|c|c|}
\hline $\begin{array}{c}\text { Ano, } \\
\text { Periódico }\end{array}$ & Autor & Título \\
\hline $\begin{array}{l}2016 \\
\text { Educação e } \\
\text { Pesquisa }\end{array}$ & $\begin{array}{l}\text { Ramírez García, Antonia; } \\
\text { Sánchez-Carrero, } \\
\text { Jacqueline; Contreras- } \\
\text { Pulido, Paloma }\end{array}$ & $\begin{array}{l}\text { La competencia mediática em educación primaria em el } \\
\text { contexto español }\end{array}$ \\
\hline $\begin{array}{l}2015 \\
\text { RIED }\end{array}$ & $\begin{array}{l}\text { Aguaded, Ignacio; Marín- } \\
\text { Gutiérrez Isidro; Díaz- } \\
\text { Parejo, Elane }\end{array}$ & $\begin{array}{l}\text { La alfabetización mediática entre estudiantes de } \\
\text { primaria y secundaria em Andalucía (España) }\end{array}$ \\
\hline \begin{tabular}{|l|}
2015 \\
Pixel-Bit. \\
Revista de \\
Medios y \\
Educación
\end{tabular} & $\begin{array}{l}\text { Sánchez Antolín, Pablo; } \\
\text { Muñoz Álvarez, Tania; } \\
\text { Paredes Labra, Joaquín; }\end{array}$ & $\begin{array}{l}\text { El trabajo em el aula y la competencia digital em el } \\
\text { modelo } 1^{\mathrm{a}} 1 \mathrm{de} \text { la comunidad de Madrid }\end{array}$ \\
\hline \begin{tabular}{|l}
2013 \\
Revista \\
Brasileira de \\
Linguística \\
Aplicada
\end{tabular} & $\begin{array}{l}\text { Saito, Fabiano Santos; } \\
\text { Ribeiro, Patrícia Nora de } \\
\text { Souza }\end{array}$ & $\begin{array}{l}\text { (Multi)letramento(s) digital(is) e teoria do } \\
\text { posicionamento: análise das práticas discursivas de } \\
\text { professoras que se relacionaram com as tecnologias da } \\
\text { informação e comunicação no ensino público }\end{array}$ \\
\hline \begin{tabular}{|l}
2013 \\
Educação. \\
Revista do \\
Centro de \\
Educação
\end{tabular} & $\begin{array}{l}\text { Valentini, Carla Beatris; } \\
\text { Cristina Maria Pescador; } \\
\text { Soares, Eliana Maria S. }\end{array}$ & $\begin{array}{l}\text { O laptop educacional na escola } \\
\text { pública: letramento digital e possibilidades de } \\
\text { transformação das práticas pedagógicas }\end{array}$ \\
\hline \begin{tabular}{|l|}
2012 \\
Revista de \\
Educación a \\
Distancia \\
\end{tabular} & $\begin{array}{l}\text { Monjelat, Natalia; } \\
\text { del Castillo, Héctor; Herrero, } \\
\text { David; García Varela, Ana } \\
\text { Belén; Miriam Checa }\end{array}$ & $\begin{array}{l}\text { Desarrollo de competencias a través de los videojuegos } \\
\text { deportivos: alfabetización digital e identidad }\end{array}$ \\
\hline $\begin{array}{l}2011 \\
\text { Pixel-Bit. } \\
\text { Revista de } \\
\text { Medios y } \\
\text { Educación }\end{array}$ & $\begin{array}{l}\text { Fernández Morante, } \\
\text { Carmen; Cebreiro López, } \\
\text { Beatriz; Fernández dela } \\
\text { Iglesia, Carmen }\end{array}$ & $\begin{array}{l}\text { Competencias para el aprendizaje em red de los } \\
\text { alumnos de educación secundaria em Galicia }\end{array}$ \\
\hline
\end{tabular}

Fonte: Base Redalyc $(2016,2018)$

Aguaded, Marín-Gutiérrez e Díaz-Parejo (2015), em “La alfabetización mediática entre estudiantes de primaria y secundaria em Andalucía (España)", tendo em vista preparar ações de formação midiática, analisam a competência midiática na dimensão tecnológica de estudantes em escolas públicas e privadas - primárias (9 a 12 anos) e secundárias (14 a 17 anos), em oito províncias da Comunidade Autónoma de 
Andalucia, na Espanha. A partir de entrevistas e aplicação de questionários online, identificaram as necessidades e carências na atuação escolar junto aos meios e tecnologias digitais. O estudo conclui que ambas as populações de estudantes apresentavam carências nas competências midiáticas na dimensão investigada. $O$ estudo, pioneiro na Espanha, aponta o desenvolvimento de conteúdos audiovisuais com competência midiática e sugere uma disciplina relacionada ao tema no currículo escolar.

Fernández Morante; Cebreiro López e Fernández dela Iglesia (2011), com as "Competencias para el aprendizaje em red de los alumnos de educación secundaria em Galicia”, analisam em caráter exploratório, níveis de competência, a partir da avaliação dos próprios alunos do nível secundário na Galícia, Espanha e de seus professores em questionários que abordam dimensões e competências tecnológicas necessárias na sociedade do conhecimento. Os autores apresentam a análise dos dados da dimensão trabalho em rede com as sub dimensões: navegação na Internet, busca e gestão de informação, comunicação e colaboração. Os resultados mostram níveis superiores de preparação nas competências instrumentais e insuficientes nas demais competências que se relacionam à aprendizagem autônoma e à construção de conhecimento. Apontam a necessidade de propostas de formação que melhorem a exploração e o uso de TIC para a otimização dos processos de aprendizagem.

Esses autores analisam as condições dos aspectos do Letramento Digital. No aspecto computacional, referido por eles como competências instrumentais, houve maior preparação dos alunos, uma vez que estes fazem uso pessoal e social de TDIC; e nos demais aspectos, que são requeridos na construção de conhecimento, apontam a insuficiência (letramento informacional, multimidiático e comunicacional).

Em outro artigo, o de Sánchez Antolín; Muñoz Álvarez e Paredes Labra (2015), denominado "El trabajo em el aula y la competência digital em el modelo 1 a 1 de la comunidad de Madri”, são apresentadas as análises realizadas sobre os tipos de atividades docentes e de competência digital incorporadas por estudantes de Centros de Educação secundária na Comunidade de Madri, que participaram do Programa Um computador por estudante. Trata-se de um estudo de caso, com adoção de entrevistas com professores, observações de aulas, aplicação de questionários e análise documental. Os autores observam diferentes processos de Letramento Digital nos projetos de professores participantes que usam TIC. Observam também a "resistência" ao uso das tecnologias e concluíram que o referido projeto ainda se 
encontra distante de ser uma atividade criativa e colaborativa possibilitada pelos dispositivos, com uma perspectiva mais ampla e orientada ao trabalho, o que acreditam ser uma condição para aquisição da competência digital desejada. Os autores chamam a atenção para o fato de que a criação e colaboração com suporte nas TDIC são variáveis essenciais no processo de aquisição de competências requeridas no processo de Letramento Digital.

Com a análise das produções revisadas foram identificados três aspectos quanto à concepção do tema, ao número de produções e aos resultados. Nos estudos revisados foi observado que não há consenso referente à concepção de Letramento Digital, ora compreendido como um processo, ora com o caráter de domínio no manuseio das TDIC, como produto.

O Mapa $^{24} 2.1$ representa graficamente a compreensão da pesquisadora no exercício de produzir uma síntese sobre o significado do Letramento Digital percebido nas produções acadêmicas revistas e distingue as duas posições identificadas nos trabalhos.

Mapa 2.1 - Dimensões do Letramento Digital na revisão de estudos

Pergunta focal: Como é compreendido o Letramento Digital nas produções acadêmicas revisadas?

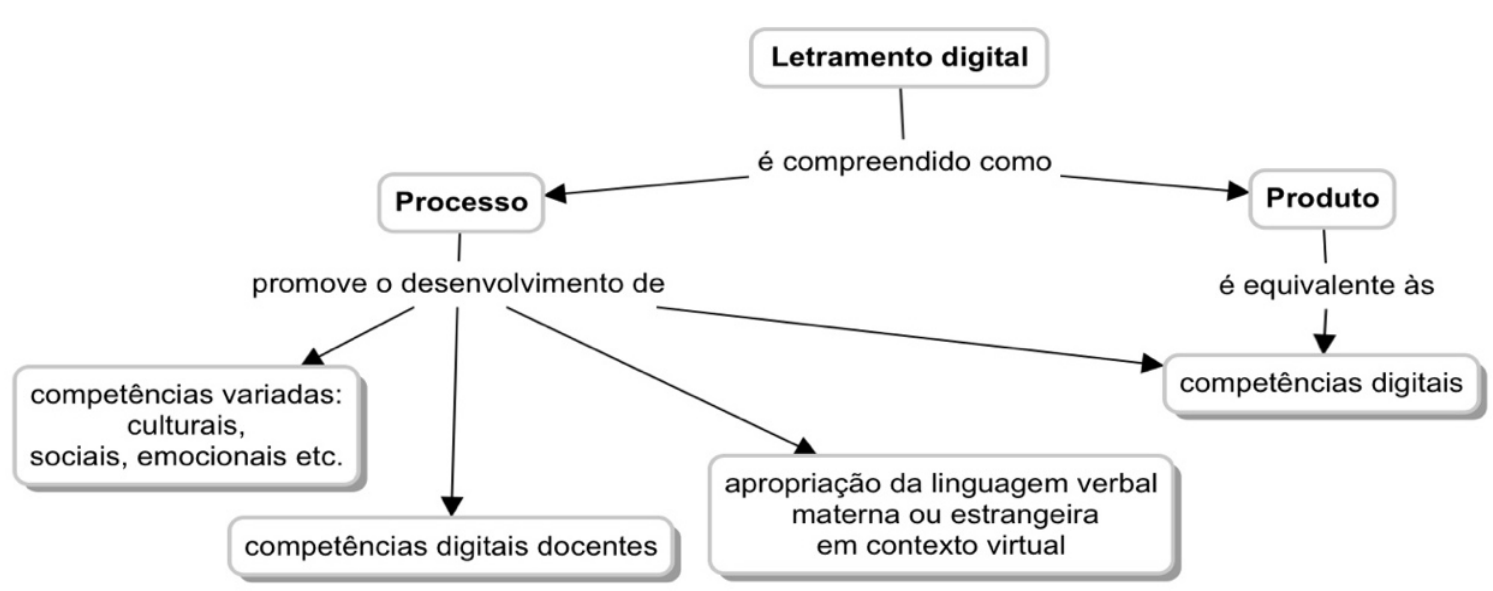

Fonte: Pesquisa da autora (2018)

Foi percebido que o Letramento Digital é tido em alguns estudos, como processo, ou seja, envolve a promoção de estratégias para o desenvolvimento de competências relacionadas à apropriação das TDIC, tais como: competências variadas (manifestas em diversos processos culturais, sociais e emocionais, por

24 Este Mapa conceitual e os subsequentes foram elaborados com base no que orientam Novak e Cañas (2010), utilizando o Cmap Software. Disponível em: <https://cmap.ihmc.us>. 
exemplo); competências digitais docentes (específicas à atuação dos professores no processo de ensino com TDIC); e a apropriação da linguagem verbal materna ou estrangeira (leitura e produção de textos em diversos gêneros em contexto virtual, como crônicas e animações, por exemplo).

Compreendido como produto, o Letramento Digital foi tratado nas produções como equivalente à própria competência digital, ou seja, um conjunto de conhecimentos tecnológicos, informacionais, comunicacionais e multimidiáticos utilizados de forma criativa, crítica, reflexiva, ética e eficaz (ESTEVE MON; GISBERT CERVERA, 2013).

Vale retomar a compreensão de Soares (2014) quando explica, por exemplo, que no contexto escolar, o letramento é um processo, mais que um produto, o que significa, na prática, que as avaliações dos conhecimentos e habilidades, de usos sociais e culturais da leitura e escrita podem ser feitas progressivamente em "vários pontos do contínuo que é o letramento." (SOARES, 2014, p. 84).

E na perspectiva desse continuum, equívocos podem ser evitados na avaliação dos alunos, com a comparação de desempenho em diferentes momentos de letramento. Outro equívoco refere-se à fragmentação, à redução e à limitação do conceito letramento escolar, descontextualizado e validado por testes (COOKGUMPERZ ${ }^{25}, 1986$ apud SOARES, 2014).

Outro aspecto a ser destacado no cenário da revisão de estudos é de cunho quantitativo, e se refere ao número reduzido de artigos, teses e dissertações sobre Letramento Digital no contexto do Ensino Fundamental. Em relação ao número de produções no tema geral - Letramento Digital, especificamente nas bases Capes e IBICT, por exemplo, a proporção é da ordem aproximada de $15 \%$, embora tenha ocorrido um aumento de $72,5 \%$ nos últimos cinco anos (cf. Tabela 2.3).

Quanto aos resultados, a revisão de estudos contribuiu para salientar que os achados das pesquisas empíricas, em seu conjunto, indicam utilidades e funcionalidades das TDIC para o ensino, aprendizagem e desenvolvimento de diversas competências e habilidades, ao mesmo tempo que indicam dificuldades de infraestrutura tecnológica e de recursos educacionais. Cabe destacar a presença de disposição docente para o uso de TDIC, embora existam citações que descrevem a

\footnotetext{
${ }^{25}$ COOK-GUMPERZ, J. Literacy and schooling: an unchanging equation? In: COOK-GUMPERZ, J. (Ed.). The social construction of Literacy. Cambrigde: Cambrigde University Press, 1986. p. 16-44. (Tradução para o português: A construção social da alfabetização. Porto Alegre: Artes Médicas, 1991).
} 
questão de disponibilidade de tempo como uma dificuldade para a interação professor aluno e para a formação docente nas escolas. São reduzidos os artigos que relatam o exercício do Letramento Digital, identificando ações de desenvolvimento e implementação do mesmo no contexto escolar como um todo.

A revisão das produções reforça a compreensão da pesquisadora de que há necessidade de aprofundamento teórico no tema e implementação de ações efetivas de Letramento Digital no desenvolvimento da cultura digital nas escolas, garantida a presença de condições favoráveis da sua multidimensionalidade.

A revisão ainda contribuiu para revelar as tendências da abordagem do tema diante da sua complexidade e do seu conceito polissêmico. Confirma o que assinalou Soares (2002) sobre a imprecisão na definição do termo na literatura brasileira nas áreas de Letras e Educação.

\subsection{CONFIGURAÇÃO DA PESQUISA: A DIMENSÃO EMPÍRICA}

Esta Seção caracteriza a etapa de imersão da pesquisadora no contexto escolar, que ampliou a sua aproximação com o objeto, sob perspectiva inicial de pesquisa exploratória-descritiva (GIL, 2002; SEVERINO, 2007; TRIVIÑOS, 2009). Descreve os procedimentos técnicos, indica os instrumentos de coleta de dados e o tratamento conferido na triangulação, as estratégias metodológicas e as questões éticas. Indica as estratégias de implementação da ação, conforme demandas apresentadas nas Oficinas de Orientação de Estudos, considerando as condições do contexto escolar e do planejamento docente.

O envolvimento da pesquisadora no campo da pesquisa, a Escola Estadual Fernando Nobre, tem como histórico a sua participação no Grupo Alph@ ${ }^{26}$, em ações de projetos ${ }^{27}$ para o desenvolvimento da cultura digital escolar.

${ }^{26}$ Grupo de Pesquisa da FE/USP, sob a coordenação científica da Profa. Dra. Stela C. B. Piconez. O Grupo tem dado oportunidade aos seus membros de realizarem inúmeras reflexões sobre Educação com tecnologias em suas pesquisas acadêmicas na realidade escolar, a exemplo de Bechara (2017), que trabalhou a temática da gestão escolar com o Design Thinking e de Pereira (2018), que pesquisou sobre games nos componentes curriculares da Matemática, dentre outros doutorados em desenvolvimento como os de Ambientes Virtuais em Universidades a distância e sobre desenvolvimento de Letramento Digital em espaços de formação docente.

27 Os projetos do Grupo Alph@ envolvem o corpo gestor, docente e discente em Projetos de Desenvolvimento de Cultura Digital (2014); Criação do Centro Virtual de Formação Permanente (2015); Projeto de Uso de Jogos Digitais e o ensino de Matemática (2016); Projeto de Escrita na Web com Instituto Ayrton Senna (2016); Projeto de Planejamento Integrado sob perspectiva do Design Thinking (2015-2017); Projeto de Recuperação de Aprendizagem com apoio e uso das TDIC (2016-2018). 
A decisão pela pesquisa-ação não foi requisito de escolha da pesquisadora em seu projeto original de pesquisa, mas decorrente de uma solicitação da equipe gestora da Escola, para apoiar o desenvolvimento da cultura digital, no local de trabalho, especificamente com os professores e alunos das Oficinas de Orientação de Estudos, componente curricular do Ensino Fundamental e que tem abertura para a capilaridade nas demais disciplinas, e, portanto, um potencial ponto de apoio, ou mesmo de convergência, dos trabalhos escolares, dando suporte aos demais professores na preparação de pesquisas e orientação das apresentações manuscritas, orais e digitais dos alunos.

A ação nesse tipo de pesquisa, que possibilita o aumento do conhecimento do pesquisador e dos demais participantes quanto à situação em estudo (THIOLLENT, 2011), aproximou a pesquisadora à temática no campo da pesquisa e gerou oportunidade para a compreensão e interpretação do seu objeto de investigação em um movimento de ação-reflexão-ação. Este movimento permitiu atividades de decomposição sistemática dos dados coletados, percebidos em diversas técnicas, registrados e refletidos com os participantes da pesquisa (professores, observadores e alunos).

Essa análise contou com a observação continuada de várias questões relevantes para compartilhamento de situações existentes na identificação do problema da pesquisa. O registro das informações em diários de campo (APÊNDICE B) auxiliou na compreensão do contexto escolar em estudo; favoreceu o estabelecimento de conexões dos dados reconhecidos com a imersão na escola; permitiu identificar a importância dos elementos avaliados pelos professores e alunos; e ajudou na proposição de alternativas de desenvolvimento da cultura digital na Escola, em fluxo natural do currículo escolar.

Novos elementos foram surgindo no desenvolvimento da investigação e contribuíram para a compreensão dos dados. Dentre eles, vale destacar o reconhecimento da parcialidade e da subjetividade (participantes) na distinção das questões principais e secundárias; a diferenciação das informações relevantes das irrelevantes, dada a complexidade do problema; a elaboração das categorias de análise para avaliação do contexto em questão e a percepção das contradições e do hábito de pensar criticamente em processo dinâmico, com conhecimentos pertinentes aos objetivos da investigação. 


\subsubsection{Procedimentos de coleta e tratamento de dados}

A pesquisa adotou em seu desenvolvimento a abordagem qualitativa, pois em certa medida "trabalhou com o universo dos significados, dos motivos, das aspirações, das crenças, dos valores e das atitudes." (MINAYO, 2010, p. 21).

A perspectiva qualitativa foi fundamental diante da complexidade do fenômeno educacional, que envolveu aspectos como formação permanente dos professores, atividades de ensino, aprendizagem dos alunos, horários, estrutura curricular, dentre outros. Explorar um fenômeno social, tal como o Letramento Digital, significou considerar os aspectos envolvidos, conhecer e reconhecer as interferências e interdependência das relações, em que as etapas do processo possuem entre si (FLICK, 2009).

As concepções da pesquisa-ação orientandas pelos estudos de Thiollent (2011) e Tripp (2005) fundamentaram a investigação do objeto em imersão na realidade escolar.

Segundo El Andaloussi ${ }^{28}$ (2004 apud TOLEDO; JACOBI, 2013, p. 157), para alguns pesquisadores, como Thirion (1980), Goyette e Lessard-Hébert (1993), a origem da pesquisa-ação está em trabalhos de Dewey, em 1929, "que ressaltavam a importância de pesquisas sobre a prática escolar a obtenção de melhores resultados a partir do envolvimento dos sujeitos nesse processo". Ainda assim, Toledo e Jacobi (2013) ressaltam que Kurt Lewin, com estudos na área da Psicologia Social na década de 1940, é um dos precursores bastante referenciado, quando se trata de pesquisaação.

Toledo e Jacobi (2013, p. 158) comentam que na consolidação da pesquisaação, sobretudo no campo da educação, há evidências dos pressupostos teóricometodológicos de Paulo Freire $(1987,1996,2003)$ quanto à "importância da reflexão crítica dos sujeitos sobre suas práticas e da problematização da realidade para seu enfrentamento".

\footnotetext{
Abordar a contribuição da Teoria de Paulo Freire na questão das metodologias da pesquisa empírica implica em refletir acerca da relação que se estabelece entre sujeito e o objeto de pesquisa, superando a noção comum do sujeito que pesquisa atuando sobre os sujeitos que são pesquisados, de modo unilateral e vertical. (MÉKSENAS, 2007, p. 2).
}

28 EL ANDALOUSSI, K. Pesquisas-ações: ciências, desenvolvimento, democracia. São Carlos: Edufscar, 2004. 
Dessa maneira, a opção metodológica da pesquisa-ação se contrapõe à percepção de sujeito de pesquisa como um mero informante. Ao mesmo tempo em que o participante da pesquisa traz suas respostas às questões em estudo, emite sua opinião, valores, crenças e expressa seus conhecimentos sobre a questão pesquisada (MINAYO, 2010; THIOLLENT, 2011).

A articulação da teoria e prática sinalizou a perspectiva de reflexão e ação no contexto escolar. A situação concreta que orientou a pesquisa-ação foi o empenho no desenvolvimento de atividades de Letramento Digital nas Oficinas de Orientação de Estudos, de forma cooperativa.

Esta pesquisa teve permanente revisão do seu percurso metodológico, pois todo o processo de desenvolvimento foi realizado em conjunto com os participantes envolvidos e suas demandas. A formulação do problema, os objetivos, as possíveis hipóteses, a coleta e tratamento de dados foram discutidos com o corpo gestor da escola, professores, observadores e pesquisadores do Grupo Alph@. A tarefa da pesquisadora referiu-se também em agregar as reflexões efetuadas com todos e com sua orientadora, e preservar o caráter científico da pesquisa, na análise sistemática e crítica da realidade estudada.

O arranjo e a sequência das ações vivenciadas passaram pela criação de um Design pedagógico que incorporasse as TDIC nas Oficinas em foco; pelas contribuições em relação à formação dos professores e pela ampliação de desenvolvimento da cultura digital na Escola. Isto foi desenvolvido tendo como pressuposto o que foi identificado por Thiollent, que "desenvolver a consciência da coletividade nos planos político ou cultural a respeito dos problemas importantes que enfrentam, mesmo quando não se vêem soluções a curto prazo." (THIOLLENT, 2011, p. 18).

A população pesquisada envolveu os professores das Oficinas de Orientação de Estudos e os 218 alunos do $6^{\circ}$ ao $9^{\circ}$ ano do Ensino Fundamental II, distribuídos em sete turmas ( $6 \mathrm{~A}, 7 \mathrm{~A}, 7 \mathrm{~B}, 8 \mathrm{~A}, 8 \mathrm{~B}, 9 \mathrm{~A}$ e $9 \mathrm{~B}$ ), com a média de 30 alunos por turma.

Como observadores da pesquisa-ação participaram: o professor responsável pelo letramento em Sala de Leitura, a Coordenadora pedagógica e a Orientadora de Informática educacional. A Coordenadora pedagógica é formada em Licenciatura em História, pelo Centro Universitário da Fundação Instituto de Ensino para Osasco, em Osasco (SP); a colaboradora na área de Informática educacional, a Profa. Josete 
Zimmer, é Pedagoga pela Faculdade de Filosofia, Ciências e Letras São Carlos Pasquale, em São Paulo (SP) e Mestre em "Comunicação Educacional Multimédia", pela Universidade Aberta de Portugal; e o Prof. da Sala de Leitura tem formação em Letras e pós-graduação lato sensu em Literatura Brasileira, pela Faculdade de Hoyller de Letras, em Vargem Grande Paulista (SP). O universo da população descrita abrangeu também o Diretor da Escola.

Para o cumprimento dos objetivos propostos na investigação e com a finalidade de obter maior compreensão do objeto investigado foi adotada a triangulação na coleta e análise de dados (GUIMARÃES et al., 2004; TRIVIÑOS, 2009).

Inicialmente, na fase diagnóstica houve a coleta de dados no primeiro semestre de 2016 para a identificação do contexto político-administrativo-pedagógico e tecnológico da escola e conhecimento dos participantes da pesquisa, de suas práticas pessoais e escolares com as TDIC por meio de entrevistas semiestruturadas, questionários, observação, diário de campo e pesquisa documental.

Decorrente da análise do diagnóstico realizado, na fase de planejamento da pesquisa-ação para criação do design pedagógico e implementação da Ação, a pesquisadora respeitou o limite para a sua atuação em termos do tempo disponível dos professores e na extensão de sua abordagem teórico-prática, com base na rede de significados identificadas. Essa fase ocorreu consonante à dinâmica da pesquisaação, isto é, os participantes nesse tipo de pesquisa contribuem para o estudo (THIOLLENT, 2011; TRIPP, 2005). Com base nestes autores, as ações de criação e implementação de um design pedagógico com suporte das TDIC apoiou-se:

[...] na preocupação de garantir a participação ativa do grupo no processo de tomada de decisões sobre assuntos que lhes dizem respeito, com vistas à transformação social, não se tratando, portanto, de uma simples consulta, mas sim do envolvimento dos participantes da pesquisa em um processo de reflexão, análise da realidade, produção de conhecimentos e enfrentamento dos problemas. (TOLEDO; JACOBI, 2013, p. 156).

A construção da Ação com a realização de atividades com TDIC nas Oficinas foi caracterizada como pré-requisito de participação, diálogo e produção de saberes entre os interessados (pesquisadores, participantes e tomadores de decisão), e mostrou-se potencialmente eficaz dada a complexidade das situações enfrentadas nas diversas dimensões do contexto escolar.

Nessa fase da pesquisa foram, continuamente, conhecidas as condições, ocorrências, necessidades e desafios encontrados por professores e alunos nas ações educativas apoiadas por TDIC, com subsídios das técnicas e instrumentos de 
pesquisa documental, observação participante, diário de campo e da contribuição dos participantes em grupo focal.

Completando cada ciclo da pesquisa-ação, a fase de avaliação da Ação envolveu as observações registradas nos diários de campo, reuniões nos grupos focais e pesquisa documental. E após a concretização do último ciclo foram aplicados questionários.

De acordo com Gatti (2005), na pesquisa em Ciências Humanas se almeja a compreensão, o impacto de caráter prático nas transformações sociais que combinem capacidade dedutiva e indutiva obtidos pelo contexto. Assim, as reuniões de grupo focal tiveram por objetivo buscar o entendimento das raízes do problema, como se manifestam em seu processo, muitas vezes subentendidos nas atitudes, posturas e nos valores expressos pelos participantes. Também cumpriram a finalidade de analisar a ação em curso, quanto ao aperfeiçoamento para que as dificuldades fossem organizadas e compreendidas naquele contexto.

As técnicas e instrumentos foram definidas a fim de contemplar os ângulos da triangulação, a saber: 1. Ângulo dos processos e produtos originados pela estrutura social na qual estão inseridos os participantes; 2. Ângulo dos elementos produzidos pelo contexto dos participantes; 3 . Ângulo dos processos e produtos centrados nos participantes (TRIVIÑOS, 2009).

No ângulo referente aos processos e produtos originados pela estrutura social em que estão inseridos os participantes foram adotados na fase diagnóstica o estudo bibliográfico e a pesquisa documental, com a análise de objetos que se tornaram suporte material de informação (SEVERINO, 2007), como documentos da Secretaria de Educação do Estado de São Paulo (SE/SP) e da Escola, bem como a legislação estadual pertinente ao tema da inserção/uso das TDIC nas escolas.

Quanto ao ângulo referente aos elementos produzidos pelo contexto dos participantes, os dados foram coletados por pesquisa documental em documentos da instituição e dos participantes, com a observação participante e diários de campo.

Para pesquisa documental foram consultados (APÊNDICE C): planos didáticos, trabalhos escolares, e em meio digital, os registros nas diversas mídias utilizadas na Escola Fernando Nobre e em site da SE/SP sobre notícias de atividades realizadas com TDIC na Escola. No blog das Oficinas contou-se com dados de 55 alunos comentaristas, o equivalente a $25 \%$ dos alunos da Escola. 
$\mathrm{Na}$ observação participante, a coleta de dados ocorreu diretamente pela pesquisadora em situação natural na Escola. Essa técnica pode produzir uma compreensão dos fatos do contexto investigado, mediante a interação nas situações reais do cotidiano. Exige registro adequado e cuidados, a fim de evitar impressões de cunho emocional e deformações subjetivas sem comprovações com dados (CHIZZOTTI, 2010).

As observações ocorreram em diversos momentos: aulas, eventos escolares e científicos, reuniões de planejamento, denominadas de Horário de Trabalho Pedagógico Coletivo (HTPC). Os dados observados foram registrados ${ }^{29} \mathrm{em}$ fotografias, vídeos e em diários de campo. O APÊNDICE D elenca os itens que guiaram a observação; o APÊNDICE B demonstra alguns diários de campo. Estes últimos têm caráter flexível, descritivo e possibilitam sínteses provisórias (DAL PRÁ; LIMA; MIOTO, 2007). Os diários de campo contêm as observações, impressões, reflexões do pesquisador de modo que possa contribuir com a tessitura de seu relatório de pesquisa.

No ângulo referente aos processos e produtos centrados nos participantes, os dados foram coletados em questionários, entrevistas semiestruturadas e grupo focal.

A técnica do questionário fornece informações obtidas em números e outros elementos para a análise qualitativa (TRIVIÑOS, 2009; GIL, 2002).

$\mathrm{Na}$ fase de diagnóstico, o Questionário $\mathrm{A}$ foi respondido pelos professores e o Questionário B, pelos alunos (APÊNDICES E e F). Foram impressos em papel sulfite e aplicados presencialmente na Escola em um período de cinco dias. E ao final da investigação, os Questionários C, D e E, elaborados no Formulário Google (Google Forms), foram enviados por e-mail e postados em blog da escola para identificar desafios, contribuições e impressões do uso das TDIC, sendo respondidos por professores, alunos participantes e observadores, respectivamente (APÊNDICES G, $\mathrm{H}$ e I). Todos os questionários passaram pelo pré-teste com três professores e dez alunos, a fim de avaliar sua pertinência e fazer os ajustes necessários.

Em resposta ao Questionário B (sondagem diagnóstica inicial), dos 218 alunos participantes das Oficinas, participaram 46 deles, o que representa $21 \%$ do total. E para o Questionário D (avaliação da ação), 69 alunos responderam, o que representa $32 \%$ dos alunos da Escola.

\footnotetext{
${ }^{29}$ As imagens das atividades com os participantes não estão apresentadas na tese por questões de ética na pesquisa.
} 
A entrevista semiestruturada permitiu conhecer os desdobramentos que nas análises guardaram articulação interna, com abertura para a categorização posterior (QUIVY; CAMPENHOUDT, 2008; SEVERINO, 2007). Essa técnica foi adotada com a Coordenadora pedagógica, Direção da Escola e com os professores das Oficinas de Orientação de Estudos (APÊNDICE J).

A técnica de grupo focal, a partir das experiências individuais e grupais, favoreceu a compreensão das relações existentes no contexto escolar relacionada com a temática da pesquisa, em clima de interação entre os participantes. Auxiliou na reflexão sobre a pesquisa, sobre o pensar colaborativo e o fazer parte do grupo.

Todas as sessões contaram com a participação de observadores e alguns membros do Grupo Alph@. A moderação das reuniões foi realizada pela pesquisadora, com apoio da sua orientadora nos diversos momentos: abertura, explicação da técnica, aquecimento do grupo e aprofundamento de tópicos específicos sobre o uso educativo de TDIC.

Foram realizadas três sessões de grupo focal, cada uma com duração aproximada de uma hora e meia. No decorrer da pesquisa ocorreram duas sessões com representação de todos os participantes e, ao final da pesquisa, foi realizada uma sessão somente com professores e observadores (APÊNDICE K).

A triangulação nesta investigação foi adotada não como modelo de validação mútua, mas como complementaridade (GUIMARÃES et al., 2004; TRIVIÑOS, 2009). Fortaleceu o entendimento do contexto escolar mais próximo de sua realidade.

O Mapa 2.2 ilustra a distribuição e interação das técnicas e instrumentos, que foram utilizados para a triangulação de dados nas diversas fases da pesquisa-ação.

Mapa 2.2 - Procedimentos, técnicas e instrumentos - Pesquisa-ação

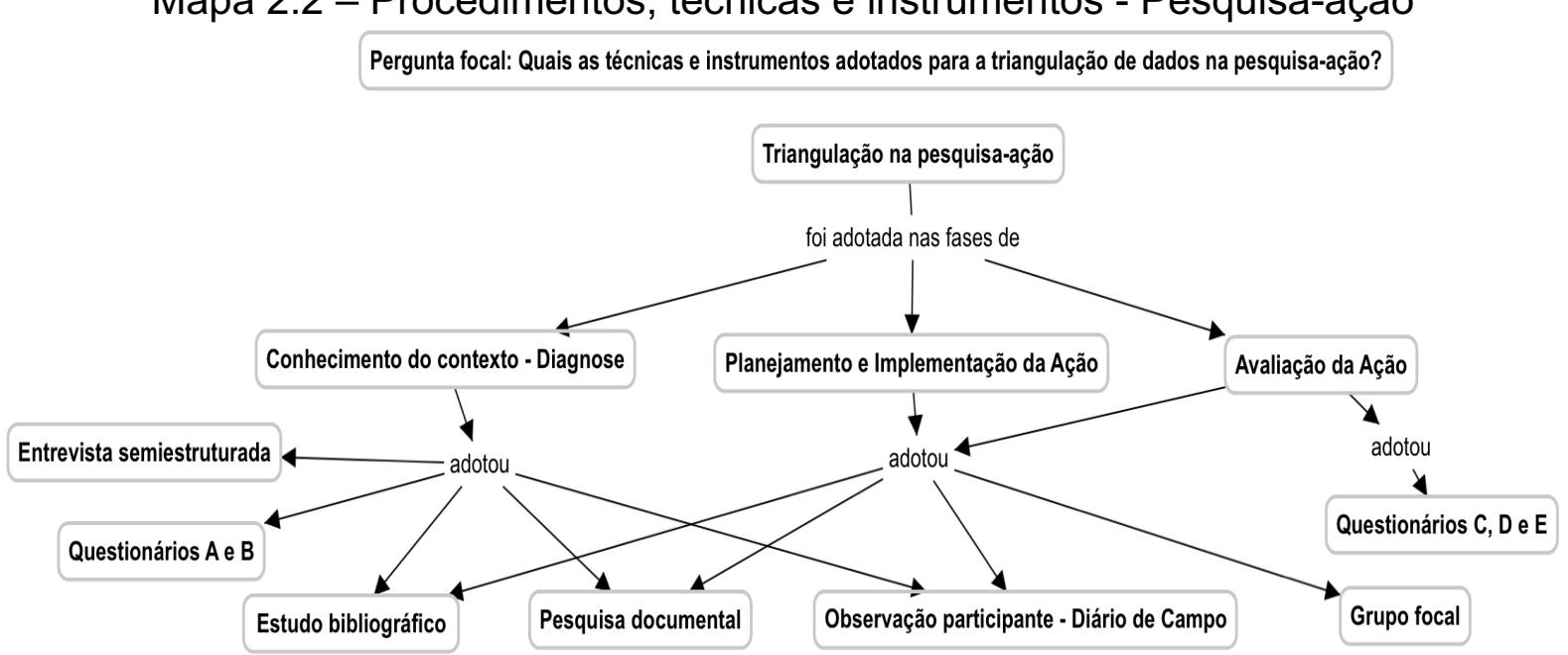

Fonte: Pesquisa da autora (2018) 
Para a análise dos dados empíricos, sua constituição se deu a partir da audição, transcrição, leitura e revisão cuidadosa dos dados coletados nas diversas técnicas.

Os fragmentos dos textos constantes nesta tese guardaram fidedignidade à escrita original do informante. Foram utilizados os recursos [pausa], [risos] e [!] com objetivo de contemplar a fidelidade das ações, nas pausas e entonações orais, expressas pelos participantes.

Os dados qualitativos do material coletado passaram por procedimentos de análise sem uso de programas específicos. E para os cálculos estatísticos dos dados oriundos dos questionários e da pesquisa documental nas mídias e para a construção de gráficos e tabelas foi utilizado o Excell.

Para os cálculos percentuais de dados foram consideradas as normas da Associação Brasileira de Normas Técnicas (ABNT) NBR 5891/2014, que dispõe sobre as regras de arredondamento de numeração decimal. Com os dados obtidos de forma quantitativa, outras leituras e reflexões favoreceram a tradução das informações, para a análise qualitativa que foi efetivada (GIL, 2002; TRIVIÑOS, 2009).

A técnica de análise de conteúdo, que atende ao princípio de rigor e profundidade necessário à pesquisa qualitativa possibilitou o tratamento das informações de forma metódica, com certo grau de complexidade (QUIVY; CAMPENHOUDT, 2008).

Essa técnica reduz a complexidade da coleção de dados, por conter de forma objetivada todo o estrato reunido na investigação, ou melhor, de todo o corpus da pesquisa, não sendo necessário anexar todos registros originais nos elementos póstextuais (BAUER, 2011).

Os procedimentos de análise e interpretação dos dados coletados respeitaram as aproximações temáticas no texto obtido com as diversas técnicas utilizadas.

Os dados foram agrupados em contextos temáticos; na sequência foram efetuadas diversas leituras para exploração do material na tarefa de categorização, análise dos resultados e interpretação, com o propósito de relacionar os núcleos de sentido com os objetivos da investigação (BARDIN, 2011).

A análise detalhada favoreceu a categorização em quatro dimensões, que foram configuradas para favorecer a interpretação dos dados: infraestrutura; administrativapedagógica; didática-pedagógica e pessoal (APÊNDICE L, Quadro 2.6). Na Seção 3.3 , tais dimensões são consideradas na diagnose, ou seja, como resultado dos dados 
coletados na primeira fase da pesquisa-ação. E no Capítulo 5 estão absorvidas nos resultados da Ação implementada.

Em atenção às questões éticas, por se tratar de pesquisa envolvendo seres humanos ${ }^{30}$, foram respeitados os procedimentos exigidos pelo Programa de Pósgraduação da FE/USP, com submissão do projeto de pesquisa ao Comitê de Ética em Pesquisa (CEP) do Instituto de Psicologia da USP e à Comissão Nacional de Ética em Pesquisa (Conep), sendo aprovado com o Parecer $n^{\circ} 1.533 .251$, de 6 de maio de 2016.

Foi solicitada a autorização da Direção da Escola Fernando Nobre e para os participantes e observadores o convite foi individualizado, apresentando-se o objetivo, os procedimentos e os critérios éticos, com leitura e assinatura do Termo de Consentimento Livre e Esclarecido - TCLE (APÊNDICE M). No corpo da tese a identidade dos participantes ${ }^{31}$ foi preservada, sendo adotado nomes fictícios.

Para esclarecimentos com relação às dúvidas éticas do Projeto, os participantes foram informados de que poderiam entrar em contato com a pesquisadora presencialmente na Escola Fernando Nobre, por e-mail ou por telefone, ou diretamente no CEP do Instituto de Psicologia da USP. Após a finalização da pesquisa, os professores, coordenação e gestores da escola continuam em contato, e os trabalhos derivados das Ações implementadas, via redes sociais.

A divulgação externa dos resultados da investigação será dada mediante o arquivo digital nos Bases BDTD.USP, CT.Capes e do BDTD.IBICT; na Biblioteca da FE/USP; na Biblioteca Central da UEMA, instituição onde a pesquisadora exerce a docência em cursos de formação de professores; e em publicações de artigos em livros, periódicos e eventos científicos.

Todos os instrumentos, registros em fotografias, vídeos, gravações e as transcrições dos dados ficarão guardados na residência da pesquisadora por um período de cinco anos, a contar a defesa da tese e depois serão descartados.

30 Regulamentação pela Resolução do CNS n 466/2012 (BRASIL, 2012).

31 Por solicitação da pesquisadora, a Profa. Josete Zimmer, que tambem é membro do Grupo Alph@, autorizou a menção de seu nome na tese. 


\subsubsection{Estratégias da Ação implementada e as questões éticas}

Os ciclos da pesquisa-ação foram concretizados no fluxo das atividades das Oficinas de Orientação de Estudos, inseridos em seu planejamento e em suas atividades durante o terceiro e quarto bimestres de 2016, com estratégias compatíveis à realidade escolar.

Por isso, as estratégias e uso das TDIC na Ação implementada decorreram das demandas existentes nas Oficinas, considerando as condições do contexto escolar e do planejamento docente.

A atuação pedagógica da pesquisadora (designer) foi dada mediante a orientação das atividades de planejamento dos professores; planejamento, elaboração e apresentação de recursos didáticos ${ }^{32}$ específicos para professores e alunos (slides, tutoriais e vídeos); criação e organização de um blog para as Oficinas Orientação de Estudos; e suporte técnico e pedagógico durante as aulas no Laboratório para a realização de trabalhos das Oficinas, apoiados pelas TDIC (APÊNDICE N).

Houve acompanhamento das aulas nas Oficinas, reuniões, exposições dialogadas, exercícios práticos e orientação aos professores em encontros que variavam de 40 a 120 minutos.

Para interação exclusivamente com os professores, foram realizados encontros presenciais e a distância, mediante comunicação síncrona e assíncrona.

A orientação aos professores em momentos de atuação junto aos alunos se deu durante as aulas das Oficinas no Laboratório de Informática e em salas de aula convencionais e em atividades extraclasse, como seminários e oficinas temáticas. Esses momentos contaram com a presença de observadores da pesquisa e de pesquisadores do Grupo Alph@.

Para manter o respeito às condições existentes na Escola e "não correr o risco de parecer invasão", como alerta Machado (2015, p. 163), na abordagem junto aos professores, a negociação foi uma constante, com apoio à integração de tecnologias digitais e não-digitais como o caça palavras, dicionários impressos, desenhos em

\footnotetext{
32 Todos os recursos didáticos produzidos pela pesquisadora foram compartilhados com a escola durante a pesquisa. Disponíveis em: <http://cursosextensao.usp.br/course/view.php?id=264>;

$<$ http://pesquisanobre.blogspot.com.br>.
} 
sulfite, trabalhos manuais e outros. Foram considerados tanto os materiais existentes na escola, como respeitados os já conhecidos pelos professores e alunos.

O Mapa 2.3 oferece um registro panorâmico das estratégias didáticopedagógicas empregadas na Ação implementada.

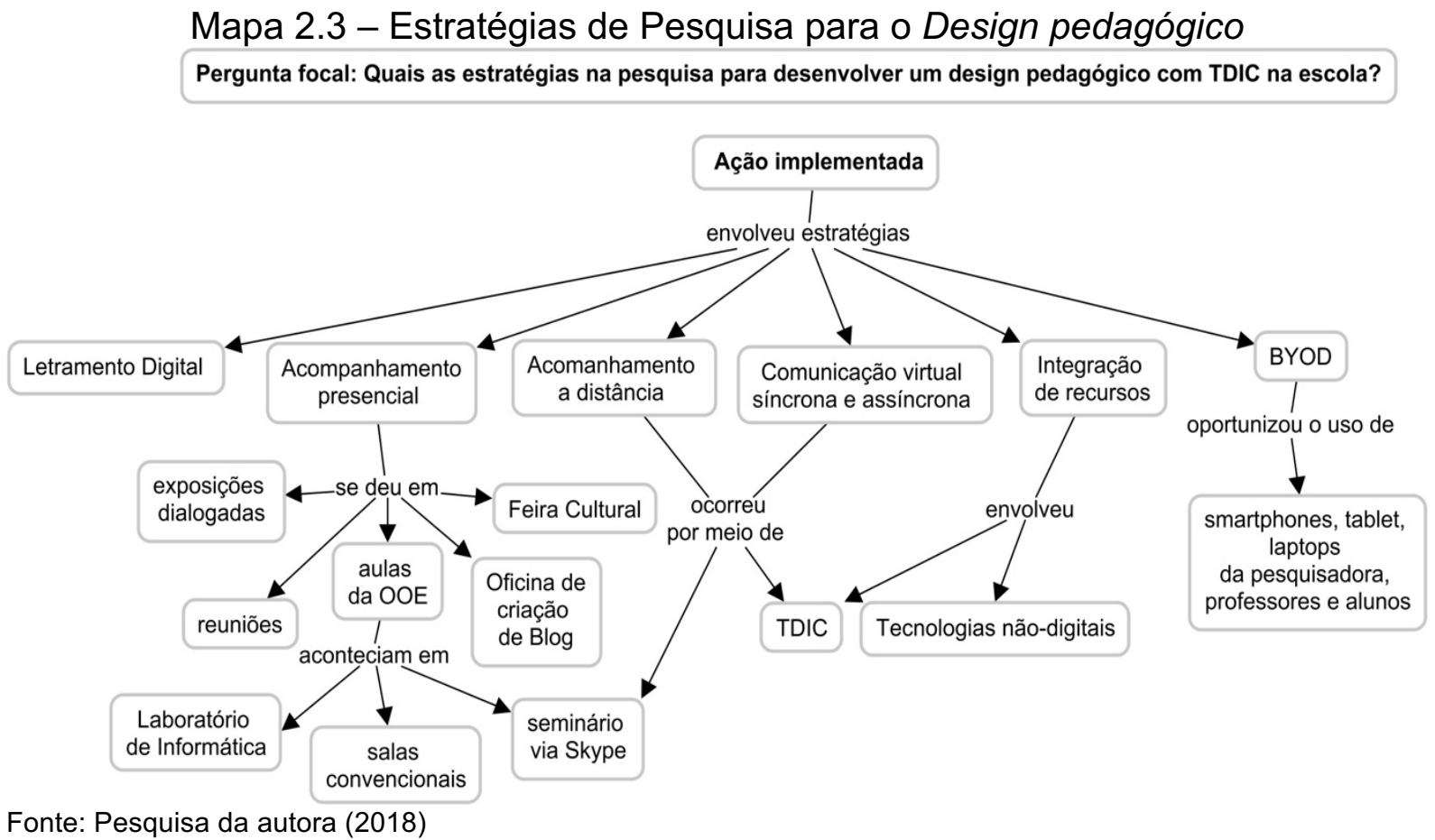

As TDIC disponíveis à época desta investigação na Escola Fernando Nobre podiam ser acessadas no Laboratório de Informática, com alguma dificuldade, como descrito na Seção 3.3. Entretanto, nas discussões com professores, alunos e observadores foi encontrada uma solução na perspectiva do BYOD, que consistiu em aproveitar laptops, smartphones e tablets de participantes para que ocorressem também os acessos a aplicativos, a fim de desenvolver as atividades escolares.

Cada tecnologia foi utilizada durante a Ação implementada, com intencionalidade educativa, conforme relação a seguir.

1 Plataforma Moodle para postagem de material didático, formação e orientação aos professores das Oficinas em fóruns de discussão e espaços dedicados para comunicação com a Direção;

2 Aplicativo Animoto para produção em vídeos das narrativas dos projetos dos alunos no percurso das Oficinas;

3 Apresentações Google (Google Slides) para (co) organização, produção de apresentações e comunicação dos trabalhos dos alunos nas Oficinas; 
4 Arquivo Portable Document Format (PDF) para compartilhamento de material produzido pela pesquisadora, professores e alunos;

5 Documentos Google (Google Docs) para (co) organização, produção e comunicação de material didático da pesquisa, das Oficinas e dos trabalhos dos alunos;

6 e-mail para informações, orientações entre os participantes e para a comunicação e avaliação dos alunos;

7 Facebook, em grupo fechado com os professores, a pesquisadora e a orientadora científica, para provocações cognitivas e compartilhamento de tutoriais e vídeos; e, os alunos participavam do Facebook da escola;

8 Formulário Google (Google Forms) para elaboração de questionários das tarefas e pesquisas escolares e das Oficinas;

9 Google Drive para planejamento, organização, armazenamento, compartilhamento de documentos da pesquisadora, dos professores e dos alunos e para a avaliação dos trabalhos escolares;

10 Google Hangouts para reuniões da pesquisadora com professores das Oficinas, com a orientadora da pesquisa e participantes do Grupo Alph@;

11 O Blog, no Aplicativo Google Blogger, para organização e informação dos conteúdos das Oficinas e servir de espaço de convergência das atividades nesse componente curricular e favorecer a construção de conhecimentos discente e a avaliação da aprendizagem;

12 Programa PowerPoint para produção, edição e comunicação de apresentações de conteúdos da pesquisa, das Oficinas e de trabalhos dos alunos;

13 Programa Word para produção, edição de textos da pesquisa, das Oficinas e de trabalhos dos alunos;

14 Sites de busca de conteúdo para as tarefas escolares, demandas próprias das Oficinas, das demais disciplinas, com finalidade de busca e seleção de fontes e informações na $W e b$;

15 Skype para comunicação, acompanhamento em apresentações orais dos alunos nas Oficinas, com suporte do Datashow; e

16 WhatsApp para orientação aos professores das Oficinas em acompanhamento informal, troca de mensagens instantâneas, comunicação e informações orientadoras entre pesquisadora e os professores. Os alunos 
formaram grupos para discussão entre eles acerca das tarefas e projetos da escola.

O uso das TDIC favoreceu o entendimento de que elas têm um caráter subsidiário (MACHADO, 2015), e por isso, estiveram presentes em diversos momentos da prática educativa, sendo acessadas em vários dispositivos e com objetivos específicos.

As TDIC foram inseridas como suporte para o desenvolvimento de ações docentes (mapear, narrar, tecer e mediar) para ampliar o Letramento Digital. O Mapa 2.4 ilustra a relação de uso das TDIC e suas finalidades.

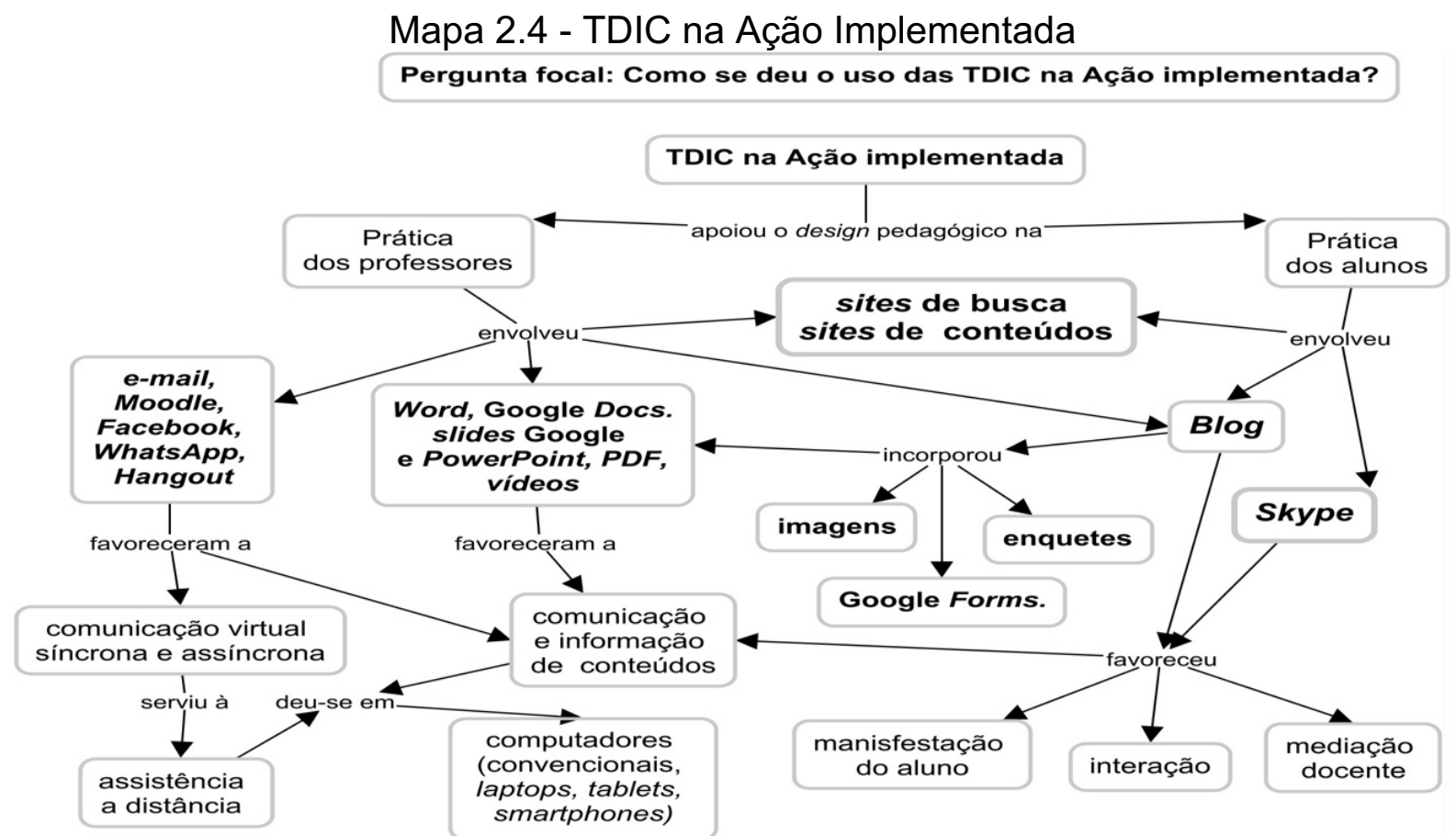

Fonte: Pesquisa da autora (2018)

O acompanhamento dessas vivências incorporou a criação de um design pedagógico (Capítulo 4) e suas contribuições estão relatadas no Capítulo 5.

A seguir, o Capítulo 3 caracteriza em detalhes, o campo e participantes da pesquisa em suas aproximações com as TDIC. 


\section{A ESCOLA ESTADUAL FERNANDO NOBRE: O CONTEXTO DA PESQUISA}

Este Capítulo cumpre um dos objetivos específicos necessários para elaborar um quadro comparativo do contexto político-administrativo-pedagógico e tecnológico na escola-campo, para compreender as influências e contribuições durante o período de intervenção; e a constatação da presença de Letramento e fluência digital entre professores e alunos participantes da pesquisa.

A Seção 3.1 descreve a Escola Estadual Fernando Nobre, especifica seus espaços, organização curricular, recursos dedicados ao uso das TDIC e o componente curricular foco da pesquisa no contexto escolar, a Oficina Orientação de Estudos.

\subsection{CONTEXTO POLÍTICO-ADMINISTRATIVO-PEDAGÓGICO E TECNOLÓGICO}

Os dados referidos nesta Seção foram coletados na entrevista semiestruturada, na observação participante e diário de campo e na pesquisa documental, apoiandose também em informações legais pertinentes. Tiveram por finalidade auxiliar na caracterização contextual da escola.

A Escola Estadual ${ }^{33}$ Fernando Nobre, citada nesta tese como Escola Fernando Nobre, foi criada ${ }^{34}$ em 1969, com o nome de Grupo Escolar do Km 21.

Ao longo da sua existência, ofereceu Ensino Fundamental anos iniciais e finais, Educação de Jovens e Adultos (EJA), Telesala e Ensino Médio, e a partir de 2006 passou a atender somente o Ensino Fundamental, anos finais, aderindo ao Projeto Escola de Tempo Integral $(E T I)^{35}$, um dos modelos de escola que amplia a jornada discente no Estado de São Paulo.

\footnotetext{
${ }^{33}$ A Escola Fernando Nobre é uma das escolas de Ensino Fundamental com dependência administrativa estadual dentre $42 \%$ das escolas localizadas em Cotia (SP). No Brasil esse índice é da ordem de 31,7\% (INEP, 2017).

${ }^{34}$ Resolução SE n 24/1969, Diário Oficial do Estado de São Paulo, 29/01/1969.

35 O Projeto ETI foi instituído pela Resolução SE n 89/2005 (SÃO PAULO, 2005). Nesse modelo, os professores não têm exclusividade na escola, podem ser contratados temporariamente por processo seletivo previsto em Lei (SÃO PAULO, 2009, 2015a). As ETI se diferenciam do Modelo Programa de Ensino Integral (PEI) em diversos aspectos, dentre os quais, destaca-se: no PEI os professores atuam em regime de dedicação plena e integral, com 40 horas semanais, com gratificação de $75 \%$ em seu salário; apenas poderá ser permitida a contratação de professor por tempo determinado em caso de atendimento a alunos especiais (SÃO PAULO, 2012a, 2014d, 2015b).
} 
Está situada na Rua Riacho, $n^{\circ}$ 50, no Jardim Guerreiro, Km 21 da Rodovia Raposo Tavares, na zona urbana do município de Cotia (SP), ligada à Diretoria de Ensino Região de Carapicuíba. Tem atendido alunos moradores das comunidades do entorno.

A maioria dos alunos faz parte de família de baixa renda, com pais, mães ou responsáveis, trabalhadores domésticos, comerciantes e prestadores de serviços, conforme descrito no Plano Escolar (EEFN, 2013).

Quanto ao espaço escolar, a Escola está sediada em um prédio construído em 1976, com área total de 5.153,10 $\mathrm{m}^{2}$, sendo $1.570 \mathrm{~m}^{2}$ de área construída.

Para as atividades administrativas dispõe de uma sala para Direção, uma sala para a Secretaria e uma sala para guarda de material escolar; seis salas de aula, uma Sala de Leitura e um Laboratório de Informática ${ }^{36}$ com 15 computadores $^{37}$ instalados, adquiridos em 2014, pelo Programa Acessa Escola ${ }^{38}$, sendo que três deles não estavam funcionando. O acesso à Internet é disponibilizado pelo Governo do Estado de São Paulo 39 .

Para apoio ao corpo docente, disponibiliza uma Sala para a Coordenação Pedagógica e uma Sala de professores; um computador ligado à Internet; uma mesa para reuniões e armários para guarda de pertences e de material didático.

Para o cuidado com a alimentação dispõe de uma cozinha, uma despensa para alimentos e um refeitório. Possui um banheiro masculino e um feminino para uso discente, localizados no pátio interno; e banheiros para funcionários, gestores e professores, localizados na área administrativa. Na área externa encontra-se um pátio coberto, um pátio em área cimentada a céu aberto e uma quadra poliesportiva coberta.

A equipe escolar estava assim constituída ${ }^{40}$ em 2016: um diretor efetivo; uma vice-diretora designada; uma gerente de organização escolar designada; uma coordenadora pedagógica designada; uma professora efetiva adaptada, que colaborava na área de Informática educacional e um professor contratado, que atuava

\footnotetext{
${ }^{36}$ Das 62.5 mil escolas de Ensino Fundamental, anos finais no Brasil apenas 67,8\% dispunham de Laboratório de Informática; $75,6 \%$ dispunham de computadores para os alunos, $85 \%$ para uso administrativo e $81 \%$ das escolas estavam com acesso à internet (INEP, 2017).

37 Especificação dos computadores: fabricante Positivo, processador Intel, Core $^{\mathrm{TM}} \mathrm{i5}$, sistema operacional Windows 7 professional, 64 bits, com 8192MB RAM.

38 Informações disponíveis em: <http://www.educacao.sp.gov.br/acessa-escola/>.

${ }^{39}$ Projeto Intragov que se constitui no alicerce da Política de Governo Eletrônico. Informações em: <http://www.intragov.sp.gov.br/>.

40 Em 2017, por medida da SE/SP, as escolas com menos de 300 alunos deixaram de possuir vice-diretor coordenador e pedagógico, resultando no retorno da Vice-Diretora e da Coordenadora pedagógica à sala de aula. O Quadro docente é rotativo, dada a condição de professores contratados no Estado.
} 
na Sala de Leitura. O corpo docente em sala de aula estava composto por 7 professores efetivos e 12 contratados, que permanecem na Escola temporariamente, não tendo vínculo empregatício com o Estado. Para os serviços de alimentação e limpeza, contava com pessoal de duas empresas terceirizadas: uma cozinheira, uma ajudante de cozinha e dois auxiliares de limpeza.

A organização curricular da Escola Fernando Nobre, no ano de 2016 foi regida pela Resolução SE n 6, 19 de janeiro de 2016. Sua Matriz Curricular, que se encontra no ANEXO A, integra 28 aulas semanais nas disciplinas da Base Nacional Comum para os anos finais do Ensino Fundamental e 12 aulas semanais nos componentes curriculares da Parte Diversificada: Oficinas de Língua Estrangeira - Inglês, Leitura e Produção de Texto, Experiências Matemáticas, Linguagens Artísticas, Cultura do Movimento e Orientação de Estudos (SÃO PAULO, 2016a, 2016b). O horário de funcionamento das oficinas, definido pela Direção da Escola, ocorria das 13h:20min às $15 \mathrm{~h}$.

Para o planejamento docente, os HTPC aconteciam das $15 \mathrm{~h} 20 \mathrm{~min}$ às $17 \mathrm{~h}$, às quartas-feiras. Na oportunidade, ocorriam discussões sobre o comportamento e desempenho dos alunos; informações e orientações para atividades escolares; planejamento didático individual ou por áreas; e eventualmente, atividades de formação permanente. A Coordenadora pedagógica disponibilizou aos professores um modelo de plano, sugerindo a adoção das habilidades contidas nos documentos orientadores da SE/SP (ANEXO B).

Para as disciplinas, a SE/SP fornecia recursos pedagógicos de apoio ao Currículo, tais como: o Caderno do Professor, com orientação didático-pedagógica para situações de aprendizagem e o Caderno do Aluno, por disciplina (SÃO PAULO, 2014a, 2014b); recursos complementares para implementação do currículo como os Livros didáticos do Programa Nacional do Livro Didático (PNLD) ${ }^{41}$, livros paradidáticos e de literatura, e material digital CD, DVD e via "Plataforma Currículo+" (SÃO PAULO, 2012b). Para as oficinas curriculares nas ETI não havia material específico.

No processo avaliativo nos componentes curriculares, inclusive nas oficinas, os professores empregavam técnicas e instrumentos diversificados a depender de suas condições de tempo, número de alunos, assuntos e prazos, variando entre exercícios, trabalhos de pesquisas individuais e em grupo, realizados tanto em tarefas de casa

${ }^{41}$ O PNLD subsidia o trabalho pedagógico docente por meio de distribuição de coleções de livros aos alunos da Educação Básica. Informações em: <http://www.fnde.gov.br/programas/livro-didatico>. 
ou na classe, provas etc. As notas eram expressas numericamente, conforme a Resolução SE n 6/2016 (SÃO PAULO, 2016a), entretanto, a composição variava entre os professores, o lançamento dos resultados era bimestral, em cadernetas e no Sistema ${ }^{42}$ online da Secretaria Escolar Digital.

As TDIC disponíveis às escolas no Estado de São Paulo, no período compreendido por esta investigação, eram fomentadas pela SE/SP, que instituiu em 2014 o Programa Novas Tecnologias - Novas Possibilidades (SÃO PAULO, 2014c), visando o emprego sistemático de TDIC em salas de aula nas escolas da rede estadual de ensino, que é integrado ao Programa Educação - Compromisso de São Paulo (SÃO PAULO, 2011).

A infraestrutura em TDIC e a formação permanente de professores nas escolas paulistas eram norteadas pelo Currículo (SÃO PAULO, 2008), o qual em fase inicial de implantação previa dois projetos: A "Plataforma Currículo+" e o "Professor 2.0".

Em linhas gerais, o primeiro, por meio de conteúdos digitais articulados em sua Plataforma online (SÃO PAULO, 2008), e o segundo, mediante a possibilidade de troca de experiências, atividades, ferramentas e produção docente com TDIC, para mobilizar o aprendizado em rede (SÃO PAULO, 2014a).

No âmbito da Escola Fernando Nobre, as TDIC existentes por iniciativa da própria comunidade escolar eram sob o formato de blogs, canal no YouTube ${ }^{43}$, Google plus $^{44}$ e Facebook ${ }^{45}$; e, a Plataforma Moodle ${ }^{46}$, em decorrência da parceria da Escola com o Grupo Alph@.

Haviam quatro blogs na Escola: "E.E. Escola Fernando Nobre"47 (2008), sobre atividades escolares gerais; o "Oficina Nobre" 48 (2009), sobre atividades e projetos das oficinas curriculares; o "Jornal Fernando Nobre"49 (2014), para atividade de língua portuguesa; e o Blog da "Sala de Leitura"50 (2013).

\footnotetext{
42 Disponível em: <https://sed.educacao.sp.gov.br>. Acesso em: 13 maio 2016.

43 Disponível em: <https://www.youtube.com/channel/UCFGmTU252P28FSVJi0_wzBw>. Acesso em: 13 maio 2016.

44 Disponível em: <https://plus.Google.com/111889215942693229598>. Acesso em: 13 maio 2016.

45 Disponível em: <https://m.facebook.com/pages/E-E-Fernado-Nobre/224362657762742>. Acesso em: 13 maio 2016.

46 Moodle (Modular Object-Oriented Dynamic Learning Environment) é um software gratuito e livre, que dá apoio à aprendizagem colaborativa e à gestão administrativa e pedagógica de cursos online (FERREIRA, 2010). Página oficial da Plataforma disponível em: <https://moodle.org/>.

47 Disponível em: <http://eefernandonobre.blogspot.com.br/>. Acesso em: 13 maio 2016.

${ }^{48}$ Disponível em: <http://oficinanobre.blogspot.com.br/>. Acesso em: 13 maio 2016.

49 Disponível em: <http://imprensanobre.blogspot.com.br/>. Acesso em: 13 maio 2016.

50 Disponível em: <http://adalribeiro.blogspot.com.br/>. Acesso em: 13 maio 2016.
} 
A Escola foi inserida na Plataforma Moodle em maio de 2015, com a criação do Centro Virtual de Formação Permanente (CFVP), pela Coordenadora do Grupo Alph@ Profa. Dra. Stela C. B. Piconez. O CVFP é um ambiente virtual de formação e atuação dos agentes da Escola (monitores, corpo docente, pedagógico e gestor), com o objetivo de desenvolver a cultura digital na escola, especilamente, para a formação permanente dos professores. A Plataforma é administrada pelo Curso de Extensão da USP - Moodle STOA/USP.

O CVFP foi organizado em tópicos: o primeiro destinado à ambientação dos participantes no ambiente; o segundo direcionado à construção coletiva de Projetos com o Grupo Alph@ e a Escola, com abertura de fóruns de discussão em temáticas inerentes à gestão e docência na Educação Básica; e o terceiro tópico destinado aos conteúdos específicos dos componentes curriculares, com orientações para o trabalho com projetos e para o uso de TDIC nos estudos e pesquisas escolares, como: Parâmetros Curriculares Nacionais, orientações da SE/SP e conteúdos recomendados por membros do Grupo Alph@, inclusive aqueles que foram compartilhados e produzidos nesta pesquisa ${ }^{51}$. O acesso para participação requer uso de senhas cadastradas pelo Moodle STOA/USP e é restrito aos participantes da Escola Fernando Nobre.

As Oficinas de Orientação de Estudos são consideradas na Resolução SE $n^{\circ}$ 6/2016 (SÃO PAULO, 2016a), como componente curricular obrigatório. No Plano Escolar consta que seu objetivo é desenvolver hábitos importantes de organização de estudo em relação às tarefas escolares solicitadas pelas demais disciplinas escolares. Em documentos oficiais expressa a finalidade de "dar condições ao aluno de ler, observar e questionar o mundo, com autonomia progressiva, para ampliar as informações e avançar em seus conhecimentos sobre um tema específico." (SÃO PAULO, 2007b, p. 4).

As Oficinas são definidas anualmente pela Direção da Escola na Diretoria de Ensino de Carapicuíba, conforme a formação, disponibilidade de professores e recursos previstos para cada ano letivo.

A Seção 3.2 apresenta os participantes da pesquisa e os dados indicadores de Letramento Digital encontrado no contexto escolar, na fase inicial da pesquisa.

51 Disponível em: <http://cursosextensao.usp.br/course/view.php?id=264>. 


\subsection{PARTICIPANTES DA PESQUISA E A FLUÊNCIA DIGITAL}

Os dados desta Seção foram obtidos a partir de sondagem diagnóstica realizada com os professores das Oficinas de Orientação de Estudos e com alunos, mediante os Questionários A e B, respectivamente (APÊNDICES E e F). Os questionários tiveram por objetivo caracterizar o perfil tecnológico dos participantes. Além dos dados de identificação na Parte 1, os instrumentos continham na Parte 2 um pequeno inventário para identificar, de forma preliminar, a fluência digital relacionada ao tipo de dispositivo tecnológico, índice de frequência/ausência de uso tipo de atividade que realizavam e os aplicativos que utilizavam (ou não), com o intuito de identificar quais tecnologias digitais adotavam e como as utilizavam.

O Prof. A, responsável pela Oficina de Orientação de Estudos, possui Licenciatura Plena em Pedagogia, pela Faculdade Capixaba de Educação e Administração e pós-graduação lato sensu em Educação Especial pela Educartes, ambas em Vitória (ES). O outro professor responsável pelas Oficinas é o Prof. B, que tem Bacharelado e Licenciatura em Biologia, pela Universidade Paulista e pósgraduação lato sensu em Análises Clínicas, pela Universidade Nove de Julho, na cidade de São Paulo (SP). Com essa formação inicial ambos atendem ao prescrito no inciso VII, do Art. $7^{\circ}$, da Resolução SE $n^{\circ}$ 6/2016, que define as seguintes habilitações/qualificações para atuação nas Oficinas de Orientação de Estudos:

[...] preferencialmente, diploma de Licenciatura Plena em Pedagogia, ou Licenciatura Plena em disciplinas da área de Ciências da Natureza, ou Licenciatura Plena em disciplinas da área de Ciências Humanas, ou Licenciatura Plena em disciplinas da área de Linguagens. (SÃO PAULO, 2016a, p. 1).

A relação com a sala de aula desses dois professores teve trajetórias de formação distintas antes da atribuição de aulas em 2014 na Escola Fernando Nobre.

As primeiras experiências do Prof. A, como docente, foram durante sua vida acadêmica. Após a conclusão do Curso de Pedagogia, em 2011, aos 33 anos, foi trabalhar na Escola Fernando Nobre, como prestador de serviços por nove meses na Secretaria da Escola, e em seguida, atuou com a monitoria na Oficina Orientação de Estudos, pelo Programa Mais Educação (BRASIL, 2010a). Com sua aprovação no Concurso para Carreira do Magistério no Estado de São Paulo assumiu, em 2015, uma sala de aula em outra escola em Cotia (SP), e complementava sua renda na 
Escola Fernando Nobre até 2017, quando assumiu sua segunda classe efetiva, no município de Carapicuíba (SP).

O Prof. B graduou-se em 2008, em Licenciatura em Biologia, aos 30 anos. Iniciou sua experiência como docente em 2014, na Escola Fernando Nobre, por intermédio de uma professora que lhe informara sobre inscrições emergenciais para processo seletivo ${ }^{52}$, permanecendo como contratado na Escola, respeitados os intervalos ${ }^{53}$ que não caracterizem vínculo empregatício com o Estado.

Em 2016, nas Oficinas de Orientação de Estudos, o Prof. A trabalhava com a turma de $6^{\circ}$ ano e as duas turmas de $9^{\circ}$ ano; o Prof. B, com as duas turmas de $7^{\circ}$ ano e as duas de $8^{\circ}$ ano.

Vale notar que a geração dos professores e alunos que frequenta a Escola Fernando Nobre nasceu a partir da década de 1980, contexto no qual as tecnologias digitais já se faziam presentes e, portanto, julga-se que essas lhes sejam familiares. Assim, uma característica típica desses sujeitos é a fluência digital, a conexão com amigos e a possibilidade de acesso à comunicação rápida e a muitas informações, via Internet.

Quanto à aproximação dos professores e alunos às TDIC, os dados estatísticos estão representados graficamente no APÊNDICE O (ver Gráficos 3.1 e 3.2). Em seu conjunto, sinalizam conhecimento de alguns componentes computacionais, comunicacionais, informacionais e multimidiáticos, relacionados às categorias de Letramento Digital (WARSCHAUER, 2006).

Quanto à posse de equipamentos, o Prof. A e o Prof. B declararam possuir celular com acesso à Internet e computador. O Prof. A declarou a existência também de um tablet com Wi-Fi. O Prof. A acessava a Internet em casa e na Escola, o Prof. $B$, somente na Escola.

Com relação às práticas e preferências de acesso à Internet e uso de aplicativos, os professores usavam e-mail dos provedores Gmail e Yahoo; declararam fazer pesquisa nos sites do "Brasil Escola" e "Info Escola", com frequência; o Prof. B costumava fazer downloads de música e vídeos e o Prof. A, de fotos. E para conversas e mensagens instantâneas, os professores usavam o WhatsApp e um deles disse ter

\footnotetext{
52 Definido pela Lei Complementar n 1.093/2009 (SÃO PAULO, 2009).

${ }^{53}$ Período em que os professores ficam sem trabalhar na Rede estadual paulista para poder voltar a ser contratado, a fim de não caracterizar vínculo empregatício. Passou a ser chamado de "duzentena" com a Lei Complementar $\mathrm{n}^{\circ}$ 1.093/2009, pois eram 200 dias (SÃO PAULO, 2009), mas com a Lei Complementar $\mathrm{n}^{\circ} 1.277 / 2015$ esse intervalo passou a ser de 180 dias (SÃO PAULO, 2015a).
} 
usado poucas vezes o Messenger. O Skype e o Hangouts, aplicativos dedicados ao estabelecimento da comunicação instantânea, ambos não os conheciam.

A rede social Facebook foi a declarada como a mais acessada pelos professores. O Instagram apenas o Prof. A fazia uso. E o Twitter, nenhum deles. Ambos declararam não ter o hábito de jogar online.

Os professores afirmaram ter alguma habilidade com o Word e PowerPoint, aplicativos presentes nos Programas do Office, destinados à criação e edição de textos e apresentações, entretanto não declararam habilidade com o Excell.

Quanto ao uso de blogs, os Professores A e B declararam ter acessado a blogs educativos para efetivar leituras de seu interesse. Nunca criaram um blog para uso contexto escolar.

Quanto aos alunos participantes nessa etapa da pesquisa, foram colhidos dados de 46 deles, o que representou $21 \%$ do total de 218 alunos, como já indicado. A faixa etária identificada nessa etapa se concentrou entre 10 e 13 anos.

Em relação à fluência digital, é valido dizer que todos os alunos da escola participam da geração que nasceu com a presença de teclados e do mundo digital.

Do total de alunos, $70 \%$ declararam possuir celulares; $70 \%$ disseram possuir computador ou laptop em casa; e 42\%, tablet. Para 90\%, o acesso à Internet era feito em casa e $10 \%$ acessavam em lan houses ${ }^{54}$, em casa de amigos ou de parentes. E o acesso à Internet na Escola, até aquele momento, não foi indicado por esses alunos.

Quanto ao uso de e-mail, 78\% dos alunos possuíam um endereço ativo, tendo o Gmail como provedor mais usado e 3\% usavam o e-mail da mãe. Vale destacar que $11 \%$ informaram um endereço inexistente, o que foi identificado no momento de sua utilização em sala de aula, posteriormente. Destaca-se aqui como as pesquisas operam muitas vezes com dados declarados pelos informantes, porém inexistentes, a imersão no contexto escolar pode ampliar a aproximação com dados reais.

Realizar pesquisa na Internet era uma prática confirmada para $48 \%$ dos alunos. Vale notar que $52 \%$ dos respondentes declararam que nunca haviam realizado pesquisa na Internet. Entretanto, fazer downloads de fotos, vídeos e áudios no celular eram práticas identificadas como frequente para $86 \%$ deles.

\footnotetext{
${ }^{54}$ Lan House (Local Area Network), ou rede local, é um estabelecimento comercial onde os usuários interessados em ter acesso aos computadores e à Internet podem pagar por um determinado tempo de uso. Trata-se de uma ferramenta no processo de inclusão social também aos alunos de escolas públicas.
} 
A maioria dos alunos fazia uso de algum aplicativo para participação em chats (bate-papo) e uso de mensageiros online, o mais usado era o WhatsApp, com $72 \%$ dos respondentes; em seguida estava o Messenger do Facebook, com 57\%. Para conversas síncronas, o Skype havia sido usado por $46 \%$ desses alunos e o Hangouts, por $14 \%$.

Entre os alunos, o Facebook também era a rede mais usada, $84 \%$ tinham conta ativa. Acesso ao Instagram teve frequência com $51 \%$ dos alunos; e o Twitter com $23 \%$. Quanto ao uso de jogos online, $80 \%$ dos alunos disseram acessar jogos online.

Os Programas do Office eram pouco usados entre os alunos. Mais da metade assinalou não ter qualquer habilidade. Dos 46 alunos, 36\% conheciam o Word, 18\% o PowerPoint e 13\% admitiram conhecer o aplicativo de planilhas, Excell.

Embora a escola possuísse quatro blogs, do total de alunos respondentes, $24 \%$ afirmaram já ter criado um blog, estando $4 \%$ deles inativos; os outros $76 \%$ não eram autores; e, 34\% tinha o hábito de pesquisar por essa mídia.

Uma sondagem preliminar se deu quanto às questões relacionadas ao Letramento Informacional. Uma pergunta versou sobre como se caracterizava uma boa informação na Internet: $30 \%$ dos alunos expressaram dificuldades de entendimento, outros não responderam. Esse fato inspirou a ação que foi implementada com ações de Letramento Informacional.

$\mathrm{Na}$ análise temática das respostas à essa questão foram agrupadas 50 características indicadas, de acordo com a aproximação de significado dos termos e expressões usadas, resultando em uma classificação da pesquisadora, quanto à atratividade, utilidade, amplitude e confiabilidade da informação (Gráfico 3.3).

Gráfico 3.3 - Qualidade da informação, segundo os alunos

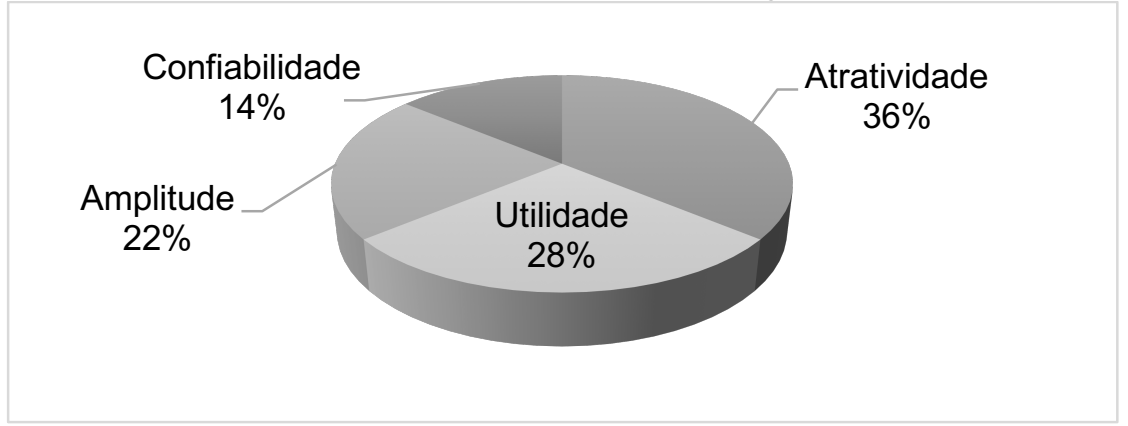

Fonte: Pesquisa da autora (2018) 
As características de uma boa informação mais citadas pelos alunos dizem respeito à atratividade (36\% dos itens), qualidade que expressa interesse por temas agradáveis ou divertidos, como:

- Que tragam só coisas boa. (PEDRO).

- Eu acho que são bons os documentários (eles nunca são muito chatos). (JONAS).

Em segundo lugar, com $28 \%$ dos itens, estiveram características relativas à utilidade, "às coisas da escola" (SAUL), "encontramos tudo sobre lições" (TIAGO), isto é, deve servir para os estudos, para pesquisas escolares. Afirmaram que consideram uma boa informação quando esta consegue:

- Tirar dúvidas escolares e achar o correto de todas as pesquisas. (JAIRO).

- Ter coisas importantes. Para o que estamos estudando (ELIA).

- Falar o que a gente tem que estudar para prova. (MOISÉS).

Em terceiro lugar, com $22 \%$ dos itens, estiveram as características ligadas à amplitude, aquela que apresenta boa explicação, que seja bem detalhada e de preferência "esteja em um só lugar." (MIRIAM).

Por último, com $14 \%$ dos itens, a confiabilidade é requerida pelos alunos, pois sinalizaram que a boa informação deve ser verdadeira. Saul destacou que "a fonte não deve ter assuntos sem sentido, deve ter a prova que é de confiança."

Outra pergunta versou sobre a percepção dos alunos quanto aos riscos que poderiam sofrer ao usarem a Internet. As indicações dos alunos totalizaram 154 itens. Três alunos afirmaram que não sabiam quais seriam os riscos na Internet e outros três disseram não haver risco algum. Restaram 148 itens de ocorrência de respostas (palavras, expressões ou frases), dos quais resultaram da análise temática 56 itens distintos, que foram organizados em cinco classes pela pesquisadora.

As classes dos fatores que podem causar perdas e danos foram: conteúdo veiculado na Internet; perfil psicológico do internauta; e o próprio comportamento do aluno. E as outras duas classes estão ligadas às perdas e danos à integridade do aluno e aos seus equipamentos.

Na contagem das ocorrências distribuídas nas Tabelas 3.1 e 3.2 (APÊNDICE O), dos 148 itens indicados pelos alunos os mais frequentes foram: vírus (23\%), hackers (16\%) e conteúdos impróprios (13\%).

Os fatores menos citados pelos alunos, com percentuais abaixo de $10 \%$ dos itens foram: contato com pessoas perigosas, o próprio comportamento na Internet e as perdas e danos à sua integridade. 
Esses dados foram apresentados na Escola Fernando Nobre, servindo de subsídio às suas futuras intervenções pedagógicas, quanto à problemática da segurança na Internet. Do mesmo modo, conduziram a pesquisadora e os Professores A e $B$ a trabalhar orientações pertinentes aos alunos quanto à questão, de como buscar e selecionar informações com segurança na Internet. No Capítulo 4 estão indicadas as iniciativas da pesquisa nesse sentido.

A Seção 3.3 apresenta uma síntese da primeira etapa da pesquisa, segundo as dimensões categorizadas nas análises temáticas efetivadas, configurando a diagnose do contexto escolar.

\subsection{O CENÁRIO DAS TDIC NA ESCOLA}

O cenário descrito na Escola Fernando Nobre, em especial nas Oficinas de Orientação de Estudos (de 2015 ao primeiro semestre de 2016), revela que embora o uso pessoal e social das TDIC seja presente entre os professores e alunos participantes, o seu uso educativo foi percebido como uma necessidade e um anseio, sendo considerado como fundamental ao trabalho educativo, pois:

- [...] direcionam os alunos de uma forma positiva, como usar as tecnologias a seu favor. (PROF. B).

O Plano Escolar (EEFN, 2013) já havia identificado a "dificuldade para implementar o trabalho pedagógico com uso das mídias", tendo concedido em 2014 o espaço para atuação do Grupo Alph@ e a incorporação desta investigação, com a perspectiva da pesquisa-ação.

Com a análise temática dos dados foram organizadas quatro dimensões de fatores presentes e interdependentes no contexto da Escola Fernando Nobre: infraestrutura; administrativa-pedagógica; didática-pedagógica e pessoal (APÊNDICE L).

A questão da infraestrutura, ligada à inclusão digital nas escolas, tanto na parte física, quanto tecnológica, encontrava-se de maneira precária; a falta de formação permanente de professores para trabalhar com conteúdos didáticos apoiados pelas TDIC e o quadro docente com rotatividade anual, decorrente da contratação de professores, por tempo determinado no Estado, foram fatores que comprometiam vários aspectos do cotidiano escolar, identificados em algumas situações, como: uso não regular de TDIC, inconsistência nas ações didáticas de modo geral e no uso de 
TDIC, por falta de recursos adequados e de formação específica; insegurança docente, tanto para o uso de TDIC em suas aulas, quanto por sua condição instável de trabalho no Estado.

O Prof. B expressava frequentemente sua preocupação com o seu futuro, devido a sua condição de professor contratado, chegando a dizer:

- Já estou de cabelo em pé, só em pensar ficar desempregado com o fim do contrato e entrar em duzentena.

Uma outra situação decorrente da rotatividade de professores contratados é a lotação anual do quadro docente nas disciplinas, o que acarretava descontinuidade do trabalho docente, inclusive nas oficinas curriculares.

Especificamente, quanto à infraestrutura foi unânime a indicação da necessidade de maior número de computadores disponíveis para uso educativo, pois as máquinas instaladas e em funcionamento dificultava o atendimento da demanda da Escola, dado o quantitativo de alunos geral e por turma. Como disse o Prof. A.

- É preciso acesso, quantidade de máquinas disponíveis e espaço.

Havia necessidade de outros recursos tecnológicos, além de computadores, considerado um desafio aos professores, pois era comum ouvir:

- Temos que revezar o datashow [pausa], tem só um na escola. E temos que cumprir o currículo. (PROF. B).

Foi identificada a urgência de mais uma sala de aula e de um espaço amplo para o Laboratório, equipado apropriadamente e com cadeiras suficientes, como expressou o Prof. A:

- Imagina [pausa] Dentro numa salinha pequena, a metade senta e a outra
metade fica no tatame, no chão. Fica muito complicado usar os
computadores com a classe agrupada dessa forma!

Uma alternativa encontrada pelos professores era a divisão da turma em dois espaços, o Laboratório e o Refeitório, ficando o professor com a atenção dividida. E mesmo o professor subdividindo a turma em grupos para trabalhar com os computadores, em torno de dois a três alunos por máquina, ainda assim se tornava difícil o trabalho pela limitação do espaço e de insuficiência de cadeiras, fazendo com que vários alunos sentassem no chão para fazer suas atividades.

A preocupação com as quedas de energia elétrica na Escola foi detectada como causa da insegurança dos professores, pois:

- Até o motorista da pirua sabe que acaba luz aqui direto. (PROF. A).

Foi apontada como constante a dificuldade de acessos à Internet, dada a potência e velocidade geralmente fraca, com frequentes quedas de sinal. A escola 
não tem verba para as condições necessárias para manter profissional técnico habilitado para manutenção e acompanhamento de tais problemas.

Quanto à formação permanente, o Prof. A, durante seu exercício profissional no Estado, participou de um curso de formação oferecido pela SE/SP durante 60 horas em seu período probatório, e segundo ele, "sem qualquer conteúdo sobre tecnologias" e o Prof. B cursou Robótica pela SE/SP, quando fez robôs com materiais recicláveis, sem ter colocado em prática, posteriormente. E reforçou a reclamação de que "a Secretaria parece desconhecer o dia a dia das escolas para propor esse tipo de formação."

Nessas circunstâncias, os professores, muitas vezes, responsabilizam-se pela própria formação permanente e levam consigo para outros espaços aquilo que vão aprendendo voluntariamente com seus pares e em outras oportunidades nas escolas. Uma realidade constatada nas pesquisas TIC Educação 2014, 2016 (CGI.br, 2015b, 2017).

Alguns excertos extraídos de suas manifestações evidenciam essa situação:

- A prática e a exigência faz eu mesmo me preparar todos os dias. Só que o tempo para conhecer novas informação que é insuficiente [pausa] Talvez seja nosso maior desafio! (PROF. B).

- Fátima, é bom que você me ensina a fazer e eu aproveito lá na minha outra escola em que dou aula também! (PROF. A).

Vale notar que durante a permanência da pesquisadora na Escola não foi realizada formação aos professores oferecida pela SE/SP, mas apenas palestras do Grupo Alph@ e de outros convidados diretamente pela equipe gestora.

Uma decorrência da alta rotatividade de professores de um ano letivo ao outro era a constante atualização do cadastro dos inscritos no CVFP, implicando em descontinuidade do processo de formação docente.

A escola sempre contou com esforços dos membros do Grupo Alph@ e a receptividade dos agentes da Escola, configurando um eterno recomeçar a cada ano letivo. As dificuldades de infraestrutura tecnológica e a incompatibilidade de tempo dos professores para os HTPC comprometiam as exíguas oportunidades de formação presencial. E embora o CVFP tenha sido apresentado ao corpo docente em várias oportunidades em HTPC e em atendimentos individuais pelos pesquisadores do Grupo Alph@, a participação dos agentes da Escola de 2015 a 2016 não foi o esperado, tanto pelos pesquisadores, como pela Direção das Escola. 
Entretanto, não admitiram a hipótese de desistir de utilizar o Moodle, pois acreditavam que compartilhar suas experiências poderia reduzir a falta de interações na escola entre os professores. Estes sinalizaram a exigência de maior tempo para acesso, criticavam as condições de infraestrutura precárias e o pouco tempo disponível para a atividade de ambientação e estudo nessa plataforma, que requer continuidade para o processo de formação de professores (APÊNDICE B).

A Coordenadora pedagógica reiterou que os professores têm dificuldades para postarem suas experiências no Moodle, afirmando que:

- Eles não conseguem publicar lá, entrar, publicar, é complicado; esquecem a senha e manifestam dificuldade para o acesso.

A dimensão administrativa-pedagógica, além da rotatividade anual de professores, apresentou fatores de gestão de processos, tempos, espaços e recursos escolares, tais como: horário do laboratório; planejamento didático conjunto; uso de celulares na Escola e da Wi-Fi como alguns dos impedimentos para os quais lutam para encontrar alternativas e soluções, nem sempre acolhidas.

Como a Escola atua com sete turmas anualmente, mas só dispunha de seis espaços físicos apropriados para sala de aula, o Laboratório era usado diariamente por uma das turmas em sistema de rodízio, sem planejamento didático para uso dos computadores e sem organização de horário. Tal situação dificultava o processo de ensino-aprendizagem, devido ao uso inadequado do espaço, ou seja, sem o uso dos computadores, deixando os alunos mal acomodados e ávidos por usarem as máquinas. Como expressa o Prof. A:

- Numa salinha pequena [Laboratório] por mais que eu me esforce eu não consigo controlar os alunos [pausa] Não sei mais o que fazer no Laboratório com esses meninos!

O planejamento didático entre os pares era comprometido pelo tempo dedicado no HTPC a pautas diversificadas e atentas aos compromissos burocráticos, exigidos pela Direção da escola e pelo desencontro docente. A Coordenadora pedagógica manifestou sua preocupação com esse fato, "pois nos horários que estão fora de sala, atendem em outras escolas, e quando podem cumprir o HTPC nesta escola, nem sempre há coincidência de horário conjunto. Fica difícil a orientação pedagógica!"

As condições existentes na Escola reforçavam 0 trabalho docente individualizado, comprometendo o planejamento coletivo e a consequente realização de projetos pedagógicos e estudos interdisciplinares com apoio de TDIC. Havia necessidade de liberação do uso de celulares para atividades educativas, proibido 
durante o horário de aula, por medida restritiva ${ }^{55}$. Ao mesmo tempo, a Direção não disponibilizava a senha do Wi-Fi (SÃO PAULO, 2007a, 2008). Dessa forma, o trabalho com aplicativos em aparelhos móveis em atividade educativa pelo professor ou pesquisador do Grupo Alph@ também ficava restrito aos que possuíam smartphones ou tablets, com plano de Internet próprio e na dependência de liberação do uso e da Wi-Fi pela Direção. A liberação para uso dos celulares contou com a elaboração de Plano Aditivo incorporado ao Plano Escolar e aprovado pela Diretoria de Ensino de Carapicuíba, elaborado pela Profa. Dra. Stela C Bertholo Piconez, em conjunto com o Corpo gestor e professores da escola. Além de ter sido aprovado e autorizado pela Diretoria de ensino que jurisdicionava a Escola Fernando Nobre.

$\mathrm{Na}$ dimensão didática-pedagógica, além da carência da formação docente permanente, encontram-se fatores relacionados à percepção/ação das novas formas de ensinar/aprender; aos conhecimentos e habilidades didáticas; uso educativo das TDIC; aos recursos didáticos e produção discente.

Dentre as dificuldades observadas no planejamento didático, havia necessidade de desenvolver estudos focados em competências e habilidades, sendo esses conceitos ainda confusos entre o corpo docente, pois:

- A falta de estudo dos professores dificulta desde o planejamento até as práticas e estratégias da sala de aula. (COORDENADORA PEDAGÓGICA).

A queixa principal da Coordenadora Pedagógica recaiu sobre a necessidade de formação permanente dos professores, alegando que "a formação inicial deles e as orientações do início do ano letivo não atribuíram ênfase às competências."

Essa situação foi observada pela pesquisadora entre os Professores A e B, que compartilharam sobre suas dúvidas que envolvem o planejamento didático, tanto na elaboração de seus planos, quanto prática de sala de aula. Como disse o Prof. A:

- As habilidades eu realmente não coloquei [pausa] E essa visão [de habilidades] é que eu queria ter, isso que eu queria ter ajuda. O HTPC deveria servir pra essa formação, mas são dedicadas aos serviços de Secretaria da escola, questões de notas dos alunos ou preenchimento de formulários enviados pela Diretoria de Ensino. Apesar das orientações de cima, eu ainda não sei as diferenças entre habilidade e competências e nem compreendo o ajuntamento de várias disciplinas em áreas interdisciplinares. Veja você, nem conseguimos nos reunir professores pelos tais eixos curriculares!

55 A Lei $n^{\circ} 12.730 / 2007$, regulamentada pelo Decreto $n^{\circ} 52.625 / 2008$, proibia os alunos de utilizarem telefone celular nos estabelecimentos de ensino do Estado durante o horário das aulas (SÃO PAULO, 2007a, 2008). Em 2017, com a Lei $n^{\circ} 16.567 / 2017$, o artigo $1^{\circ}$ Lei $n^{\circ} 12.730 / 2007$ passou a vigorar com a seguinte redação: "Ficam os alunos proibidos de utilizar telefone celular nos estabelecimentos de ensino do Estado, durante o horário das aulas, ressalvado o uso para finalidades pedagógicas (SÃO PAULO, 2017a). 
As aproximações com as TDIC observadas e explicitadas pelos professores (ver Seção anterior) em maior expressão correspondiam ao uso social do WhatsApp e Facebook. Para atividades didáticas era utilizado o Word apenas para produção dos planos de ensino. As pesquisas docentes na Web eram frequentes em dois sites "Info Escola" e ao "Brasil Escola".

As tecnologias registradas nos planos didáticos eram filmes, datashow e pesquisa na Internet. Nas aulas eram comuns as cópias do quadro de giz, trabalhos manuscritos e desenhos. Tais contatos, mesmo que insipientes e ocasionais puderam ser compreendidos como dados que caracterizam a fluência digital existente entre eles.

Os alunos manifestaram uso de variadas redes e mídias sociais, assim como os games, o que sinaliza atração pelas tecnologias. No momento da coleta de dados nas salas de aula houve boa receptividade. As redes sociais também são muito utilizadas como o WhatsApp e Facebook.

Os professores da Escola Fernando Nobre não dispunham de orientação para uso efetivo da "Plataforma Currículo+", fomentada pela SE/SP; inclusive a sua existência ainda não era do conhecimento da maioria dos professores, dentre eles, o Prof. A e o Prof. B. E o ambiente virtual da Plataforma "Professor 2.0" também não estava em utilização pelos professores.

A participação nas mídias da Escola era modesta, não havia continuidade nas postagens nos blogs, exceto o da Oficina Nobre, que era constantemente atualizado pela Profa. Josete Zimmer.

A dimensão pessoal envolve fatores referentes ao próprio participante, a saber: sua condição socioeconômica; sua disponibilidade para aprender; colaboração, sentimentos e motivações para fazer uso das TDIC:

- O novo é muito complicado, até pra nós mais jovens é difícil aceitar o novo. (PROF. B).

- Não tenho internet e nem wifi. Meu celular é apenas para contato com os familiares. (PROF. B).

Havia por parte de professores e alunos disposição para ensinar/aprender com TDIC e abertura para a colaboração com seus pares, contudo as condições estruturais da Escola e as condições materiais e de tempo dos professores comprometiam não só o planejamento, mas a própria formação e atuação na sala de aula com as tecnologias digitais, que eram atraentes para os alunos. 
Antes da Ação implementada foram identificadas a existência de elementos indicativos de Letramento Digital explicitadas pelas diversas categorias discriminadas por Warschauer (2006).

Quanto ao Letramento Computacional, a maioria dos alunos sabia ligar e desligar o computador; mais da metade teve dificuldades iniciais para acessar e-mail; a maioria conseguia acessar sites de busca na Internet, salvar vídeos, fotos e músicas, e enviar arquivos por e-mail e em redes sociais. Os professores ligavam e desligavam o computador; o Prof. B esquecia o endereço e senha do e-mail; ambos tinham dificuldade para acessar e seguir blogs; acessavam sites de busca na Internet, salvavam documentos no computador e em pendrive; e compartilhavam arquivos apenas por e-mail.

Quanto ao Letramento Informacional, os alunos buscavam informações na Internet de forma livre, selecionavam informações sem critérios definidos, não salvavam e nem sempre anotavam as referências localizadas. Os professores buscavam informações na Internet sem utilizar operadores de busca e palavraschave; selecionavam informações sem estabelecer critérios; salvavam, imprimiam ou arquivavam informações, no entanto, nem sempre anotavam as referências selecionadas.

Quanto ao Letramento Multimidiático alguns alunos criavam e editavam com alguma limitação no Word e apresentações no PowerPoint, com uso de texto verbal e inserção básica de imagens. Os professores criavam e editavam documentos no Word, com limitações na formatação e as apresentações no PowerPoint faziam com uso de texto verbal e inserção básica de imagens.

Quanto ao Letramento Comunicacional, os alunos faziam poucos comentários em blogs e usavam Facebook socialmente. Alguns alunos faziam comentários em redes sociais sem atenção às regras de comportamento na rede, ou sem dar atenção à correção gramatical do texto. Apenas o Prof. A criou um blog pessoal; os dois professores faziam leitura em blogs, mas não comentavam; e usavam Facebook socialmente.

O conhecimento da realidade escolar, a manifestação de interesse da equipe gestora da Escola e dos participantes da pesquisa em avançar no uso educativo das TDIC foi essencial para que a Ação implementada acontecesse de forma colaborativa.

Tal sondagem diagnóstica apontou para a construção de conhecimentos que pudessem contribuir com a formação dos professores para o uso de TDIC com 
intencionalidade educativa e a aprendizagem dos alunos quanto ao estudo e a pesquisa, sob a perspectiva do Letramento Digital.

Uma questão instigante à pesquisadora foi sistematizar o conteúdo da Ação e definir estratégias para "ampliar, estender, refinar, atualizar, reconfigurar [...] a rede de significados [que os professores] já trazem, valorizando as relações que são percebidas, que são enraizadas no contexto cultural que vivenciam." (MACHADO, 2015, p. 161). Para tanto, o conhecimento da trajetória profissional dos professores e seus conhecimentos manifestos no dia a dia na Escola foi fundamental.

Em síntese, na Escola Fernando Nobre, mesmo que algumas tecnologias digitais estivessem presentes na vida dos escolares e respondentes da pesquisa, possuíam apenas uso social de comunicação e não se encontravam atreladas ao trabalho pedagógico (APÊNDICE B).

Os professores identificaram por inúmeras vezes que não havia formação sobre seu uso. Por fim, foi percebido que o uso das TDIC com fins pedagógicos era uma expectativa de todos na Escola.

O espaço do Laboratório de Informática era utilizado inadequadamente. $O$ número de computadores era insuficiente para uma demanda efetiva de adoção de TDIC, e o uso de equipamentos móveis, como os celulares, também apresentava suas restrições. Estes problemas estruturais poderiam ser resolvidos em instâncias superiores com a construção de mais uma sala de aula, a compra de mais computadores para os alunos e a liberação de rede Wi-Fi para fins educativos. E no âmbito da Escola, a situação poderia ser amenizada se os professores, mobilizados por uma coordenação pedagógica permanente, usassem os computadores de fato, de maneira planejada, sistemática, embora permanecendo a dificuldade do número reduzido de máquinas e cadeiras, e a consequente divisão da turma em dois ambientes. Para contribuir com a resolução dessa questão já havia sido solicitado, em 2014, o apoio da Profa. Dra. Stela C. B. Piconez para elaboração de um Projeto de Desenvolvimento de Cultura Digital para compor, após sua aprovação, o Plano Global da escola.

Existiam quatro blogs e alguns recursos tecnológicos disponíveis na Escola Fernando Nobre, mas sem incorporação às atividades escolares.

O Centro Virtual de Formação Permanente, CVPF, na Plataforma Moodle, para interação e formação com o Grupo Alph@, foi pouco aproveitado, embora 
disponibilizasse continuamente material de estudo e provocações cognitivas por parte dos pesquisadores da FE/USP.

Em 2017, por determinação da SE/SP, a Escola perdeu o direito de ter um agente que fizesse a coordenação dos processos didático-pedagógicos, por não apresentar o critério de ter 300 alunos ou mais. Inexistia na Escola Fernando Nobre um projeto coletivo ou mesmo um planejamento didático regular entre os pares, o que era um desafio à Coordenação pedagógica. Compreende-se que a presença efetiva dessa categoria profissional pode contribuir para o fortalecimento dos processos educativos, inclusive o de apropriação das TDIC, e a sua ausência associada à falta de um projeto da Escola e à rotatividade docente anual, restringe a consolidação da cultura digital na instituição, que tem reiniciado anualmente a formação docente com a chegada de novos professores, fato ocorrido ao longo dos anos com a presença do Grupo Alph@.

Tudo isso limitava a oportunidade da prática educativa com TDIC de forma coletiva e interdisciplinar. Se houvesse um projeto pedagógico com inclusão digital independente da permanência dos seus agentes escolares, os esforços poderiam ser otimizados e poderia haver uma continuidade nas conquistas dos alunos.

A falta de um projeto pedagógico que integre as TDIC no currículo escolar; uma carga horária docente e um horário que possibilite a formação permanente; o trabalho coletivo; a formação adequada às necessidades escolares; a dedicação e a continuidade do trabalho na mesma escola podem ser considerados wicked problems ${ }^{56}$.

Embora as limitações e desafios na realidade escolar como fatores que dificultam a efetividade do uso das TDIC nas Oficinas, foi possível acreditar que um design pedagógico, apoiado pelas tecnologias digitais, contextualizado e experimentado no cotidiano na Escola poderia trazer importantes mudanças nos tradicionais espaços e ações de ensino e aprendizagem. O Letramento Digital não surge nas escolas e nas práticas de ensino espontaneamente. Antes, é fruto não apenas do contato com equipamentos e aplicativos digitais, mas da consequência de ações educativas planejadas com intencionalidade educativa na seleção e uso das TDIC.

56 Wicked problems, tradução aproximada para um problema ultra complexo. São problemas incompletos, contraditórios e com requisitos mutáveis, para os quais as soluções são difíceis de serem identificadas, por sua interdependência. Foi conceitualmente sugerido por Horst Rittel e por M. Webber. 
O Capítulo 4 apresenta o Design pedagógico implementado, que teve o objetivo de criar oportunidades de uso das TDIC disponíveis, sob a perspectiva do Letramento Digital, consequência do entendimento da análise das condições existentes no contexto escolar, nas Oficinas de Orientação de Estudos. 


\section{O DESIGN PEDAGÓGICO COM SUPORTE DAS TDIC}

Os estudos, documentos e a revisão das referências reiteram que se vive em um mundo de mudanças e que as TDIC estão presentes na vida de professores e alunos. Tal fato não pode ser desconsiderado para não se constituir exclusão do contexto social, ou favorecê-la.

$\mathrm{Na}$ função social da escola, repensar o planejamento das ações pedagógicas sempre foi uma condição sine qua non. Diante do avanço acelerado das tecnologias digitais, o contexto escolar requer planejamento pedagógico, continuamente, o que confere à pesquisa, complexidade. Além da obsolescência da infraestrutura tecnológica da escola e ausência de formação docente permanente, o Letramento Digital, enquanto um fenômeno relativamente novo, demanda um tempo para observação e identificação, e, por ser complexo, requer um tempo de maturação para que, além do seu entendimento, seja construído de forma consistente.

Diante desses aspectos, e em sua decorrência, surgiu a oportunidade de construção de vivências novas, relacionadas à temática no contexto pesquisado com a imersão na realidade escolar.

Os referenciais conferidos pelas leituras sobre Letramento, Letramento Digital e Letramento Informacional sustentaram a abordagem metodológica na pesquisa-ação, com intervenção nas práticas educativas nas Oficinas de Orientação de Estudos. Seu objetivo foi buscar a familiaridade, convivência e conhecimento sobre o tema, em ações compartilhadas com uso de algumas TDIC pelos professores e alunos.

Os questionamentos e a hipótese que nortearam esta investigação sobre o Letramento Digital no contexto escolar possibilitaram a criação cooperativa do Design pedagógico, que buscou contemplar intencionalidade educativa na seleção e uso das TDIC.

Tendo em vista a inclusão digital no âmbito geral, o Letramento Digital na escola básica, também "implica repensar elementos como a formação de seus profissionais, a estrutura física das escolas, sua proposta pedagógica, políticas educacionais, dentre outros - os quais precisam ser modificados para atender a essa nova demanda formativa" (ARAÚJO; GLOTZ, 2014, p. 3) para que a apropriação das TDIC possa auxiliar as possibilidades de expressão e comunicação, que favoreçam o desenvolvimento dos alunos para uma sociedade democrática (MORAN, 2006). 
Uma certeza havia no percurso desta investigação, a de que "os recursos tecnológicos por si sós, não garantem melhora no aprendizado e na qualidade da educação", mas o uso planejado das TDIC, com intencionalidade educativa, pode auxiliar na "transformação da escola em um instrumento de inclusão digital.". Outra certeza foi a reflexão norteadora para a atuação na pesquisa de forma integrada, articulada e contextualizada, voltada para o desenvolvimento de "ações em que os alunos [e professores] possam explorar esses recursos em sua totalidade, utilizandoos na consecução das mais diversas atividades no processo de aprendizagem." (ARAÚJO; GLOTZ, 2014, p. 3).

Este Capítulo contempla um dos objetivos específicos desta pesquisa, o estudar, criar, implementar e acompanhar as práticas educativas apoiadas por ações integradas às TDIC fortalecidas com o desenvolvimento de conhecimentos, habilidades e atitudes inspirados pelo conceito de Letramento Digital e seus desdobramentos.

Descreve a fundamentação do Design pedagógico construído na pesquisa-ação no contexto escolar.

A seguir Seção 4.1 apresenta a opção inspiradora do Design pedagógico, assim como da abordagem metodológica adotada junto aos professores e alunos na proposta de desenvolvimento do Letramento Digital.

\subsection{ABORDAGEM METODOLÓGICA NA AÇÃO IMPLEMENTADA}

A concepção teórica que sustenta a pesquisadora sobre planejamento e projetos pedagógicos no contexto escolar tem como referencial os estudos realizados ao longo de sua trajetória profissional tais como: César Coll (1994; 2010); Hernández (1998); Libâneo (2010); Schön (2000); Vasconcellos (2010); Veiga (2008); Zabala (2010); Zabala e Arnau (2010), dentre outros, além dos teóricos Freire (1987, 1996, 2000, 2003), Piaget (1999) e Vigotsky (2007), que fundamentam tais estudos e têm apontado caminhos seguidos para a construção de uma educação emancipatória, responsável e ética.

Portanto, para o planejamento da ação desta pesquisa foram considerados alguns aspectos apontados como importantes na elaboração de projetos pedagógicos, como: a definição das concepções da escola com relação à educação, 
suas finalidades, valores, necessidades e expectativas referentes ao uso de TDIC; a elaboração de um diagnóstico quanto ao uso de TDIC na realidade escolar; a definição de um plano de ação contextualizado; e, a construção coletiva do design.

Para definição do marco referencial, diagnóstico e programação da ação (construção e implementação de um design pedagógico) foi necessária a imersão da pesquisadora na realidade escolar pois:

\begin{abstract}
O conhecimento e a análise crítica do contexto no qual os problemas se manifestam são muito importantes para identificar suas causas, que poderão ser encontradas no interior da própria escola, na estrutura da sociedade e na interação entre a escola e o contexto social global. (FUSARI, 1990, p. 52).
\end{abstract}

Realizado o diagnóstico, foi definido o Letramento Digital para orientar a prática educativa com uso das TDIC, com o pressuposto de que esse referencial poderia trazer contribuições aos processos de ensinar e aprender com as TDIC, tendo em vista a necessidade e interesse manifestado pela escola, quanto ao desenvolvimento de sua cultura digital.

Segundo Veiga (2008, p. 23), "a escola persegue finalidades", e a Escola Fernando Nobre tinha clareza sobre seus objetivos e suas finalidades em relação ao seu desejo de ampliar a cultura digital.

Compreendeu-se o movimento provocativo na pesquisa-ação e seu o caráter dialético. Não se tratava apenas de uma pesquisa de interesse acadêmico, mas um reconhecimento mútuo de promover mudanças na escola. Assim, surgiram novas questões e respostas, que levaram a novas interrogações. Uma delas era, como desenvolver a cultura digital referenciada pelos conceitos de Letramento Digital? Existe um know how, um padrão, ou precisaria ser construído?

A segunda questão norteou o planejamento da ação para que se articulasse aos demais projetos escolares e assim pudesse alcançar os objetivos da pesquisa e os da escola. E esse movimento fez com que os participantes refletissem sobre a intencionalidade educativa da escola (VEIGA, 2008).

Foram realizados grupos focais a partir de alguns questionamentos, dentre eles: que ideal temos para esta escola? O que significa desenvolver uma cultura digital em que professores e alunos sejam sujeitos do próprio desenvolvimento? Em que consiste "letrar-se" digitalmente? Quais as condições ideais para desenvolver uma prática educativa com tecnologias digitais? Como deve se dar uma educação voltada para a era digital? Como tornar a escola na era digital um espaço de mudanças, e 
com suas contribuições, reforçar uma escola democrática? Que princípios devem orientar a prática pedagógica com Letramento Digital?

Com essas reflexões percebeu-se que a pesquisa-ação se constituía em um espaço de aprendizagem promissor, na medida em que desencadeara um processo de reflexão ainda maior sobre a escola e sobre os efeitos do projeto voltado para as suas necessidades e emergência de Letramento Digital. Foi o ponto de partida para a ideia de criação, planejamento, implementação e acompanhamento da ação, ou seja, um saber fazer com a participação de professores e alunos, fundamentado e com base nas necessidades da escola. Isto os remeteu a pensar nas intenções educacionais de uso e de apropriação das TDIC.

A princípio predominou o espaço participativo sobre o crítico, porque estavam emocionalmente integrados; as vivências na pesquisa demandavam adesão e foram amplamente registradas em diários de campo (APÊNDICE B).

O senso de responsabilidade com a convivência de um ano letivo na Escola Fernando Nobre inspirou dimensões valorativas e éticas, consideradas na criação da ação configurada em um design pedagógico para uso das TDIC.

O advento das tecnologias digitais amplia as possibilidades de comunicação, que sob a perspectiva de diferentes linguagens, coloca em xeque a escrita, tradicionalmente usada na escola, independente das suas condições contextuais.

O que se pode observar é que o "domínio do sistema alfabético de escrita não garante que sejamos capazes de ler e produzir todos os gêneros de texto." (ALBUQUERQUE, 2007, p. 17). Isto permite questionar se a escola se apoia na escrita como linguagem preferencial para ensinar, desenvolver o Letramento Digital pode levar a um melhor desempenho dos alunos nas demandas de domínio da Língua Portuguesa? O apoio do professor, a partir das diferentes linguagens, sob a perspectiva do Letramento Digital, pode oportunizar o desenvolvimento de um trabalho reflexivo sobre os dados, informações e conhecimentos veiculados na Web?

Independentemente da escola, os alunos têm liberdade para ler e escrever seus textos. Um dos aspectos que chama a atenção é que, com as TDIC, os alunos precisam ter autonomia, criticidade e poder para usar as mídias e redirecionar seus acessos na Web em benefício de seus interesses (ARAÚJO; GLOTZ, 2014). Então, qual seria o papel da escola, do professor quanto às habilidades para usar tecnologias digitais e navegar pela Web? O que deve ser planejado para seu uso continue estimulando os alunos? Segundo essas autoras, atividades que estimulem a 
criticidade, a manifestação de opiniões e a argumentação são algumas das habilidades que a escola deve desenvolver.

Com essas considerações, para ampliar tais habilidades foi estudado um conjunto de ações que culminou no Design pedagógico, desenvolvido em um processo de construção participativa com os professores e alunos.

Foi um desafio à pesquisadora, considerado o complexo repertório de conhecimentos necessários para "relacionar a linguagem dos meios de comunicação à educação, nos processos didático-pedagógicos, demonstrando domínio das tecnologias de informação e comunicação para o desenvolvimento da aprendizagem", conforme determinado nas Diretrizes Curriculares Nacionais para formação inicial em nível superior e para a formação continuada de professores (BRASIL, 2015, Art. 8, inciso $\mathrm{V}$ ). Além dessa determinação legal de um repertório teórico-prático, há que se considerar que a necessidade e o interesse pelo conhecimento sobre as tecnologias digitais têm surgido entre pesquisadores e, sobretudo, por parte dos professores, como revela a pesquisa TIC Educação 2014 (CGlb.br, 2015b).

Shulman $(1986,1987)$ já indicava na década de 1980 a existência de três categorias de conhecimento docente: o conhecimento do conteúdo específico, conhecimento pedagógico geral e conhecimento pedagógico do conteúdo. De acordo com esse autor, o conhecimento específico relaciona-se ao conhecimento da área a ser ensinada, corresponde a conceitos, fatos, teorias etc., de uma determinada área de conhecimento e àqueles referentes a sua construção. É um tipo de conhecimento imprescindível à docência, porém não é suficiente para garantir que algo seja ensinado e aprendido. O conhecimento pedagógico geral equivale às teorias, princípios e formas de ensinar e aprender, conhecimento dos alunos, dos contextos educacionais, de outras disciplinas, do currículo, dos fins, metas e propósitos educacionais, bem como de seus fundamentos filosóficos e históricos.

O conhecimento pedagógico do conteúdo interliga o conhecimento pedagógico ao conhecimento do conteúdo, não simplesmente como uma relação, mas uma transformação do objeto estudado (conteúdo) para compreensão do aluno. Em outras palavras, é uma representação do tema de estudo, a fim de torná-lo compreensível ao aluno. O professor constrói esse conhecimento no exercício da docência e continuamente vai sendo enriquecido por outros conhecimentos. Equivale à construção própria do professor na ação de transformar o que aprendeu para ensinar, 
fazendo uso, por exemplo, de analogias, demonstrações, exemplificações, ilustrações e explanações.

Shulman (1986), a seu tempo, não abordou o conhecimento tecnológico, já que não discutiu a tecnologia relacionada ao aspecto pedagógico e ao conteúdo, pois na época da sua primeira discussão sobre a base de conhecimento docente, as questões que envolviam tecnologias não estavam em primeiro plano, na medida em que estão [permanecem] hoje (MISHRA; KOEHLER, 2006).

Uma contribuição teórica inspiradora foi encontrada nos estudos sobre o modelo explicativo da ação docente, de Mishra e Koehler (2006, 2009), acerca da necessidade de integração dos diferentes tipos de conhecimentos.

A integração das tecnologias no ensino foi retomada de Shulman por Mishra e Koehler (2006). Esses autores estudaram um modelo explicativo da ação docente, relacionando o ensino à tecnologia na formação de professores, com a inclusão do novo elemento na base dos conhecimentos necessários à docência, ou seja, o componente tecnológico.

Mishra e Koehler (2006, 2009) definem o Modelo como conhecimentos pedagógicos dos conteúdos da tecnologia, conhecido como TPACK ${ }^{57}$ (Technological Pedagogical Content Knowledge), uma interseção complexa de três pares de componentes: o PCK, o TCK e o TPK.

O PCK - Pedagogical Content Knowledge (Conhecimento Pedagógico do Conteúdo) possibilita ao professor uma forma de ensinar própria, adequada à compreensão de conteúdos diversos pelos alunos; o TCK - Technological Content Knowledge (Conhecimento do Conteúdo Tecnológico) possibilita a compreensão da relação do conteúdo da tecnologia ao conteúdo específico a ser ensinado, facilitando, por exemplo, compreender o que a tecnologia permite fazer, em termos de sua funcionalidade para ensinar um conteúdo específico; o TPK - Technological Pedagogical Knowledge (Conhecimento Pedagógico-Tecnológico) possibilita a compreensão de como a tecnologia pode ser usada no processo de ensinoaprendizagem (MISHRA; KOEHLER, 2006, 2009).

A articulação desses conhecimentos tem sido estudada no Brasil, a exemplo de Nakashima (2014) e Piconez et al. (2014), que observam a integração de todos os conhecimentos nos planejamentos de cursos a distância, presenciais e no modo

57 Informações disponíveis em: <http://tpack.org>. 
blended learning (combinação de práticas presenciais e a distância). Ressaltam que a integração desses conhecimentos requer formação docente para o domínio de recursos e estratégias, tendo em vista a construção de conteúdos conceituais, atitudinais e procedimentais, com os estudantes, de modo contextualizado e com apoio de tecnologias que potencializem a experiência do conhecimento.

A aproximação teórica com o Modelo TPACK iluminou a compreensão da pesquisadora sobre a prática docente apoiada por TDIC. E implicou avanço do uso de recursos digitais e capacitação docente para o entendimento da complexidade de ações que demonstram conhecimentos e habilidades didático-pedagógicas, importantes para o Letramento Digital na escola.

Por isso, o Design pedagógico criado para a ação de desenvolver atividades escolares sob a perspectiva do Letramento Digital, considerou os seguintes pressupostos:

a) existe um conhecimento pedagógico do conteúdo sobre como planejar para ensinar determinado conteúdo e requer a reflexão sobre o próprio conteúdo (o que, por que, para que e como e quando, que recursos utilizar e como avaliar); b) conhecer o conteúdo tecnológico dos recursos das TDIC é necessário para definir quais delas são mais adequadas à aprendizagem de um determinado conteúdo; e

c) existe um conhecimento pedagógico sobre a seleção e uso das tecnologias que requer descobrir quais habilidades elas podem desenvolver, previstas em qualquer planejamento de ensino, como suporte ao ensino e à aprendizagem.

Cabe destaque à contribuição do conceito de intencionalidade educativa, com Piconez et al. (2014), os quais identificaram características importantes a serem consideradas no planejamento de episódios-aula com apoio das TDIC; sua seleção envolve diferentes questões de acessibilidade e consequente usabilidade pedagógica dos equipamentos e aplicativos. Isto é, a intencionalidade educativa de uma tecnologia está presente quando se atribui ao seu uso, competências sobre ensinar e aprender. Para a autora:

O Letramento Digital vem sendo caracterizado pela identificação de oportunidades de aprendizagem apoiadas pelas tecnologias digitais, sob formato tutelado ou como autoestudo; porém implica também na formação criativa e crítica do uso pedagógico [intencionalidade educativa] dos recursos tecnológicos, sabendo quando e por que utilizá-los em sala de aula; no reconhecimento de abordagens inter, intra e transdisciplinares; nos modos de leitura, de escrita e de produção de conteúdos em situações que envolvem 
textos, imagens, sons, códigos variados, no formato de hipertexto, em ambientes virtuais. (PICONEZ et al., 2014, p. 326, negrito nosso).

Diante dessas contribuições surgiram, na fase de planejamento da ação, algumas possibilidades, tais como oferecer cursos presenciais ou a distância, oficinas e palestras, entre outras. Todavia, optou-se por uma ação no próprio espaço de atuação dos professores, durante a prática educativa. Ou seja, nas Oficinas de Orientação de Estudos, nas atividades dos professores com seus alunos, correspondendo às expectativas da Escola por uma ação no próprio local de trabalho e em seu cotidiano.

$\mathrm{Na}$ criação do Design pedagógico, os conhecimentos dos professores e alunos foram considerados como ponto de partida e requisito para o fortalecimento de práticas educativas que tivessem o suporte das TDIC, respeitando-se o momento de construção de sentidos e significados. Também foram contemplados os objetivos de recuperação da alfabetização e letramento, que a Escola apresentava como compromisso assumido após a análise dos índices de leitura e escrita dos alunos auferidos pelas provas externas.

O uso das TDIC no Design pedagógico ampliou a interação direta dos professores e alunos na prática, apoiada por recursos e aplicativos, que favorecem aspectos relacionados ao movimento dialógico e integrado.

Para isso, o uso das TDIC foi incentivado não com uma forma bancária para simples reprodução de conteúdo ou como um repositório de dados e informações, mas como estímulo à criatividade de professores e alunos. E no acompanhamento dado aos professores e alunos foram consideradas as habilidades de se expressar e compartilhar ideias e informações sob concepção e prática pautadas na dialogicidade, sem a qual não há comunicação, tampouco educação (FREIRE, 1987, 1996).

As TDIC, dada a sua "importância como artefatos culturais na mediação da aprendizagem e do desenvolvimento." (PICONEZ et al., 2014, p. 5), foram agregadas às práticas docentes e discentes como suporte relevante de interação.

A atribuição de intencionalidade educativa às tecnologias escolhidas auxiliou os professores no entendimento de que elas podem enriquecer o "potencial de expansão e de distribuição de conhecimentos", que são construídos coletivamente no contexto escolar (PICONEZ et al., 2014, p. 5).

A Seção 4.2 apresenta o Design pedagógico criado na Ação Implementada nas Oficinas de Orientação de Estudos, com destaque para o Ciclo de Ações Educativas 
apoiadas por TDIC, construído em imersão na prática escolar. Descreve o conjunto das ações integradas às tecnologias digitais fortalecidas com o desenvolvimento de valores, conhecimentos e habilidades referenciadas pelo conceito de Letramento Digital e seus desdobramentos. Indica o movimento do Ciclo, embasado nas ideias de Machado $(2008,2015)$, relacionadas às competências do professor.

\subsection{O CICLO DE AÇÕES EDUCATIVAS APOIADAS POR TDIC}

O Design pedagógico desenvolvido envolveu a complexidade até aqui identificada quando se trata do uso das TDIC, que objetiva desenvolvimento de cultura digital no contexto escolar.

A elaboração do Design pedagógico seguiu o Ciclo de Ações Educativas apoiadas por TDIC e foi concebido a partir da rede de significações construída pela pesquisadora, a partir de seus estudos no exercício de sua docência, nas disciplinas da pós-graduação na FE/USP, na revisão de trabalhos científicos e na pesquisa bibliográfica sobre o objeto investigado e, especialmente, na interação com os professores e alunos na Escola. A organização dos seus estruturantes didáticos do Design encontra-se sintetizada no APÊNDICE N.

O movimento desse Ciclo sugeriu sinergia de ações docentes e discentes em vários momentos do processo de ensino-aprendizagem, considerada a intencionalidade educativa atribuída às tecnologias escolhidas. Esse Ciclo articulou conhecimentos e habilidades específicas para a busca, seleção, planejamento, organização, construção, informação, comunicação e avaliação dos novos conhecimentos, referentes aos conteúdos das Oficinas de Orientação de Estudos.

$\mathrm{Na}$ rede de significações, envolvendo os conhecimentos e habilidades docentes, as articulações didáticas foram estimuladas com envolvimento das ações de: mapear relevâncias, construir narrativas, tecer significações e mediar relações, apresentadas por Machado $(2008,2015)$.

A Figura 4.1 ilustra a composição desse Ciclo, configurado em um fluxo flexível, não-linear e contínuo das ações integradas às competências docentes. $E$ por consequência, teve seus impactos nas ações da pesquisadora e nas habilidades dos alunos. 
Figura 4.1 - Ciclo de Ações Educativas apoiadas por TDIC

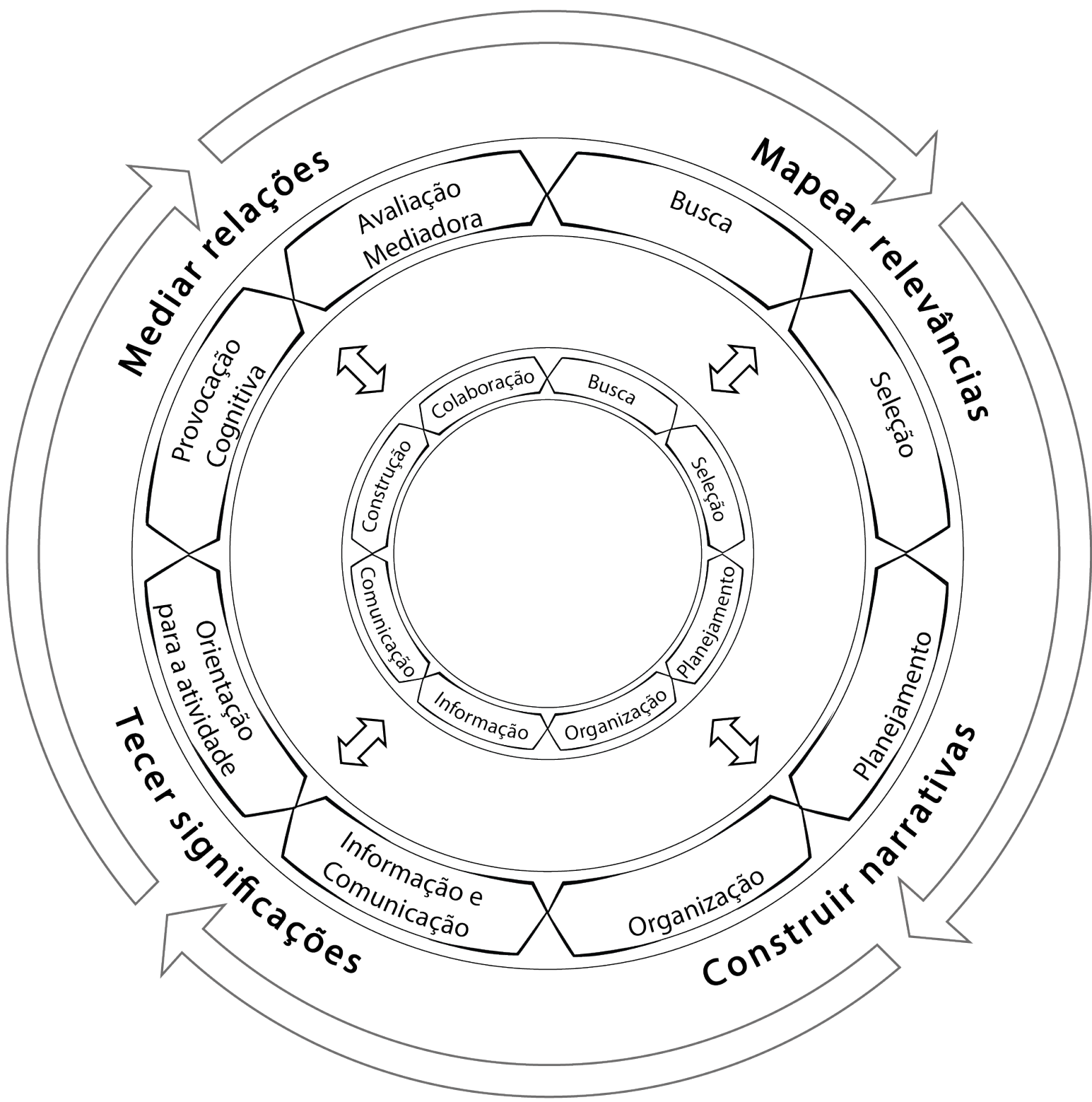

Fonte: Pesquisa da autora (2018), com base em Machado $(2008,2015)$

A Figura 4.1 indica que a ação de mapear relevâncias, ou seja, a que define e organiza dados e informações consideradas relevantes ao que se pretende ensinar (MACHADO, 2015) está imbricada na busca e seleção das fontes. Esta tarefa consiste na consideração não apenas de encontrar um site ou o formato de mídia a ser apresentado aos alunos. Mapear requer reflexão para os objetivos de aprendizagem que se quer desenvolver; requer planejamento, categorização e organização. 
$\mathrm{Na}$ Web podem ser localizados qualquer tipo de dados e informações e a Internet favorece o acesso, a comunicação e a construção (individual e compartilhada) de conhecimento, que no entendimento de Machado (2008, p. 50) significa:

[...] construir uma grande rede de significações, onde os 'nós' seriam os
conceitos, as noções, as ideias, em outras palavras, os significados; e os fios
que compõem os nós seriam as relações que estabelecemos entre algo em
que concentramos nossa atenção e as demais ideias, noções ou conceitos;
tais relações condensam-se em feixes, que, por sua vez, articulam-se em
uma grande rede.

A ação de mapear relevâncias é fundamental ao planejamento e organização da construção de narrativas didático-pedagógicas, operando como uma curadoria de conteúdos com critérios de busca e seleção de fontes (dados, informações e conhecimentos), como recursos auxiliares ao alcance da aprendizagem esperada.

$\mathrm{Na}$ pesquisa, as ações (buscar e selecionar) tiveram como objetivo iniciar os professores, e, posteriormente os alunos, nas questões relacionadas ao Letramento Digital com desdobramento para o Letramento Informacional.

Para o Letramento Informacional foi relevante considerar os argumentos de Dudziak (2003, p. 23) quando ressalta que a informação é um conceito complexo e abrangente e que o significado do Information Literacy "vai além da soma de suas partes (informação e literacy)."

A finalidade do Letramento Informacional na sociedade contemporânea, segundo Gasque (2010, p. 86), é a adaptação e socialização dos indivíduos, mediante as capacidades de:

[...] determinar a extensão das informações necessárias; acessar a informação de forma efetiva e eficientemente; avaliar criticamente a informação e a suas fontes; incorporar a nova informação ao conhecimento prévio; usar a informação de forma efetiva para atingir objetivos específicos; compreender os aspectos econômico, legal e social do uso da informação, bem como acessá-la e usá-la ética e legalmente.

Como citado anteriormente, em estudos de Soares (1998/2014, p. 72), letramento é "o que as pessoas fazem com as habilidades de leitura e escrita, em um contexto específico, e como essas habilidades se relacionam com as necessidades, valores e práticas sociais."

Nesse sentido, na era de construção de conhecimentos via tecnologias digitais, o Letramento Informacional torna-se imprescindível no contexto escolar. Diante da abundante oferta de informações na Web, a escola deve incentivar e esclarecer sobre a busca e seleção de fontes com qualidade, com reflexão acerca da informação obtida e a consequente construção de conhecimentos. 
Logo, no Design pedagógico criado, para a ação de mapear relevâncias foram discutidos aspectos relacionados ao Letramento Informacional, desdobramento do Letramento Digital, tais como: os cuidados e a necessidade de se ter indicadores descritivos para escolha mais aproximada de informações para as pesquisas escolares; saber identificar a veracidade de notícias; recorrer a sites de produção científica; reconhecer e respeitar os direitos autorais; dar atenção à segurança na Internet, dentre outros aspectos.

As questões relacionadas aos direitos autorais foram pauta de encontros com os professores, sendo destacada a importância da menção dos autores das informações localizadas na Web nas atividades escolares (trabalhos dos alunos e material didático usado pelos professores), a fim de evitar plágios, pois conforme Atheniense (2013, p. 1), sem uma legislação específica ${ }^{58}$ "muitos pensam que qualquer conteúdo disponibilizado na rede passa a ser público, podendo ser livremente utilizado." No entanto, as obras intelectuais literárias, artísticas e científicas presentes na Web "não perdem sua proteção e, portanto, não podem ser utilizadas sem prévia autorização."

Como as Oficinas de Orientação de Estudos na Escola Fernando Nobre não possuíam conteúdos específicos vinculados à uma determinada área e sem interação com as demais disciplinas do currículo, com a finalidade de mapear relevâncias, uma outra orientação realizada com os professores esteve vinculada à curadoria ${ }^{59}$ dos conteúdos, tal qual exposto por Rojo e Barbosa (2015). Isto implicou em ações de seleção, organização, hierarquização e apresentação de conteúdos/informações. Esta dimensão tomou grande parte das discussões no planejamento das atividades das Oficinas, porque havia o objetivo de apresentação dos trabalhos dos alunos em meio virtual.

Foi considerada a função social da escola quanto ao seu papel orientador de chamar atenção dos alunos sobre as inúmeras informações e conteúdos na Internet, que, como explica Rojo e Barbosa (2015), estão dispersas, difusas, algumas vezes complementares, outras, contraditórias, e sujeitas a diversas interpretações, que

\footnotetext{
${ }^{58}$ A Legislação sobre Direitos Autorais, em vigor, encontra-se na Lei nº 9.610/1998 (BRASIL, 1998), mas não aborda as questões no ambiente virtual.

59 Curadoria é um conceito que tem origem na área das artes e está sendo cada vez mais usado para designar ações e processos próprios do universo das redes (ROJO; BARBOSA, 2015).
} 
precisam ser reordenadas para que se tornem inteligíveis e possam promover (novos) sentidos.

Como destaca Pérez Gómez (2015, p. 29), a curadoria de conteúdos representa um desafio para os professores por causa da necessidade de transformar informações desorganizadas e fragmentadas em conhecimentos, isto é, em "corpos organizados de proposições, modelos, esquemas e mapas mentais que ajudem a entender melhor a realidade."

Nesse aspecto, o Design pedagógico ofereceu oportunidades para que os professores exercitassem o papel de curadores de conteúdos, não mais determinados pelos livros didáticos, mas, com o suporte da Internet. Foram propostas atividades de analisar material disposto na Web, fazer escolhas, selecionar conteúdos em diversas mídias, organizar e sugerir fontes de pesquisa aos alunos.

Para orientar e fortalecer a ação de buscar dados e informações na Internet foram preparadas uma apresentação com slides e a videoaula "Pesquisando na Internet" sobre a busca orientada, com uso adequado de palavras-chave e operadores lógicos ${ }^{60}$, apropriados para refinar e especificar os resultados da busca.

E considerando os dados da sondagem sobre a percepção dos alunos quanto à adequação das informações acessadas pela Internet (ver Seção 3.2), para orientar e fortalecer as ações de selecionar uma informação foram definidos cinco critérios (5 ás), que emergiram da reflexão sobre como reconhecer a relevância de uma informação, quais sejam: ser apropriada - corresponde a um objetivo, conveniente e adequada; ser autêntica - tem a localização ou autoria comprovada, apresenta a origem, proveniência, legítima, verdadeira; ser ampla - apresenta riqueza de dados, farta, abrangente, vasta; ser atraente - provoca interesse, agradável, cativa pela qualidade; ser atualizada - contem modificações, novas formas e correções.

A Figura 4.1 sinaliza que um Design pedagógico para construir narrativas evidencia ações de planejamento e organização das aulas, que resultam da atividade de curadoria realizada, cumprindo o papel de servir de suporte para a construção dos significados, posto que "preparar uma aula é construir uma narrativa pertinente", afirma Machado (2015, p. 170).

Para fortalecer a ação de planejar na Oficinas foi sugerido uma análise sobre os planos já existentes. O objetivo foi incentivar a incorporação das TDIC nas aulas,

\footnotetext{
${ }^{60}$ Detalhes sobre operadores de busca disponíveis em: <http://revistas-hisa.bvs.br/help/operadores.htm>.
} 
dando atenção às suas implicações em cada um dos estruturantes didáticos (objetivos, conteúdos conceituais, procedimentais e atitudinais, recursos didáticos, metodologia de ensino e de avaliação e referências), destacando a importância e a necessidade de clareza na orientação e atenção aos alunos em como usufruir do aporte tecnológico.

Para fortalecer a ação de organizar os conteúdos selecionados para as Oficinas, os professores foram orientados a identificar a autoria no material reproduzido; produzir textos informativos aos alunos; e, organizar as informações com apoio das TDIC. Foi oferecido o apoio da pesquisadora na organização de recursos digitais para estimular a criação dos professores, tanto em encontros presenciais semanais, quanto em recursos online (ver Seção 2.2.2).

A Figura 4.1 indica as ações docentes de tecer significações e mediar relações, que ao serem inseridas no Ciclo em atividades planejadas para as Oficinas foram retomados os requisitos apontados por Gasque (2010, p. 86) para os indivíduos em processo de Letramento Informacional. Enfatizando-se nessas ações as habilidades de "avaliar criticamente a informação e a suas fontes; incorporar a nova informação ao conhecimento prévio; usar a informação de forma efetiva para atingir objetivos específicos."

A ação de mediar relações, que consiste em aproximar a informação dos alunos, instala relações entre os significados (MACHADO, 2008, 2015).

A conexão de significações e de múltiplas redes (relações) não está mais restrita aos livros didáticos e materiais tradicionais. Existe uma materialização digital e online que pode ser encontrada no ciberespaço nas formas de hipertextos, aplicativos de mensagens, em redes sociais, em ambientes virtuais variados, dentre outros. Por isso, o Design pedagógico procurou contemplar também as articulações efetivadas pelos professores e alunos, compreendendo que não existem encadeamentos únicos e "sempre é possível imaginar uma diversidade de caminhos para articular dois nós/significados." (MACHADO, 2015, p. 161).

Para a informação e comunicação dos conteúdos aos alunos, orientação para as atividades discentes, provocação cognitiva e avaliação mediadora, a escolha dos professores foi respeitada. Houve opção pela interface do blog, pois a Escola Fernando Nobre já possuía quatro iniciativas e com pouco aproveitamento e participação. Essa decisão considerou que o uso dessa mídia com intencionalidade educativa em um componente curricular nuclear, além de facilitar a interação com os 
demais blogs da Escola, poderia incentivar a criação e acompanhamento de blogs de alunos; potencializar o compartilhamento de informações e produções dos professores e alunos, e o fortalecimento da cultura digital escolar.

Vale considerar que as práticas formais e informais de comunicação se tornam um referencial na produção e ampliação dos novos sentidos de comunicação dos sujeitos em formação (SOARES, 1996).

Segundo Zimmer (2012, p. 20), os blogs adotados com abordagem sociointeracionista e em perspectiva dialógica fazem parte de uma arquitetura comunicacional ampliada e "uma das possibilidades de aprendizagem colaborativa, na medida em que sua construção e uso estimulam a interação entre seus autores."

Com esse entendimento, o blog pode favorecer e estimular a aprendizagem dos alunos, a prática da leitura e da escrita, o estímulo à construção dos textos; e, como consequência, consolidar o Letramento, conforme estudado por Soares e outros autores já referenciados. $\mathrm{O}$ uso do blog, como outro gênero textual trabalhado nas escolas, pode incentivar os alunos na compreensão de que pode utilizá-lo para se expressar socialmente, inclusive como requer a legislação educacional $(\mathrm{KOCH}, 2007$; MARCUSCHI, 2004).

O blog foi então considerado como um suporte mediador de conhecimentos nas Oficinas. A autoria e coautoria foi encorajada para que esse aplicativo se constituísse em um espaço de construção e compartilhamento de saberes e experiências entre os envolvidos. Para tanto, foi criado como um ambiente virtual de ensino e aprendizagem para interação e colaboração, convergência e organização dos conteúdos das Oficinas de Orientação de Estudos e foi assim denominado: Blog Pesquisa Nobre (APÊNDICE P) ${ }^{61}$. O objetivo de sua criação foi disponibilizar aos leitores informações, orientações, a fim de "contribuir para a construção de conhecimentos e desenvolvimento de habilidades e atitudes necessárias às pesquisas escolares e à navegação em ambiente virtual", cooperando no desenvolvimento do Letramento Digital e cultura digital na Escola (EEFN, 2016).

A decisão pela tecnologia do aplicativo Blogger se deu por outras três razões: a experiência anterior na escola desde 2008; as suas características de acessibilidade e o modo de administração da tecnologia.

${ }^{61}$ O Blog está disponível em: <http://pesquisanobre.blogspot.com.br>. 
Pelo seu caráter dinâmico, flexível, responsivo, versátil, o Blogger serviu ao Design pedagógico dadas as possibilidades para organização didática dos conteúdos, inserção de links de sites de interesse, de blogs dos alunos e de conteúdos em diversos formatos digitais, construção e publicação de conhecimentos, interação da comunidade escolar e como suporte para a avaliação da aprendizagem.

A administração do aplicativo é simples e independente, e agiliza a construção do seu conteúdo, do desenvolvimento e acompanhamento das postagens e comentários, sem demandar serviços de terceiros para a postagem ou qualquer outro procedimento no blog.

Foram criados tutoriais pela pesquisadora com o passo a passo para acesso e criação de postagens. E com o objetivo de fortalecer a informação, comunicação e orientação sobre os cuidados das postagens no Blog, foram feitas recomendações sobre o formato e a linguagem; explicitação sobre as informações e tarefas discentes; elaboração de atividades com resolução de problemas e com oportunidades para colaboração, criatividade, construção e comunicação do conhecimento; especificação clara de objetivos e critérios.

Para orientar e fortalecer a ação de provocar cognitivamente (PICONEZ, 2004; PICONEZ et al., 2014), os professores foram estimulados a interagir nas postagens e comentários no Blog; a apresentar e fundamentar aspectos das novas informações pesquisadas; a avaliar as manifestações dos alunos; incentivar o surgimento de novos significados, argumentos e ideias; perceber questões em estudo, sob a perspectiva de diferentes leituras etc. Os professores foram incentivados a serem provocadores cognitivos, como "uma espécie de arquitetos que acompanham percursos e cenários de aprendizagem na construção significativa de conhecimentos." (PICONEZ et al., 2014, p. 324), tendo sempre em vista a intencionalidade educativa da incorporação das TDIC afinada com as demandas do currículo escolar.

Ainda conforme a Figura 4.1, para fortalecer a ação de avaliar, os professores foram estimulados a acompanhar as manifestações dos alunos nos comentários postados no Blog e nas atividades propostas nessa mídia. O processo de avaliação foi ampliado por considerar mais a "troca de mensagens e significados, um processo interativo, dialógico, espaço de encontro e de confronto de ideias entre educador e educando em busca de patamares qualitativamente superiores de saber." (HOFFMANN, 2001, p. 112). 
Ao trabalhar com os professores acerca dos conteúdos didáticos e tecnológicos, envolvidos no Ciclo, foi fundamental o entendimento do movimento e articulação dos elementos constitutivos para a construção de novos posicionamentos e/ou significados das ações docentes e discentes quanto ao Letramento Digital.

A construção do significado pretendido se efetiva por meio de uma narrativa, ou seja, de um planejamento pertinente, não arbitrário, com sentido, no qual os conteúdos são mapeados (com a busca e seleção de relevâncias), tecidos (com as relações de significados) e mediados pelo professor (com a aproximação aos alunos). (MACHADO, 2008). Diante dessas considerações, o Blog abriu maiores possibilidades de compartilhamento das aprendizagens e das avaliações com o protagonismo dos próprios alunos.

Quanto às ações discentes com TDIC, o Ciclo compreendeu além da orientação da busca segura e seleção de dados e informações na Internet; estratégias de planejamento e organização dos estudos e trabalhos com TDIC; os cuidados com a informação, comunicação e colaboração na construção de conhecimentos veiculados no blog das Oficinas ou em outra forma de exposição (Figura 4.1).

Os professores trabalharam diretamente com os alunos e contaram com apoio da pesquisadora nas ações e nos conteúdos envolvidos no Ciclo, estudados durante os encontros de formação para o uso das TDIC sob a perspectiva do Letramento Digital com intencionalidade educativa.

Para a busca e seleção de informações foram usados os mesmos conteúdos e recursos já trabalhados com os professores, com maior destaque ao Letramento Informacional.

As ações discentes para o planejamento, organização, informação, comunicação, colaboração na construção dos conhecimentos nas pesquisas escolares foram trabalhadas pelos professores a partir das orientações básicas adotadas na Escola; e para a apresentação de trabalhos escolares com TDIC foram utilizados os recursos didáticos produzidos pela pesquisadora (APÊNDICE N).

As apresentações dos alunos foram avaliadas pelos professores quanto à busca e seleção das informações; planejamento e organização da estrutura do trabalho, utilização de textos verbais com ilustrações e hipertextos; cuidados com a linguagem para favorecer a leitura e a compreensão do tema estudado; seleção de informações relevantes; indicação das fontes, especialmente para auxiliar esta ação foi produzida uma videoaula "Como fazer referências de pesquisa da Internet". Houve ainda 
orientações sobre a construção colaborativa de slides no Google Drive e o compartilhamento dos arquivos.

A colaboração entre professores e alunos foi continuamente incentivada. Contribuíram com a redação e edição dos textos e hipertextos, presencialmente com valorização do letramento dos alunos e/ou por meio da computação em nuvem (cloud

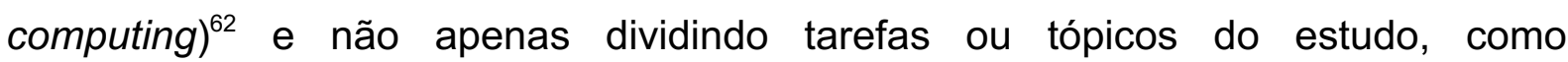
rotineiramente eram os trabalhos em grupos.

Os conhecimentos e habilidades computacionais, informacionais, multimidiáticas e comunicacionais na utilização dos equipamentos e acesso à Internet foram estimulados no processo de uso das TDIC disponíveis na Escola no período da investigação no cotidiano das Oficinas.

Nas Oficinas foram trabalhados com os alunos: 1. conhecimentos, habilidades e atitudes para o uso responsável de equipamentos e aplicativos; 2 . conhecimentos e habilidades para buscar adequadamente e selecionar com qualidade dados e informações na Internet, atitudes crítica, de segurança e ética na utilização da informação; 3. conhecimentos, habilidades e atitudes para o uso criativo e inovador com diversas mídias e aplicativos digitais, que possibilitam o planejamento, organização, comunicação e informação do conhecimento produzido; 4. conhecimentos e habilidades para a produção em diversos gêneros digitais, interagindo com outrem e fazendo uso social do texto; 5. construção, colaboração, e avaliação do conhecimento; e 6. habilidades de compreensão de textos e hipertextos e demais recursos digitais.

Foi constatado que na ambiência comunicacional escolar surgem novas possibilidades de expressão e comunicação online. Entretanto, tudo depende do movimento comunicacional e pedagógico (intencionalidade educativa) dos sujeitos envolvidos para que se consiga organizar, relacionar e co-criar conhecimentos com finalidades de aperfeiçoamento das aprendizagens e habilidades previstas.

Para a pesquisadora, a tarefa de conceber, articular e acompanhar o Ciclo de Ações Educativas apoiadas por TDIC tornou-se cada vez mais complexa, sendo necessário estudar e planejar formas de trabalho com apoio colaborativo. Nesse

62 Cloud Computing, nome dado em alusão à nuvem, por ser um conceito referente à tecnologia que permite o acesso a programas, arquivos e serviços, produção, armazenamento e compartilhamento de arquivos pela Internet sem a necessidade de instalação de programas ou armazenamento de dados nos equipamentos utilizados. 
sentido, a construção de conhecimento precisava ser um processo de tessitura em rede, atrelada à perspectiva do Letramento Digital.

Formar os professores das Oficinas revelou a escassez de investimentos no contexto escolar. Não se tratava de transpor conteúdos e resultados de produção acadêmica. Os processos de formação docente carecem de formação continuada e, para a docência com suporte das TDIC, fez-se necessária, a instituição pontual de um design contextualizado.

O Capítulo 5 apresenta a organização dos dados obtidos pela vivência no contexto escolar em apoio ao desenvolvimento da cultura digital e as análises realizadas a partir das categorias dimensionadas. 


\section{LETRAMENTO DIGITAL: CONTRIBUIÇÕES DO DESIGN PEDAGÓGICO}

O teor deste Capítulo corrobora a hipótese focalizada no movimento de desenvolvimento desta investigação, expressa em termos de seu objetivo geral que contemplou as contribuições do Letramento Digital no contexto escolar e alternativas estratégicas que contemplem intencionalidade educativa. Os objetivos específicos foram registrados nos capítulos anteriores, isto é, elaborar um quadro comparativo do contexto político-administrativo-pedagógico e tecnológico na escola-campo, para compreender as influências e contribuições durante o período de intervenção; constatar a presença de Letramento Digital e a fluência digital dos professores e alunos participantes da pesquisa; estudar, criar, implementar e acompanhar as práticas educativas apoiadas por ações integradas às TDIC fortalecidas com o desenvolvimento de conhecimentos, habilidades e atitudes inspirados pelo conceito de Letramento Digital e seus desdobramentos; e mapear, narrar, tecer e mediar relações do manifestado e do percebido em ações apoiadas por TDIC.

Reitera-se o pressuposto anteriormente enunciado de que o Letramento Digital pode referenciar ações de formação docente em suas práticas educativas integradas com TDIC. E que de fato, não deve ignorar a complexidade da rede de significações que movimenta o contexto escolar, e enquanto pesquisa não pode ignorar o que vai descobrir no seu percurso.

O continuum possibilitado pela pesquisa-ação assegurou o desenvolvimento da interpretação crítica dos dados, criando condições para revisar conhecimentos anteriores e gerar subsídios de reflexão para continuidade dos estudos. Tais reflexões compõem as conclusões da tese.

A estrutura deste Capítulo revestiu-se de complexidade na construção de sua narração. Foi estabelecida reflexão permanente, no sentido de estabelecer um diálogo das dimensões teóricas revisadas sobre o tema com o contexto escolar pesquisado. Expõe os resultados advindos da imersão na Escola Fernando Nobre e denota relações do percebido e o manifestado em ações de Letramento Digital. Os dados foram originados nos Questionários C, D e E (APÊNDICES G, H e I), observação participante, diários de campo, no grupo focal, além de pesquisa documental nas TDIC utilizadas. 
A ação implementada permitiu registrar tanto os desafios presentes no contexto escolar como foi possível identificar nas dimensões infraestrutura, administrativapedagógica, didática-pedagógica e pessoal mudanças significativas no processo como um todo (APÊNDICE L).

Inicialmente, a Seção 5.1 apresenta as reflexões sobre o movimento do Letramento Digital no Design pedagógico nas Oficinas de Orientação de Estudos, dinamizado pelo Ciclo de Ações Educativas apoiadas por TDIC (Figura 4.1); na sequência, na Seção 5.2, reitera os desafios encontrados no contexto escolar e, finalmente, na Seção 5.3, encontram-se os resultados compreendidos como aspectos essenciais à temática, bem como inspiram a continuidade do estudo.

\subsection{MOVIMENTO NAS OFICINAS COM O DESIGN PEDAGÓGICO}

As estratégias viabilizadas contemplaram conhecimentos e habilidades de caráter tecnológico (uso de equipamentos e de aplicativos acessados pela Internet); habilidades de caráter pedagógico (seleção de mídias para conferir intencionalidade educativa; planejamento e organização compartilhada de informações e conteúdos, capacidade de argumentação, dentre outros); e, habilidades atitudinais contempladas pelo Letramento Informacional (tratamento da informação, pensamento reflexivo e crítico, respeito aos princípios éticos à diversidade de opiniões e valores). Essas estratégias comprovaram a complexidade referenciada pelos estudos sobre o tema.

A construção do Design pedagógico em um processo de ação-reflexão-ação, referenciado pelo Letramento Digital e seus desdobramentos possibilitou 0 desenvolvimento de competências e habilidades dos professores e dos alunos, como resultado prático da Ação implementada pela pesquisadora (Figura 5.1).

O movimento do Ciclo de Ações Educativas apoiadas por TDIC estimulou o desenvolvimento do Letramento Digital contextualizado (Figura 5.1).

Para a realização busca e seleção de informações na Internet foram utilizados sites de busca de conteúdos, além dos recursos localizados na Web, como hipertextos, áudios, vídeos e imagens todos presentes nas demais ações do Ciclo.

Especificamente na comunicação entre a pesquisadora e os professores foram utilizados os seguintes recursos digitais: o e-mail, a Plataforma Moddle, o Facebook, 
o WhatsApp, o Hangouts; e o Google Drive (Docs, Slides e Forms) para interação e colaboração, sobretudo nas ações de planejamento e organização.

Nas ações envolvidas no planejamento, organização, informação, comunicação, construção, orientação para a atividade discente, colaboração, provocação cognitiva e avaliação os recursos utilizados pelos professores e alunos foram os editores de texto, vídeo e de apresentações (Word, PowerPoint, Google Docs, Slides, Animoto), PDF, o Google Forms, o Skype e o Blog.

Figura 5.1 - Ciclo de Ações Educativas apoiadas por TDIC no Design pedagógico referenciado pelo Letramento Digital

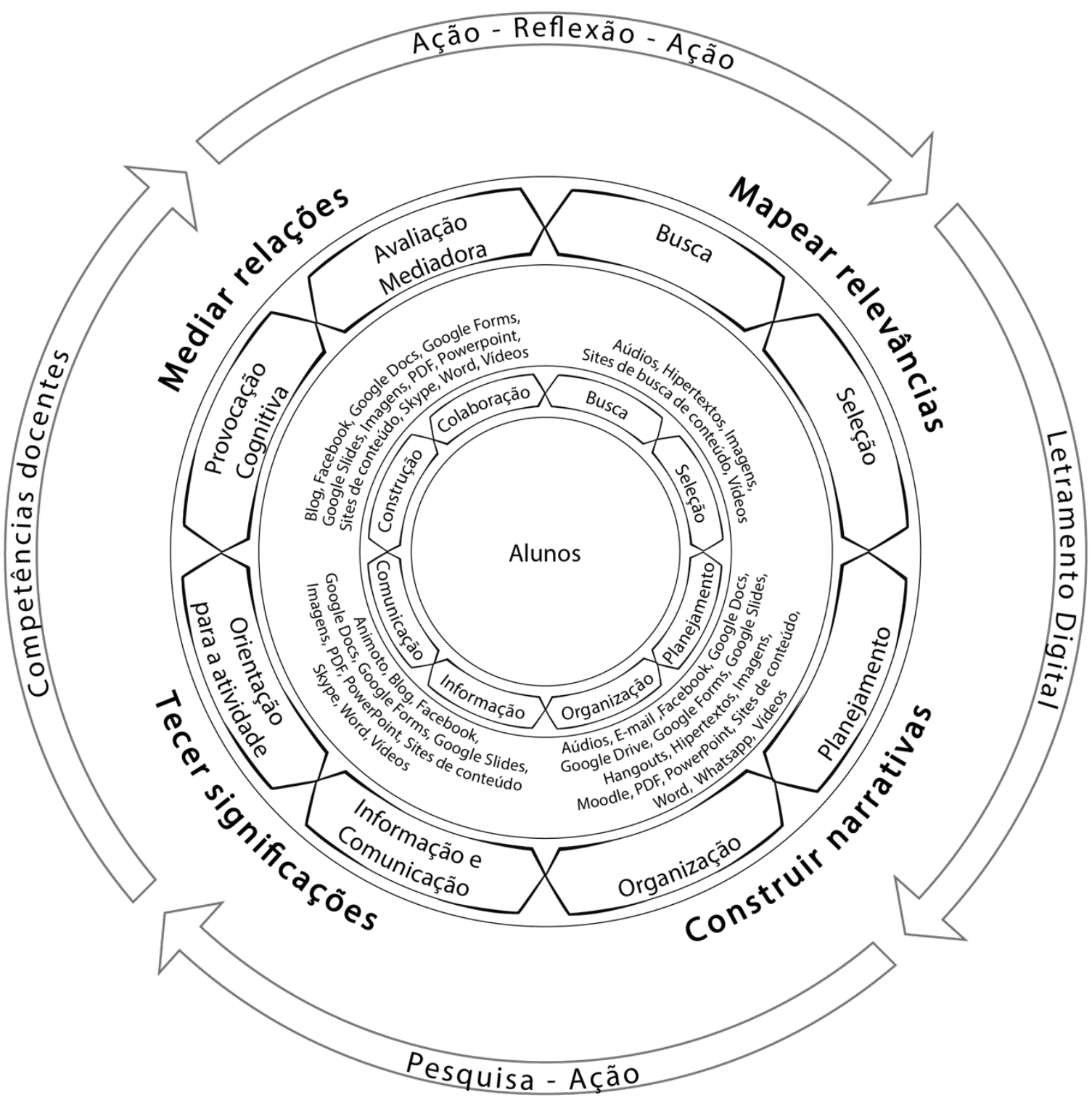

Fonte: Pesquisa da autora (2018) 
Durante a pesquisa, as ações mobilizadas pelo Ciclo de Ações Educativas apoiadas por TDIC (Figuras 4.1 e 5.1) permitiram perceber a ampliação das práticas tradicionais de leitura e de escrita. Foi de fato um momento privilegiado para identificar que elas conduziram a um estado diferente daquele conduzido pelas práticas de leitura e de escrita usuais na escola (SOARES, 2002). Esse novo estado foi identificado entre os participantes em suas manifestações, nos trabalhos com TDIC, nos registros escritos nas mídias e nos instrumentos de coleta de dados.

A produção da escrita na tela nos trabalhos escolares e em mensagens de alunos e professores possibilitou a criação de hipertextos. Foi observado que esse novo espaço trouxe mudanças significativas, que apareceram nas formas de interação entre os professores e os alunos, entre os alunos como produtores de textos, com os conhecimentos construídos coletivamente nas Oficinas. Tais interações demonstraram consequências sociais, cognitivas e discursivas, que extrapolaram os limites físicos da escola e se configuraram como um estado de Letramento Digital, como enfatizado por Soares (2002).

As categorias de Letramento Digital, tratadas por Warschauer (2006) como computacional, informacional, multimidiático e comunicacional, também foram observadas na investigação de forma integrada. Diante do exposto, foram nítidas as ações consideradas como Letramento Computacional, com a aproximação do conhecimento e domínio de uso das TDIC experimentadas nas práticas docentes (Moodle, Facebook, WhatsApp, Hangouts, Skype, Google Drive, Word, PowerPoint e o $B \log )$.

O Moodle foi acessado pelos professores com pouca frequência e os comentários com postagens mais raros, justificados pela falta de tempo declarado por eles, além dos desafios de ausência de infraestrutura tecnológica. Eram comuns suas justificativas nos grupos focais:

- Sabe, não tenho mais computador em casa; a rede de Wi-Fi é ruim e o tempo para postar no Moodle não existe. Na escola, a sala de computadores está ocupada com aulas normais. Não podemos retirar o professor de lá [pausa] Pelo celular é impossível! (PROF. B).

O Facebook, usado socialmente pelos professores, foi uma alternativa para veicular vídeos, fazer provocações cognitivas e para o exercício de uso dessa TDIC como um recurso a mais a serviço da formação docente. Inicialmente, tiveram um pouco de dificuldade para acessar o grupo fechado, como disse o Prof. A:

- Eu sou uma negação com Face! Os alunos navegam fácil [pausa] Acho que vou aprender com eles! 
A participação dos professores era sempre justificada por alguma dificuldade, mas ao longo das ações implementadas, já usavam confortavelmente.

O WhatsApp foi sempre utilizado pelos professores para conversas espontâneas, troca de ideias, agendamentos de encontros, envio de material e links. Seu uso, em contexto social, não apresentava outra dificuldade a não ser a instabilidade da velocidade da Internet em seus celulares:

- A Internet está caindo, por isso parei de falar com vc. A Internet é péssima, não consigo abrir e olhar. Quando pretendo me comunicar de casa, aí é um problema. Na escola ainda consigo melhor. (PROF.B).

Os aplicativos de áudio e voz foram inseridos na prática docente e estimulado o uso. O Hangouts foi bem aceito nas orientações de acompanhamento e planejamento das Oficinas. E o Skype serviu à apresentação oral de trabalhos discentes, com a participação presencial do corpo docente e gestor da escola, e, com a pesquisadora, a distância. Esta experiência ocorreu nos momentos em que a pesquisadora se encontrava em São Luís do Maranhão, sua cidade natal, e os alunos na Escola, o que chamou a atenção. Eles disseram:

- Que legal! Você está no Maranhão? Nossa! Parece que está aqui em Cotia! (TIAGO).

- É meio que surreal falar com uma pessoa de muito longe, mas ao mesmo tempo perto de você. (MARCOS).

A edição de documentos no Word e PowerPoint foi acompanhada de orientações da pesquisadora, tanto para as postagens dos professores, quanto dos alunos. E foi com surpresa que tanto a pesquisadora quanto os professores receberam informações novas de alunos, que conheciam os aplicativos.

O Google Drive utilizado para elaboração dos trabalhos e salvamento nas "nuvens" foi inserido na prática docente e discente. Isto justifica que existem alternativas, mesmo diante das dificuldades de infraestrutura presente nas escolas, que não possuem computadores com capacidade de memória de armazenamento. As potencialidades de uso dos aplicativos foram sendo conhecidas dos participantes no cotidiano, utilizadas e festejadas como uma grande descoberta:

- Os alunos adoraram a possibilidade de salvar as produções deles no Drive, e nós também porque aliviou nossas caixas postais. (PROF. A).

- Nossa! Eles ficaram entusiasmados com a evolução das tecnologias, compreenderam o quanto nos ajudou nas aulas. (PROF. B).

Os professores passaram a usar essa tecnologia, exercitaram habilidades para realizar o compartilhamento de arquivos em Word, PowerPoint e PDF fazer upload, download e organizar arquivos: 
- Não uso mais pendrive, meu negócio agora é nuvem! (PROF. A).

- Ah! vou salvar logo no meu Drive para não perder mais. (PROF. B).

Os professores passaram a criar e editar Docs e Slides no Google Drive e Google Forms, superando dificuldades anteriores, nunca discutidas ou solicionadas nos HTPC.

Quanto ao uso de tais aplicativos, especificamente no planejamento das atividades e organização das aulas, os Professores A e B, assim se pronunciaram:

- Descobri o Drive e já incorporei na minha rotina de planejamento. É simplesmente maravilhoso e tenho usado até para avaliar os trabalhos! (PROF B).

- Ah! Meu Drive está todo organizado. Eram muitas informações sobre o projeto Esporte. Facilitou muito também nos outros projetos. Vou usar direto! (PROF. A).

- Os trabalhos sobre Olimpíadas já organizei no Drive para serem colocados no Blog. Agora fica fácil para publicar no Blog! Estou aprendendo integrar as mídias [pausa] Beleza! (PROF. B).

Trabalhar no Drive foi um desafio para a maioria dos alunos. Mas, superadas as dificuldades, puderam utilizar melhor o horário no Laboratório com mais tempo para prática, organização e compartilhamento de arquivos; para a edição colaborativa dos trabalhos, de modo sincronizado e para o armazenamento seguro dos arquivos. Esse conhecimento beneficiou mudanças no processo de avaliação tradicional da escola; ou seja, todos compartilhavam seus trabalhos e a avaliação dos professores passou a contar com a auto avaliação dos alunos:

- Nós fizemos o trabalho no Google Drive e enviamos para os colegas e pra o professor. (DANIEL).

- Tenho um pouco de dificuldades para salvar mas sei abrir o arquivo. Eu acho importante descobrir onde errei e poder corrigir sem bronca e ajudar meus colegas. (TIAGO).

- Agora eu sei fazer a tarefa do professor, consegui corrigir vendo os comentários feitos no meu slide. Achei da ora! (ANNA).

O Blog configurou-se como o ponto de sinergia dos projetos idealizados pelos alunos e professores bem como das orientações, com pequenos tutoriais para seu desenvolvimento. Com auxílio da pesquisadora, os professores fizeram suas postagens.

Os professores inseriram vídeos, links do Google Forms e arquivos do Google Slides nas postagens elaboradas por eles. E anexaram em arquivos PDF as postagens de material selecionados na Internet.

O Blog trouxe maiores desafios, tanto para os alunos como para a avaliação dos professores. De todos os aplicativos utilizados, esse tinha por objetivo destacar as 
habilidades de comunicação e de criação, que podem ser favorecidas pelo Letramento Digital.

Trabalhar com a hipertextualidade não era algo comum na escola. A Sala de leitura oferecia oportunidades de ler livros e fazer fichamentos nos cadernos. Quando descobriram em um de seus projetos, paralelo aos das Oficinas, sobre as possibilidades de usar aplicativos de animação, como o Animoto, eles passaram a usar o Videomaker, disponível na Escola, para resumir as leituras dos livros.

Os blogs favorecem a comunicação e criação de conhecimentos dos alunos, que naturalmente querem se expressar com linguagens diversificadas e não apenas com a escrita. Apreciam postar figuras, vídeos, fazer apresentações, exercitar a habilidade de argumentar e selecionar informações pertinentes.

Os professores manifestaram dificuldades de interagir com as produções dos alunos, não em termos do domínio tecnológico, mas do que poderia ser ampliado com o Letramento Digital, quanto ao desenvolvimento de habilidades de comunicação e de saber avaliar habilidades de síntese, de avaliar o quanto tal experiência agrega às atividades escolares como práticas alternativas.

$\mathrm{Na}$ formação docente sobre a importância do Letramento Digital foram discutidas questões relacionadas ao uso responsável e apropriado da tecnologia, no acesso à Internet, aspecto evidenciado no desenvolvimento da "cidadania digital" dos alunos, conforme identificado em relatórios internacionais e documentos oficiais da legislação nacional.

As situações vivenciadas nas Oficinas, além do exercício de domínio de uso e de seleção adequada das TDIC aos projetos dos alunos, indicaram a relevância do Letramento Informacional, como desdobramento do Letramento Digital.

Professores e alunos passaram a buscar informações na Internet de forma orientada, utilizando operadores de busca e palavras-chave; selecionavam com criticidade informações relevantes, com critérios definidos; passaram a salvar e anotar as referências localizadas.

As ações docentes de mapear, narrar, tecer e mediar (MACHADO, 2008, 2015) foram sendo vivenciadas pelos professores e, naturalmente causaram impactos nas ações de aprendizagem dos alunos.

Os professores reconheceram a importância da busca e seleção de informações adequadas para atingirem melhores resultados: 
- Cê não tem noção do quanto tenho de coisa guardada [pausa] eu tô lendo um negócio, nossa! Isso aqui vou levar pra os alunos e nunca trago. Vou guardando [pausa] Acho que preciso aprender a selecionar tanto as mídias como as melhores informações para os projetos dos alunos [pausa] Eu nunca prestei atenção quando pesquiso no Google, daquelas informaçõezinhas em azul, abaixo dos links que aparecem. (PROF. A).

- Essas coisas nunca estudei na minha faculdade! Tava tudo no roteiro dos livros. (PROF. A).

- O professor deve primeiro fazer uma pesquisa com as palavras-chave sobre o assunto que vai trabalhar com os alunos. Mas, é preciso antes trabalhar o que são palavras-chave com eles, sempre [pausa] Nunca ninguém tocou nesse assunto! Os professores das outras disciplinas pedem trabalho de pesquisa e não se importam com isso. Nossa! Acho super importante! (PROF. B).

- Imagina se os alunos selecionavam informações com critérios e palavraschave [...] Vinha de tudo, nossa! Os alunos agora percebem que nem todas as informações que aparecem na busca são seguras, de fontes boas. Eles precisam saber diferenciar o que é fake e o que não é. (PROF. B).

Os alunos adquiriram confiança a partir do que aprenderam no vídeo sobre como fazer busca na Internet e incentivaram os colegas a usar esse recurso didático, publicado no Blog (APÊNDICE N):

- Muito eficaz esse vídeo, mostra como ter uma pesquisa com mais resultados parece que funciona. Vou começar a usar essas dicas! (MARTA).

- Se seguirem esse tutorial corretamente,voce fará uma ótima pesquisa,pode ter certeza! (MIZRAIM).

Aprender a fazer buscas de informações trouxe também aos alunos a possibilidade de desenvolver autonomia, porque potencializa a pesquisa e, consequentemente, a capacidade para "autoletrar-se" na Internet, conforme destacado por Xavier (2007). Neste sentido, assim se expressou uma aluna:

- Pesquisas sempre são bem-vindas, pois nelas tiramos dúvidas, aprendemos coisas bem interessantes em alguns casos, aprendemos a não depender de um adulto ou professor para nos ensinar algo. Na minha opinião é um bom começo para começarmos a ser independentes. (LIA).

Os alunos perceberam a pertinência dos novos conhecimentos para atingir objetivos específicos com a pesquisa e comentaram:

- Eu aprendi que podemos fazer pesquisas por livros mas podemos aprofundar ainda mais nossas pesquisas pela internet e assim facilitando nossa vida. (ANDRÉ).

- Muito interessante, ótimo jeito de filtrar suas pesquisas e aprender + com o conteúdo da internet que utilizamos tanto no dia dia. (JADE).

Mais da metade dos alunos respondentes (55\%) declarou que passou a selecionar uma informação com critérios para seus trabalhos (APÊNDICE O, Gráfico 5.1), o que foi um avanço considerável, já que no início da pesquisa $30 \%$ dos alunos não souberam informar sobre o que seria uma boa informação. 
Ao fazerem busca e seleção de informações na Internet, os alunos determinaram a extensão das informações necessárias (GASQUE, 2010) e expressaram atenção quanto à adequação, confiabilidade e autenticidade da informação, como disseram:

- Selecionei informações que achei necessárias para o trabalho. (ISABEL).

- Eu aprendi a pesquisar coisas através de documentos ciêntificos. (DANIEL).

- Foi meio difícil pesquisar por conta de alguns sites não estarem coerente com o tema, e também foi difícil achar imagens com o tema para cada slide. (LÍDIA).

- Antes de selecionar qualquer informação, fui atrás para saber se ela era verdadeira. (TOMÉ).

- Procuro sempre saber se o site é seguro. (JAIRO).

- Foi uma boa experiencia já tínhamos um tema depois pegamos sites confiáveis para procuramos informações e imagens e depois fizemos o power point. (MADALENA).

Os alunos indicaram cuidados relacionados à privacidade e à integridade humana, demonstrando que estavam alertas a essas questões:

- Não integrar informações físicas a qualquer site. (MARIA).

- Tenho que proteger minha privacidade. (PRISCILA).

- Tomar cuidado com as pessoas estranhas. (PAULO).

- Não baixar nada que não seja confiável. (ABRAÃO).

- Não acessarmos sites que não está no conteúdo do professor. (AGAR).

Sobre as atividades com Letramento Informacional, o que se destaca como transformação percebida foram os elementos que envolveram conhecimentos e habilidades básicas sobre o uso das tecnologias, como a capacidade para: realizar buscas de informação na Internet, orientadas por buscadores; ler e compreender hipertextos; fazer juízos de valor das informações obtidas; produzir conhecimentos confiáveis a partir das fontes selecionadas; gerenciar e organizar documentos e informações obtidas; usar a rede para interagir com outras pessoas para pedir ou dar ajuda e discutir temas; compreender um problema e procurar informações para resolvê-lo, conforme já era indicado por Glister (1997, p. 33), como habilidades presentes no Letramento Digital.

Tais habilidades apoiaram as ações de tecer significados, tanto nas orientações dos professores, quanto nas ações de pesquisa dos alunos.

A complexidade citada nos estudos sobre o tema e percebida na prática escolar confirma que o Letramento Digital implica bem mais que uma questão funcional ou instrumental, e que para transformar a informação em conhecimento é preciso que a informação seja avaliada e usada criticamente (BUCKINGHAM, 2010). 
Quanto ao Letramento Multimidiático, as ações do Ciclo contribuíram para que os professores e alunos passassem a criar e editar apresentações com slides (PowerPoint, Google Slides), fazendo uso de texto verbal e inserção de imagens com maior habilidade e a produzir hipertextos para as Oficinas a serem veiculados no Blog, demonstrando capacidade de entender informações originadas em fontes diversas e de usá-las em múltiplos formatos (WILSON et al., 2013).

Os professores buscaram ampliar suas habilidades didáticas com o programa PowerPoint, agregando conhecimento tecnológico (MISHRA; KOEHLER, 2006, 2009) ao seu repertório de conhecimentos.

- Na verdade, esse PowerPoint aí seria até bom, a gente aproveitar a Fátima pra nos ajudar. Nunca tivemos orientação sobre isto aqui na escola e nem na faculdade. (PROF. A).

- Não tenho como fazer essas coisas se você não me ajudar. Os alunos aprendem logo, logo. E gostam muito. É por conta de poderem usar textos, vídeos, figuras, animações. Nossa! É um mundo novo para eles e pra nós nem se fala! (PROF. B).

No planejamento e organização das aulas com TDIC a produção de recursos digitais foi acontecendo naturalmente e os professores $A$ e $B$ inseriram imagens e vídeos nas apresentações em PowerPoint.

- Fátima, eu preparei um powerpoint com o texto que usei na aula passada com os alunos. (PROF. A).

- Eu estou com uma ideia que acho que vc vai gostar, Fátima. Todos os alunos estão fazendo uma apresentação com slides no powerpoint. Estou pensando pegar os dois melhores grupos de cada turma e fazer uma vídeo conferência com você, para eles terem essa experiência, OK? O que acha? (PROF. B).

Verificou-se que a maioria dos alunos (75\%) fazia os slides no PowerPoint, com uso de imagens e textos; e compartilhavam com o professor, via Google Drive ou email (APÊNDICE O, Gráfico 5.1) utilizavam na produção dos trabalhos para comunicação oral do que estudaram. Seguem algumas manifestações de avaliação dos alunos:

- Foi legal porque aprendi o que não saiba do Power Point e também consegui ver meus erros de Português. (JOANA).

- O mais difícil foi fazer os slides, pois nunca tinha feito isso. Tinha medo de ser corrigido pelo professor na frente dos meus colegas. Mas, o professor foi superlegal! Me ajudou caramba! Perdi o medo. (SAUL).

- E agora quero só fazer trabalho só com slides. Não fica só na mão do professor. Todo mundo pode ver e eu estou aprendendo a fazer apresentação oral para minha classe. (REBECA). 
Foi constatado que o Letramento Multimidiático ampliou as habilidades de interpretação, criação e produção de conhecimento necessário à consolidação do processo de alfabetização dos alunos.

Essas novas formas de aprender e de ensinar se apresentaram como novas demandas na escola (LÉVY, 1998b), incentivando a cultura digital escolar.

As transformações observadas nas práticas escolares quando apoiadas por TDIC deram a certeza de que o Letramento Digital, de fato, é mais um tipo de letramento (BARTON; HAMILTON, 1998). O trabalho com a comunicação hipertextual, recomendado em estudos e documentos oficiais, é muito mais simples e fácil de ser alcançado dada a riqueza de exposição às diferentes linguagens e formatos.

O Letramento Comunicacional, destacado por Buckingham (2010), envolve a capacidade de usar a língua. E ampliar a capacidade de leitura e escrita era uma das demandas da Direção da Escola, discutidas nos HTPC com a presença da orientadora desta pesquisa, em ações de formação docente, pois muitos alunos da escola, um total de $34 \%$, identificado pelos Conselhos de Classe, estavam retidos em Língua Portuguesa. As Oficinas seriam os espaços dedicados a projetos de recuperação, que não existiam na escola. Entretanto, esta não era a compreensão dos professores participantes desta pesquisa. E como todos os alunos frequentavam obrigatoriamente as Oficinas, estabelecida como componente curricular, ficou evidente que muitos deles participaram de atividades de leitura, de escrita, de seleção de informações e de outras atividades com os aplicativos utilizados.

É interessante destacar que uma das contribuições relevantes do Letramento Digital implementada pelas ações do Ciclo, configurado no Design pedagógico desenvolvido, acabou por atender tais alunos. Tal aspecto implicou na inclusão escolar porque todos participavam colaborativamente, sem discriminação ou agrupamento por qualquer critério de seletividade.

Embora o Prof. A tenha compreendido a ação de provocação cognitiva (PICONEZ et al., 2014) como oportunidade de "diálogo entre professor e aluno, para que eles ampliem seus conhecimentos", nos grupos focais os professores avaliaram seus maiores desafios:

- Tem um passo ainda a ser dado dentro do Blog, faltou maior interação com eles. Dominar o uso do Blog já dominam; agora, é preciso provocar mais [pausa] Eu pensei na provocação, na hora que tava pensando: tenho que fazer uma provocação pra os meninos! (PROF. A). 
- É difícil fazer avaliação no Blog [pausa] E isso é complicado, porque aqui na sala de aula, eu tô vendo o que tá acontecendo e eu vou lá na hora [pausa] Pra isso funcionar legalzinho, quando eles tivessem conectados aqui eu tinha que tá conectada junto com eles, porque aí eu ia ver o que eles estavam produzindo e, na mesma hora, poderia falar com eles aqui mesmo. Fazer na sala eu até consigo, mas no computador, não consigo. $O$ que eu tenho que provocar? Não é mais se sabem usar o blog ou não [pausa] Acho que tenho que avaliar se eles estão escrevendo melhor! (PROF. A).

- Outro dia uma aluna chegou pra mim e disse: "professora eu entrei lá no Blog e não tem dever de casa!" Mas eu não dou dever de casa, eu disse. Ela quis dizer: "eu entrei lá e não tinha nada novo! E aí, o que eu vou fazer de novo essa semana em Orientação de Estudos? Não tem dever de casa essa semana?", ela falou. Eu não coloquei nada naquela semana, eu disse pra ela: pode deixar eu vou colocar lá, o dever de casa [risos] (PROF. A).

Alguns alunos criaram blogs sobre temas variados e comentaram nos blogs de seus colegas.

Houve mudança no texto dos alunos publicados no Blog, pois:

- No começo, quando a gente abriu lá o Blog, alguns começaram a escrever de qualquer jeito, até xingaram lá, lembra? Mas depois que a gente trabalhou com eles, que tem que fazer no capricho, tem que chegar lá, escrever, escrever, ler antes de publicar [pausa] Hoje eles entram lá pra fazer um trabalho com aquela preocupação, ele têm o maior cuidado. Agora sabem que colocou na Internet, compartilhou mesmo! Todos podem ver! (PROF. B).

Os alunos passaram a dar atenção à correção gramatical do texto e às regras de comportamento nas redes, elemento fundamental do Letramento Comunicacional. Destacaram cuidados relacionados ao respeito às pessoas e com a informação de suas postagens, com atenção para o uso ético e legal das informações (ATHENIENSE (2013; GASQUE, 2010).

Os alunos se posicionavam sobre suas postagens como avaliadores também de suas produções e aprenderam a usar a informação de forma ética ATHENIENSE (2013; GASQUE, 2010), com comportamento prático e responsável, como:

- Não devo postar coisas que não são minhas. (NOÉ).

- É bom ver as coisas que postamos se tem de ser postada. (PAULO).

- Verificar o que eu publico antes. (MARCOS).

- Não provocar nem ameaçar ninguém. (MARIA).

As regras de comportamento e de escrita são identificadas em todos os comentários dos alunos. Eles expressaram alguma satisfação com as postagens. Nos comentários foram usadas expressões de elogio, envolvendo os termos: "legal", "muito bom", "gostei”, "gostei muito", “amei”, "adorei”, "interessante", "importante"; "maravilha", "maneiro" ou "bacana", em relação à atividade proposta pelos professores, à TDIC anexada na postagem, ou ao conteúdo comunicado. 
Houve respostas curtas com uso dessas expressões, comentários com elogios seguidos de posicionamentos acerca da postagem, comentários que indicaram o que havia sido aprendido e sobre a utilidade do conteúdo em suas práticas de estudo e pesquisas futuras.

O uso orientado das TDIC provocou nos professores e alunos o enfrentamento do medo, da insegurança nas apresentações de trabalhos, que se estenderam da sala de aula, ao coletivo de professores e ao corpo gestor, chegando à oportunidade de um grupo de alunos representar a Escola Fernando Nobre em eventos científicos e em eventos organizados pela SE/SP na Regional de Carapicuíba e na própria Escola.

A experiência com o planejamento e organização nos trabalhos com TDIC para muitos alunos foi um desafio que foi sendo superado pelas orientações dos professores, com apoio da pesquisadora e colaboração de colegas:

- Foi um pouco complicado planejar, organizar o trabalho mas com outras pessoas do grupo, foi legal produzir o trabalho. (ISABEL).

- Minha experiência foi boa, muito organizada, pois começamos a fazer o trabalho em etapas e isso nos ajudou. (SAUL).

- Primeiramente fizemos uma pesquisa sobre o uso do celular para sabermos quais são os perigos, depois conversamos sobre isso, para montar um trabalho. (LÍDIA).

- Sei planejar colocando na ordem e organizo conforme o planejado. (TIAGO).

O formato da comunicação oral do trabalho, via Skype, fascinou e envolveu os alunos pela novidade:

- Minha experiência foi boa, falar com uma pessoa de outro lugar explicando o trabalho. (ISABEL).

- Foi interessante e ao mesmo tempo inusitada pois era uma coisa nova e diferente, com certeza tive menos vergonha. (SAUL).

- Para mim a experiência foi difícil por que eu nunca tinha usado o aplicativo. (ABRAÃO).

- Não sabia mexer no Skype. (PEDRO).

Essa experiência da apresentação via Skype, como atividade para avaliação das Oficinas, foi estimulante ao desenvolvimento dos alunos, inclusive no aspecto emocional, como eles revelaram:

- Foi uma das melhores experiências escolares que já experimentei só me senti nervoso por ter que apresentar um trabalho ao vivo pela minha primeira vez, mas bom até para eu poder me preparar para futuras apresentações. (JOSÉ).

- Bom fiquei um pouco nervosa, mais fiquei muito feliz de falar com uma pessoa com uma linguagem e lugar diferente. (CLAUDIA).

- Pra mim é meio que tenso porque tenho medo de errar alguma coisa na hora de apresentar. (LÍDIA). 
A colaboração entre os colegas é algo que requer atenção e precisa ser sempre estimulada, tanto em atividades em classe como em atividades na nuvem. Além de ser de grande importância, pelas habilidades de argumentação e persuasão necessárias ao Letramento Comunicacional, é valorizada pelos alunos, pois alguns enfrentam dificuldades:

- Eu não fis quase nada porque meus colegas não me deixaram opinar. (MARCOS).

- Cada um deu a sua opinião foi bem legal. (PRISCILA).

- Eu fui aprendendo com os meus colegas. (HULDA).

Com a interpretação das informações veiculadas na Internet sobre o tema estudado "uso inadequado de celulares", os alunos afirmaram ter mudado de hábito após o trabalho, revelando o que aprenderam sobre o uso moderado do aparelho:

- O celular é necessário mas pode trazer riscos graves. (ISABEL).

- Devemos mexer pouco, porque pode causar problemas sérios. Esse trabalho me ajudou como pode ter ajudado outras pessoas para refletir um pouco mais sobre os danos do celular. (LíDIA).

Fazendo uso social da leitura realizada (SOARES, 2014), os alunos aprenderam a ter maior cuidado com a saúde e com os outros, como por exemplo:

- Eu aprendi uma coisa nesse trabalho, que os materiais usados podem causar problemas na natureza, quando eu crescer, posso passar isso para os meus filhos e passar de geração a geração. (CLÁUDIA).

- Não ficar muito no celular por que pode causar problema de coluna. (ARÃO).

- Não usar celular curvado. (PEDRO).

- Não jogar o celular inadequadamente no lixo. (PRISCILA).

A atratividade e funcionalidade do Blog foi destacada por alguns alunos

- Eu achei o site muito elegante, eu aprendi muita coisa legal! (ESTER).

- Curtam esse blog. (ELIAS).

- Muito legal! Assim posso saber sobre o que perdi ao faltar! (ANA).

- Aqui no blog temos os conteúdos em páginas pra a pessoa não ficar perdida (SIMÃO).

- O blog pesquisa nobre foi criado pra aprimoramento da oficina orientação de estudos. (JOÃO).

Um dos alunos deixa o convite para conhecerem o seu Blog: "adorei o post, passa no meu blog." (LUCAS).

Tais aspectos também foram de extrema valia para o professor-observador desta pesquisa-ação, que atuava na Sala de Leitura. As vivências observadas estimularam sua ação sobre o desenvolvimento da leitura e escrita, na qual a escola aceitou o convite do Instituto Ayrton Senna para ganhar uma sala de leitura equipada 
com notebook, Wi-Fi, livros e estantes. Os alunos produziram vídeos com os conteúdos da leitura de autores clássicos dos livros doados e a Escola foi premiada, informou o Prof. da Sala de Leitura.

\subsection{DESAFIOS NO USO DAS TDIC NO CONTEXTO ESCOLAR}

Mesmo motivados para uso das TDIC, os professores sentiam-se inseguros, redundando na prevalência das tecnologias não-digitais, já dominadas por eles. Tudo isso evidenciou a falta de formação adequada, como testificaram:

- Falta uma cultura de usar os aparelhos para fins pedagógicos. (PROF. B).

- É nova essa forma de construir conhecimento e de elaboração de materiais didáticos. (PROF. A).

- Há pouca formação dos professores sobre o uso pedagógico das tecnologias. (PROF. A).

A percepção dos professores acerca das novas formas de ensinar era de ser algo complicado e difícil. A sensação do desconhecido carregou a ideia de algo trabalhoso, com demanda de tempo para dedicação, o que gerava conflito entre a vontade de usar tecnologias e o receio em usá-las:

- Vai fazer como? Digitado, ou a mão? (PROF. B).

- A mão, né? Digitado vai dar um trabalho danado! (PROF. A).

- "Professora, você está vendo o que eu escrevi lá?" Eu disse: tô sim! Mentira [risos]. Ele disse: "Então você tá vendo tudo?" Ah! [risos], se você viu Fátima, são meus olhos [risos]. (PROF. A).

Além dessa percepção, um fato foi emblemático - a preocupação com possíveis exigências da SE/SP e com regras da Escola Fernando Nobre para uso do Laboratório.

- Acho viável apresentar tecnologia na Feira Cultural, mas será que a escola vai permitir usar os computadores? Tem que conversar com a Coordenadora. Cê acha que a gente consegue deixar a Sala de Informática aberta nesse dia? (PROF. A).

- Mesmo que nós tivéssemos estrutura pra isso, nós não poderíamos, porque a gente poderia até trabalhar essa parte toda virtual, essa coisa toda, só que eles [SE/SP] iam acabar cobrando da gente, iam dizer: E aí, o que o menino escreveu? [pausa] Ah! Tá lá no Blog! No Blog? Mas escrever no computador? Não está trabalhando a letra? Não tão trabalhando isso, não tá trabalhando aquilo? [pausa] É complicado! (PROF. A).

- Isso é cobrado da gente [pausa] O caderno! O sistema todo cobra isso. Mas, e aí, como que eu vou apresentar isso [Blog] na Feira? Essa que é a questão! Tem que ter alguma coisa física. Estava pensando em fazer no papel mesmo e pendurar lá [pausa] A gente precisa ter alguma coisa escrita pra supervisora! (PROF. A).

- Pode ser um cartaz, algo escrito com habilidades trabalhadas. (PROF. B). 
A preferência dos professores por manter a apresentação de trabalhos manuscritos se manteve, mesmo com a inserção das TDIC:

- Prefiro um trabalho na mão do que um voando na Internet. (PROF. A).

- Primeiro vão fazer no caderno, porque eu prefiro à mão, do que impresso, dá impressão de autenticidade! (PROF. B).

- Podemos colocar os trabalhos no varal, pendurados. Podemos mostrar pra os pais deles. (PROF. B).

- Vamos fazer tipo cortina, faz dois buraquinhos e passar o barbante, assim, tipo álbum seriado. Vamos colocar todos os varais no refeitório! (PROF. A).

Os professores se animaram para fazer vídeos no aplicativo Animoto:

- Podemos fazer vídeos, ia ficar muito legal. Vamos começar pela seleção de fotos. (PROF. A).

A mediação das TDIC, assim como a tarefa de provocar e incentivar a resolução de problemas na produção dos vídeos deram origem à produção de um tutorial pela pesquisadora (APÊNDICE N). Foi constatada a interdependência de conhecimentos tecnológicos (computacionais, multimidiáticos) e pedagógicos, perceptível pela necessidade de sua integração nessa atividade:

- Não consegui baixar o Animoto no celular. Como posso fazer para ajudar meus alunos? O tutorial que vc fez foi muito bom para eu entender que preciso conhecer e usar as tecnologias antes de exigir dos meus alunos que saibam fazer. (PROF. B).

- Não consigo fazer o vídeo, nem no celular, nem em no computador. Ter acesso às tecnologias não significa que sei fazer ou que meus alunos aprenderam aquilo que tinha como objetivos [pausa] Precisamos sempre estudar, usar para depois saber avaliar o que nossos alunos fazem. (PROF. A).

A disponibilidade de tempo dos professores, resultado das condições de trabalho na carreira docente, foi um fator limitante, muitas vezes expresso durante as ações realizadas. A falta de tempo dos professores também incidiu na qualidade da interação online com os alunos, porque foi percebido no Blog um movimento diferente da comunicação professor e aluno, mas ainda tímido. Inicialmente, os professores tiveram limitações, que foram identificadas também por Velloso (2010), que observou participação unilateral no blog em sua pesquisa.

Uma das contribuições da Ação foi o impacto quanto ao uso do Laboratório, que passou a ser usado com frequência, mesmo com as dificuldades já descritas. $O$ agendamento dos horários passou a ser uma rotina na Escola, porém com marcação de forma livre, afixada na Sala de Professores para que pudesse ser usado pelos professores das demais disciplinas. Os alunos faziam fila nos intervalos para se cadastrarem para usar o espaço. 
No acompanhamento às turmas no Laboratório, frequentemente era observado algumas dificuldades para o acesso ao Blog, o que foi confirmado por $42 \%$ dos alunos respondentes: esquecimento do login ou da senha do Google; esquecimento do Registro do Aluno ${ }^{63}$ (RA) para usar o computador (APÊNDICE O, no Gráfico 5.2).

As redes sociais complementares como o WhatsApp, Facebook, Skype e, com os alunos, o Blog, reforçaram o valor das mídias. Os alunos passaram a usar os próprios celulares (BYOD) no desejo de produzirem seus projetos. E os professores perceberam a importância do diálogo online com a pesquisadora e com seus alunos confirmando a urgência de novos modos de interação professor/aluno, aluno/aluno. Observou-se um protagonismo com autonomia para afinal, driblar um problema de infraestrutura da escola.

\subsection{A ÓTICA DOS PARTICIPANTES SOBRE AS AÇÕES DE LETRAMENTO DIGITAL}

As contribuições das referências do Letramento Digital retomadas na Ação implementada, manifestas pela ótica dos participantes foram consideradas importantes tanto pelos alunos como pelos professores. Quando indagados sobre as ações, detectavam as dificuldades, mas com sua superação.

O Prof. A considerou excelente a trajetória com as TDIC, porém enfatizou que:

- É preciso melhorar mais na condução da mensagem que estamos querendo passar aos alunos. Avançamos esse ano, pois conseguimos, com as tecnologias, dialogar e ouvir mais os alunos, suas mensagens. Agora temos que melhorar a interação.

Em relação à prática, o Blog e as outras mídias usadas, os professores avaliaram que:

- Facilitou a organização das matérias aplicadas em aula e a comunicação dos professores com os alunos e mesmo entre eles. (PROF. A).

- Estou muito feliz por ter conseguido que os alunos acessassem o Blog e com o envolvimento da turma no caça-palavras, preparando-se para construir o glossário no Blog. Isto é muito importante porque os alunos passaram a ler muito mais, a selecionar informações para as pesquisas e postagens no Blog. Procuravam as palavras no celular e integravam com a escrita nos cadernos deles. (PROF. A).

- Aprender a usar a tecnologia como uma ferramenta onde podemos expor nossas ideias, trocar informações e experiências e construir conhecimentos. Essa experiência da pesquisa agregou valor, me enriqueceu muito. (PROF. A).

\footnotetext{
${ }^{63}$ Em 2016 para acesso ao sistema da Escola, a senha era os quatro últimos números do RA.
} 
- Aprender é mais do que memorizar [pausa] Na verdade, estou aprendendo muito [pausa] $O$ fato é que já perdemos muito tempo. Há muitos e muitos recursos disponíveis! Precisamos todos saber como aplicar em nossas aulas. (PROF B).

As TDIC utilizadas junto aos alunos: vídeos, PowerPoint, Drive Google (Docs, Forms e Slides) e o Blog foram avaliados pelos professores, que além do uso com intencionalidade educativa para desenvolver habilidades de Letramento, extrapolaram para considerações além do seu uso:

- As TDIC podem ajudar na pesquisa deles [alunos] e os resultados podem publicar no Blog. Isto é economia de papel! Mas precisamos de mais tempo, que às vezes não temos aqui na escola. (PROF. B).

Os professores e observadores da pesquisa foram unânimes em indicar a continuidade do Blog.

- A gente gostaria de continuar com essa experiência com tecnologias ano que vem, mesmo mudando de oficina, porque muda todo ano; mudam os professores também. Na verdade, os alunos continuam os mesmos e esta aprendizagem vão levar para a vida toda! (PROF. B).

- O Blog foi um sucesso, tivemos 102 alunos como seguidores. Agora temos que manter! (PROF. A).

- Os alunos visualizaram as páginas, fizeram comentários, deram respostas às enquetes. A participação dos alunos foi muito boa. Ampliou a capacidade de auxiliar em suas escolhas e inserção a novos modos de acesso à informação e de produção de conhecimentos. (PROFA. JOSETE ZIMMER).

- Quem não era seguidor entrava com o login do colega. Achei o máximo! Eles começaram a resolver problemas. (PROF. A).

- Antes de conhecermos a possibilidade de comunicar conteúdos e provocar as tarefas dos alunos em um blog e as outras mídias que se pode usar para ensinar e avaliar, os alunos ficavam meio soltos no Laboratório porque não se sabia o que fazer. Agora o blog é acessado pela maioria da escola! (PROF. B).

- Agora ficou fácil fazer pesquisas de campo com os formulários do Google, é só postar no Blog e acompanhar as respostas com os gráficos que são criados. (COORDENAÇÃO PEDAGÓGICA).

Os alunos também avaliaram a Oficina (APÊNDICE O, Gráfico 5.3), 29\% deles responderam que não mudariam nada nessa Oficina; e $22 \%$ dos alunos sugeriram itens relacionados à infraestrutura tecnológica e ao trabalho pedagógico na Escola, tais como: mais computadores e mais acesso à Internet; $6 \%$ sugeriram integração e suporte para outras disciplinas; $6 \%$ mais aulas no Laboratório; e $37 \%$ dos alunos não responderam esse item ou não sabiam informar.

Especificamente em relação aos trabalhos com TDIC, os alunos passaram a fazer trabalhos em outras disciplinas usando mais as TDIC. Seu uso conferiu sentido e significado, sendo registrados comentários valorativos, como:

- Esse trabalho foi o melhor que eu fiz na minha vida. Quero fazer todos meus trabalhos da mesma forma! (TIAGO). 
- Estamos gostando muito de fazer esse trabalho! Agora entendi o que existe na Internet! Gente! Tem muita coisa legal para me ajudar a estudar as matérias. Não fico mais só no blá blá blá com meus amigos. (LOIDE).

- Que bacana esse trabalho! Agora sei usar a internet correto, precisa sair dos joguinhos. A internet tem muita informação muito boa para nós. É só saber procurar. (MICAL).

Quanto às vantagens no uso de TDIC para os alunos, os professores consideraram que foi favorável, tanto ao maior interesse às aulas, como para o desenvolvimento dos alunos.

O Prof. A destacou as contribuições das TDIC, vivenciadas com o Design pedagógico, para as ações de busca de informação adequada, na possibilidade de arquivamento, compartilhamento e divulgação de documentos e do que podem produzir junto aos alunos:

- As tecnologias fazem parte do dia a dia de nossos alunos, por esse motivo acaba trazendo para as aulas uma interação maior com o conteúdo que está sendo abordado; desenvolvimento da leitura e da escrita; envolvimento dos alunos e a atratividade; traz rapidez de feedback. Eu tenho aprendido muito com minhas reflexões e com meus alunos!

Quanto às contribuições da pesquisa, os observadores reportaram-se ao uso da tecnologia em si, às atividades realizadas e ao conteúdo das Oficinas. E destacaram que todos aprenderam, alunos e professores, estes últimos, após identificarem suas limitações com as TDIC, o que reafirma que "identificar os limites do conhecimento que se tem no momento, e então tomar providências para remediar a situação, é muito importante para aprendizes de todas as idades" (BRANSFORD; BROWN; COCKING, 2007, p. 74).

- A criação do blog para estudo nessa Oficina revitalizou as relações interativas e até socioemocionais dos alunos. A cooperação passou a fazer parte da rotina dos alunos, estimulada pelo uso das tecnologias, com o Ciclo. Os alunos conseguiram fazer pequenos planejamentos de seus trabalhos e tarefas. A disciplina melhorou e até casos de bullying. (PROFA. JOSETE ZIMMER).

- A oportunidade de maior interação na escola com os blogs favoreceu a proposta inovadora. Os professores estão ansiosos para rever o modo deles planejarem as aulas. Isso é muito bom de vivenciar na escola, apesar de seus problemas. (COORDENADORA PEDAGÓGICA).

- A presença constante da pesquisadora na escola, em contato com os professores e alunos lançou um embrião que levou os professores para melhores reflexões, porque eles estavam se sentiam pressionados para cumprir todo o conteúdo do currículo e se limitavam à aula expositiva, sem trabalhar projetos nem com tecnologias digitais. (COORDENADORA PEDAGÓGICA).

- A professora [Prof. A] admitiu que tem muito a aprender; assumiu que passou a usar as tecnologias digitais de informação e comunicação com finalidade educativa. Na verdade, o Letramento sugere um currículo em permanente construção. Todos precisam participar e estabelecer uma rede de significados para suas ações de educar. (PROFA. JOSETE ZIMMER). 
- A grande contribuição foi a diferença no interesse dos alunos naquilo que a gente estava dando [pausa] É visível o interesse deles! Olha! Eu fui monitora pelo Mais Educação, um ano nessa Oficina, depois peguei quase todas as turmas ano passado [2015] e esse ano eu tô com essas turmas e é visível o interesse deles, a diferença de interesse deles esse ano, com o que a gente tá dando, com o Blog! (PROF. A).

- A contribuição primordial aí foi o Blog, né? O blog nos ajudou de uma forma tremenda, pelo fato das crianças até então iam pra Internet, pensando em [pausa] Se a gente vacilasse, eles ficavam só vendo Facebook, WhatsApp, abrindo aí qualquer uma rede social. Então, você chega lá, com essa proposta, eles gostaram da ideia, gostaram de entrar, acho que ficou mais fácil, foi legal, toda essa interação. Você percebe que a contribuição foi total, total, no sentido de poder desfocar um pouco deles achar que o computador era só pra fazer aquilo! (PROF. B).

E em relação às expectativas educacionais e profissionais docentes e discentes, a pesquisa agregou um componente motivacional, como o Prof. B enfatizou:

- Foi muito enriquecedor trabalhar com você, obrigado por todo apoio. Nos trouxe a oportunidade de mostrar aos nossos alunos o caminho da pesquisa e a chance de sonhar com uma universidade pública, acima de tudo a facilidade de trabalho com as mídias. Trouxe a oportunidade de trabalhar com pessoas que estão em patamar acima de nós e que nos permite trocar experiências com pesquisadores. Com isso, os nossos alunos percebem que o sonho da pesquisa ou até mesmo de uma universidade tão renomada não está tão longe dá realidade deles. (PROF. B).

O Prof. B afirmou que a pesquisa contribuiu com sua formação, que foi muito fortalecido, e que até já conseguia desenvolver as ações do Ciclo, com maior facilidade. Dos recursos digitais trabalhados na pesquisa ele afirmou que viu e estudou todos e que os conteúdos foram úteis na sua prática docente, procurando fazer uso de todos, inclusive em outra escola onde atua.

O sentido do Ciclo para os professores se deu em três direções: a posição dos alunos no Ciclo, a importância e o movimento do Ciclo, como exemplificado nos excertos abaixo.

- Os alunos estão no centro desse ciclo. Sei agora mapear relevâncias, antes eu não sabia! Nem eles! (PROF. B).

- As ações nesse ciclo vão acontecendo concomitantemente. Estou aqui com muitas ideias para minhas próximas aulas! Vou percorrer por ele com as tecnologias! (PROF. A).

Avaliando a atividade da Mostra de TDIC na Feira 2016, os observadores declararam no Facebook da Escola:

- Parabéns aos alunos por brilhante apresentação e para os professores orientadores [...] Especialmente, parabéns para professora Fátima Rios, idealizadora do blog e para a professora Josete Zimmer, apoiadora nas tecnologias digitais de informação e comunicação. (COORDENADORA PEDAGÓGICA).

- Parabéns alunos! Estou feliz que vocês estão aprendendo e interagindo com as professoras [...] e Fátima por meio deste blog. Eu também assisti o vídeo e gostei da explicação fácil para dar crédito aos autores, tanto nos livros como na Internet. (PROFA. JOSETE ZIMMER). 
- Aquele trabalho sobre o uso do celular irá representar a Escola na Feira de Ciências na diretoria de ensino, acredito que em novembro [2017] São os alunos que irão apresentar. Essa feira é uma seleção dos melhores para apresentar o Estado em alguma feira. (PROF. B).

O trabalho dos alunos com TDIC sobre os riscos do uso inadequado do celular foi apresentado em PowerPoint por todos os grupos de alunos nas aulas das Oficinas Orientação de Estudos e Oficina Qualidade de Vida. O Prof. B selecionou alguns grupos para apresentarem oralmente o trabalho ao corpo gestor e docente da Escola e aos pesquisadores do Grupo Alph@ e na oportunidade foi utilizado o Skype. Em decorrência desse trabalho, a pesquisadora incentivou o Prof. B a expor o relato ${ }^{64}$ dessa prática em evento científico na área. Então, o relato foi elaborado de forma colaborativa (ver RIOS et al., 2017) e a consequente apresentação foi dada por um grupo de quatro alunos, acompanhados pelo Prof. B, no VI Web Currículo e em outros eventos na Região Metropolitana de São Paulo. Teve ampla repercussão ${ }^{65}$ e registro em uma matéria no site da SE/SP, com a manchete "Alunos aprendem a usar celular de forma consciente", na seção "A Escola Que Queremos”, destacando um dos resultados do trabalho:

O trabalho foi apresentado na PUC (Pontifícia Universidade Católica), durante o Web Currículo, um encontro anual onde pessoas de todo o mundo apresentam suas experiências em sala de aula. Os alunos e o orientador participaram para contar a experiência, falar como foi feito o trabalho e o que mudou na vida deles. O trabalho foi exposto na Feira de Ciências da DE Carapicuíba e, por fim, os alunos fizeram uma apresentação para o Secretário José Renato Nalini, durante um ato solene que marcou a reforma da unidade e de mais oito escolas da região. (SÃO PAULO, 2017b).

Tendo em vista a cultura digital escolar, os professores e observadores contribuíram com algumas sugestões:

- O HTPC podia ser pra o acompanhamento virtual dos alunos, pra eu olhar o que eles estão escrevendo lá. Não tem esse tempo. (PROF. B).

- Essencial era se eu tivesse um computador na sala e programas pra eu acompanhar eles em tempo real nas atividades. Preciso aprender a lidar com a pesquisa pelos celulares em sala de aula! (PROF. A).

- Devia ter acesso às redes com maior amplitude da Internet banda larga, pois esse é um dos maiores problemas na Fernando Nobre. Só que agora, como isto não é fácil de se resolver vou usar mais o que posso acessar com meus alunos pela Web. (PROF. SALA DE LEITURA).

A habilidade para usar os equipamentos digitais favoreceu a possibilidade de reinvenção do cotidiano das Oficinas de Orientação de Estudos, bem como

${ }^{64} \mathrm{O}$ resumo do trabalho está publicado nos Anais do V Web Currículo. Disponível em:

<http://www.pucsp.br/webcurriculo/anais.html>.

65 Disponível em: http://www.educacao.sp.gov.br/noticia/boaspraticas/alunos-aprendem-a-usar-celular-de-formaconsciente/. 
estabeleceu novas formas de agir, que se revelaram em práticas alternativas e em modos diferentes de utilização das TDIC. Os participantes desta investigação foram unânimes em afirmar que o tema Letramento Digital deve ser incluído em todas as ações de formação dos agentes das escolas, preferencialmente no próprio local de trabalho. 


\section{CONSIDERAÇÕES FINAIS}

As contribuições do Letramento Digital como referencial norteador puderam ser observadas no contexto escolar e revelaram mudanças significativas ao processo de ensino-aprendizagem.

A criação e implementação do Design pedagógico configurou-se como um espaço de formação de professores e, uma vez conhecida a realidade escolar, a pesquisadora assumiu o papel de tecelã de significações dos complexos aspectos que precisam ser conhecidos e considerados para que ocorra desenvolvimento do Letramento Digital. Assim, o Design pedagógico foi decorrente da tessitura elaborada de forma conjunta com os participantes da pesquisa para desenvolvimento de competências digitais de professores e alunos.

A intencionalidade educativa conferida ao mapeamento de informações, definição das TDIC para planejamento, organização, construção colaborativa, comunicação dos conteúdos e produções da pesquisadora, dos professores e dos alunos, trouxe contribuições significativas ao processo de ensino-aprendizagem.

A tese representa um convite à reflexão sobre as questões do uso das TDIC e enfatiza a necessidade de se considerar a complexidade de diferentes dimensões no qual está envolvido o contexto escolar.

A revisão de estudos indica que a produção acadêmica sobre o tema tem se ampliado e recomenda continuidade. Os estudos apontaram a necessidade de integração de diferentes domínios de conhecimento, incluindo os conhecimentos tecnológicos e pedagógicos para o uso de TDIC (TPACK).

A leitura cuidadosa dessa produção permitiu identificar a preocupação com a formação do professor para atuar com as tecnologias digitais como suporte didático; demonstrou que os trabalhos focalizam a tecnologia com suas funções e recursos para o processo de ensino-aprendizagem. No entanto, especificamente na área da Educação, no Ensino Fundamental, ainda carece de maior aprofundamento, pois a presença de TDIC na escola não assegura a necessária formação docente e infraestrutura adequada, tampouco aprendizagens significativas. Com os estudos sobre Letramento Digital ficou claro que a escola tem uma função social importante em considerar o contexto dos alunos, no atendimento às diferenças e à diversidade cultural. 
Os alunos desta era usam as tecnologias digitais em seu contexto social, os professores também. Portanto, ignorar esse fato pode ser prejudicial à sociedade. As TDIC avançam e se modificam exponencialmente; e ao mesmo tempo, informações podem ser acessadas ubiquamente, com integração de dados e conhecimentos que, por sua vez, podem ser compartilhados em redes sociais. Os livros didáticos podem estar articulados às possibilidades online sob perspectiva de atualização complementar permanente.

Os estudos com foco no contexto escolar discutem a articulação da teoria e prática no trabalho pedagógico com as TDIC, porém, com tratamento isolado das demais disciplinas curriculares. O acesso à Web favorece a construção de conhecimentos de forma intra e interdisciplinar, postura metodológica para qual os professores se sentem desafiados. Os estudos finalizam com recomendações sobre a relevância da formação docente (inicial e continuada), mas existe uma lacuna com o desenvolvimento de uma práxis, também requerida na apropriação das TDIC. Os documentos e relatórios oficiais sobre capacitação docente determinam objetivos, padrões de competência e desenvolvimento de habilidades, entretanto tais documentos são pouco conhecidos pelos agentes escolares.

A força da tradição educacional, que ainda centraliza decisões na figura do professor, posicionado como "transmissor", compromete a ação dos alunos como protagonistas na construção de conhecimentos. E as TDIC, muitas vezes, são tratadas com reserva. Estudos apontam mudanças no perfil do professor não mais como único fornecedor de conhecimento, mas como pesquisador e articulador de saberes, dentre outros. Os alunos passam pela transição da passividade ao protagonismo, estimulados pelo desenvolvimento de habilidades por meio de atividades e recursos mais dinâmicos e colaborativos.

Nas produções inseridas na Grande Área de Linguística, Letras e Artes, em maior número, foram identificadas discussões sobre a hipertextualidade presente e acessada na Web. A maior incidência das produções recai sobre os gêneros textuais; pesquisam sobre atividades escolares de leitura e de escrita; ampliam conceitos de letramento; identificam que o acesso à Web proporciona diversidade de abordagens dos conteúdos, já que podem ultrapassar os limites físicos da escola. Muitos estudos referem-se ao trabalho de autoria em mídias específicas, que estimulam os alunos para diferentes leituras e modos de construir conhecimentos. 
Nos estudos inseridos na Grande área de Educação, especificamente no Ensino Fundamental II, as poucas produções focalizam mais o uso de aplicativos e, em menor frequência, as competências docentes para usar as TDIC, com referência dada pelos estudos sobre Letramento. Com as produções acadêmicas e a situação revelada em relatórios nacionais e internacionais, mesmo o Letramento Digital sendo concebido como uma demanda social e um direito, permanece o grande desafio no âmbito governamental e nas instituições de ensino para a superação das dificuldades e sua implementação no contexto escolar.

A partir da revisão de estudos bibliográfico e documental, esta pesquisa procurou investigar ações para provocar e compreender as contribuições do Letramento Digital e sua inserção na organização curricular; a questão da formação de professores e da infraestrutura tecnológica necessária, a fim de apoiar o desenvolvimento de uma cultura digital na escola em questão.

As práticas escolares no contexto pesquisado mesmo tendo a presença de TDIC (laboratório com computadores, Wi-Fi, blogs etc.) não possibilitava uma visão de hipertextualidade que fornecesse alternativas para os alunos aprenderem a fazer suas pesquisas na Web.

Postas estas considerações, que sintetizam o contexto no qual a investigação esteve inserida, são compartilhadas a seguir, outras reflexões da trajetória de construção da pesquisa e seus resultados.

Um dos resultados alcançados foi a constatação de que a conectividade com as TDIC cria suporte com o qual professores e alunos podem apreender maior sentido e significado aos conteúdos (conceituais, procedimentais e atitudinais) recomendados pela legislação educacional e presentes no Plano Escolar.

Compreendeu-se que as contribuições da prática com a hipertextualidade para professores e alunos decorrem de um planejamento. Por isso, a efetividade da implementação de ações com TDIC estabeleceu-se como um desafio complexo e dependente de um design pedagógico que, por sua vez, requereu desenvolvimento das competências docentes ligadas ao mapear relevâncias, construir narrativas, tecer significados e mediar relações capazes de fortalecer atividades de ensino, de estudo e de avaliações dos alunos.

O Letramento Digital apresentou-se como referencial que alicerçou os conceitos envolvidos na criação e implementação do Design pedagógico. A intencionalidade educativa atribuída à seleção, uso e avaliação das TDIC disponíveis no contexto 
estudado, indicou direção promissora para o alcance das habilidades determinadas previstas na legislação educacional brasileira.

O Letramento Digital, concebido como um continuum no Design pedagógico, permitiu realizar e integrar as ações de acessar, localizar, selecionar, mapear informações, planejar, organizar, construir narrativas, usar a informação, construir, avaliar e compartilhar conhecimento nas práticas de ensino e aprendizagem, com a possibilidade de protagonismo na resolução de problemas.

Uma das contribuições relacionou-se com o Letramento Informacional, sendo possível propor e realizar atividades educativas no âmbito escolar, a fim de desenvolver o pensamento crítico e reflexivo sobre o uso das TDIC, indispensável para a ação responsável dos cidadãos. Ou seja, além de proporcionar o conhecimento e domínio de uso das TDIC, o Design pedagógico ofereceu oportunidades de discussões sobre problemas de contextos sociais e da comunidade onde vivem.

Contudo, foram vários os fatores influentes para que o Letramento Digital não fosse colocado plenamente em prática no contexto escolar pesquisado, dentre os quais se destacam: a infraestrutura e a formação docente inadequadas; e a prevalência de uma concepção tradicional do processo de ensino-aprendizagem e da organização curricular, expressa na pesquisa nas dimensões administrativa e didática-pedagógica. Além disso, a Escola Fernando Nobre passou por vários percalços, como a alta rotatividade docente e as mudanças curriculares anuais; uma política de recursos humanos com pouco incentivo à classe docente e à continuidade de trabalho na mesma instituição; e, em grau menor, ruídos na comunicação interna, que comprometem a interação e a efetivação dos processos na escola.

Muitas discussões permitiram compreender que as mudanças na perspectiva de um novo modo de planejar e ensinar se dariam a partir da atribuição de sentido e significado ao uso das TDIC por parte dos professores, tendo como intuito o Letramento Digital na escola e para que este se tornasse objeto de reflexão e transformação nas práticas educativas.

O hábito da reflexão consistiu em um dos aspectos mais relevantes no processo da formação dos professores com esta pesquisa e, nas discussões sobre o Design pedagógico, oportunizou o olhar crítico sobre a prática da improvisação, tão presente nos planos e projetos didáticos nas escolas. 
O Design pedagógico contextualizado foi importante para as mudanças nos modos de planejar, ensinar e de aprender sob a perspectiva de um processo dialógico, coerente com valores voltados para uma educação democrática.

O Ciclo de Ações Educativas apoiadas por TDIC teve fundamentação nas ações docentes (mapear, narrar, tecer e mediar) e alicerçou a pesquisadora na tarefa de tecer significações para a trajetória empreendida; fortaleceu as ações dos professores e alunos no uso de tecnologias com intencionalidade educativa. A pesquisadora, os professores e os alunos mapearam informações, narraram ao planejar seus projetos e atividades, estabeleceram relações de sentido e significado por meio de comunicações hipertextuais apoiadas por TDIC.

As atividades pedagógicas nas Oficinas de Orientação de Estudos referenciadas pelo Letramento Digital foram planejadas a partir dos conhecimentos existentes e relevantes, tanto dos professores, como dos alunos, consideradas as condições adversas encontradas nas dimensões do contexto escolar (infraestrutura, administrativa-pedagógica, didática-pedagógica e pessoal).

As TDIC foram selecionadas não como um mero recurso digital, visto que os professores e alunos ampliaram as potencialidades de seu uso na própria elaboração dos seus projetos e atividades. Vale ressaltar a capacidade de buscar e selecionar as informações, compreendê-las, apreendê-las e contextualizá-las para construção de conhecimentos gerais e no atendimento das demandas diversas das disciplinas curriculares de maneira ética.

As dificuldades de infraestrutura tecnológica, por exemplo, foram desafiadoras e estratégias alternativas foram buscadas como a perspectiva do BYOD, com uso dos celulares dos participantes, na superação das limitações de acesso pelo reduzido número de computadores.

As dificuldades de comunicação internas foram sanadas com as estratégias de comunicação síncrona e assíncrona em redes sociais com trocas de experiências e diálogos bem-sucedidos entre os participantes. Tal atividade fortaleceu a interação pesquisadora/participantes, professor/aluno e aluno/aluno sob uma perspectiva nãohierárquica, característica da sala de aula tradicional.

O Letramento Digital como referência para a elaboração do Design pedagógico gerou oportunidades para reflexão sobre o que ensinar/aprender, o como, o por que, o com e o que, entre tantos questionamentos essenciais ao planejamento e ao enfrentamento das transformações advindas com a presença das TDIC. 
Essa situação evidenciou a importância de compreender e fazer uso daquilo que compreende com a leitura mediada pelas TDIC. Eis o grande desafio no processo de ensino-aprendizagem, desde o Ensino Fundamental, ou seja, possibilitar aos alunos:

O exercício de pensar o tempo, de pensar a técnica, de pensar o conhecimento enquanto conhece, de pensar o quê das coisas, o para quê, o como, o em favor de quê, de quem, o contra quê, o contra quem exigências fundamentais de uma educação democrática à altura dos desafios do nosso tempo. (FREIRE, 2000, p. 102).

No desenvolvimento da investigação procurou-se imprimir a compreensão do Letramento Digital com o exercício da articulação dos conhecimentos pedagógicos, tecnológicos e dos conteúdos das Oficinas; a integração de conhecimentos e habilidades de caráter computacional, informacional, multimidiática e comunicacional; e o envolvimento com a dimensão socioafetiva, como por exemplo, o interesse em usar TDIC, a curiosidade em pesquisar na Internet, em buscar novos aplicativos, a disciplina e os cuidados com a segurança na navegação na Internet, o zelo com equipamentos e a ética no tratamento da informação etc.

Nessa direção, o uso pedagógico das TDIC nas Oficinas foi experimentado de forma teórica e prática. A atuação junto aos alunos, em apoio aos professores, no acompanhamento das atividades com TDIC e os trabalhos escolares realizados sinalizaram à pesquisadora resultados práticos da investigação. Mesmo assim, as ações formadoras em TDIC e suas possíveis relações com o desenvolvimento das aprendizagens dos alunos exige um percurso longo e reflexivo.

O cenário composto com a pesquisa-ação sinalizou resultados que contêm contribuições para o amadurecimento e ampliação de reflexões sobre o tema. $\mathrm{Na}$ trajetória da pesquisa, a discussão sistemática com o Grupo Alph@ para elaboração de instrumentos de coleta de dados e reflexão sobre alternativas de uso das TDIC no Ensino Fundamental II concedeu à pesquisadora a compreensão do sentido de se pensar coletivamente (e junto a escolas) projetos em caráter de pesquisa e extensão nos cursos de formação docente, visando atuar na formação permanente de professores em local de trabalho, de modo contextualizado, enriquecendo inclusive a academia.

A viabilidade da pesquisa-ação trouxe contribuição para os processos de mudanças nas práticas pedagógicas nessa escola. Ao envolver os participantes da pesquisa na resolução de situações problemas permitiu integrar ensino, pesquisa e extensão. 
O desenvolvimento da cultura digital escolar a serviço de uma formação cidadã não tem mais tempo para ser tratado de forma isolada e sem um planejamento pedagógico contextualizado.

As categorias de Letramento Digital desenvolvem competências necessárias à participação na sociedade atual, e, por isso, devem ser compreendidas como um continuum, que abarca desde as ações de busca de informações ao compartilhamento ético de conhecimento, construído em diversos contextos e mídias.

A escola é uma instância para tratar com intencionalidade educativa os recursos informacionais e comunicacionais, mediante estratégias de desenvolvimento de competências que promovam novas formas de agir no mundo e a tomada de decisões na solução de problemas.

Ressalta-se, no entanto, a importância de um design pedagógico na Educação Escolar que equilibre atividades relevantes com TDIC e recursos físicos, dada a vasta disponibilidade de materiais didáticos não-desperdiçáveis, como os impressos em geral, objetos físicos e de outras naturezas, independente das condições contextuais das escolas.

Esta investigação conclui e reafirma que a formação docente deve ser permanente, com o objetivo de estimular a autonomia dos sujeitos na era digital, por meio de uma educação necessária à construção de uma sociedade justa, democrática e inclusiva.

O olhar reflexivo sobre o Letramento Digital apoiado pelo Design pedagógico sugere a continuidade de estudos nessa temática no contexto escolar, dada a sua complexidade. Por fim, a reflexão sobre a intencionalidade educativa do Design pedagógico no processo de Letramento Digital no Ensino Fundamental significa também refletir sobre as transformações da escola e pensar o futuro da Educação Escolar. 


\section{REFERÊNCIAS ${ }^{66}$}

AGUADED, Ignacio; MARÍN-GUTIÉRREZ, Isidro; DÍAZ-PAREJO, Elena. La alfabetización mediática entre estudiantes de primaria y secundaria em Andalucía (España). RIED. Revista Iberoamericana de Educación a Distancia [online], v. 18, n. 2, p. 275-298, 2015. Disponível em:

<http://www.redalyc.org/articulo.oa?id=331439257012>. Acesso em: 11 jan. 2016.

ALBUQUERQUE, Eliana Borges Correia de. Conceituando alfabetização e letramento. In: SANTOS, Carmi Ferraz; MENDONÇA, Márcia (Org.). Alfabetização e letramento: conceitos e relações. Belo Horizonte: Autêntica, 2007. p. 11-21.

ALMEIDA, Maria Elizabeth Bianconcini de; VALENTE, José Armando. Tecnologias e currículo: trajetórias convergentes ou divergentes? São Paulo: Paulus, 2011.

ARAÚJO, Verônica Danieli Lima; GLOTZ, Raquel Elza Oliveira. Letramento digital como instrumento de inclusão social e democratização do conhecimento: desafios atuais. Educação pública, Rio de janeiro, 2014. Disponível em:

<http://www.educacaopublica.rj.gov.br/>. Acesso em: 26 out. 2015.

ASSOCIAÇÃO BRASILEIRA DE NORMAS TÉCNICAS. NBR 5891: regras de arredondamento na numeração decimal. Rio de Janeiro, 2014.

. NBR 6323: informação e documentação: referencias: elaboração. Rio de Janeiro, 2002.

ATHENIENSE, Alexandre. Tecnologia na escola e direitos autorais em sala de aula. 2013. Disponível em: <https://www.conjur.com.br/2013-jun-28/direito-papeltecnologia-escola-direitos-autorais-sala-aula>. Acesso em: 13 nov. 2015.

BARDIN, Laurence. Análise de conteúdo. São Paulo: Edições 70, 2011.

BARTON, David; HAMILTON, Mary. Local literacies: reading and writing in one community. London: Routledge,1998.

BAUER, Martin W. Análise de conteúdo clássica: uma revisão. In: BAUER, Martin. W; GASKELL, George (Org.). Pesquisa qualitativa com textos: imagem e som: um manual prático. Tradução de Pedrinho A. Guareschi. 9. ed. Petrópolis: Vozes, 2011. p. 189-217.

BAWDEN, David. Origins and concepts of Digital Literacy. In: LANKSHEAR, Colin; KNOBEL, Michele (Org.). Digital literacies: concepts, policies and practices. New York: Peter Lang Publishing, 2008. p. 17-32.

${ }^{66}$ De acordo com a ABNT NBR 6023/2002. 
BAWDEN, David. Revisión de los conceptos de alfabetización informacional y alfabetización digital. Anales de Documentación, v. 5, p. 361-408, 2002. Disponível em: <http://revistas.um.es/analesdoc/article/view/2261/2251>. Acesso em: 18 out. 2015.

BECHARA, João José Bignetti. Design thinking: estruturantes téoricometodológicos impulsionadores da inovação escolar. 2017. 130 f. Tese (Doutorado em Educação) - Universidade de São Paulo, São Paulo, 2017.

BRANSFORD, John D.; BROWN, Ann L.; COCKING, Rodney R. (Org.). Como as pessoas aprendem. São Paulo: Senac, 2007.

BRASIL. Constituição (1988). Constituição da República Federativa do Brasil. Brasília, DF: Senado, 1988.

Decreto $n^{\circ} 6.300$, de 12 de dezembro de 2007, que dispõe sobre o Programa Nacional de Tecnologia Educacional - Prolnfo. Diário Oficial [da] União, Brasília, DF, 13 dez. 2007. Disponível em: <http://www.planalto.gov.br>. Acesso em: 3 abr. 2016.

. Decreto $n^{\circ} 6.424$, de 4 de abril de 2008, que altera e acresce dispositivos ao Anexo do Decreto $n^{\circ} 4.769$, de 27 de junho de 2003, que aprova o Plano Geral de Metas para a Universalização do Serviço Telefônico Fixo Comutado prestado no Regime Público - PGMU. Diário Oficial [da] União, Brasília, DF, 7 abr. 2008. 2008a. Disponível em: <http://www2.camara.leg.br/>. Acesso em: 3 abr. 2016.

. Decreto $n^{\circ} 7.083$, de 27 de janeiro de 2010, que dispõe sobre o Programa Mais Educação. Diário Oficial [da] União, Brasília, DF, 27 jan. 2010. 2010a. Disponível em: <http://www.planalto.gov.br/>. Acesso em: 15 abr. 2016.

Decreto $n^{\circ}$ 9.204, de 23 de novembro de 2017, que institui o Programa de Inovação Educação Conectada. Diário Oficial [da] União, Brasília, DF, 24 nov. 2017. 2017a. Disponível em: <http://portal.mec.gov.br>. Acesso em: 4 mar. 2018.

. Lei $n^{\circ}$ 9.394, de 20 de dezembro de 1996, que estabelece as Diretrizes e Bases da Educação Nacional. Diário Oficial [da] União, Brasília, DF, 23 dez.1996.

. Lei $n^{\circ}$ 9.610, de 19 de fevereiro de 1998, que altera, atualiza e consolida a legislação sobre direitos autorais e dá outras providências. Diário Oficial [da] União, Brasília, DF, 20 fev.1998. Disponível em: <http://www.planalto.gov.br/>. Acesso em: 30 dez. 2015.

. Lei $\mathrm{n}^{\circ} 12.249$, de 11 de junho de 2010, que cria o Programa um computador por aluno (Prouca). Diário Oficial [da] União, Brasília, DF, 14 jun. 2010. 2010b. Disponível em: <http://www.planalto.gov.br/ccivil_03/_Ato20072010/2010/Lei/L12249.htm>. Acesso em: 3 abr. 2016. 
BRASIL. Conselho Nacional de Educação. Resolução $n^{\circ} 2$, de $1^{\circ}$ de julho de 2015 , que define as Diretrizes Curriculares Nacionais para a formação inicial em nível superior e para a formação continuada. 2015. Disponível em: <http://portal.mec.gov.br/>. Acesso em: 6 out. 2016.

BRASIL. Ministério de Educação. Secretaria de Educação Básica. Base Nacional Comum Curricular (BNCC). 2017b. Disponível em:

<http://basenacionalcomum.mec.gov.br>. Acesso em: 4 fev. 2018.

. Diretrizes Curriculares Nacionais Gerais para a Educação Básica.

2013a. 542 p. Disponível em: <http://portal.mec.gov.br>. Acesso em: 6 abr. 2016.

. Guia de tecnologias educacionais da educação integral e integrada e da articulação da escola com seu território 2013. 2013b. 55 p. Disponível em: <http://portal.mec.gov.br/>. Acesso em: 16 out. 2015.

Guia de tecnologias MEC 2009. 2009. 170 p. Disponível em:

<http://portal.mec.gov.br/dmdocuments/guia_tecnologias_atual.pdf>. Acesso em: 16 out. 2015.

. Guia de tecnologias MEC 2011/2012. 2011. 196 p. Disponível em:

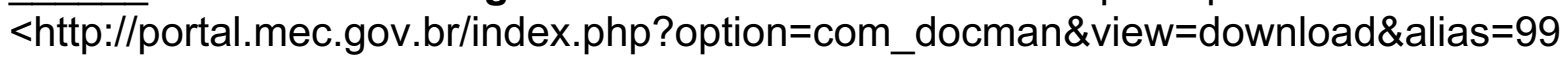
09-guias-tecnologias-2011-12\&Itemid=30192>. Acesso em: 16 out. 2015.

. Portal do professor. 2008b. Disponível em:

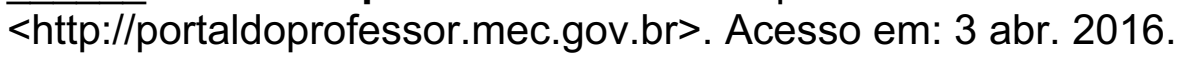

. Programa Banda Larga nas Escolas (PBLE). 2008c. Disponível em:

http://portal.mec.gov.br/programa-saude-da-escola/193-secretarias-

112877938/seed-educacao-a-distancia-96734370/15808-programa-banda-larga-nasescolas . Acesso em: 3 abr. 2016.

. Programas de ações. [2018a]. Disponível em:

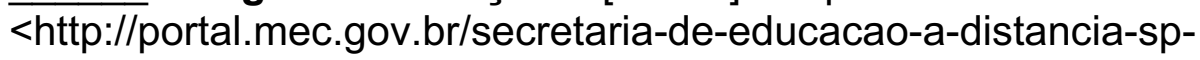

2090341739/programas-e-acoes>. Acesso em: 8 fev. 2018.

. Programa de Inovação Educação Conectada. 2017c. Disponível em: <http://portal.mec.gov.br/>. Acesso em: 4 fev. 2018.

. Programa Nacional de Formação Continuada em Tecnologia

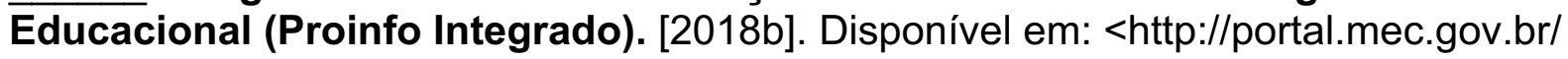
mid=823>. Acesso em: 8 fev. 2018.

Um computador por aluno. 2008d. Disponível em:

$\overline{<\mathrm{http} / / / p o r t a l . m e c . g o v . b r / c o m p o n e n t / c o n t e n t / a r t i c l e / 222-n o t i c i a s / 537011943 / 11833-}$ sp-1083123162? Itemid=164>. Acesso em: 3 abr. 2016.

. Secretaria de Educação Fundamental. Parâmetros Curriculares

Nacionais: introdução aos parâmetros curriculares nacionais. Brasília, DF, 1997a. 
BRASIL. Ministério de Estado da Educação e do Desporto. Portaria Ministerial $\mathrm{n}^{\circ}$ 522, de 9 de abril de 1997, que cria o Programa Nacional de Informática na Educação (Proinfo). 1997b. Disponível em:

<http://www.dominiopublico.gov.br/download/texto/me001167.pdf>. Acesso em: 3 abr. 2016.

. Ministério de Estado da Educação e do Desporto. Secretaria de Educação

Média e Tecnológica. Programa Nacional de Informática Educativa (Proninfe).

Brasília, DF, 1994. Disponível em: <http://www.dominiopublico.gov.br/>. Acesso em: 3 abr. 2016.

. Ministério da Saúde. Conselho Nacional de Saúde. Resolução n 466, de 12 de dezembro de 2012, que aprova diretrizes e normas regulamentadoras de pesquisas envolvendo seres humanos. 2012. Disponível em:

<http://bvsms.saude.gov.br/bvs/saudelegis/cns/2013/res0466_12_12_2012.html>. Acesso em: 3 jan. 2015.

BUCKINGHAM, David. Cultura digital, educação midiática e o lugar da escolarização. Educação \& Realidade [online], v. 35, n. 3, p. 37-58, set./dez. 2010. Disponível em: <http://www.redalyc.org/articulo.oa?id=317227078004>. Acesso em: 10 nov. 2015.

BUZATO, Marcelo El Khouri. Letramentos digitais e formação de professores. São Paulo: Educarede, 2006. Disponível em:

<http://www.educarede.org.br/educa/img_conteu-do/marcelobuzato.pdf>. Acesso em: 10 nov. 2015.

CAIADO, Roberta Varginha Ramos. Novas tecnologias digitais da informação e comunicação e o ensino-aprendizagem de língua portuguesa. 2011. 279 f. Tese (Doutorado em Educação) - Universidade Federal de Pernambuco, Recife, 2011.

CANCLINI, Néstor Gárcia. Culturas híbridas: estratégias para entrar e sair da modernidade. 4. ed. Tradução de Ana Regina Lessa e Heloísa Cintrão. São Paulo: EDUSP, 2003.

CASTELLS, Manuel. Sociedade em rede. São Paulo, Paz e Terra, 1999.

CAVICCHIOLI, Gabriela Spagnuolo. As competências audiovisuais e os novos letramentos na escola. 2015. 202 f. Dissertação (Mestrado em Educação) Universidade Federal de Santa Catarina, Florianópolis, 2015.

CENTRO DE INOVACAO PARA A EDUCACAO BRASILEIRA (CIEB). CIEB Estudos \#4: políticas de tecnologia na educação brasileira: histórico, lições aprendidas e recomendações. São Paulo, 2016a. v. 4. Disponível em: <http://www.cieb.net.br>. Acesso em: 24 jan. 2018.

. Resultados do Guia EduTec 2016: adoção de tecnologia nas redes estaduais de ensino. 2016b. Disponível em: http://www.cieb.net.br/wpcontent/uploads/2017/04/Relatório-Guia-EduTec.pdf . Acesso em: 24 jan. 2018. 
CENTRO REGIONAL DE ESTUDOS PARA O DESENVOLVIMENTO DA SOCIEDADE DA INFORMAÇÃO (Cetic.br). Publicações. 2011. Disponível em: <http://cetic.br/pesquisa/educacao/publicacoes/>. Acesso em: 12 abr. 2016.

CERUTTI-RIZZATTI, Mary Elizabeth. Letramento: uma discussão sobre implicações de fronteiras conceituais. Educação \& Sociedade, Campinas, v. 33, n. 118, p. 291305, mar. 2012. Disponível em:

<http://www.scielo.br/scielo.php?script=sci_arttext\&pid=S0101-

$73302012000100018 \&$ Ing=em\&nrm=em>. Acesso em: 18 jun. 2015.

CHIZZOTTI, Antonio. Pesquisa em ciências humanas e sociais. 11. ed. São Paulo: Cortez, 2010.

COLL, César; ILLERA, José Luis Rodríguez. Alfabetização, novas alfabetizações e alfabetização digital. In: COLL, César; MONERO, Carles (Org.). Psicologia da educação virtual: aprender e ensinar com as tecnologias da informação e da comunicação. Porto Alegre: Artmed, 2010. p. 289-310.

COMITÊ GESTOR DA INTERNET NO BRASIL (CGI.br). TIC Domicílios 2014: pesquisa sobre o uso das tecnologias de informação e comunicação em domicílios brasileiros. [livro eletrônico]. São Paulo: CGI.br, 2015a. Disponível em: <http://www.cetic.br/pesquisa/domicilios>. Acesso em: 12 abr. 2016.

TIC Educação 2014: pesquisa sobre o uso das tecnologias de informação e comunicação nas escolas brasileiras. [livro eletrônico]. São Paulo: CGI.br, 2015b. Disponível em: <http://www.cetic.br/publicacao>. Acesso em: 12 abr. 2016.

. TIC Educação 2016: pesquisa sobre o uso das tecnologias de informação e comunicação nas escolas brasileiras [livro eletrônico]. São Paulo: CGI.br, 2017. Disponível em: <http://cetic.br/publicacao>. Acesso em: 18 mar. 2018.

COORDENAÇÃO DE APERFEIÇOAMENTO DE PESSOAL DE NÍVEL SUPERIOR. Catálogo de teses e dissertações (CT.Capes). 2002. Disponível em:

<http://catalogodeteses.capes.gov.br/catalogo-teses/\#!/>. Acesso em: 11 jan. 2016.

COPE, Bill; KALANTZIS, Mary. (Ed.). Multiliteracies: literacy learning and the design of social futures. London: Routledge, 2000.

Multiliteracies: new literacies, new learning. Pedagogies: An International Journal, London, v. 4, n. 3, p. 164-195, jul. 2009. Disponível em:

<http://newlearningonline.com/_uploads/pedagogiesm-litsarticle.pdf>. Acesso em: 30 out. 2015.

COSCARELLI, Carla Viana; RIBEIRO, Ana Elisa (Org.). Alfabetização e letramento digital. In: COSCARELLI, Carla Viana; RIBEIRO, Ana Elisa (Org.). Letramento digital: aspectos sociais e práticas pedagógicas. 2. ed. Belo Horizonte: Ceale; Autêntica, 2007. p. 25-40. 
DAL PRÁ, Keli Regina; LIMA, Telma Cristiane Sasso de; MIOTO, Regina Célia Tamaso. A documentação no cotidiano da intervenção dos assistentes sociais: algumas considerações acerca do diário de campo. Revista Virtual Textos \& Contextos, v. 6, n. 1, p. 93-104, jan./jun. 2007.

DELLAGNELO, Lúcia. Inovação e tecnologia na educação: Guia Edutec - ferramenta de diagnóstico e planejamento de políticas de tecnologia educacional. In: COMITÊ GESTOR DA INTERNET NO BRASIL (CGI.br), 2017, São Paulo. TIC Educação 2016: pesquisa sobre o uso das tecnologias de informação e comunicação nas escolas brasileiras [livro eletrônico]. São Paulo: CGI.br, 2017. p. 33-39. Disponível em: <http://cetic.br/publicacao>. Acesso em: 18 mar. 2018.

DUDZIAK, Elisabeth Adriana. Information literacy: princípios, filosofia e prática. Ciência da Informação, Brasília, DF, v. 32, n. 1, p. 23-35, abr. 2003. Disponível em: $<$ http://www.scielo.br/scielo.php?script=sci_arttext\&pid=S0100$19652003000100003 \&$ Ing=en\&nrm=iso>. Acesso em: 9 set. 2015.

ESCOLA ESTADUAL FERNANDO NOBRE (EEFN). Blog Pesquisa Nobre. 2016. Disponível em: <http://pesquisanobre.blogspot.com>. Acesso em: 15 jan. 2018.

. Plano escolar. Cotia, SP. 2013.

ESTEVE MON, Francesc Marc; GISBERT CERVERA, Mercè. Explorando El Potencial Educativo de Los Entornos Virtuales 3d. Teoría de la Educación. Educación y Cultura em la Sociedad de la Información, v. 14, n. 3, p. 302-319, set./dez. 2013.

FERNÁNDEZ MORANTE, Carmen; CEBREIRO LÓPEZ, Beatriz; FERNÁNDEZ DELA IGLESIA, Carmen. Competencias para el aprendizaje em red de los alumnos de educación secundaria em Galicia. Pixel-Bit. Revista de Medios y Educación [online], n. 38, p. 7-21, jan. 2011. Disponível em:

<http://redalyc.org/articulo.oa?id=36816200001>. Acesso em: 11 jan. 2016.

FERREIRA, Jalmelice da Luz. Os usos das TICs no desenvolvimento da leitura e escrita no Ensino Fundamental. 2012. 106 f. Dissertação (Mestrado em Educação) - Universidade do Estado de Minas Gerais, Belo Horizonte, 2012.

FERREIRA, José Luis. Moodle: um espaço de interação e aprendizagem. In: COSTA, Maria Luisa Furlan; ZANATTA, Regina Maria (Org.). Educação a distância no Brasil: aspectos históricos, legais, políticos e metodológicos. 2. ed. Maringá: Eduem, 2010. p. 57-76.

FLICK, Uwe. Introdução à pesquisa qualitativa. 3. ed. Porto Alegre: Artmed, 2009. $405 \mathrm{p}$.

FRADE, Isabel Cristina A. da Silva. Alfabetização digital: problematização do conceito e possíveis relações com a pedagogia e com aprendizagem inicial do sistema de escrita. In: COSCARELLI, Carla Viana; RIBEIRO, Ana Elisa (Org.). Letramento digital: aspectos sociais e práticas pedagógicas. 2. ed. Belo Horizonte: Ceale; Autêntica, 2007. p. 59-84. 
FREIRE, Paulo. A importância do ato de ler em três artigos que se complementam. São Paulo: Cortez, 2003.

FREIRE, Paulo. O futuro da escola. In: FREIRE, Paulo; PAPERT, Seymour. Diálogo entre Paulo Freire e Seymour Papert. São Paulo: TV PUC-SP, 1995. Disponível em: <https://www.youtube.com/>. Acesso em: 22 jun. 2018.

. Pedagogia da autonomia: saberes necessários à prática educativa. São Paulo: Paz e Terra, 1996.

. Pedagogia da indignação: cartas pedagógicas e outros escritos. São Paulo: UNESP, 2000.

. Pedagogia do oprimido. 17. ed. Rio de Janeiro: Paz e Terra, 1987.

FREITAS, Maria Teresa. Letramento digital e formação de professores. Educação em Revista, Belo Horizonte. v. 26, n. 3, p. 335-352, dez. 2010. Disponível em: <http://dx.doi.org/10.1590/S0102-46982010000300017>. Acesso em: 30 dez. 2015.

FUSARI, José Cerchi. O planejamento do trabalho pedagógico: algumas indagações e tentativas de respostas. Centro de Referência em Educação, 1990. p. 44-53. Disponível em: <http://www.crmariocovas.sp.gov.br/dir_a.php?t=014>. Acesso em: 25 set. 2016.

GASQUE, Kelley Cristine Gonçalves Dias. Arcabouço conceitual do letramento informacional. Ciência da Informação, Brasília, DF, v. 39 n. 3, p. 83 a 92, set./dez. 2010.

GATTI, Bernadete Angelina. Grupo focal na pesquisa em ciências sociais e humanas. Brasília, DF: Líber Livro, 2005.

GEE, James Paul. A situated sociocultural approach to literacy and technology. 2009. Disponível em: <http://jamespaulgee.com>. Acesso em: 9 set. 2015.

Getting over the slump: innovation strategies to promote children's learning. New York: The Joan Ganz Cooney Center at Sesame Workshop, 2008.

. Opportunity to learn: a language-based perspective on assessment. Assessment in Education, v. 10, p. 25-44, 2003.

Situated language and learning: a critique of traditional schooling. London:

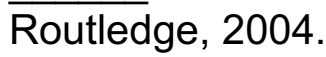

. The New Literacy Studies: From "socially situated" to the work of the social. In: BARTON, David.; HAMILTON, Mary; IVANIC, R. (Ed.). Situated literacies: reading and writing in context. London: Routledge. 2000. p. 180-196.

What video games have to teach us about learning and literacy. 2. ed. New York: Palgrave/Macmillan, 2007. 
GIL, Antonio Carlos. Como elaborar projetos de pesquisa. 4. ed. São Paulo: Atlas, 2002.

GILSTER, Paul. Digital literacy. New York: John Wiley, 1997.

GUIMARÃES, Liliana Andolpho. M. et al. Os métodos qualitativo e quantitativo: similaridades e complementaridade. In: GRUBITS, Sonia; NORIEGA, José Angel Vera (Org.). Método qualitativo: epistemologia, complementaridades e campos de aplicação. São Paulo: Vetor, 2004. p. 79-92.

HERNÁNDEZ, Fernando; VENTURA, Montserrat. A organização do currículo por projetos de trabalho. 5. ed. Porto Alegre: Artes Médicas, 1998.

HOFFMANN, Jussara. Avaliar para promover: as setas do caminho. Porto Alegre: Mediação, 2001.

INSTITUTO BRASILEIRO DE INFORMAÇÃO EM CIÊNCIA E TECNOLOGIA. Biblioteca digital brasileira de teses e dissertações (BDTD.IBICT). 2002. Disponível em: <http://bdtd.ibict.br>. Acesso em: 12 jan. 2016.

INSTITUTO NACIONAL DE ESTUDOS E PESQUISAS EDUCACIONAIS ANÍSIO TEIXEIRA (INEP). Censo Escolar 2016: notas estatísticas. 2017. 28 p. Disponível em:

<http://download.inep.gov.br/educacao_basica/censo_escolar/notas_estatisticas/201 7/notas_estatisticas_censo_escolar_da_educacao_basica_2016.pdf $>$. Acesso em: 30 abr. 2018.

KLEIMAN, Angela B. Modelos de letramento e as práticas de alfabetização na escola. In: KLEIMAN, Angela B. (Org.). Os significados do letramento: uma nova perspectiva sobre a prática social da escrita. Campinas, SP: Mercado de Letras, 1995. p. 15-61.

. Preciso "ensinar" o letramento?: não basta ensinar a ler e escrever? Brasília: MEC, 2005.

KNOBEL, Michele; LANKSHEAR, Colin. Critical cyberliteracies: what young people can teach us about reading and writing the world. New York, p. 22-24, fev. 2002.

Disponível em: <http://everydayliteracies.net/files/cyberliteracies.html>. Acesso em: 10 set. 2015.

. Studying New Literacies. Journal of Adolescent \& Adult Literacy, v. 58, Issue 2, 2014. Disponível em:

<http://onlinelibrary.wiley.com/doi/10.1002/jaal.314/epdf>. Acesso em: 10 set. 2015.

$\mathrm{KOCH}$, Ingedore Guerfeld Villaça. Ler e compreender os sentidos do texto. São Paulo: Contexto, 2007.

LANKSHEAR, Colin; KNOBEL, Michele (Org.). Digital literacies: concepts, policies and practices. New York: Peter Lang Publishing, 2008. p. 17-32, 2008. 
LANKSHEAR, Colin et al. A new literacies sampler: new literacies and digital epistemologies. New York: Peter Lang, 2007a.

LANKSHEAR, Colin; KNOBEL, Michel. The "Stuff" of new literacies. James Cook University and McGill University, 2007b. p. 1-15. Disponível em:

<http://everydayliteracies.net/files/stuff.pdf>. Acesso em: 8 set. 2015.

LÉVY, Pierre. A inteligência coletiva. São Paulo: Edições Loyola, 1998a.

. A máquina universo. Porto Alegre: Artmed, 1998b.

As tecnologias da inteligência: o futuro do pensamento na era da

informática. Rio de Janeiro: Editora 34, 1993.

. Cibercultura. São Paulo: Editora 34, 1999.

LIBÂNEO, J. C. Didática. São Paulo: Loyola, 2010.

LONGARZO, Jussara Cascaes. Letramento digital na voz dos professores de língua portuguesa dos anos finais do Ensino Fundamental. 2016. $128 \mathrm{f}$. Dissertação (Mestrado em Educação) - Universidade da Região de Joinville, Joinville, 2016.

MACHADO, Nílson José. Conhecimento como um valor: ensaios sobre economia, ética e educação. São Paulo: Livraria da Física, 2015.

. Imagens do conhecimento e ação docente no ensino superior. São

Paulo: Pró-reitoria de Graduação da Universidade de São Paulo, 2008. p. 47-62.

MARCUSCHI, Luiz Antonio. Gêneros textuais emergentes no contexto da tecnologia digital. In: MARCUSCHI, Luiz Antonio; XAVIER, Antonio Carlos (Org.). Hipertexto e gêneros digitais. Rio de Janeiro: Lucerna, 2004. p. 15-80.

MÉKSENAS, Paulo. Aspectos metodológicos da pesquisa empírica: a contribuição de Paulo Freire. Revista Espaço Acadêmico, Maringá, PR, ano 7, n. 78, nov. 2007.

MESCK, Ana Paula de Deus. As perspectivas do professor de língua materna nos anos finais do Ensino Fundamental a partir da implantação do Programa um computador por aluno (PROUCA). 2014. 193 f. Dissertação (Mestrado Profissional em Educação e Tecnologia) - Instituto Federal de Educação, Ciência e Tecnologia. Sul-Rio-Grandense, Pelotas, 2014.

MINAYO, Maria Cecília de Souza. O desafio da pesquisa social. In: MINAYO, M. C. S. (Org.). Pesquisa social: teoria, método e criatividade. 29. ed. Petrópolis: Vozes, 2010. p. 9-30.

MIRANDA, Guacira Quirino. Crônicas animadas na educação digital. 2013. 142 f. Dissertação (Mestrado em Educação) - Universidade Federal de Uberlândia, Uberlândia, 2013. 
MISHRA, Punya; KOEHLER, Mattew J. Technological Pedagogical Content Knowledge: a framework for teacher knowledge. Teachers College Report, Nova York, v. 108, n. 6, p. 1017-1054, 2006.

. What is technological Pedagogical content knowledge? Contemporary Issues in Technology and Teacher Education, v. 9, n. 1, p. 60-70, 2009.

MORAN, José Manuel. Ensino e aprendizagem inovadores com tecnologias audiovisuais e telemáticas. In: MORAN, José Manuel; MASSETTO, Marcos T.; BEHRENS, Marilda Aparecida. Novas tecnologias e mediação pedagógica. 10. ed. Campinas: Papirus, 2006. p. 11-66.

NAKASHIMA, Rosária Helena Ruiz. A dialética dos conhecimentos pedagógicos dos conteúdos tecnológicos e suas contribuições para a ação docente e para o processo de aprendizagem apoiados por ambiente virtual. 2014. 287 p. Tese (Doutorado em Educação) - Universidade de São Paulo, São Paulo, 2014.

NEW MEDIA CONSORTIUM (NMC). Horizon report. 2004. Disponível em: <https://www.nmc.org>. Acesso em: 13 maio 2016.

MNC/CoSN horizon report: 2017 K-12 Edition. 2017. Disponível em:

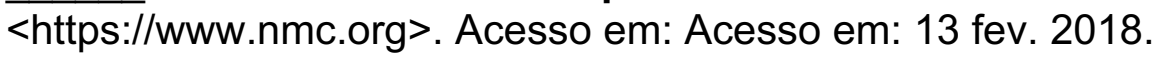

NOVAK, Joseph D.; CAÑAS, Alberto J. A teoria subjacente aos MC e como elaborálos e usá-los. Práxis Educativa, Ponta Grossa, v. 5, n. 1, p. 9-29, jan./jun. 2010.

PEREIRA, Adalberto Bosco Castro. Uso de jogos digitais no desenvolvimento de competências curriculares da matemática. 2017. $161 \mathrm{f}$. Tese (Doutorado em Ciências da Computação) - Universidade de São Paulo, São Paulo, SP, 2017.

PÉREZ GÓMEZ, Ángel I. Educação na era digital: a escola educativa. Porto Alegre: Penso, 2015. 192 p.

PÉREZ TORNERO, José Manuel. Promoting digital literacy: final report. EAC/76/03. Understanding digital literacy. Unión Europea. Educacion y Cultura. 2004. Disponível em:

<https://www.researchgate.net/publication/271505720_Jose_Manuel_Perez_Tornero _Promoting_Digital_Literacy>. Acesso em: 29 set. 2016.

PIAGET, Jean. Seis estudos de psicologia. Tradução de Maria Alice Magalhães D’Amorim e Paulo Sérgio Lima Silva. 24. ed. Rio de Janeiro: Forense Universitária, 1999.

PICONEZ, Stela Conceição Bertholo. Aprendizagem cooperativa apoiada por recursos da Internet como estratégia de educação permanente e qualificação interdisciplinar. Cadernos pedagógicos reflexões: educação \& tecnologia \& cidadania: ambientes de aprendizagem no ciberespaço. São Paulo, v. 1, n. 6, p. 8189, 2004. 
PICONEZ, Stela Conceição Bertholo et al. Formação permanente de educadores, recursos educacionais abertos (REA) e integração dos conhecimentos. In: OKADA, Alexandra. (Org.). Recursos educacionais abertos \& redes sociais. 2. ed. São Luís: EDUEMA, 2014. p. 321-293.

PIMENTA, Viviane Raposo; PEREIRA, Leonardo Moreira. Letramento digital como requisto para a inclusão digital e o exercício da cidadania. Anais ... In: Simpósio Internacional de Educação a Distância, 2012, São Paulo: UFSCar. Disponível em: <https://www2.ufscar.br>. Acesso em: 25 out. 2015.

PIRES, Robson Miguel. Letramento digital em livros didáticos de língua portuguesa. 2016. 132 f. Dissertação (Mestrado em Educação) - Universidade Federal de Uberlândia, Uberlândia, 2016.

QUIVY, Raymond; CAMPENHOUDT, Luc Van. Manual de investigação em ciências sociais. Tradução de João Minhoto Marques; Maria Amália Mendes; Maria Carvalho. 5. ed. Lisboa: Gradiva, 2008. 282 p.

RED DE REVISTAS CIENTÍFICAS DE AMÉRICA LATINA Y EL CARIBE, ESPAÑA Y PORTUGAL (Redalyc). Colección de revistas. 2003. Disponível em: <http://www.redalyc.org>. Acesso em: 3 mar. 2016.

RIOS, Maria de Fátima Serra et al. Letramento digital na prática pedagógica e segurança no uso de celulares. Anais ... In: WEB CURRÍCULO, 5., 2017, São Paulo: PUCSP. Disponível em: <http://www.pucsp.br/webcurriculo/anais.html>. Acesso em: 2 jan. 2018.

ROJO, Roxane. Letramentos múltiplos, escola e inclusão social. São Paulo: Parábola Editorial, 2009.

. Pedagogia dos multiletramentos: diversidade cultural e de linguagens na escola. In: ROJO, Roxane; MOURA, Eduardo. (Org.). Multiletramentos na escola. São Paulo: Parábola, 2012. p. 11-31.

; BARBOSA, Jacqueline P. Hipermodernidade, multiletramentos e gêneros discursivos. São Paulo: Parábola Editorial, 2015. 152 p.

SALCIDO, Alejandra Silva. Linguagem escrita, habilidades metacognitivas e tecnologia digital: uma relação em construção. 2016. 352 f. Dissertação (Mestrado em Educação) - Universidade Estadual de Campinas, Campinas, 2016.

SALVADOR, César Coll. Aprendizagem escolar e construção do conhecimento. Tradução de Emília de Oliveira Dihel. Porto Alegre: Artes Médicas, 1994.

SÁNCHEZ ANTOLÍN, Pablo; MUÑOZ ÁLVAREZ, Tania; PAREDES LABRA, Joaquín. El trabajo em el aula y la competencia digital em el modelo 1 a 1 de la comunidad de Madrid. Pixel-Bit. Revista de Medios y Educación [online], n. 47, p. 211-222, jul. 2015. Disponível em: <http://redalyc.org/articulo.oa?id=36841180014>. Acesso em: 11 jan. 2016. 
SÃO PAULO (Estado). Assembleia Legislativa do Estado de São Paulo. Decreto $n^{\circ}$ 52.625 , de 15 de janeiro de 2008, que regulamenta o uso de telefone celular nos estabelecimentos de ensino do Estado de São Paulo. 2008. Disponível em: $<$ http://www.al.sp.gov.br>. Acesso em: 25 mar. 2016.

Decreto $\mathrm{n}^{\circ} 57.571$, de 2 de dezembro de 2011, que institui, junto à Secretaria da Educação, o Programa Educação - Compromisso de São Paulo e dá providências correlatas. 2011. Disponível em: $<$ https://www.al.sp.gov.br/repositorio/legislacao/decreto/2011/decreto-5757102.12.2011.html>. Acesso em: 16 jun. 2016.

. Lei $\mathrm{n}^{\circ} 12.730$, de 11 de janeiro de 2007, que proíbe o uso de telefone celular nos estabelecimentos de ensino do Estado, durante o horário de aula. 2007a. Disponível em: <https://www.al.sp.gov.br/repositorio/legislacao/lei/2007/alteracao-lei12730-11.10.2007.html>. Acesso em: 25 mar. 2016.

. Lei $\mathrm{n}^{\circ} 16.567$, de 06 de novembro de 2017, que altera a Lei $\mathrm{n}^{\circ} 12.730$, de 11 de outubro de 2007, que proíbe o uso de telefone celular nos estabelecimentos de ensino do Estado, durante o horário de aula. Diário Oficial [do] Estado de São Paulo, 7 nov. 2017. 2017a. Disponível em:

<http://dobuscadireta.imprensaoficial.com.br/default.aspx?DataPublicacao=2017110 7\&Caderno=DOE-I\&NumeroPagina=1>. Acesso em 5 jan. 2018.

. Lei Complementar $n^{\circ} 1.093$, de 16 de julho de 2009, que dispõe sobre a contratação por tempo determinado de que trata o inciso $\mathrm{X}$ do artigo 115 da Constituição Estadual. Diário Oficial [do] Estado de São Paulo, 17 jul. 2009. Disponível em: $<$ http://dobuscadireta.imprensaoficial.com.br/default.aspx?DataPublicacao=2009071 7\&Caderno=DOE-I\&NumeroPagina=1>. Acesso em: 17 out. 2016.

. Lei Complementar $n^{\circ} 1.277$, de 22 de dezembro de 2015, que altera a Lei Complementar $n^{\circ} 1.093$, de 16 de julho de 2009, que dispõe sobre a contratação por tempo determinado de que trata o inciso $X$ do artigo 115 da Constituição Estadual. Diário Oficial [do] Estado de São Paulo, 23 dez. 2015. 2015a. Disponível em: <http://dobuscadireta.imprensaoficial.com.br/default.aspx?DataPublicacao=2015122 3\&Caderno=DOE-I\&NumeroPagina=1>. Acesso em: 17 out. 2016.

. Secretaria de Educação do Estado de São Paulo. Currículo do Estado de São Paulo. Disponível em: <http://www.educacao.sp.gov.br/curriculo>. 2008. Acesso em: 18 jun. 2016.

. Diretrizes do Programa Ensino Integral. São Paulo, 2012a.

Material de apoio ao currículo do Estado de São Paulo: caderno do aluno. História. $5^{\mathrm{a}}$ série/6ªno. São Paulo, 2014-2017. 2014a. v. 1.

. Material de apoio ao currículo do Estado de São Paulo: caderno do professor. História. $5^{a}$ série $/ 6^{\circ}$ ano. São Paulo, 2014-2017. 2014b. v. 1. 
SÃO PAULO (Estado). Secretaria de Educação do Estado de São Paulo. Recursos digitais articulados com o Currículo do Estado de São Paulo. 2012b. Disponível em: <http://curriculomais.educacao.sp.gov.br>. Acesso em: 18 jun. 2016.

. Resolução $n^{\circ} 6$, de 19 de janeiro de 2016, que dispõe sobre a organização curricular do Ensino Fundamental, nas Escolas de Tempo Integral - ETI, e dá providências correlatas. 2016a. Disponível em: <http://siau.edunet.sp.gov.br/ltemLise/arquivos/6_16.HTM>. Acesso em: 17 out. 2016.

. Resolução SE $n^{\circ} 6$, de 23 de fevereiro de 2015, que altera dispositivos da Resolução SE $n^{\circ} 52$, de 02 de outubro de 2014, que dispõe sobre a organização e o funcionamento das escolas estaduais do Programa Ensino Integral, de que trata a Lei Complementar 1.164, de 04 de janeiro de 2012, e dá providências correlatas. 2015b. Disponível em: <http://siau.edunet.sp.gov.br>. Acesso em: 17 out. 2016.

. Resolução SE n² 21, de 28 de abril de 2014, que institui o Programa Novas Tecnologias - Novas Possibilidades. 2014c. Disponível em: <http://www.educacao.sp.gov.br>. Acesso em: 16 ago. 2016.

. Resolução SE n 52 , de 2 de outubro de 2014, que dispõe sobre a organização e o funcionamento das escolas estaduais do Programa Ensino Integral, de que trata a Lei Complementar 1.164, de 4 de janeiro de 2012, e dá providências correlatas. 2014d. Disponível em: <http://siau.edunet.sp.gov.br>. Acesso em: 17 out. 2016.

. Resolução SE $n^{\circ} 76$, de 27 de dezembro de 2016, que altera a Resolução $\overline{\mathrm{SE} n^{\circ} 6}$, de 19 de janeiro de 2016, que dispõe sobre a organização curricular do Ensino Fundamental, nas Escolas de Tempo Integral - ETI, e dá providências correlatas. 2016b. Disponível em: <http://siau.edunet.sp.gov.br>. Acesso em: 17 out. 2017.

. Resolução SE $n^{\circ} 89$, de 09 de dezembro de 2005, que dispõe sobre o Projeto Escola de Tempo Integral. 2005. Disponível em: <http://siau.edunet.sp.gov.br>. Acesso em: 17 out. 2016.

. Notícias: a escola que queremos: pesquisa elaborada por alunos da E.E. Fernando Nobre, de Cotia, aponta 36 malefícios causados à saúde por causa do aparelho, 2017b. Disponível em: <http://www.educacao.sp.gov.br/noticia/boaspraticas/alunos-aprendem-a-usar-celular-de-forma-consciente/>. Acesso em: 24 jan. 2018.

. Coordenadoria de Estudos e Normas Pedagógicas. Escola de tempo Integral. Oficina de orientação para estudo e pesquisa: caderno de apoio. São Paulo: SE/CENP, 2007b.

Coordenadoria de Gestão da Educação Básica. Documento orientador planejamento 2016. São Paulo: SE/CGEB, 2016c. 
SCHONZ, Mariane Maria. O laptop educacional na sala e aula: movimentos de letramento digital nas práticas de leitura e escrita de estudantes do Ensino Fundamental. 2013. 96 f. Dissertação (Mestrado em Educação) - Universidade de Caxias do Sul, Caxias do Sul, 2013.

SCHÖN, Donald Alan. Educando o profissional reflexivo: um novo design para o ensino e a aprendizagem. Tradução Roberto Cataldo Costa. Porto Alegre: Artmed, 2000.

SCIENTIFIC ELECTRONIC LIBRARY ONLINE (SciELO). [Search article]. 1998. Disponível em: <http://www.scielo.org>. Acesso em: 3 mar. 2016.

SEVERINO, Antonio Joaquim B. Metodologia do trabalho científico. São Paulo: Cortez, 2007.

SHULMAN, Lee S. Knowledge and teaching: foundations of the New Reform. Harvard Educational Review, Massachusetts, v. 57, n. 1, p. 1-22, fev. 1987.

. Those who understand: Knowledge growth in teaching. Educational Researcher, Whashington DC, v. 15, n. 2, p. 4-14, 1986.

SILVA, Ana Cristina Barbosa da. Softwares educativos: critérios de avaliação a partir dos discursos da interface, da esfera comunicativa e do objeto de ensino. 2012 346 f. Tese (Doutorado em Educação) - Universidade Federal de Pernambuco, Recife, 2012.

SOARES, Magda. Letramento: um tema em três gêneros. 3. ed. Belo Horizonte: Autêntica, 2014.

. Linguagem e escola: uma perspectiva social. São Paulo: Ática, 1996.

. Novas práticas de leitura e escrita: letramento na cibercultura. Educação \& Sociedade, Campinas, v. 23, n. 81, p. 143-160, 2002. Disponível em:

<http://www.scielo.br/pdf/es/v23n81/13935.pdf>. Acesso em: 12 abr. 2015.

SOUZA, Andréia Rabello de. O letramento digital no ensino da Matemática sob a perspectiva de complexidade. 2017. 134 f. Dissertação (Mestrado em Educação) Universidade Federal do Paraná, Curitiba, 2017.

STREET, Brian V. At last: recent applications of new literacy studies in educational contexts. Research in the Teaching of English, n. 39, p. 417-423, 2005.

STREET, Brian V. Introduction: the new literacy studies. In: STREET, Brian V. (Ed.). Cross-cultural approaches to literacy. New York: Cambridge University Press, 1993. p. 1-21.

Letramentos sociais: abordagens críticas do letramento no

desenvolvimento, na etnografia e na educação. São Paulo: Parábola, 2014. 
STREET, Brian V. Literacy in theory and practice. New York: Cambridge University Press, 1984.

Social literacies: critical approaches to literacy in development, ethnography, and education. London: Longman, 1995.

. The implications of the "new literacy studies" for literacy education. English in Education. n. 31, p. 45-59, 1997.

TFOUNI, Leda Verdiani. Adultos não-alfabetizados: o avesso do avesso. Campinas: Pontes, 1988.

. Letramento e alfabetização. 9. ed. São Paulo: Cortez, 2010.

THIOLLENT, Michel. Metodologia da pesquisa-ação. 18. ed. São Paulo: Cortez, 2011.

TOLEDO, Renata Ferraz de; JACOBI, Pedro Roberto. Pesquisa-ação e educação: compartilhando princípios na construção de conhecimentos e no fortalecimento comunitário para o enfrentamento de problemas. Educação \& Sociedade, Campinas, v. 34, n. 122, p. 155-173, mar. 2013. Disponível em: <http://www.scielo.br/pdf/es/v34n122/v34n122a09.pdf>. Acesso em: 24 fev. 2016.

TRIPP, David. Pesquisa-ação: uma introdução metodológica. Educação e Pesquisa, São Paulo. v. 31, n. 3, p. 443-466, dez. 2005. Disponível em: <http://www.scielo.br/pdf/ep/v31n3/a09v31n3.pdf.>. Acesso em: 24 abr. 2015.

TRIVIÑOS, Augusto Nibaldo da Silva. Introdução à pesquisa em ciências sociais: pesquisa qualitativa em Educação. São Paulo: Atlas, 2009.

UNESCO. Information for all programme. 2000. Disponível em:

<https://es.unesco.org/node/269926/sites>. Acesso em: 21 set. 2015.

. Padrões de competência em TIC para professores: diretrizes de implementação. Unesco, 2009a. Disponível em: <http://unesdoc.Unesco.org>. Acesso em: 21 set. 2015.

Padrões de competência em TIC para professores: marco político.

Unesco, 2009b. Disponível em:

<http://unesdoc.unesco.org/images/0015/001562/156210por.pdf>. Acesso em: 21 set. 2015.

UNIVERSIDADE DE SÃO PAULO. Biblioteca digital de teses e dissertações (BDTD.USP). São Paulo, 2001. Disponível em: <http://www.teses.usp.br.>. Acesso em: 10 jan. 2016.

VALENTE, José Armando; ALMEIDA, Fernando José de. Visão analítica da informática na educação no Brasil: a questão da formação do professor. Revista de Informática na Educação, v.1, n.1, p. 1-28. 1997. Disponível em: <http://www.brie.org/pub/index.php/rbie/article/view/2324/2083>. Acesso em: 11 abr. 2016. 
VASCONCELLOS, Celso. Planejamento: plano de ensino-aprendizagem e projeto educativo - elementos metodológicos para elaboração e realização. 21. ed. São Paulo: Libertad, 2010.

VEIGA, IIma Passos Alencastro (Org.). Projeto político-pedagógico da escola: uma construção possível. 24. ed. Campinas, SP: Papirus, 2008.

VELLOSO, Maria Jacy Maia. Letramento digital na escola: um estudo sobre a apropriação das interfaces da Web 2.0. 2010. 141 f. Dissertação (Mestrado em Educação) - Pontifícia Universidade Católica de Minas Gerais, Belo Horizonte, 2010.

VIGOTSKY, Lev Semenovich. A formação social da mente: o desenvolvimento dos processos psicológicos superiores. MICHAEL COLE et al. (Org.). Tradução de José Cipolla Neto, Luís Silveira Menna Barreto, Solange Castro Afeche. 7 ed. São Paulo: Martins Fontes, 2007.

XAVIER, Antonio Carlos. Letramento digital e ensino. Universidade Federal de Pernambuco: Núcleo de estudos de hipertexto e tecnologia educacional. 2007. Disponível em: <http://www.nehte.com.br/artigos/>. Acesso em: 12 abr. 2015.

. Letramento digital: impactos das tecnologias na aprendizagem da geração Y. Calidoscópio, v.9, n.1, p. 3-14, jan./abr. 2011. Disponível em: <http://revistas.unisinos.br/index.php/calidoscopio/article/viewFile/748/149>. Acesso em: 12 abr. 2015.

WARSCHAUER, Mark. Tecnologia e inclusão digital: a exclusão digital em debate. Tradução de Carlos Szlak. São Paulo: Senac, 2006. 319 p.

WILSON, Carolyn et al. Alfabetização midiática e informacional: currículo para formação de professores. Brasília, DF: Unesco, 2013. 194 p. Disponível em: <http://unesdoc.unesco.org/images/0022/002204/220418por.pdf>. Acesso em: 18 out. 2015.

ZABALA, Antoni. A prática educativa: como ensinar. Porto Alegre: Artmed, 2010. $224 \mathrm{p}$.

; ARNAU, Laia. Como aprender e ensinar competências. Porto Alegre: Artmed, 2010. 197 p.

ZIMMER, Josete Maria. Blog didático: integração na prática pedagógica. 2012. 155 f. Dissertação (Mestrado em Comunicação Educacional e Multimedia) - Universidade Aberta de Portugal, Lisboa, 2012. 
ANEXOS 
ANEXO A - Estrutura Curricular da Escola

Secretaria de Estado da Educaçăo
COORDENADORIA GERAL DE RECURSOS HUMANOS - CGRH
DIRETORIA DE ENSINO DA REGIÄO DE CARAPICUIBA
E. E. _ FERNANDO NOBRE
CIE: 010509

MATRIZ CURRICULAR - ESCOLA DE TEMPO INTEGRAL - 2015

Fundamento Legal: Lei Federal 9394/96, Resoluçăo SE 85 de 19/12/2013

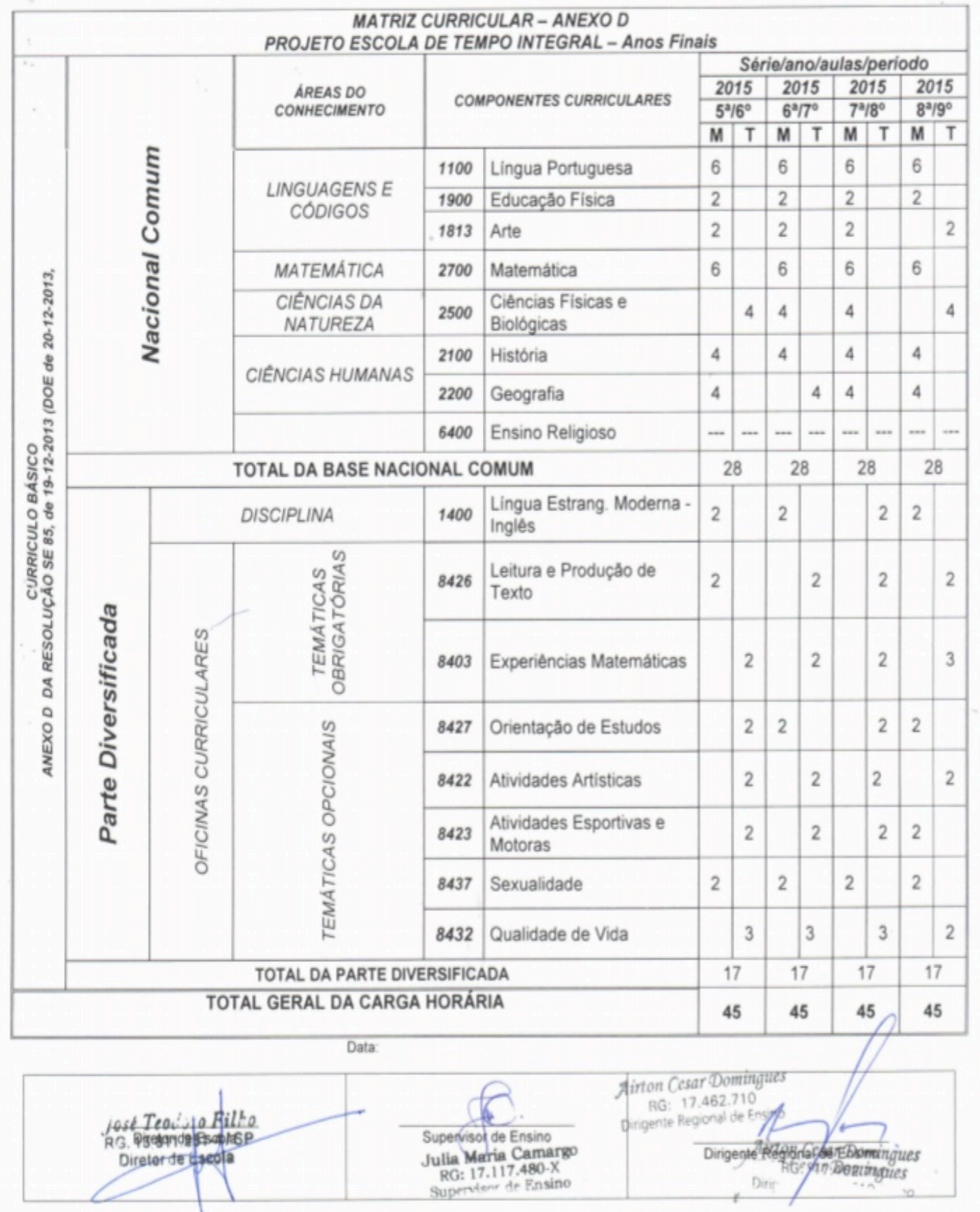

Documento digitalizado 


\section{ANEXO B - Modelo de Plano de Ensino do Professor}

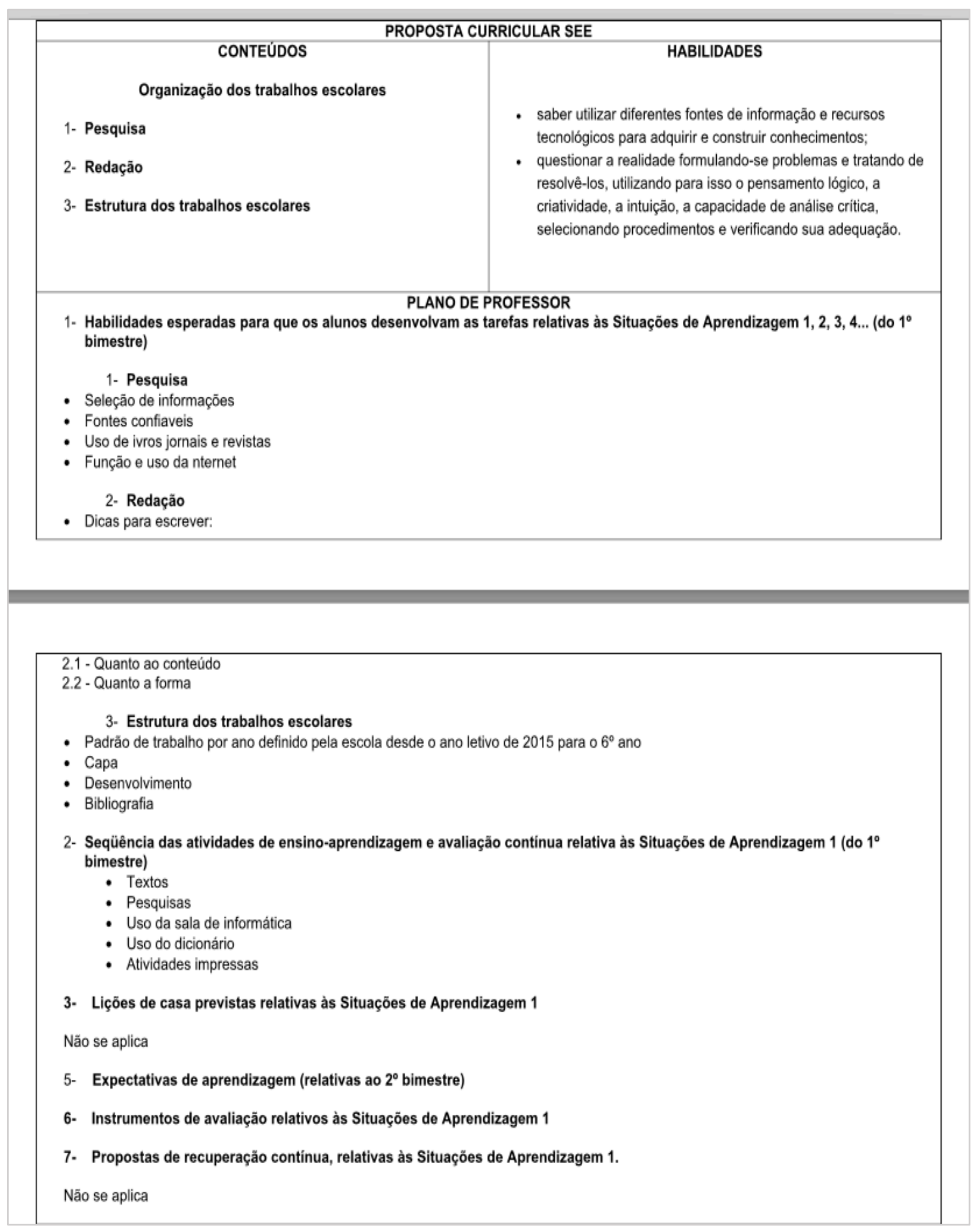

Documento digitalizado 


\section{APÊNDICES}




\section{APÊNDICE A - Produção acadêmica mapeada (2008-2017)}

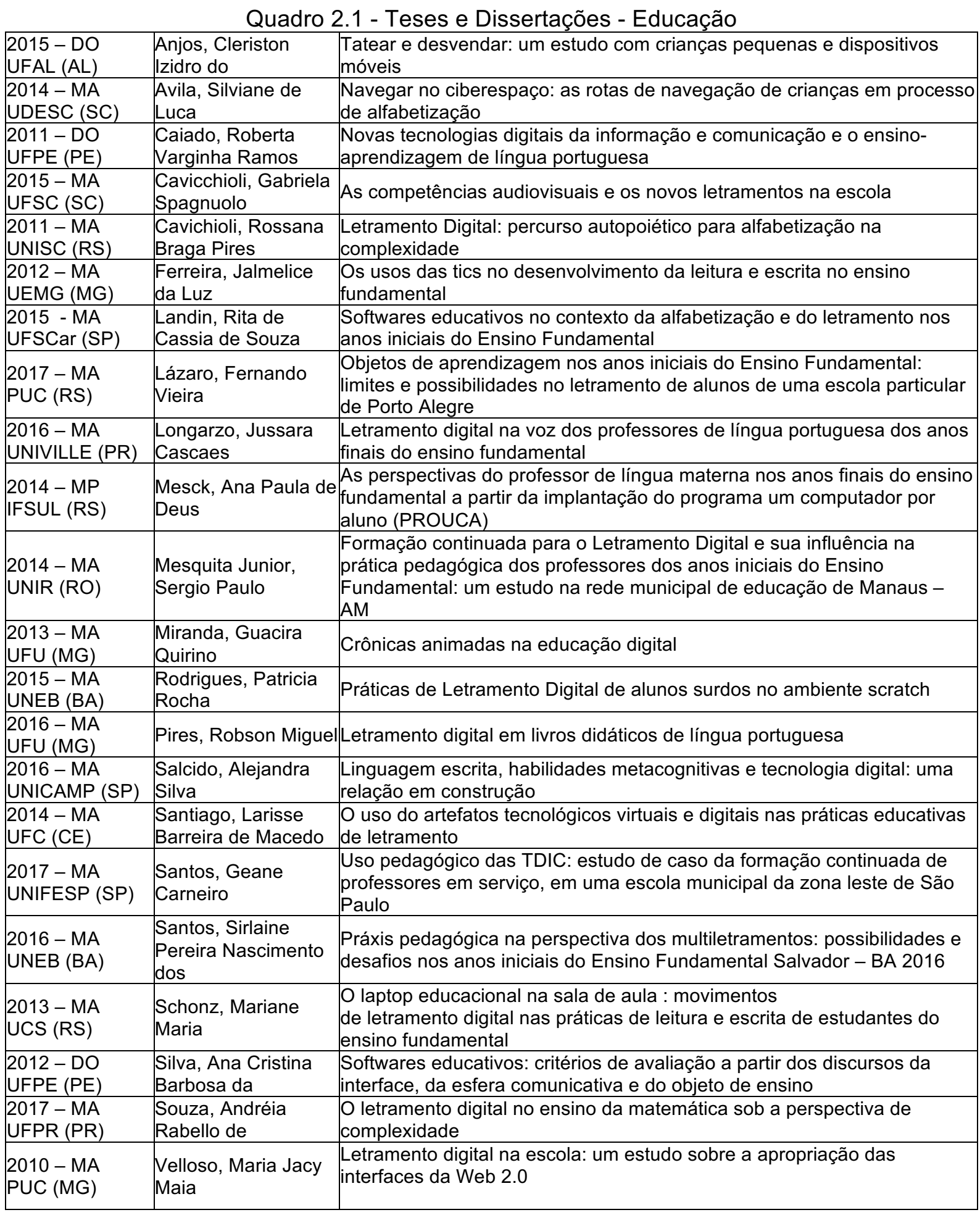


Quadro 2.2 - Teses e Dissertações - Linguística, Letras e Artes

\begin{tabular}{|c|c|c|}
\hline $\begin{array}{l}\text { Ano - Tipo } \\
\text { IES }\end{array}$ & Autor & Título \\
\hline $\begin{array}{l}2016-M P \\
\text { UEMS (MS) }\end{array}$ & $\begin{array}{l}\text { Almeida, Luciane } \\
\text { Ruis de Campos }\end{array}$ & $\begin{array}{l}\text { Letramento Digital: análise de propostas de atividades com gêneros } \\
\text { textuais em livro didático em língua portuguesa }\end{array}$ \\
\hline $\begin{array}{l}2015-\mathrm{MA} \\
\text { UNESP (SP) }\end{array}$ & $\begin{array}{l}\text { Almeida, Regiceli } \\
\text { Bento }\end{array}$ & Uma experiência de cibereducação para o Letramento Digital \\
\hline $\begin{array}{l}2016-M P \\
\text { UFPB (PB) }\end{array}$ & $\begin{array}{l}\text { Alves, Robson José } \\
\text { Gomes }\end{array}$ & A webquest como ferramenta de aprendizagem no contexto escolar \\
\hline $\begin{array}{l}2012-\text { MA } \\
\text { UNESP (SP) }\end{array}$ & $\begin{array}{l}\text { Arroyo, Raquel } \\
\text { Wohnrath }\end{array}$ & $\begin{array}{l}\text { Letramento Digital e letramento escolar: uma abordagem linguística da } \\
\text { prática de escrita em blogs }\end{array}$ \\
\hline $\begin{array}{l}2017-\mathrm{MA} \\
\text { UCPE (PE) }\end{array}$ & $\begin{array}{l}\text { Bezerra, Vera Lucy } \\
\text { Borba de Castro }\end{array}$ & $\begin{array}{l}\text { Leitura de gêneros discursivos/textuais digitais nos livros didáticos de } \\
\text { língua portuguesa: uma realidade? }\end{array}$ \\
\hline $\begin{array}{l}2014-\mathrm{MP} \\
\text { UFPB (PB) }\end{array}$ & $\begin{array}{l}\text { Correia, Elma } \\
\text { Silvanda Dantas }\end{array}$ & $\begin{array}{l}\text { Proinfo integrado e a formação continuada de professores do Ensino } \\
\text { Fundamental: uma realidade construída }\end{array}$ \\
\hline $\begin{array}{l}2014-\mathrm{MA} \\
\text { UNIFRAN (SP) }\end{array}$ & $\begin{array}{l}\text { Faleiros, Ana } \\
\text { Cristina dos Santos }\end{array}$ & $\begin{array}{l}\text { Letramento Digital na formação docente: produção de minicontos } \\
\text { multimodais }\end{array}$ \\
\hline $\begin{array}{l}2015-\mathrm{MP} \\
\text { UNESP (SP) }\end{array}$ & $\begin{array}{l}\text { Farizato, Regiceli } \\
\text { Bento de Almeida }\end{array}$ & Uma experiência de cibereducação para o Letramento Digital \\
\hline $\begin{array}{l}2017-\mathrm{MP} \\
\text { UFTM (MG) }\end{array}$ & $\begin{array}{l}\text { Feliciano, Claudia } \\
\text { Queluz Batista }\end{array}$ & Estratégias de leitura do gênero fábula em ambiente digital \\
\hline $\begin{array}{l}2009-\mathrm{DO} \\
\text { USP (SP) }\end{array}$ & $\begin{array}{l}\text { Fiorelli, Jaqueline de } \\
\text { Moraes }\end{array}$ & $\begin{array}{l}\text { Práticas de letramento na rede: ações discursivas, agência e o papel do } \\
\text { outro na construção da autoria }\end{array}$ \\
\hline $\begin{array}{l}2015-M P \\
\text { UFC (CE) }\end{array}$ & $\begin{array}{l}\text { Fontenele, Cristiane } \\
\text { de Mendonça }\end{array}$ & $\begin{array}{l}\text { Letramento Digital, práticas de leitura e escrita no ensino de língua } \\
\text { portuguesa do nono ano... }\end{array}$ \\
\hline $\begin{array}{l}2015-M P \\
\text { UFS (SE) }\end{array}$ & $\begin{array}{l}\text { Fontes, Ana Claudia } \\
\text { Silva }\end{array}$ & $\begin{array}{l}\text { Os multiletramentos na formação do leitor: o hipertexto numa releitura } \\
\text { crítica de textos da literatura sergipana }\end{array}$ \\
\hline $\begin{array}{l}2016-\text { MP } \\
\text { UNESP (SP) }\end{array}$ & $\begin{array}{l}\text { Fraga, Washington } \\
\text { Mateus }\end{array}$ & Letramento multissemiótico no Facebook: um novo desafio \\
\hline $\begin{array}{l}2015-\text { MP } \\
\text { UFBA (BA) }\end{array}$ & $\begin{array}{l}\text { Franco, Laylla } \\
\text { Gomes }\end{array}$ & $\begin{array}{l}\text { Letramento Digital: as aulas de língua portuguesa como construção da } \\
\text { autonomia do aluno }\end{array}$ \\
\hline $\begin{array}{l}2013-\text { MA } \\
\text { UNISINOS } \\
\text { (RS) }\end{array}$ & $\begin{array}{l}\text { Gomes, Raquel } \\
\text { Salcedo }\end{array}$ & $\begin{array}{l}\text { Textualidade sincrética em blogs produzidos por estudantes do Ensino } \\
\text { Fundamental }\end{array}$ \\
\hline $\begin{array}{l}2013-\text { MA } \\
\text { UFRN (RN) }\end{array}$ & Griner, Ana Priscila & $\begin{array}{l}\text { A linguagem do blog escolar em um trabalho com multiletramentos: } \\
\text { compartilhando sentidos }\end{array}$ \\
\hline $\begin{array}{l}2015-\mathrm{MP} \\
\text { UESC (BA) }\end{array}$ & $\begin{array}{l}\text { Guimaraes, Aline } \\
\text { Maria Ferreira dos } \\
\text { Santos. }\end{array}$ & $\begin{array}{l}\text { Os ficwriters e a escrita no suporte digital: a constituição do escritor/leitor } \\
\text { nas fanfics }\end{array}$ \\
\hline $\begin{array}{l}2010-M A \\
\text { UERJ (RJ) }\end{array}$ & $\begin{array}{l}\text { Lázaro, Rafael dos } \\
\text { Santos }\end{array}$ & $\begin{array}{l}\text { Leitura em meios virtuais: uma análise qualitativa do trabalho e desafios } \\
\text { docentes }\end{array}$ \\
\hline $\begin{array}{l}2016-\mathrm{MP} \\
\text { UFRN (RN) }\end{array}$ & $\begin{array}{l}\text { Leôncio, Maria } \\
\text { Almaiza de Medeiros }\end{array}$ & $\begin{array}{l}\text { Letramento Digital no Ensino Fundamental II: estratégias de leitura e } \\
\text { escrita com o uso do hipertexto }\end{array}$ \\
\hline $\begin{array}{l}2009-M A \\
\text { UERJ (RJ) }\end{array}$ & $\begin{array}{l}\text { Lima, Francis } \\
\text { Chagas }\end{array}$ & $\begin{array}{l}\text { Formando leitores na era digital: reflexões sobre a abordagem da leitura } \\
\text { no ensino de e/le através do mundo virtual }\end{array}$ \\
\hline
\end{tabular}




\begin{tabular}{|c|c|c|}
\hline $\begin{array}{l}\text { Ano - Tipo } \\
\text { IES }\end{array}$ & Autor & Título \\
\hline $\begin{array}{l}2009-M A \\
\text { UERJ (RJ) }\end{array}$ & $\begin{array}{l}\text { Lima, Francis } \\
\text { Chagas }\end{array}$ & $\begin{array}{l}\text { Formando leitores na era digital: reflexões sobre a abordagem da leitura } \\
\text { no ensino de e/le através do mundo virtual }\end{array}$ \\
\hline $\begin{array}{l}\text { 2015- DO } \\
\text { UFRJ (RJ) }\end{array}$ & $\begin{array}{l}\text { Lima, Simone da } \\
\text { Costa }\end{array}$ & $\begin{array}{l}\text { Parcerias digitais e a formação de professores de língua portuguesa: um } \\
\text { estudo à luz da teoria da atividade }\end{array}$ \\
\hline $\begin{array}{l}2015-\mathrm{MP} \\
\text { UFCG (PB) }\end{array}$ & $\begin{array}{l}\text { Lira, Evandro Alvares } \\
\text { de }\end{array}$ & $\begin{array}{l}\text { Sedes sociais: possibilidades mediadoras de produção de texto de } \\
\text { opinião no Ensino Fundamental }\end{array}$ \\
\hline $\begin{array}{l}2016-\mathrm{MA} \\
\text { UFMT (MT) }\end{array}$ & $\begin{array}{l}\text { Magedanz, Adelaide } \\
\text { Maria de Lima }\end{array}$ & Consumo e gênero: práticas de letramentos em vídeo-game \\
\hline $\begin{array}{l}2014-\text { MA } \\
\text { UNISINOS } \\
\text { (RS) }\end{array}$ & $\begin{array}{l}\text { Marques, Renata } \\
\text { Garcia }\end{array}$ & $\begin{array}{l}\text { Projeto didático de gênero como possibilidade para o ensino da língua } \\
\text { materna e o desenvolvimento das capacidades de linguagem de alunos } \\
\text { multirrepetentes }\end{array}$ \\
\hline $\begin{array}{l}2016-\mathrm{MP} \\
\text { UEPB (PB) }\end{array}$ & $\begin{array}{l}\text { Martins, Claudiane } \\
\text { Maciel da Rocha }\end{array}$ & $\begin{array}{l}\text { Gêneros digitais no livro didático de língua portuguesa: uma presença } \\
\text { possível }\end{array}$ \\
\hline $\begin{array}{l}2016-M A \\
\text { USP (SP) }\end{array}$ & $\begin{array}{l}\text { Mendonça, Helena } \\
\text { Andrade }\end{array}$ & $\begin{array}{l}\text { Letramentos digitais e formação educacional na educação básica: } \\
\text { investigação de práticas }\end{array}$ \\
\hline $\begin{array}{l}2016-\mathrm{MA} \\
\text { UNITAU (SP) }\end{array}$ & $\begin{array}{l}\text { Moraes, Luiz } \\
\text { Eduardo da Silva }\end{array}$ & $\begin{array}{l}\text { Textos que circulam na esfera digital presentes em livro didático de } \\
\text { língua portuguesa: uma questão de gênero }\end{array}$ \\
\hline $\begin{array}{l}2015-M A \\
\text { PUC (SP) }\end{array}$ & $\begin{array}{l}\text { Nascimento, Claudia } \\
\text { Rodrigues da Silva }\end{array}$ & $\begin{array}{l}\text { Escrita digital no Ensino Fundamental I: do livro didático à sequência } \\
\text { didática }\end{array}$ \\
\hline $\begin{array}{l}2014-\mathrm{MP} \\
\text { UFPB (PB) }\end{array}$ & $\begin{array}{l}\text { Oliveira, Flávia Sirino } \\
\text { de }\end{array}$ & Letramento Digital: a prática de leitura e de escrita mediada pelo blog \\
\hline $\begin{array}{l}2015-M P \\
\text { UFPB (PB) }\end{array}$ & $\begin{array}{l}\text { Pinheiro, Cínthia } \\
\text { Maria da Conceição } \\
\text { Bezerra }\end{array}$ & $\begin{array}{l}\text { Letramentos e produção textual: leitura e escrita de crônicas em } \\
\text { ambientes mediados ou não por computadores }\end{array}$ \\
\hline $\begin{array}{l}2015-\mathrm{MP} \\
\text { UFMG (MG) }\end{array}$ & $\begin{array}{l}\text { Prado, Michelle } \\
\text { Nogueira Lara }\end{array}$ & $\begin{array}{l}\text { Ensino da produção de texto escrito: livro didático e atividades } \\
\text { sistemáticas }\end{array}$ \\
\hline $\begin{array}{l}2015-\mathrm{MP} \\
\text { UFT (TO) }\end{array}$ & $\begin{array}{l}\text { Rodrigues, Erica de } \\
\text { Cassia Maia Ferreira }\end{array}$ & $\begin{array}{l}\text { Práticas de Letramento Digital na escola: o blog como estratégia de } \\
\text { ensino e formação de professores }\end{array}$ \\
\hline $\begin{array}{l}2013-\text { MA } \\
\text { UNISINOS } \\
\text { (RS) }\end{array}$ & $\begin{array}{l}\text { Rodrigues, Gisele } \\
\text { dos Santos }\end{array}$ & $\begin{array}{l}\text { O Letramento Digital do docente de língua materna e }(m) \text { suas } \\
\text { representações sobre práticas de linguagem: que eventos são } \\
\text { promovidos? }\end{array}$ \\
\hline $\begin{array}{l}2015-M P \\
\text { UERN (RN) }\end{array}$ & $\begin{array}{l}\text { Rodrigues, Paula } \\
\text { Veronica Ferreira }\end{array}$ & $\begin{array}{l}\text { Análise dos fatores de coerência nos textos de alunos do } 6^{\circ} \text { ano } \\
\text { veiculados via Facebook }\end{array}$ \\
\hline $\begin{array}{l}2016-\mathrm{MP} \\
\text { UFSC (SC) }\end{array}$ & $\begin{array}{l}\text { Rossarola, Lenir } \\
\text { Maria }\end{array}$ & Apropriação da webgrafia em pesquisa escolar \\
\hline $\begin{array}{l}2011-M A \\
\text { UFJF (MG) }\end{array}$ & $\begin{array}{l}\text { Saito, Fabiano } \\
\text { Santos }\end{array}$ & $\begin{array}{l}\text { (Multi)letramento(s) digital(is) na escola pública: reflexões sobre as } \\
\text { práticas discursivas de professoras que se relacionaram com as } \\
\text { tecnologias da informação e comunicação no ensino }\end{array}$ \\
\hline $\begin{array}{l}2015-M P \\
\text { UPE (PE) }\end{array}$ & $\begin{array}{l}\text { Santos, Carlos } \\
\text { Eduardo Barros dos }\end{array}$ & $\begin{array}{l}\text { A argumentação e o fórum de discussão virtual: uma questão de } \\
\text { letramento }\end{array}$ \\
\hline $\begin{array}{l}2014-\text { DO } \\
\text { UFBA (BA) }\end{array}$ & $\begin{array}{l}\text { Santos, Fernanda } \\
\text { Maria Almeida dos }\end{array}$ & $\begin{array}{l}\text { Práticas de Letramento Digital para crianças: fatores de diversidade e } \\
\text { possibilidades pedagógicas na aprendizagem do português escrito }\end{array}$ \\
\hline $\begin{array}{l}2015-\mathrm{MP} \\
\text { UEPB (PB) }\end{array}$ & $\begin{array}{l}\text { Santos, Jaqueline } \\
\text { Souza dos }\end{array}$ & $\begin{array}{l}\text { Inclusão de ambientes virtuais de aprendizagem nas práticas escolares } \\
\text { de língua portuguesa em Orobó/PE }\end{array}$ \\
\hline
\end{tabular}


Continuação

\begin{tabular}{|c|c|c|}
\hline $\begin{array}{l}\text { Ano - Tipo } \\
\text { IES }\end{array}$ & Autor & Título \\
\hline $\begin{array}{l}2015-M P \\
\text { UFPB (PB) }\end{array}$ & $\begin{array}{l}\text { Santos, Kelly } \\
\text { Cristine Martins dos } \\
\text { Santos }\end{array}$ & $\begin{array}{l}\text { O uso do blog como estratégia motivadora no processo de } \\
\text { (multi) Letramento Digital nas aulas de língua estrangeira moderna (lem) }\end{array}$ \\
\hline $\begin{array}{l}2015-\text { MP } \\
\text { UNIMONTES } \\
\text { (MG) }\end{array}$ & $\begin{array}{l}\text { Santos, Marta Ester } \\
\text { Brito }\end{array}$ & $\begin{array}{l}\text { Uso de tecnologias digitais na escola: implicações em desenvolvimento } \\
\text { de competências de leitura e escrita }\end{array}$ \\
\hline $\begin{array}{l}2015-M P \\
\text { UNIOESTE } \\
(P R)\end{array}$ & $\begin{array}{l}\text { Silva, Eliana } \\
\text { Aparecida da }\end{array}$ & $\begin{array}{l}\text { Narrativas digitais: contribuições à produção textual e ao Letramento } \\
\text { Digital no Ensino Fundamental }\end{array}$ \\
\hline $\begin{array}{l}2016-\text { MA } \\
\text { UNISINOS } \\
\text { (RS) }\end{array}$ & $\begin{array}{l}\text { Silva, Leandro } \\
\text { Coimbra da }\end{array}$ & $\begin{array}{l}\text { Reflexões sobre uma experiência com a produção de textos on-line: uma } \\
\text { análise das emoções expressas por alunos de Ensino Fundamental }\end{array}$ \\
\hline $\begin{array}{l}2015-M P \\
\text { UNIMONTES } \\
(\mathrm{MG})\end{array}$ & $\begin{array}{l}\text { Silva, Vanely } \\
\text { Cristiany Oliveira }\end{array}$ & $\begin{array}{l}\text { Multiletramentos: desenvolvimento de habilidades de produção e } \\
\text { recepção de textos em contextos digitais }\end{array}$ \\
\hline $\begin{array}{l}2016-M P \\
\text { UNIMONTES } \\
(\mathrm{MG})\end{array}$ & $\begin{array}{l}\text { Souza, Rosangela } \\
\text { Soares dos Santos }\end{array}$ & Gamificação: contribuições para a produção de textos narrativos \\
\hline $\begin{array}{l}2015-M P \\
\text { UNESP (SP) }\end{array}$ & $\begin{array}{l}\text { Souza, Rosenes } \\
\text { Luzia de }\end{array}$ & $\begin{array}{l}\text { Repositórios de objetos de aprendizagem de língua portuguesa no Ensino } \\
\text { Fundamental: alternativas para professores }\end{array}$ \\
\hline $\begin{array}{l}2016-M P \\
\text { UEL (PR) }\end{array}$ & $\begin{array}{l}\text { Valadão, Fernada } \\
\text { Izidório }\end{array}$ & $\begin{array}{l}\text { Facebook: espaço de interação e aprendizagem colaborativa no processo } \\
\text { de construção da língua materna e do Letramento Digital }\end{array}$ \\
\hline $\begin{array}{l}2015-\text { MP } \\
\text { UESC (BA) }\end{array}$ & $\begin{array}{l}\text { Varjao, Cassia } \\
\text { Goretti Oliveira }\end{array}$ & $\begin{array}{l}\text { O suporte digital para a construção de sequências argumentativas: uma } \\
\text { estratégia de ensino para o } 9^{\circ} \text { ano }\end{array}$ \\
\hline $\begin{array}{l}2010-\text { MA } \\
\text { UNISINOS } \\
\text { (RS) }\end{array}$ & $\begin{array}{l}\text { Zart, Lídia Helena } \\
\text { Muller }\end{array}$ & $\begin{array}{l}\text { A escrita emergente: autoria nas produções textuais escolares em } \\
\text { ambientes digitais, com o uso da Internet }\end{array}$ \\
\hline
\end{tabular}


Quadro 2.3 - Teses e Dissertações - Outras áreas

\begin{tabular}{|c|c|c|}
\hline $\begin{array}{l}\text { Ano - Tipo } \\
\text { IES }\end{array}$ & Autor & Título \\
\hline $\begin{array}{l}2017-\mathrm{MP} \\
\text { UECE (CE) }\end{array}$ & $\begin{array}{l}\text { Ribeiro, Marcia } \\
\text { Maria }\end{array}$ & $\begin{array}{l}\text { Projeto sapeca: processo dirigido de alfabetização e análise da aplicação } \\
\text { discente e docente em uma escola pública }\end{array}$ \\
\hline $\begin{array}{l}2016-M P \\
\text { PUC (MG) }\end{array}$ & Rocha, Marina Silva & $\begin{array}{l}\text { Entendendo o sistema cardiovascular: uma sequência didática que utiliza } \\
\text { o netbook como recurso educacional no ensino de ciências' }\end{array}$ \\
\hline $\begin{array}{l}2016-\text { MP } \\
\text { UEPB (PB) }\end{array}$ & $\begin{array}{l}\text { Santos, Edilene } \\
\text { Araújo dos }\end{array}$ & $\begin{array}{l}\text { Práticas de Letramento Digital nas escolas municipais de Ensino } \\
\text { Fundamental de Patos-PB }\end{array}$ \\
\hline $\begin{array}{l}2015-\mathrm{MP} \\
\text { UEPB (PB) }\end{array}$ & $\begin{array}{l}\text { Nascimento, lara } \\
\text { Costa }\end{array}$ & $\begin{array}{l}\text { O software publisher como ferramenta pedagógica: uma proposta para } \\
\text { viabilização do Letramento Digital }\end{array}$ \\
\hline $\begin{array}{l}2015-\text { MA } \\
\text { UNAMA (PA) }\end{array}$ & $\begin{array}{l}\text { Brigida, Fabricio } \\
\text { Borges Santa }\end{array}$ & $\begin{array}{l}\text { A escola tradicional no mundo digital: uma análise da prática de } \\
\text { Letramento Digital na contemporaneidade em uma escola em Belém do } \\
\text { Pará }\end{array}$ \\
\hline $\begin{array}{l}2015-\text { MA } \\
\text { UFSCar (SP) }\end{array}$ & $\begin{array}{l}\text { Falcão, Patrícia } \\
\text { Mirella de Paulo }\end{array}$ & $\begin{array}{l}\text { Estudo sobre as tecnologias digitais de informação e comunicação como } \\
\text { mediadoras da construção do conhecimento na percepção de professores } \\
\text { em formação e de crianças do Ensino Fundamental }\end{array}$ \\
\hline $\begin{array}{l}2014-\text { MP } \\
\text { UFRPE (PE) }\end{array}$ & $\begin{array}{l}\text { Marques, Roberta } \\
\text { Goncalves Gomes }\end{array}$ & $\begin{array}{l}\text { Letramento Digital na ciberinfância: diálogos com práticas pedagógicas no } \\
\text { Ensino Fundamental }\end{array}$ \\
\hline $\begin{array}{l}2014-\mathrm{MP} \\
\text { UEPB (PB) }\end{array}$ & $\begin{array}{l}\text { Silva, Antonio } \\
\text { Gregorio da }\end{array}$ & Ensino de geografia na era digital: uma experiência em sala de aula \\
\hline $\begin{array}{l}2013-\text { MA } \\
\text { UNIGRANRIO( } \\
\text { RS) }\end{array}$ & $\begin{array}{l}\text { Santos, Margareth } \\
\text { Maura dos }\end{array}$ & $\begin{array}{l}\text { Gênero digital - o blog no contexto escolar: uma proposta pedagógica } \\
\text { para a promoção de Letramento Digital }\end{array}$ \\
\hline
\end{tabular}




\section{APÊNDICE B - Diários de campo}

\begin{tabular}{|c|c|c|}
\hline Diário de campo n. 4 & Organização dos trabalhos nas Oficinas & $\begin{array}{l}\text { 2a. Semana } \\
\text { maio/2016 }\end{array}$ \\
\hline Fase & \multicolumn{2}{|c|}{ Sondagem diagnóstica - Observação nas Oficinas de Orientação de Estudos - OOE } \\
\hline Foco & \multicolumn{2}{|l|}{ A Oficina e organização dos trabalhos escolares } \\
\hline Questão guia & \multicolumn{2}{|l|}{ Como os trabalhos da OOE estão planejados? } \\
\hline Participantes & \multicolumn{2}{|l|}{ 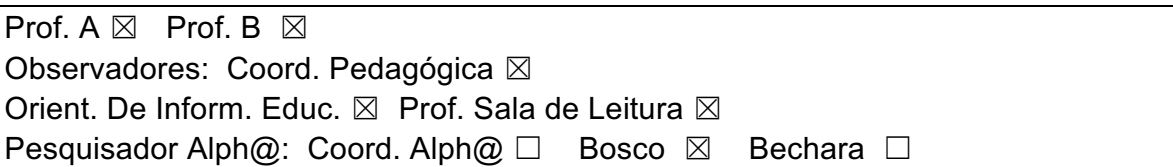 } \\
\hline
\end{tabular}

\section{Contexto observado}

Orientação e avaliação de trabalhos escolares em 2016.

Em 2016, a Profa. Noemi foi remanejada para a Oficina de Experiências Matemáticas e o Prof. B foi remanejado da Oficina Qualidade de vida para a Oficina Orientação de Estudos e o Prof. A continuou na OOE.

Temas da OOE:

Primeiro semestre - Relacionamento na sala de aula, Organização para os estudos.

Segundo semestre - Hábitos e rotinas de estudo; hábitos para a criação de uma rotina de estudos e os temas: construção da identidade, para o $6^{\circ}$ ano e projeto de vida pessoal e profissional para as demais turmas.

Os alunos farão um projeto sobre profissões, com busca na Web e entrevistas com profissionais de várias áreas. Eles irão escolher quem entrevistar. Os trabalhos serão individuais, com apresentação nas turmas.

Produtos dos alunos: Trabalhos de pesquisa manuscritos e encadernados, com desenhos ou colagem.

\section{Manifestação dos participantes}

O Prof. A falou que na sondagem que realizou com a turma ingressante na Escola foi identificado que os alunos tinham necessidades escolares básicas, como usar o caderno de anotações e a régua, também "eles não compreendem o horário, não sabem organizar seus livros e o material para cumprimento do horário escolar [...] Vou trabalhar a parte de organização, porque esse deve ser o nosso ponto de partida", ressaltou Prof. A.

A Coordenadora pedagógica, reforçou: "[...] A professora das Oficinas de Orientação de Estudos começou da base com o $6^{\circ}$ ano, desde a organização do caderno, pois eles não sabem, eles precisam dessa base para se organizar a estudar, a pesquisar..."

\section{Observação da pesquisadora}

Bem... Esta semana foi muito boa! Eu observei tantas coisas que só estando na escola poderia perceber... - Observei que em 2016 as orientações para elaboração dos trabalhos escolares foram retiradas das paredes das salas. Mas, não foi possível se saber exatamente o motivo. Agora, os professores apresentam a organização para os trabalhos no quadro de giz e os alunos copiam nos seus cadernos. Eu tirei foto do quadro!!!

- O planejamento na OOE está sendo feito individualmente, e no HTPC, os professores, na medida do tempo possível, compartilhavam algumas de suas ideias.

- Percebi que o termo 'planejamento' está desgastado no contexto escolar. Os professores copiam os planos de um ano para outro, sem mesmo conhecer os alunos; reprisam as anotações de cadernos de alunos de uma turma para outra.

- É preciso dar sentido às TDIC na prática educativa (em todas as ações docentes).

Dar atenção à interação do professor com seus alunos, e trabalhar de modo integrado, referenciada no Letramento Digital (em todos os seus desdobramentos), e consequentemente os alunos podem fazer uso da leitura e construir seus textos e hipertextos e o professor passa a ter novas formas de ensinar e avaliar. Desenvolver competências docentes (mapear, narrar, tecer e mediar???) e as habilidades discentes, quais seriam, com as TDIC?

- Isso requer estar bem atenta à realidade, ouvir mais os participantes e agir com coerência e respeito ao planejamento dos professores, mas buscando estratégias alternativas.

- O uso de TDIC na OOE tem sido limitado (Internet para as pesquisas livres e vídeos no Youtube).

- Acho que informações sobre como pesquisar na Web, com base no Letramento Informacional vai ajudar todos.

- Os professores receiam trabalhar com as TDIC por queda de energia e de Internet, disponibilidade do Laboratório, e condições de uso (tem uns com problema), falta equipamentos e móveis suficientes e Wi-Fi.

- Será um desafio pra pesquisa, mas vamos discutir com os professores, alunos e observadores no Grupo Focal para encontrarmos uma estratégia juntos... Eu tenho umas ideias, mas o bom será pensar junto, assim com o envolvimento e participação, com certeza o engajamento vai ser muito bom...

- Será que as referências do Letramento Digital podem trazer contribuições para mudar o sentido destas práticas? 


\begin{tabular}{|c|c|}
\hline Diário de campo n. 7 & $\begin{array}{l}\text { 4a. Semana } \\
\text { maio/2016 }\end{array}$ \\
\hline Fase & $\begin{array}{l}\text { Sondagem diagnóstica - Análise sobre a Plataforma Moodle } \\
\text { Centro Virtual de Formação Permanente (CVFP) e demais mídias }\end{array}$ \\
\hline Foco & Plataforma Moodle criada pelo Alpha \\
\hline Questão guia & $\begin{array}{l}\text { Como se dá o uso de TDIC no contexto escolar? Existe uma cultura digital? Há } \\
\text { formação docente sobre o uso das TDIC? }\end{array}$ \\
\hline Participantes & 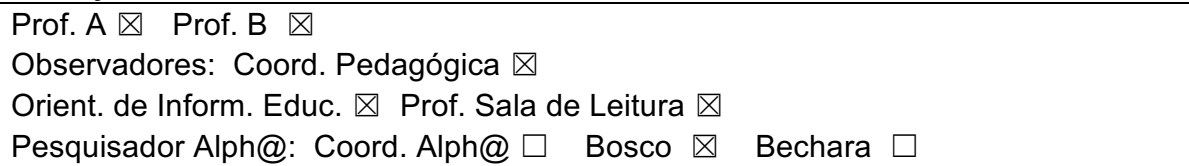 \\
\hline
\end{tabular}

\section{Contexto observado}

- A Escola Fernando Nobre tem "certa" cultura digital... Eles têm 4 blogs que foram tentativas da Orient. de Inform. Educ, a profa. Josete, mas é ela que faz as postagens e atualizações em um deles. Não tem muito acesso por parte dos professores e alunos. 1) E.E. Fernando Nobre (2008) - atividades escolares gerais, 2 posts; 2) Blog Oficina Nobre (2009) - atividades e projetos das oficinas curriculares, 160 postagens; 3) Blog Jornal Fernando Nobre (2014), 2 postagens. O professor solicitante e responsável a dar continuidade a esse blog saiu da Escola em 2015, não teve continuidade (informou a Profa. Josete). 4) Blog para atividades da Sala de Leitura (2013), 6 postagens. Tem uma conta no Facebook (2012), com atualizações constantes; 544 seguidores, entre professores, alunos, funcionários e amigos da Escola. Canal YouTube (2013) - 7 vídeos de palestras. Google+ (2013), 8 postagens; canal YouTube e 1 álbum de fotos de atividades festivas na Escola.

- No caso da formação docente para uso das TDIC foi criado é um ambiente virtual na Plataforma Moodle, administrada pelo departamento: Curso de Extensão da Universidade de São Paulo (STOA/USP). Foi criado em 2015 pela Coord. do Alph@ formação e interação de monitores, corpo docente, pedagógico e gestor da Escola e pesquisadores do Grupo Alph@ e para também servir de apoio às nossas pesquisas acadêmicas. O objetivo era atender e melhorar a comunicação interna, pois os professores não se encontram no HTPC. Vários deles trabalham em outras escolas... Muitos não possuem condições de estarem juntos na Fernando Nobre e nem nos HTPC previstas no cronograma da Direção.

\section{Descrição do Moodle - CVFP}

- O CVFP é organizado em tópicos, o primeiro destinado à ambientação no ambiente, com as boas vindas pela Coordenadora do Alph@, fórum de apresentação, fórum de notícias, tutorial do Moodle, normas de convivência, arquivo com material apresentado nas palestras do Alph@ etc.; o segundo tópico é direcionado à construção do Projeto Alph@, com abertura de fóruns de discussão nas temáticas - gestão compartilhada e habilidades; planejamento escolar; leituras diversas de interesse educacional, agenda, imagens e frequência de reuniões; o terceiro tópico é destinado aos componentes curriculares (oficinas e disciplinas). Estão disponíveis orientações para o trabalho com projetos e para o uso de TDIC nos estudos e pesquisas escolares, tais como: Parâmetros Curriculares Nacionais da sua área de conhecimento, orientações da SE/SP e conteúdos recomendados por membros do Alph@, inclusive aqueles produzidos nesta pesquisa.

- São oportunizadas as interações entre professores da Escola e os pesquisadores do Alph@ nos fóruns Fórum de Acompanhamento dos projetos criado para acompanhar as atividades das oficinas com postagem de projetos, portfólios, relatórios etc.; e no Fórum Roda conversa da Oficina para ser mais um espaço para esclarecimento de dúvidas, orientações específicas, marcação de encontros etc.

- No primeiro ano do CVFP verificou-se participação de 32 usuários no CVFP: o número de agentes da Escola que visualizaram arquivos e links indicados para leitura variou de dois a sete em cada item postado no ambiente. - Quanto à participação nos fóruns, o de apresentações, visualizados por 30 usuários contou com mensagem de 6 agentes da Escola. Os membros do Alph@ fizeram suas apresentações e os que realizaram suas pesquisas na Fernando Nobre abriram questões em fóruns específicos. O fórum que discutiu habilidades, visualizado por 18 usuários, obteve mensagem de 8 agentes da Escola. O fórum sobre gestão foi visualizado por 21 usuários, mas não houve comentários. No Fórum - Roda de conversas das oficinas, 11 usuários visualizaram, mas houve apenas 4 mensagens, 2 delas do Prof. B. No Fórum de Acompanhamento dos projetos tiveram acesso 16 usuários e 3 comentaram, inclusive do Prof. A, que anexou o portfólio de 2015.

\section{Manifestação dos participantes}

- A Coordenadora pedagógica revelou a dificuldade que encontravam para a postagem de documentos no Moodle, ela afirmou que "Eles não conseguem publicar lá, entrar, publicar, é complicado; esquecem a senha e manifestam dificuldade para o acesso"

- Os professores também manifestaram dificuldade para o acesso: o Prof. A disse: "Eu não consegui entrar no Moodle, esqueci a senha. Professora...eu não tenho mais computador em casa. Também não consigo acessar pelo meu celular...no ônibus voltando para casa! Não tenho Internet boa."

- O Prof. B - "Eu uso o celular pré-pago ... Não tenho internet e nem wifi. Meu celular é apenas para contato com os familiares... Eu sei que podemos entrar no Moodle pelo celular... A USP fez isto para nós... Mas é ruim ler as coisas e postar numa tela tão pequena". 
Continuação

- A Coordenadora pedagógica é professora de História, tem certa liderança e foi escolhida para atender as funções de coordenação dos professores e até de orientação educacional de alunos e familiares. Ela se expressou sobre o Moodle; "eu acho muito importante ter um ambiente, inclusive com aquele espaço dedicado às comunicações da direção para os professores... Mas, não sei se isto intimida os professores nas postagens que gostariam de fazer ou se acredito nas dificuldades que eles dizem, como não ter tempo; os HTPC são espaços de preenchimento de formulários para a Secretaria; correção de provas; colocar os problemas da escola e da indisciplina de alguns alunos... Enfim, acho muito pertinente, mas a gente tem todos estes desafios..."

\section{Minhas Reflexões}

- As oportunidades de formação presencial são limitadas pelo tempo disponível nos HTPC. As que pude participar constatam toda a complexidade de formação docente (acho que muito reduzida)... Não há troca de experiências pedagógicas. Muitos aproveitam para corrigir provas, se alimentar. Preencher diários de classe e reclamar da indisciplina dos alunos. O Laboratório é usado para preencher a falta de sala para atender o número de alunos e turmas existentes para que a escola seja de tempo integral.

- O Moodle foi apresentado ao corpo docente em palestras durante os HTPC e atendimentos individuais pelos pesquisadores do Alph@, mas a dificuldade de acesso, motivada pela impossibilidade de usar os computadores do laboratório, pelo celular deles que são usados apenas socialmente e pela falta de tempo para estudos, leituras e compartilhamento de aulas bem sucedidas, projetos, produções dos alunos etc.

- Com a mudança anual no quadro de professores nas escolas estaduais há alterações dos inscritos no CVFP constantemente, implica em desafios e descontinuidade do processo de formação docente nesse ambiente.

- A participação dos agentes da Escola não foi o desejável por todos, mas sinalizou, uma ambientação nessa Plataforma e a necessidade de continuidade do processo de formação de professores, pois poucos permanecem na Escola e outros chegam a cada ano, o que aponta para uma formação contínua, em caráter singular.

- A profa. Josete afirmou que esta sala é subutilizada; está sempre ocupada com aulas regulares ... Os professores por falta de manutenção raramente usam os computadores ... Não há espaço adequado ... É um computador para pelo 2 - 3 alunos... Os computadores não têm som... O retroprojetor não tem lâmpada... Os alunos quando se inscrevem para usar a sala, para fazer as pesquisas das tarefas escolares, usam o espaço como uma Lan House... Isto é, ficam jogando, acessando sites de artistas, postando nas redes sociais... Absolutamente dispersos e sem projeto de orientação de estudos...

- Estou impressionada quando leio os outros diários de campo que fiz... Estou conseguindo compreender porque o Letramento Digital e a sua cultura é tão difícil de ser implementada. O tempo, o saber o que fazer, a existência de um projeto orientador parece ser uma alternativa estratégica que poderá ajudar.

Acho que terei que ouvir mais os professores e alunos em conversas informais, nos corredores, nas oficinas nos HTPC e fazer reunião de Grupo Focal.

- Acho importante aproveitar o que existe de infraestrutura na escola. Não dá para contar com os aplicativos e recursos tecnológicos que tenho visto pela revisão de estudos que tenho feito. Acho que partir do que existe, e fortalecer o que eles já possuem pode ser uma boa estratégia.

- O Moodle vai demorar para ser habitual na escola, pelas dificuldades observadas; queda de energia; falta de segurança; computadores insuficientes.. E falta de tempo pra nós sentarmos com cada um dos professores da escola. Não tem tempo suficiente nos HTPC, e durante a semana, o Laboratório está sempre sendo usado com aulas (às vezes sem usar o computadores)

- Os professores não têm reserva para usar a tecnologia. Eles desejam com ansiedade. Mas parece que têm medo. O Prof. B me disse isso. Porque não sabe usar, tem medo.

- Gostariam que os blogs já criados fossem mais usados. Acho que preciso começar com ações planejadas com eles a partir dos recursos tecnológicos ou aplicativos que eles já conhecem e dominam. Preciso mapear também as necessidades e demandas dos professores que acabam ficando perdidos porque as oficinas não têm "conteúdos específicos"...

- Ficou claro que professores e alunos querem as mídias, sentem-se desafiados.

- Será que isto é relevante para eles? Estou estabelecendo relações com o Letramento e ninguém comenta sobre os usos das tecnologias que eles conhecem para uso pedagógico. Mas as conversas com os alunos demonstraram que eles gostam de blog, acessam uns dos outros e usam muito o celular para acessar a Web... Acho que terei dois trabalhos: um será usar as tecnologias com os professores a partir dos PowerPoints que eles fazem e depois avançar em questões de Letramento informacional para que possam orientar seus alunos.

- Nossa! Os diários têm sido um procedimento e técnica que tem me permitido, com os registros e narrativas, pensar ações inovadoras para as práticas dos professores (é importante mapear relevâncias) e para fazer outras relações que me levarão, com certeza, compreender que não vou conseguir resolver as dificuldades observadas; mas, formar os professores para planejamento que incorpore as TDIC... eis meu desafio. Elas são importantes, porque os alunos conhecem muitas ... E os professores conhecem menos e precisam usar. 


\begin{tabular}{|c|c|}
\hline Diário de campo n. 28 & O Design pedagógico com TDIC \\
\hline Fase & $\begin{array}{l}\text { Implementação da Ação } \\
\text { Acompanhamento presencial em atividades docentes de planejamento }\end{array}$ \\
\hline Foco & Planejamento da Feira Cultural 2016 com uso de TDIC \\
\hline Questão guia & Como tecer relações entre o planejamento escolar e o uso das TDIC? \\
\hline Participantes & $\begin{array}{l}\text { Prof. A } \otimes \text { Prof. } B \otimes \\
\text { Observadores: Coord. Pedagógica } \otimes \\
\text { Orient. de Inform. Educ. } \otimes \text { Prof. Sala de Leitura } \otimes \\
\text { Pesquisador Alph@: Coord. Alph@ } \square \quad \text { Bosco } \square \text { Bechara } \square\end{array}$ \\
\hline
\end{tabular}

\begin{tabular}{|c|c|c|c|c|}
\hline Contexto & \multicolumn{4}{|c|}{$\begin{array}{l}\text { Reunião com os professores, após o primeiro HTPC. A Coordenadora Pedagógica foi chamada } \\
\text { pelo Prof. B, a fim de dar seu parecer quanto à possibilidade de utilização do Laboratório de } \\
\text { Informática no dia da Feira Cultural. }\end{array}$} \\
\hline \multicolumn{2}{|c|}{ Ação da Pesquisadora } & $\begin{array}{l}\text { Observação da } \\
\text { Pesquisadora }\end{array}$ & Manifestação dos participantes & $\begin{array}{l}\text { Observação pós } \\
\text { planejamento }\end{array}$ \\
\hline \multicolumn{2}{|c|}{$\begin{array}{l}\text { No primeiro momento sugeri } \\
\text { apresentação dos trabalhos } \\
\text { dos alunos OOE em diversas } \\
\text { mídias na Feira, dando } \\
\text { exemplos práticos de como } \\
\text { fazer a partir do que eles } \\
\text { tinham realizado durante o } \\
\text { semestre. }\end{array}$} & $\begin{array}{l}\text { Os Profs. A e B } \\
\text { expressaram interesse em } \\
\text { usar TDIC e a necessidade } \\
\text { de apoio técnico e } \\
\text { pedagógico. } \\
\text { Mas, tiveram receio em não } \\
\text { poder usar o Laboratório de } \\
\text { Informática na Feira. }\end{array}$ & $\begin{array}{l}\text { "Mas e aí, como que eu vou } \\
\text { apresentar isso na Feira? Isso que é } \\
\text { a questão." Prof. A } \\
\text { "Se você me ajudar a construir } \\
\text { isso... Acho que a gente consegue } \\
\text { conciliar." Prof. A } \\
\text { "Podemos fazer vídeos [pausa] ia } \\
\text { ficar muito legal." } \\
\text { Prof. B }\end{array}$ & \multirow{3}{*}{$\begin{array}{l}\text { Os Profs. A e B não } \\
\text { conseguiram construir } \\
\text { os vídeos sozinhos. } \\
\text { Organizaram uma } \\
\text { exposição de trabalhos } \\
\text { em varal dos } \\
\text { desenhos, projetos e } \\
\text { redações dos alunos } \\
\text { por receio em não } \\
\text { apresentar algo físico à } \\
\text { SE e de não funcionar } \\
\text { a Internet } \\
\text { Planejaram dar } \\
\text { assistência aos alunos } \\
\text { no Laboratório de } \\
\text { Informática no dia da } \\
\text { Feira em momentos } \\
\text { alternados porque } \\
\text { estariam também em } \\
\text { outra sala. } \\
\text { Os vídeos foram } \\
\text { produzidos com apoio } \\
\text { de recurso didático } \\
\text { (tutorial), com as } \\
\text { imagens de atividades } \\
\text { com os alunos com uso } \\
\text { de TDIC. }\end{array}$} \\
\hline \multicolumn{2}{|c|}{$\begin{array}{l}\text { Argumentei sobre o trabalho } \\
\text { da OOE em } 2016 \text { com uso } \\
\text { de TDIC, devendo ser } \\
\text { compartilhado com a } \\
\text { comunidade escolar na Feira. }\end{array}$} & $\begin{array}{l}\text { Prof. A revelou medo e } \\
\text { insegurança com a estrutura } \\
\text { tecnológica e em sua } \\
\text { própria condição de uso do } \\
\text { equipamento. }\end{array}$ & $\begin{array}{l}\text { "Eu até entendo, mas fico com } \\
\text { medo de não funcionar esse } \\
\text { negócio." Prof. A } \\
\text { "[...]Meu medo é não funcionar no } \\
\text { dia da Feira, porque pode cair a } \\
\text { internet[...]Âs vezes quando tem } \\
\text { muita coisa ligada, não funciona, a } \\
\text { internet cai" Prof. A } \\
\text { "E se eu não conseguir acessar?" } \\
\text { Prof. A }\end{array}$ & \\
\hline \multicolumn{2}{|c|}{$\begin{array}{l}\text { Orientei os professores a } \\
\text { construírem narrativas } \\
\text { digitais com a construção de } \\
\text { vídeos a partir de desenhos } \\
\text { e redações dos alunos com o } \\
\text { App Animoto. }\end{array}$} & $\begin{array}{l}\text { Prof. A e o Prof. B } \\
\text { manifestaram maior } \\
\text { interesse em apresentação } \\
\text { dos trabalhos com uso de } \\
\text { papel sulfite e cartolinas. }\end{array}$ & $\begin{array}{l}\text { "Tem que ter alguma coisa física." } \\
\text { Prof. A } \\
\text { "Estava pensando em fazer no } \\
\text { papel mesmo e pendurar lá..." } \\
\text { Prof. A } \\
\text { "Vamos separar as fotos e na } \\
\text { próxima semana a gente senta pra } \\
\text { fazer, você nos ajuda?" Prof. A }\end{array}$ & \\
\hline
\end{tabular}

Fonte: a autora (2016)

\section{Minhas Reflexões:}

- Respeitar o planejamento existente no Plano escolar é condição para estimular alternativas estratégicas para um design pedagógico articulado com as TDIC, e que precisa ter sentido e ser adequado quanto aos seus objetivos e finalidades. Isso é fundamental, respeitar o tempo e o espaço da escola.

- Os professores cumprem determinações da Secretaria da Educação. Apresentar trabalhos para a Feira Cultural é um exemplo disso... Eles receiam que possam ser criticados... o Prof. B é contratado no Estado.

Tem muita coisa a ser mostrada na Feira. Acho que uma alternativa será envolver um grupo de alunos ... Quem sabe fazer uma Mostra com o Blog da Oficina, dos alunos...

- Mas, não tem ninguém quem avalie as experiências de sucesso; mas há espaço de compartilhamento para isto. O Moodle é um espaço. Vou incentivar os professores a fazer seus portfólios de postar no CVFP, no Blog 


\section{APÊNDICE C - Guia para Pesquisa Documental}

\section{Material para a Pesquisa Documental}

Fase: Diagnóstico, Implementação da Ação e Avaliação

- Documentos da Secretaria de Educação do Estado de São Paulo

- Legislação brasileira e paulista específicas ao estudo

- Documentos escolares: cadernos de referências, projetos, planos, imagens do cotidiano e produções nas Oficinas de Orientação de Estudos

- TDIC pré-existentes na escola

- TDIC usadas na pesquisa: Google Drive, Blog, Facebook, WhatsApp, Moodle

- Reportagens sobre a escola

\section{Questões orientadoras}

1. O que orienta os documentos oficiais para a escola e para a Oficina de Orientação de Estudos em $2016 ?$

2. Como se apresentou o uso das TDIC no período da pesquisa nos documentos escolares? 


\section{APÊNDICE D - Guia para Observação Participante}

\section{Questões orientadoras}

\section{Fase: Diagnóstico e Implementação da Ação e Avaliação}

1. Como se apresentou o uso das TDIC no período da Pesquisa?

2. Como se apresentaram as ações dos professores e alunos com TDIC nas Oficinas de Orientação de Estudos no período da Pesquisa?

\section{Fase: Implementação da Ação e Avaliação}

1. Que resultados foram obtidos com a Pesquisa?

2. Que fatores favoreceram o fortalecimento das ações docentes/discentes no desenvolvimento da cultura digital, sob a perspectiva do Letramento Digital?

3. Que fatores dificultaram o fortalecimento das ações docentes/discentes no desenvolvimento da cultura digital, sob a perspectiva do Letramento Digital? 


\section{APÊNDICE E - Questionário A - Sondagem diagnóstica com professores}

\section{(Adaptação do Inventário de Pesquisa do Grupo Alph@ 2015)}

Prezado (a) professor (a),

Com o objetivo de conhecer sua aproximação com as Tecnologias Digitais de Informação e Comunicação, gostaria que respondesse as questões abaixo.

Obrigada,

Profa. Fátima Rios, doutoranda Faculdade de Educação da USP

\section{Parte 1 - Identificação}

Nome (opcional):

Trabalhou na Escola Estadual Fernando Nobre no ano anterior? SIM $\square$ NÃO

Se respondeu SIM na pergunta anterior, há quanto tempo trabalha na Escola?

Sexo: $\mathrm{F} \square \mathrm{M} \square$. Idade:

Disciplina/Oficina (s) em que atua:

Ano: $6 \square 7 \square 8 \square 9 \square$ Número de alunos: Número de turmas:

Quanto tempo na função docente?

Outra função na Escola? Qual?

Graduação: Pós graduação:

\section{Parte 2 - Inventário de Fluência Digital}

Em relação às tecnologias digitais abaixo, marque com um "X" a opção que indica seu caso

\begin{tabular}{l|ll}
\multicolumn{1}{c}{ Pergunta } & \multicolumn{2}{c}{ Sua resposta } \\
\hline Tem e-mail? & $\square$ não & $\square$ sim, qual? \\
\hline Tem celular? & $\square$ não & $\square$ sim \\
\hline Tem computador ou laptop em casa? & $\square$ não & $\square$ sim \\
\hline Tem tablete? & $\square$ não & $\square$ sim \\
\hline Tem habilidades com Word? & $\square$ não & $\square$ alguma $\square$ muita \\
\hline Tem habilidades com PowerPoint? & $\square$ não & $\square$ muita \\
\hline Tem habilidades com Excel? & $\square$ não & $\square$ alguma $\square$ muita \\
\hline Faz pesquisas na Internet? & $\square$ nunca fiz & $\square$ em Lan House \\
\hline Onde mais acessa a Internet? & $\square$ em casa $\square$ na escola \\
\hline Usa WhatsApp? & $\square$ nunca usei & $\square$ sim \\
\hline Messenger do Facebook & $\square$ nunca usei & $\square$ sim \\
\hline Usa Skype? & $\square$ nunca usei & $\square$ sim \\
\hline Usa Hangout? & $\square$ nunca usei & $\square$ sim \\
\hline Usa Facebook? & $\square$ nunca usei & $\square$ sim \\
\hline Usa Instagram? & $\square$ nunca usei & $\square$ sim \\
\hline Usa Twitter? & $\square$ nunca usei & $\square$ sim \\
\hline Participa de jogos online ? & $\square$ nunca participei & $\square$ pouco $\square$ bastante \\
\hline Tem um Blog? & $\square$ não & $\square$ já tive \\
\hline Costuma ver Blogs? & $\square$ nunca & $\square$ sim \\
\hline
\end{tabular}




\section{APÊNDICE F - Questionário B - Sondagem diagnóstica com alunos}

\section{(Adaptação do Inventário de Pesquisa do Grupo Alph@ 2015)}

Prezado (a) estudante,

Com o objetivo de conhecer sua aproximação com as Tecnologias Digitais de Informação e Comunicação, gostaria que respondesse as questões abaixo.

Obrigada,

Profa. Fátima Rios, doutoranda Faculdade de Educação da USP

\section{Parte 1 - Identificação}

Sexo: $\square$ Feminino $\square$ Masculino

Idade:

Ano/Turma:

Nome (opcional):

\section{Parte 2 - Inventário de Fluência Digital}

1 Marque com um "X" a opção que indica seu caso nos itens abaixo

\begin{tabular}{l|ll}
\hline \multicolumn{1}{c}{ Pergunta } & \multicolumn{2}{c}{ Sua resposta } \\
\hline Tem e-mail? & $\square$ não & $\square$ sim, qual? \\
\hline Tem celular? & $\square$ não & $\square$ sim \\
\hline Tem computador ou laptop em casa? & $\square$ não & $\square$ sim \\
\hline Tem tablet? & $\square$ não & $\square$ sim \\
\hline Tem habilidades com Word? & $\square$ não & $\square$ alguma $\square$ muita \\
\hline Tem habilidades com PowerPoint? & $\square$ não & $\square$ alguma $\square$ muita \\
\hline Tem habilidades com Excel? & $\square$ não & $\square$ algumas vezes \\
\hline Faz pesquisas na Internet? & $\square$ nunca fiz & $\square$ bastante \\
\hline Onde mais acessa a Internet? & $\square$ em casa $\square$ na escola & $\square$ em Lan House \\
\hline Usa WhatsApp? & $\square$ nunca usei & $\square$ sim \\
\hline Messenger do Facebook & $\square$ nunca usei & $\square$ sim \\
\hline Usa Skype? & $\square$ nunca usei & $\square$ sim \\
\hline Usa Hangout? & $\square$ nunca usei & $\square$ sim \\
\hline Usa Facebook? & $\square$ nunca usei & $\square$ sim \\
\hline Usa Instagram? & $\square$ nunca usei & $\square$ sim \\
\hline Usa Twitter? & $\square$ nunca usei & $\square$ sim \\
\hline Participa de jogos online ? & $\square$ nunca participei & $\square$ pouco \\
\hline Tem um Blog? & $\square$ não & $\square$ já tive \\
\hline Costuma ver Blogs? & $\square$ nunca & $\square$ bastante \\
\hline
\end{tabular}

2 Quais as suas preferências de leitura?

Marque com um "X" a sua opção ou indique outra

\begin{tabular}{llc}
\hline Quadrinhos & na Internet $\square$ & impressos $\square$ \\
Livros & na Internet $\square$ & impressos $\square$ \\
Poemas & na Internet $\square$ & impressos $\square$ \\
Jornais & na Internet $\square$ & impressos $\square$ \\
Revistas & na Internet $\square$ & impressas $\square$ \\
Blogs & na Internet $\square$ & \\
Outros & na Internet $\square$ & impressos $\square$ \\
\hline
\end{tabular}

3 Para você, como deve ser uma boa informação na Internet?

4 Aponte até três riscos que podem estar presente ao usar a Internet. 


\section{APÊNDICE G - Questionário C - Avaliação da Ação por professores}

Prezado (a) professor (a),

Gostaria de conhecer suas impressões sobre nossa pesquisa e sobre o uso das tecnologias digitais nas Oficinas de Orientação de Estudos.

Obrigada,

Profa. Fátima Rios, doutoranda Faculdade de Educação da USP

Nome (opcional):

1 A partir da Ação implementada, como você percebe suas habilidades em relação às tecnologias digitais trabalhadas?

Marcar apenas uma opção por linha.

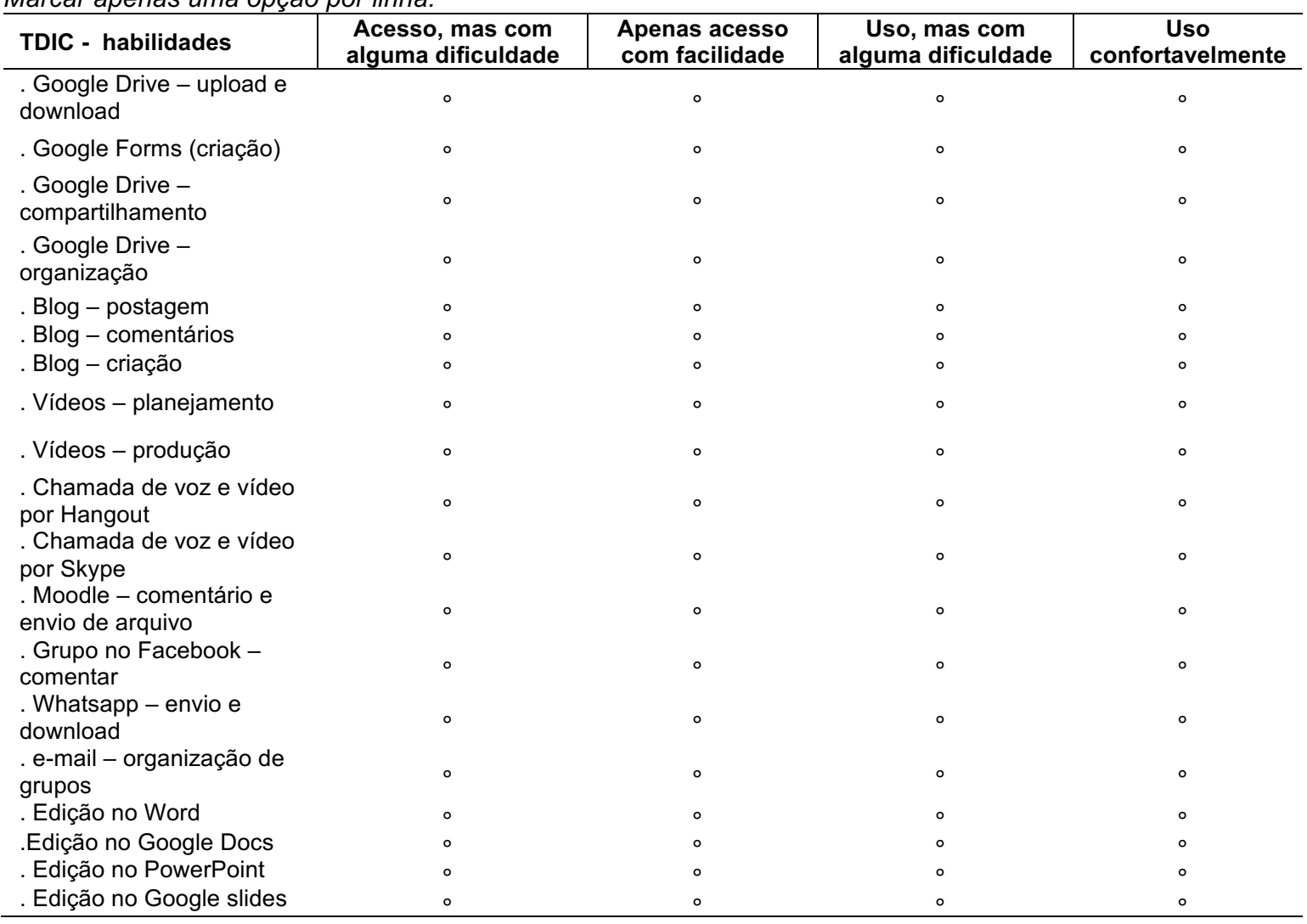

2 Das tecnologias digitais trabalhadas com os alunos nas Oficinas durante esta pesquisa, quais pretende continuar usando na escola?

Marcar apenas uma opção por linha.

\begin{tabular}{l|c|c|c}
\multicolumn{1}{c|}{ TDIC } & $\begin{array}{c}\text { Não apreciei essa } \\
\text { tecnologia }\end{array}$ & $\begin{array}{c}\text { Apreciei essa } \\
\text { tecnologia, mas não } \\
\text { pretendo mais usar }\end{array}$ & $\begin{array}{c}\text { Apreciei essa tecnologia e } \\
\text { pretendo continuar } \\
\text { usando }\end{array}$ \\
\hline . Google Drive (Docs, slides) & $\circ$ & $\circ$ & $\circ$ \\
. Google Forms & $\circ$ & $\circ$ & $\circ$ \\
. Blog Pesquisa Nobre & $\circ$ & $\circ$ & $\circ$ \\
.Vídeos & $\circ$ & $\circ$ & $\circ$ \\
. Hangout & $\circ$ & $\circ$ & $\circ$ \\
. e-mail & $\circ$ & $\circ$ & $\circ$ \\
. Skype & $\circ$ & $\circ$ & $\circ$ \\
\hline
\end{tabular}


3 Com a sua participação nesta pesquisa, em que medida você se sente fortalecido nas ações didáticas com apoio de TDIC, relacionadas abaixo?

\begin{tabular}{|c|c|c|c|}
\hline Ação didática & $\begin{array}{l}\text { A pesquisa não } \\
\text { contribuiu, não fui } \\
\text { fortalecido, } \\
\text { não sei usar }\end{array}$ & $\begin{array}{c}\text { A pesquisa não } \\
\text { contribuiu, fui pouco } \\
\text { fortalecido, já sabia } \\
\text { usar }\end{array}$ & $\begin{array}{c}\text { A pesquisa } \\
\text { contribuiu, fui } \\
\text { muito fortalecido, } \\
\text { consigo usar com } \\
\text { facilidade }\end{array}$ \\
\hline $\begin{array}{l}\text {. Buscar informações na Internet, } \\
\text { usando filtros }\end{array}$ & $\circ$ & $\circ$ & ० \\
\hline Selecionar informações relevantes & $\circ$ & $\circ$ & $\circ$ \\
\hline $\begin{array}{l}\text { Organizar aulas usando o Blog } \\
\text {. Elaborar postagens de conteúdos no }\end{array}$ & $\circ$ & $\circ$ & $\circ$ \\
\hline $\begin{array}{l}\text { Blog } \\
\text {. Provocar os alunos a aprenderem }\end{array}$ & $\circ$ & $\circ$ & $\circ$ \\
\hline $\begin{array}{l}\text { mais, comentando sobre o que } \\
\text { escrevem no Blog }\end{array}$ & $\circ$ & $\circ$ & $\circ$ \\
\hline $\begin{array}{l}\text { Avaliar os alunos em trabalhos com } \\
\text { diversas TDIC diversas }\end{array}$ & $\circ$ & $\circ$ & $\circ$ \\
\hline
\end{tabular}

4 Qual a utilidade dos conteúdos veiculados nos recursos abaixo para suas ações didáticas com apoio de TDIC?

\begin{tabular}{|c|c|c|c|c|}
\hline Recursos didáticos & $\begin{array}{l}\text { Não vi o } \\
\text { material }\end{array}$ & $\begin{array}{c}\text { Vi o material, mas não } \\
\text { considero o conteúdo } \\
\text { importante para minha } \\
\text { prática docente }\end{array}$ & $\begin{array}{c}\text { Vi o material, mas } \\
\text { não fiz uso na } \\
\text { minha prática } \\
\text { docente }\end{array}$ & $\begin{array}{c}\text { Vi o material, o } \\
\text { conteúdo foi (é) útil } \\
\text { para minha prática } \\
\text { docente }\end{array}$ \\
\hline $\begin{array}{l}\text { Uso pedagógico de } \\
\text { tecnologias digitais }\end{array}$ & $\circ$ & $\circ$ & $\circ$ & $\circ$ \\
\hline $\begin{array}{l}\text { Pesquisando na Internet } \\
\text {. Como selecionar uma }\end{array}$ & $\circ$ & $\circ$ & $\circ$ & $\circ$ \\
\hline $\begin{array}{l}\text { informação na Internet } \\
\text {. Apresentação de }\end{array}$ & $\circ$ & $\circ$ & $\circ$ & $\circ$ \\
\hline $\begin{array}{l}\text { trabalhos escolares com } \\
\text { TDIC }\end{array}$ & $\circ$ & $\circ$ & $\circ$ & $\circ$ \\
\hline $\begin{array}{l}\text { Como criar um Blog } \\
\text { Como fazer postagens }\end{array}$ & $\circ$ & $\circ$ & $\circ$ & $\circ$ \\
\hline $\begin{array}{l}\text { no } B l o g \text {, inserindo } \\
\text { imagens, vídeos e pdf. }\end{array}$ & $\circ$ & $\circ$ & $\circ$ & $\circ$ \\
\hline . Como inserir gadget & $\circ$ & $\circ$ & $\circ$ & $\circ$ \\
\hline $\begin{array}{l}\text { Como produzir um vídeo } \\
\text { retrô }\end{array}$ & $\circ$ & $\circ$ & $\circ$ & $\circ$ \\
\hline $\begin{array}{l}\text { Como fazer referências } \\
\text { de pesquisa da Internet }\end{array}$ & $\circ$ & $\circ$ & $\circ$ & $\circ$ \\
\hline
\end{tabular}

$5 \mathrm{Na}$ sua opinião, aponte até três desafios com a experiência do uso das TDIC na sua prática docente e para os alunos durante esta pesquisa.

$6 \mathrm{Na}$ sua opinião, aponte até três contribuições do uso de TDIC para a sua prática docente e para os alunos.

7 Que contribuições esta pesquisa trouxe a você? O que nos sugere?

8 Como você percebe o atual estado de Letramento Digital dos alunos? 


\section{APÊNDICE H - Questionário D - Avaliação da Ação por alunos}

Caro estudante,

Gostaria de conhecer suas impressões sobre o uso das tecnologias digitais nas Oficinas de Orientação de Estudos.

Obrigada,

Profa. Fátima Rios, doutoranda Faculdade de Educação da USP

Nome (opcional):

Ano/Turma:

1 Participou do Blog Pesquisa Nobre? Onde mais acessou?

Marque apenas uma resposta.

a) sim, acessei somente na escola

b) sim, acessei somente fora da escola

c) sim, acessei na escola e fora da escola

d) nunca participei do Blog

2 Se você deixou de acessar o Blog na escola, qual foi o principal motivo?

Marque apenas uma resposta.

a) eu esquecia meu RA

b) eu esquecia meu e-mail ou minha senha do Google (gmail)

c) eu dividia o computador da escola com outros colegas

d) Outro:

3 Aponte até três desafios que você encontrou para usar o Blog nas Oficinas de Orientação de Estudos.

4 Você gostaria que o Blog Pesquisa Nobre continuasse na escola?

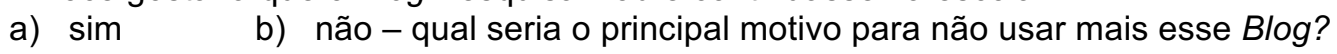

5 Marque abaixo as ações que você realizou na elaboração de trabalhos com mídias nas Oficinas de Orientação de Estudos.

Marque todas as opções que se aplicam ao seu caso.

a) fiz busca de informações na Internet

b) selecionei informações que considerei relevante

c) escrevi trabalho sobre o assunto

d) fiz rascunho dos slides

e) produzi slides, usando PowerPoint

f) produzi slides, usando o Google slides

g) compartilhei os slides com o professor ou colegas

h) apresentei oralmente, com slides na minha turma

i) apresentei oralmente, via Skype, para convidados

j) Outro:

6 Você realizou uma ou mais ações da questão anterior, durante os projetos com mídias, realizados nas Oficinas de Orientação de Estudos? Sim? Então, fale um pouco sobre sua experiência.

7 Conte o que aprendeu nas Oficinas de Orientação de Estudos, usando as mídias.

8 O que você mudaria nas Oficinas de Orientação de Estudos?

Muito obrigada! 


\section{APÊNDICE I - Questionário E - Avaliação da Ação por observadores}

Prezado (a) professor (a), gostaria de conhecer suas impressões sobre nossa pesquisa e sobre o uso das tecnologias digitais nas Oficinas de Orientação de Estudos.

Obrigada,

Profa. Fátima Rios, doutoranda Faculdade de Educação da USP

Identificação: Nome

1 Em 2015, você tomou conhecimento dos trabalhos/resultados das Oficinas de Orientação de Estudos?

Marcar apenas uma opção.

a) não

b) sim, acompanhei com alguma regularidade essa Oficina ao longo do ano

c) sim, somente na Feira Cultural

d) sim, somente na avaliação coletiva (corpo docente e gestor) no final de ano

2 E em 2016, você tomou conhecimento dos trabalhos/resultados das Oficinas de Orientação de Estudos?

Marcar apenas uma opção.

a) não

b) sim, acompanhei com alguma regularidade essa Oficina ao longo do ano

c) sim, somente na Feira Cultural

d) sim, somente na avaliação coletiva (corpo docente e gestor) no final de ano

3 Você é seguidor do Blog Pesquisa Nobre das Oficinas de Orientação de Estudos? Marcar apenas uma opção.
a) $\operatorname{sim}$
b) não

4 Você percebeu alguma mudança nas Oficinas de Orientação de Estudos a partir de 2016? Se observou, quais foram essas mudanças?

$5 \mathrm{Na}$ sua opinião, aponte até três desafios que você observou com a experiência de tecnologias digitais nas Oficinas de Orientação de Estudos.

$6 \mathrm{Na}$ sua opinião, aponte até três contribuições do uso de tecnologias digitais nas Oficinas de Orientação de Estudos com a pesquisa. 


\section{APÊNDICE J - Guia para Entrevistas Semiestruturadas}

\section{Questões realizadas}

Fase: Diagnóstico

\section{Participantes: Coordenação pedagógica e Direção da Escola}

1. Como a Escola se organizou ao longo dos anos?

2. Quais os documentos que orientam as atividades curriculares da Escola em 2016?

3. Como se constitui o quadro de professores da Escola?

4. E a formação dos professores desta Escola, como tem sido?

5. Como ocorre o planejamento dos professores?

6. As mídias são utilizadas na Escola?

7. Como funciona o Laboratório de Informática?

\section{Participantes: Professores de Oficina de Orientação de Estudos}

Referente ao processo educativo nas Oficinas de Orientação de Estudos e o uso de TDIC em 2015

1. Como foi a sua experiência com Oficina de Orientação de Estudos no ano de 2015?

2. Como foram os trabalhos dos alunos nas Oficinas de Orientação de Estudos em 2015?

3. Trabalharam em termos de competências e habilidades?

4. E qual foram os conteúdos foram trabalhados?

5. E os recursos didáticos utilizados?

6. Qual a forma e critérios de avaliação planejada e realizada?

7. Como foram as produções dos alunos?

Referente ao processo educativo nas Oficinas de Orientação de Estudos e o uso de tecnologias digitais em 2016

1. Qual é a sua expectativa para a Oficina de Orientação de Estudos em 2016 ?

2. O que e como pretende trabalhar nas Oficinas de Orientação de Estudos? 


\section{APÊNDICE K - Guia para Grupo Focal}

\section{Questões orientadoras}

Participantes: professores, alunos e observadores

Fase: Planejamento e implementação da Ação

1. Como está sendo a experiência com as mídias nas Oficinas de Orientação de Estudos?

2. Que desafios a pesquisa trouxe à prática com as mídias nas Oficinas de Orientação de Estudos?

\section{Fase: Avaliação da Ação}

1. Como foi a experiência com ação com as mídias nas Oficinas de Orientação de Estudos?

2. Que desafios a pesquisa trouxe na prática educativa?

3. Que contribuições a pesquisa trouxe à prática educativa? 


\section{APÊNDICE L - Síntese das categorias analisadas na pesquisa, por dimensão}

\begin{tabular}{|c|c|c|c|c|}
\hline \multicolumn{5}{|c|}{ Dimensão Infraestrutura física/tecnológica } \\
\hline Categoria & $\begin{array}{c}\text { Cenário } \\
\text { existente }\end{array}$ & Ações da escola & $\begin{array}{c}\text { Período da } \\
\text { Pesquisa }\end{array}$ & Resultados \\
\hline $\begin{array}{l}\text { Infraestrutura } \\
\text { física }\end{array}$ & $\begin{array}{l}\text { Infraestrutura } \\
\text { física insuficiente: } \\
\text { número de salas } \\
\text { de aula, } \\
\text { equipamentos, } \\
\text { Laboratórios de } \\
\text { Informática, } \\
\text { carteiras }\end{array}$ & $\begin{array}{l}\text { Uso inadequado } \\
\text { do Laboratório de } \\
\text { Informática, } \\
\text { servindo apenas } \\
\text { de espaço físico } \\
\text { para as aulas } \\
\text { tradicionais }\end{array}$ & Sem alterações & Sem alterações \\
\hline $\begin{array}{l}\text { Infraestrutura } \\
\text { tecnológica }\end{array}$ & $\begin{array}{l}\text { Infraestrutura } \\
\text { tecnológica na } \\
\text { escola precária: } \\
\text { número e } \\
\text { condições de } \\
\text { computadores e } \\
\text { de recursos } \\
\text { digitais didáticos; } \\
\text { energia elétrica } \\
\text { instável; potência } \\
\text { e velocidade da } \\
\text { Internet Wi-Fi e } \\
\text { banda larga } \\
\text { instável }\end{array}$ & $\begin{array}{l}\text { Ações de ensino e } \\
\text { aprendizagem } \\
\text { sem uso de TDIC }\end{array}$ & $\begin{array}{l}\text { Manutenção } \\
\text { periódica dos } \\
\text { computadores; } \\
\text { compra de som } \\
\text { para } \\
\text { computadores; } \\
\text { lâmpada para } \\
\text { datashow }\end{array}$ & $\begin{array}{l}\text { Ações com uso de } \\
\text { TDIC na OOE e } \\
\text { em outras } \\
\text { disciplinas } \\
\text { Expansão da } \\
\text { Banda Larga e } \\
W i-F i \\
\text { Doação de um } \\
\text { notebook }\end{array}$ \\
\hline $\begin{array}{l}\text { Uso de celulares } \\
\text { na escola e da } \\
W i-F i\end{array}$ & $\begin{array}{l}\text { Uso de celulares } \\
\text { na escola } \\
\text { restritivo por Lei } \\
\text { estadual e } \\
\text { restrição da Wi-Fi } \\
\text { pela Direção da } \\
\text { Escola }\end{array}$ & $\begin{array}{l}\text { Ações de ensino e } \\
\text { aprendizagem } \\
\text { sem uso regular } \\
\text { de celulares } \\
\text { durante as aulas }\end{array}$ & $\begin{array}{l}\text { Liberação do uso } \\
\text { de celulares, pela } \\
\text { Direção da } \\
\text { Escola, } \\
\text { disponibilização } \\
\text { da Wi-Fi }\end{array}$ & $\begin{array}{l}\text { Uso de celulares } \\
\text { nas aulas da OOE }\end{array}$ \\
\hline \multicolumn{5}{|c|}{ Dimensão Administrativa-Pedagógica } \\
\hline Categoria & $\begin{array}{c}\text { Cenário } \\
\text { existente }\end{array}$ & Ações da escola & $\begin{array}{l}\text { Período da } \\
\text { Pesquisa }\end{array}$ & Resultados \\
\hline Quadro docente & $\begin{array}{l}\text { Quadro docente } \\
\text { na escola rotativo } \\
\text { pela contratação } \\
\text { de professores } \\
\text { temporários }\end{array}$ & $\begin{array}{l}\text { Insegurança } \\
\text { profissional; } \\
\text { redistribuição } \\
\text { anual dos } \\
\text { componentes } \\
\text { curriculares com } \\
\text { descontinuidade } \\
\text { do trabalho } \\
\text { docente; } \\
\text { mudanças e } \\
\text { descontinuidade } \\
\text { dos projetos com } \\
\text { alunos e docentes }\end{array}$ & Sem alterações & Sem alterações \\
\hline $\begin{array}{l}\text { Horário do } \\
\text { Laboratório }\end{array}$ & $\begin{array}{l}\text { Falta de } \\
\text { organização do } \\
\text { horário para uso } \\
\text { do Laboratório de } \\
\text { Informática }\end{array}$ & $\begin{array}{l}\text { Uso inadequado } \\
\text { do Laboratório de } \\
\text { Informática, } \\
\text { servindo apenas } \\
\text { de espaço físico } \\
\text { para as aulas }\end{array}$ & $\begin{array}{l}\text { Agendamento dos } \\
\text { horários para uso } \\
\text { do espaço do } \\
\text { Laboratório de } \\
\text { forma livre, em } \\
\text { mural, de iniciativa } \\
\text { individual }\end{array}$ & $\begin{array}{l}\text { Uso adequado do } \\
\text { Laboratório de } \\
\text { Informática na } \\
\text { OOE, porém com } \\
\text { horários } \\
\text { insuficientes para } \\
\text { a nova demanda }\end{array}$ \\
\hline Tempo docente & $\begin{array}{l}\text { Tempo docente } \\
\text { dividido entre } \\
\text { várias lotações } \\
\text { em escolas na } \\
\text { Região }\end{array}$ & $\begin{array}{l}\text { Participação } \\
\text { docente nas } \\
\text { atividades } \\
\text { escolares restritas } \\
\text { aos horários de } \\
\text { aula e HTPC } \\
\end{array}$ & Sem alterações & Sem alterações \\
\hline
\end{tabular}


Continuação

\begin{tabular}{|c|c|c|c|c|}
\hline \multicolumn{5}{|c|}{ Dimensão Didática-Pedagógica } \\
\hline Categoria & $\begin{array}{l}\text { Cenário } \\
\text { existente }\end{array}$ & Ações da escola & $\begin{array}{c}\text { Período da } \\
\text { Pesquisa }\end{array}$ & Resultados \\
\hline $\begin{array}{l}\text { Formação } \\
\text { permanente de } \\
\text { professores }\end{array}$ & $\begin{array}{l}\text { Inexistência de } \\
\text { Formação } \\
\text { permanente dos } \\
\text { professores para } \\
\text { uso de TDIC }\end{array}$ & $\begin{array}{l}\text { Insegurança } \\
\text { docente nas } \\
\text { ações didáticas; } \\
\text { ausência de } \\
\text { planejamento e } \\
\text { para uso de TDIC }\end{array}$ & $\begin{array}{l}\text { Ação de formação } \\
\text { com a pesquisa }\end{array}$ & $\begin{array}{l}\text { Incorporação de } \\
\text { novos } \\
\text { conhecimentos, } \\
\text { habilidades e } \\
\text { atitudes } \\
\text { (pedagógicos e } \\
\text { tecnológicos) }\end{array}$ \\
\hline $\begin{array}{l}\text { Planejamento } \\
\text { didático }\end{array}$ & $\begin{array}{l}\text { Planejamento } \\
\text { entre os pares } \\
\text { comprometido } \\
\text { durante o HTPC } \\
\text { em função de } \\
\text { pauta diversa e } \\
\text { desencontro de } \\
\text { professores }\end{array}$ & $\begin{array}{l}\text { Trabalho docente } \\
\text { individualizado; } \\
\text { comprometimento } \\
\text { de projetos } \\
\text { pedagógicos e de } \\
\text { estudos } \\
\text { interdisciplinares } \\
\text { com apoio de } \\
\text { TDIC } \\
\end{array}$ & $\begin{array}{l}\text { Planejamento } \\
\text { após os HTPC } \\
\text { com a } \\
\text { pesquisadora }\end{array}$ & $\begin{array}{l}\text { Trabalho em } \\
\text { parceria entre os } \\
\text { professores com } \\
\text { orientação da } \\
\text { pesquisadora, } \\
\text { usando } \\
\text { estratégias } \\
\text { presenciais e a } \\
\text { distância } \\
\end{array}$ \\
\hline $\begin{array}{l}\text { Conhecimentos } \\
\text { e Habilidades } \\
\text { Didáticas com } \\
\text { TDIC }\end{array}$ & $\begin{array}{l}\text { Conhecimento } \\
\text { teórico e prático } \\
\text { tradicional (aulas } \\
\text { expositivas e } \\
\text { exercícios) }\end{array}$ & $\begin{array}{l}\text { Dificuldades para } \\
\text { o planejamento } \\
\text { didático e } \\
\text { avaliação dos } \\
\text { alunos sem TDIC }\end{array}$ & $\begin{array}{l}\text { Conhecimento } \\
\text { teórico e prático } \\
\text { em Didática } \\
\text { estimulado com } \\
\text { TDIC }\end{array}$ & $\begin{array}{l}\text { Planejamento } \\
\text { didático e } \\
\text { avaliação dos } \\
\text { alunos com TDIC }\end{array}$ \\
\hline $\begin{array}{l}\text { Percepção/Ação } \\
\text { das novas } \\
\text { formas de } \\
\text { ensinar }\end{array}$ & $\begin{array}{l}\text { Insegurança } \\
\text { docente e } \\
\text { desconhecimento } \\
\text { de novas formas } \\
\text { de ensinar }\end{array}$ & $\begin{array}{l}\text { Ações de ensino e } \\
\text { aprendizagem } \\
\text { sem uso de TDIC } \\
\text { por insegurança e } \\
\text { receio }\end{array}$ & $\begin{array}{l}\text { Percepção } \\
\text { docente desafiada } \\
\text { acerca das novas } \\
\text { formas de ensinar }\end{array}$ & $\begin{array}{l}\text { Ações na OOE } \\
\text { com uso de TDIC } \\
\text { com } \\
\text { intencionalidade } \\
\text { educativa }\end{array}$ \\
\hline $\begin{array}{l}\text { Uso educativo } \\
\text { das TDIC }\end{array}$ & $\begin{array}{l}\text { TDIC } \\
\text { eventualmente } \\
\text { presentes no } \\
\text { planejamento e } \\
\text { nas aulas }\end{array}$ & $\begin{array}{l}\text { Ações de ensino e } \\
\text { aprendizagem } \\
\text { sem uso regular } \\
\text { de TDIC }\end{array}$ & $\begin{array}{l}\text { TDIC presentes } \\
\text { no planejamento e } \\
\text { nas aulas } \\
\text { frequentes }\end{array}$ & $\begin{array}{l}\text { Ações na OOE } \\
\text { com uso de TDIC } \\
\text { com } \\
\text { intencionalidade } \\
\text { educativa }\end{array}$ \\
\hline $\begin{array}{l}\text { Recursos } \\
\text { didáticos }\end{array}$ & $\begin{array}{l}\text { Prevalência de } \\
\text { recursos didáticos } \\
\text { manuais e } \\
\text { manuscritos; } \\
\text { aulas expositivas; } \\
\text { cópia da lousa no } \\
\text { caderno }\end{array}$ & $\begin{array}{l}\text { Ações de ensino e } \\
\text { aprendizagem } \\
\text { sem uso } \\
\text { planejado de } \\
\text { TDIC }\end{array}$ & $\begin{array}{l}\text { Incorporação de } \\
\text { recursos digitais }\end{array}$ & $\begin{array}{l}\text { Ações na OOE } \\
\text { com uso de TDIC } \\
\text { com } \\
\text { intencionalidade } \\
\text { educativa }\end{array}$ \\
\hline $\begin{array}{l}\text { Percepção/Ação } \\
\text { das novas } \\
\text { formas de } \\
\text { aprender }\end{array}$ & $\begin{array}{l}\text { Fluência digital } \\
\text { em aplicativos de } \\
\text { uso social } \\
\text { Alunos atraídos } \\
\text { pelas novas } \\
\text { formas de } \\
\text { aprender }\end{array}$ & $\begin{array}{l}\text { Abertura para o } \\
\text { uso de TDIC nas } \\
\text { aulas }\end{array}$ & $\begin{array}{l}\text { Alunos } \\
\text { interessados } \\
\text { pelas novas } \\
\text { formas de } \\
\text { aprender }\end{array}$ & $\begin{array}{l}\text { Boa participação } \\
\text { discente nas } \\
\text { atividades com } \\
\text { TDIC na OOE }\end{array}$ \\
\hline $\begin{array}{l}\text { Produção } \\
\text { discente }\end{array}$ & $\begin{array}{l}\text { Prevalência de } \\
\text { produção discente } \\
\text { manuscrita em } \\
\text { cadernos e provas }\end{array}$ & $\begin{array}{l}\text { Ações de ensino e } \\
\text { aprendizagem } \\
\text { sem uso de TDIC }\end{array}$ & $\begin{array}{l}\text { Incorporação de } \\
\text { produção discente } \\
\text { digital }\end{array}$ & $\begin{array}{l}\text { Ações discentes } \\
\text { com uso de TDIC } \\
\text { na OOE }\end{array}$ \\
\hline
\end{tabular}


Continuação

\begin{tabular}{|c|c|c|c|c|}
\hline \multicolumn{5}{|c|}{ Dimensão Pessoal } \\
\hline Categoria & $\begin{array}{l}\text { Cenário } \\
\text { existente }\end{array}$ & Ações da escola & $\begin{array}{c}\text { Período da } \\
\text { Pesquisa }\end{array}$ & Resultados \\
\hline $\begin{array}{l}\text { Condição } \\
\text { socioeconômica }\end{array}$ & $\begin{array}{l}\text { Posse de } \\
\text { equipamentos } \\
\text { eletrônicos e } \\
\text { Internet pessoal } \\
\text { com restrição } \\
\text { econômica } \\
\end{array}$ & $\begin{array}{l}\text { Uso limitado de } \\
\text { equipamentos } \\
\text { eletrônicos pessoais } \\
\text { nas aulas }\end{array}$ & $\begin{array}{l}\text { Permanece } \\
\text { inalterada }\end{array}$ & $\begin{array}{l}\text { Permanece } \\
\text { inalterada }\end{array}$ \\
\hline $\begin{array}{l}\text { Disponibilidade } \\
\text { para aprender }\end{array}$ & $\begin{array}{l}\text { Disponibilidade } \\
\text { docente para } \\
\text { aprender } \\
\text { comprometida } \\
\text { pela falta tempo } \\
\text { para formação na } \\
\text { escola }\end{array}$ & $\begin{array}{l}\text { Ausência de } \\
\text { condições favoráveis } \\
\text { para participação em } \\
\text { atividades de } \\
\text { formação para uso de } \\
\text { TDIC na escola }\end{array}$ & $\begin{array}{l}\text { Disponibilidade } \\
\text { docente e } \\
\text { discente para } \\
\text { aprender } \\
\text { manifesta } \\
\text { voluntariamente }\end{array}$ & $\begin{array}{l}\text { Participação dos } \\
\text { professores e } \\
\text { alunos em } \\
\text { atividades de } \\
\text { formação }\end{array}$ \\
\hline $\begin{array}{l}\text { Colaboração } \\
\text { docente }\end{array}$ & $\begin{array}{l}\text { Colaboração } \\
\text { comprometida }\end{array}$ & $\begin{array}{l}\text { Prevalência de } \\
\text { atividades individuais, } \\
\text { pelo tempo e } \\
\text { condições de } \\
\text { infraestrutura da } \\
\text { escola e quadro } \\
\text { docente rotativo anual }\end{array}$ & $\begin{array}{l}\text { Colaboração } \\
\text { provocada pela } \\
\text { pesquisadora }\end{array}$ & $\begin{array}{l}\text { Planejamento } \\
\text { colaborativo } \\
\text { entre os } \\
\text { professores } \\
\text { usando TDIC }\end{array}$ \\
\hline $\begin{array}{l}\text { Colaboração } \\
\text { discente }\end{array}$ & $\begin{array}{l}\text { Colaboração } \\
\text { entre os alunos } \\
\text { pouco estimulada } \\
\text { pelos professores }\end{array}$ & $\begin{array}{l}\text { Prevalência de } \\
\text { atividades individuais, } \\
\text { mesmo alunos } \\
\text { dispostos lado a lado } \\
\text { ou em grupo }\end{array}$ & $\begin{array}{l}\text { Colaboração } \\
\text { entre os alunos } \\
\text { estimulada } \\
\text { pelos } \\
\text { professores } \\
\text { para o uso de } \\
\text { TDIC }\end{array}$ & $\begin{array}{l}\text { Colaboração } \\
\text { entre os alunos } \\
\text { no uso de } \\
\text { computadores, } \\
\text { no acesso ao } \\
\text { Blog, e em } \\
\text { trabalhos dos } \\
\text { alunos, usando } \\
\text { TDIC }\end{array}$ \\
\hline $\begin{array}{l}\text { Sentimentos e } \\
\text { motivações }\end{array}$ & $\begin{array}{l}\text { Medo e } \\
\text { insegurança para } \\
\text { o uso de TDIC } \\
\text { nas aulas }\end{array}$ & $\begin{array}{l}\text { Ações de ensino e } \\
\text { aprendizagem sem } \\
\text { uso de TDI8C }\end{array}$ & $\begin{array}{l}\text { Professores e } \\
\text { alunos em } \\
\text { processo de } \\
\text { superação do } \\
\text { medo e } \\
\text { insegurança } \\
\text { para usar TDIC } \\
\text { em aulas }\end{array}$ & $\begin{array}{l}\text { Autoconfiança, } \\
\text { autoestima e } \\
\text { conquista no } \\
\text { uso de TDIC } \\
\text { com } \\
\text { apresentação } \\
\text { oral de trabalhos } \\
\text { nas aulas, em } \\
\text { atividades } \\
\text { extraclasse e } \\
\text { em eventos } \\
\text { externos; planos } \\
\text { profissionais do } \\
\text { professores } \\
\text { para o futuro }\end{array}$ \\
\hline
\end{tabular}

Fonte: Contexto da Escola Fernando Nobre (2016/2018) 


\section{APÊNDICE M - Termo de Consentimento Livre e Esclarecido}

O (a) senhor (a) ou o (a) menor pelo (a) qual é responsável está sendo convidado (a) para participar, como voluntário (a), em uma pesquisa. Após ser esclarecido (a) sobre as informações a seguir, no caso de aceitar fazer parte do estudo ou autorizar o (a) menor a fazer parte, assine ao final deste documento, que está em duas vias. Uma delas é sua e a outra é do pesquisadora responsável. Em caso de sua recusa, o (a) senhor (a) ou o (a) menor sob sua responsabilidade não será penalizado (a) de forma alguma.

\section{INFORMAÇÕES SOBRE A PESQUISA}

A pesquisa é vinculada ao Programa de Pós-graduação em Educação, da Faculdade de Educação da Universidade de São Paulo (FE/USP), em nível de doutorado, sendo orientada pela Profa. Dra. Stela Conceição Bertholo Piconez.

Título provisório do Projeto: Letramento Digital e competências

Pesquisadora Responsável: Maria de Fátima Serra Rios

Objetivo da pesquisa: Investigar o Letramento Digital no desenvolvimento da cultura digital no espaço escolar.

O participante é convidado a participar da pesquisa como voluntário, tendo a liberdade para recusar-se ou retirar seu consentimento, em qualquer fase da pesquisa, sem penalidade alguma e sem prejuízo ao seu cuidado. Não há nenhum gasto, ganho, ressarcimento ou indenização financeira na participação da pesquisa. Mesmo não havendo risco mensurável na pesquisa, eventuais danos que possam ser provocados aos participantes da pesquisa são passíveis de reparação.

A pesquisa terá início após a aprovação do Projeto pelo Comitê de Ética em Pesquisa, indicado pela Plataforma Brasil, concordância da Escola Estadual Fernando Nobre e consentimento dos participantes, mediante assinatura neste Termo.

A pesquisa terá sua coleta de dados a partir de técnicas variadas como pesquisa em documentos e em ambiente virtual, observação, questionário, entrevista, reuniões de grupos e ações didáticopedagógicas junto à Oficina Orientação de Estudo da Escola, fazendo uso de diversas tecnologias digitais.

Oferecemos a garantia de esclarecimentos, antes e durante o curso da pesquisa, e, sobretudo garantimos que a identidade do participante será preservada nos relatórios e em publicações dos resultados da pesquisa no todo ou em parte, salvaguardando o sigilo de informações confidenciais e o anonimato. Os instrumentos, gravações e transcrições serão guardados na residência da pesquisadora por um período de cinco anos a contar a defesa da tese e depois serão descartados.

Os resultados do trabalho poderão contribuir para o aprofundamento do estudo sobre Letramento Digital e como benefício pode oferecer subsídios para as boas práticas de pesquisa escolar com uso de tecnologias digitais para os alunos da Educação Básica.

Para esclarecimentos com relação às dúvidas éticas do projeto, o (a) senhor (a) poderá entrar em contato com a pesquisadora na Escola; por e-mail: fxxxxx@usp.br; por telefone (inclusive em ligações a cobrar): (11) 97760xxxx; ou no Comitê de Ética em Pesquisa com Seres Humanos do Instituto de Psicologia da Universidade de São Paulo na Av. Professor Mello Moraes, 1721. CEP 05508-030 Cidade Universitária - São Paulo/SP.

$$
\begin{gathered}
\text { Cotia (SP), } \\
\text { Maria de Fátima Serra Rios } \\
\text { Pesquisadora }
\end{gathered}
$$




\section{Consentimento de professores e observadores}

(Modelo)

$\mathrm{Eu}$

portador do RG

$\mathrm{n}^{\circ}$. abaixo assinado (a), concordo em participar da pesquisa sobre Letramento Digital e competências, orientada pela Profa. Dra. Stela Conceição Bertholo Piconez, do Programa de Pós-graduação em Educação, em nível de doutorado, da Faculdade de Educação da Universidade de São Paulo (FE/USP).

Fui devidamente informado (a) e esclarecido (a) pela pesquisadora Profa. Doutoranda Maria de Fátima Serra Rios sobre a pesquisa, sobre os procedimentos nela envolvidos, quanto aos riscos e benefícios decorrentes de minha participação. Foi-me garantido o anonimato em qualquer divulgação dos resultados da pesquisa e que posso retirar meu consentimento a qualquer momento, sem que isto leve à qualquer penalidade.

Nestes termos, consinto que as minhas informações sejam utilizadas no desenvolvimento da referida pesquisa.

Cotia (SP), _ _ I

Concordo em participar da pesquisa.

Assinatura do participante:

\section{Consentimento dos alunos (menor de idade)}

(Modelo)

Eu,

portador do RG

$\mathrm{n}^{\circ}$. responsável por

aluno (a) da Escola Estadual Fernando Nobre, autorizo a sua participação como voluntário (a), caso ele(a) deseje participar da pesquisa sobre Letramento Digital e competências, orientada pela Profa. Dra. Stela Conceição Bertholo Piconez, do Programa de Pós-graduação em Educação, em nível de doutorado, da Faculdade de Educação da Universidade de São Paulo (FE/USP).

Fui devidamente informado (a) e esclarecido (a) pela pesquisadora Profa. Doutoranda Maria de Fátima Serra Rios sobre a pesquisa, sobre os procedimentos nela envolvidos, quanto aos riscos e benefícios decorrentes da participação do (a) menor sob minha responsabilidade. Foi-me garantido o anonimato do (a) menor em qualquer divulgação dos resultados da pesquisa, e que posso retirar meu consentimento a qualquer momento, sem que isto leve à qualquer penalidade.

Cotia (SP), 1

Concordo em participar da pesquisa.

Assinatura do participante (menor):

Nestes termos, autorizo a participação do menor sob minha responsabilidade.

Assinatura do responsável pelo participante: 


\section{APÊNDICE N - Estruturantes didáticos no design pedagógico}

Objetivos - Orientar e fortalecer as ações de: buscar e selecionar dados e informações na Internet; identificar uma informação relevante; planejar e organizar, comunicar e informar conteúdos; produzir e colaborar em um trabalho na nuvem; como fazer referências de pesquisas; provocar cognitivamente e avaliar os alunos; usar as TDIC om intencionalidade educativa; usar a Internet de modo seguro.

Quadro 4.1 - Estruturantes didáticos no Design pedagógico

\begin{tabular}{|c|c|c|}
\hline Conteúdos & Formas de abordagem & Recursos didáticos ${ }^{67}$ \\
\hline $\begin{array}{l}1 \text { Planejamento e } \\
\text { Organização das aulas } \\
\text { com TDIC }\end{array}$ & $\begin{array}{l}\text { - Orientação aos professores } \\
\text { presencial e por Hangout, } \\
\text { Facebook, WhatsApp e } \\
\text { Plataforma Moodle, com } \\
\text { apresentação de slides } \\
\text { - Leitura e discussão de } \\
\text { planos didáticos das Oficinas }\end{array}$ & $\begin{array}{l}\text { - Uso didático-pedagógico de } \\
\text { TDIC: algumas orientações } \\
\text { (slides) } \\
\text { - Ferramentas de busca, } \\
\text { produção e publicação } \\
\text { (slides) }\end{array}$ \\
\hline $\begin{array}{l}2 \text { Critérios para atividades } \\
\text { discentes }\end{array}$ & $\begin{array}{l}\text { - Orientação presencial e a } \\
\text { distância aos professores } \\
\text { (Hangout), com } \\
\text { apresentação de slides }\end{array}$ & $\begin{array}{l}\text { - Uso didático-pedagógico de } \\
\text { TDIC: algumas orientações } \\
\text { (slides) }\end{array}$ \\
\hline $\begin{array}{l}3 \text { Ciclo de Ações Educativas } \\
\text { apoiadas por TDIC }\end{array}$ & $\begin{array}{l}\text { - Orientação aos professores } \\
\text { presencial e por Hangout, } \\
\text { Facebook, WhatsApp e } \\
\text { Plataforma Moodle, com } \\
\text { apresentação de slides }\end{array}$ & $\begin{array}{l}\text { - Uso didático-pedagógico de } \\
\text { TDIC: algumas orientações } \\
\text { (slides) }\end{array}$ \\
\hline $\begin{array}{l}4 \text { Segurança e Cuidados no } \\
\text { uso das TDIC (riscos, } \\
\text { respeito às ideias, às } \\
\text { pessoas, integridade e } \\
\text { privacidade) }\end{array}$ & $\begin{array}{l}\text { - Sondagem com alunos no } \\
\text { Google Forms } \\
\text { - Apresentação de resultados } \\
\text { da sondagem em slides aos } \\
\text { professores e observadores } \\
\text { - Orientação aos professores } \\
\text { e alunos na apresentação de } \\
\text { trabalhos, presencial e via } \\
\text { Skype }\end{array}$ & $\begin{array}{l}\text { - Como realizar um trabalho } \\
\text { escolar com Tecnologias } \\
\text { Digitais (slides) }\end{array}$ \\
\hline $\begin{array}{l}5 \text { Ciclo de Ações Educativas } \\
\text { apoiadas por TDIC: buscar } \\
\text { e selecionar informação na } \\
\text { Internet }\end{array}$ & $\begin{array}{l}\text { - Orientação presencial, com } \\
\text { apresentação de slides aos } \\
\text { professores e alunos }\end{array}$ & $\begin{array}{l}\text { - Como buscar e selecionar } \\
\text { informações na Internet } \\
\text { (slides) }\end{array}$ \\
\hline $\begin{array}{c}6 \text { Pesquisa na Internet (sites } \\
\text { e operadores de busca) }\end{array}$ & $\begin{array}{l}\text { - Orientação presencial, com } \\
\text { apresentação de videoaula } \\
\text { aos professores e alunos }\end{array}$ & $\begin{array}{l}\text { - Como pesquisar na Internet } \\
\text { (videoaula) }\end{array}$ \\
\hline $\begin{array}{l}7 \text { Critérios para selecionar } \\
\text { uma informação relevante } \\
\text { (apropriada, autêntica, } \\
\text { ampla, atraente, } \\
\text { atualizada) }\end{array}$ & $\begin{array}{l}\text { - Orientação presencial, com } \\
\text { apresentação de slides aos } \\
\text { professores e alunos }\end{array}$ & $\begin{array}{l}\text { - Como identificar uma } \\
\text { informação relevante (slides) }\end{array}$ \\
\hline $\begin{array}{l}8 \text { Ciclo de Ações Educativas } \\
\text { apoiadas por TDIC: } \\
\text { planejar e organizar } \\
\text { conteúdos }\end{array}$ & $\begin{array}{l}\text { - Orientação presencial, com } \\
\text { apresentação de slides aos } \\
\text { professores e alunos }\end{array}$ & $\begin{array}{l}\text { - Como planejar e organizar } \\
\text { a apresentação do trabalho } \\
\text { escolar com tecnologias } \\
\text { digitais (slides) }\end{array}$ \\
\hline
\end{tabular}

${ }^{67}$ Recursos disponíveis em: <http://cursosextensao.usp.br/course/view.php?id=264>; <http://pesquisanobre. blogspot.com.br>. 


\begin{tabular}{|c|c|c|}
\hline Conteúdos & Formas de abordagem & Recursos didáticos \\
\hline $\begin{array}{l}9 \text { Planejar e Organizar com } \\
\text { Google Drive (docs, slides, } \\
\text { Forms) Word, PowerPoint, } \\
\text { PDF }\end{array}$ & $\begin{array}{l}\text { - Orientação presencial aos } \\
\text { professores e alunos com } \\
\text { exercícios práticos }\end{array}$ & $\begin{array}{l}\text { - Aplicativos: Google Drive } \\
\text { (docs, slides, Forms) Word, } \\
\text { PowerPoint, PDF. }\end{array}$ \\
\hline $\begin{array}{l}10 \text { Ciclo de Ações } \\
\text { Educativas apoiadas por } \\
\text { TDIC: comunicar e } \\
\text { informar conteúdos }\end{array}$ & $\begin{array}{l}\text { - Orientação presencial, com } \\
\text { apresentação de slides aos } \\
\text { professores e alunos }\end{array}$ & $\begin{array}{l}\text { - Como comunicar e informar } \\
\text { sobre um tema estudado } \\
\text { (slides) }\end{array}$ \\
\hline $\begin{array}{l}11 \text { Ciclo de Ações } \\
\text { Educativas apoiadas por } \\
\text { TDIC: produzir e colaborar } \\
\text { em um trabalho na nuvem }\end{array}$ & $\begin{array}{l}\text { - Orientação presencial, com } \\
\text { apresentação de slides aos } \\
\text { professores e alunos }\end{array}$ & $\begin{array}{l}\text { - Como produzir um trabalho } \\
\text { escolar na nuvem Google } \\
\text { (slides) }\end{array}$ \\
\hline $\begin{array}{l}12 \text { Referências nos } \\
\text { trabalhos de pesquisa } \\
\text { escolares }\end{array}$ & $\begin{array}{l}\text { - Orientação presencial, com } \\
\text { apresentação de videoaula } \\
\text { aos professores e alunos }\end{array}$ & $\begin{array}{l}\text { - Como fazer as referências } \\
\text { da pesquisa (videoaula) }\end{array}$ \\
\hline $\begin{array}{l}13 \text { Comunicar e Informar } \\
\text { com Blog }\end{array}$ & $\begin{array}{l}\text { - Oficina com alunos para } \\
\text { criação de blogs com } \\
\text { apresentação de slides e } \\
\text { exercícios práticos } \\
\text { - Exposição presencial, com } \\
\text { apresentação de tutoriais e } \\
\text { exercícios práticos aos } \\
\text { professores e alunos } \\
\text { - Uso dessa TDIC nas } \\
\text { Oficinas } \\
\text { - Orientação presencial e a } \\
\text { distância aos professores e } \\
\text { alunos no Aplicativo }\end{array}$ & $\begin{array}{l}\text { - Como acessar o blog } \\
\text { (slides) } \\
\text { - Como criar um blog (slides) } \\
\text { - Como postar e inserir } \\
\text { imagens, vídeos e pdf } \\
\text { (slides) } \\
\text { - Como inserir gadget } \\
\text { (slides) }\end{array}$ \\
\hline $\begin{array}{l}14 \text { Comunicar e informar } \\
\text { com vídeo narrativa }\end{array}$ & $\begin{array}{l}\text { - Produção e apresentação } \\
\text { de slides aos professores } \\
\text { - Produção de vídeos } \\
\text { narrativas com fotografias } \\
\text { das Oficinas } \\
\text { - Orientação presencial aos } \\
\text { professores e alunos }\end{array}$ & $\begin{array}{l}\text { - Como produzir um vídeo } \\
\text { retrô (slides) } \\
\text { - Aplicativo: Animoto }\end{array}$ \\
\hline $\begin{array}{l}15 \text { Comunicar e informar } \\
\text { oralmente trabalhos, via } \\
\text { Skype }\end{array}$ & $\begin{array}{l}\text { - Orientação a distância aos } \\
\text { professores e alunos em } \\
\text { apresentação oral de } \\
\text { trabalhos escolares }\end{array}$ & - Aplicativo: Skype \\
\hline $\begin{array}{l}16 \text { Ciclo de Ações } \\
\text { Educativas apoiadas por } \\
\text { TDIC: produzir e colaborar } \\
\text { em um trabalho na nuvem }\end{array}$ & $\begin{array}{l}\text { - Orientação presencial, com } \\
\text { apresentação de slides aos } \\
\text { professores e alunos }\end{array}$ & $\begin{array}{l}\text { - Como produzir um trabalho } \\
\text { escolar na nuvem Google } \\
\text { (slides) }\end{array}$ \\
\hline
\end{tabular}




\section{APÊNDICE O - Dados Estatísticos da Pesquisa}

Gráfico 3.1 - Proporção de professores, por aproximação com TDIC

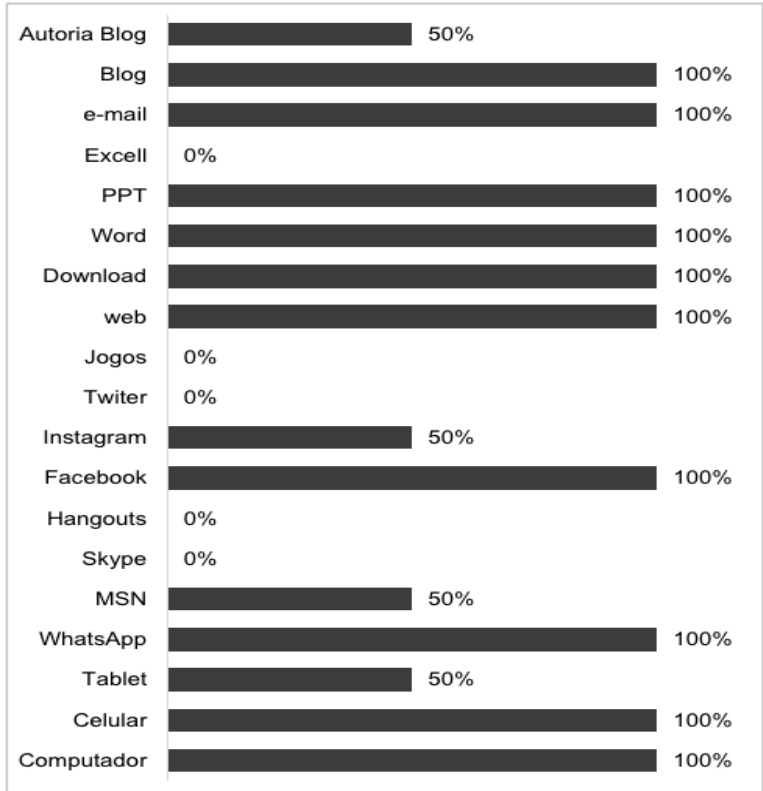

Fonte: Pesquisa da autora (2018)

Gráfico 3.2 - Proporção de alunos, por aproximação com TDIC

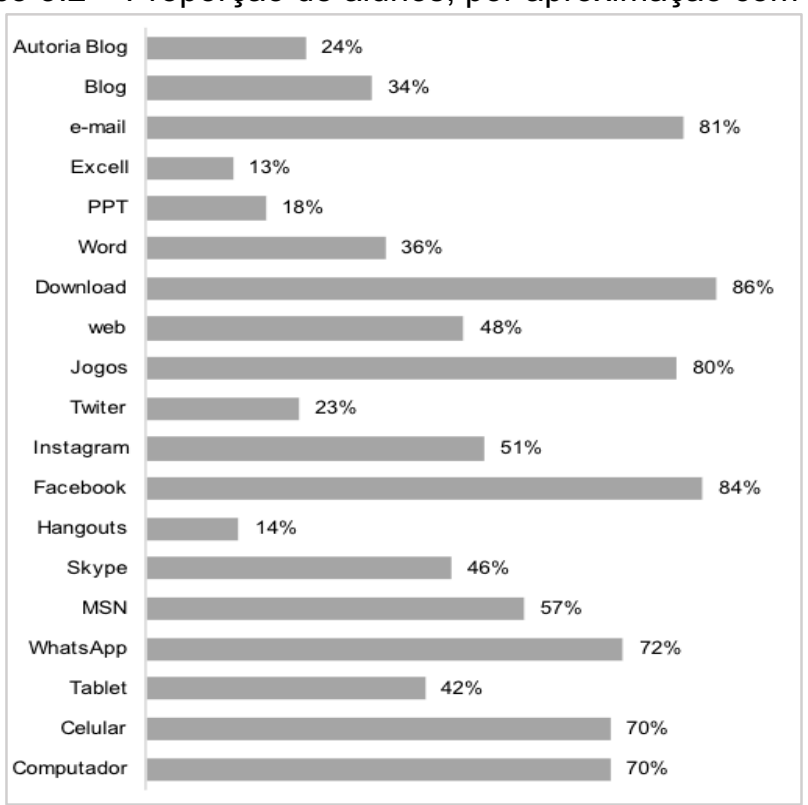

Fonte: Pesquisa da autora (2018) 
Tabela 3.1 - Fatores de perdas e danos no uso da Internet

\begin{tabular}{|c|c|c|}
\hline Dimensão & Itens indicados pelos alunos & $\begin{array}{c}\text { Proporção } \\
\text { do item } \\
n=148\end{array}$ \\
\hline \multirow{2}{*}{$\begin{array}{l}\text { Perfil psicológico } \\
\text { do internauta }\end{array}$} & $\begin{array}{l}\text { Hackers, invasores da sua privacidade, pessoas que } \\
\text { podem ver suas coisas pessoais, invasores de conta }\end{array}$ & $16 \%$ \\
\hline & $\begin{array}{l}\text { Pessoas com más intenções, pessoas perigosas, } \\
\text { pessoas estranhas, gente doida, pedófilos }\end{array}$ & $3 \%$ \\
\hline \multirow{4}{*}{$\begin{array}{l}\text { Conteúdo veiculado } \\
\text { na Internet }\end{array}$} & Vírus & $23 \%$ \\
\hline & $\begin{array}{l}\text { Conteúdo impróprio: besteiras, coisas feias, coisas } \\
\text { ruins, sites que direcionam para besteiras, polêmica, } \\
\text { anúncios que podem atrapalhar, sites inapropriados, } \\
\text { sites não confiáveis, sites proibidos ou vídeos proibidos } \\
\text { para menores, mensagens maliciosas, coisas } \\
\text { inapropriadas, coisas indesejáveis }\end{array}$ & $13 \%$ \\
\hline & $\begin{array}{l}\text { Conteúdo falso: informações falsas, perfil falso, páginas } \\
\text { falsas, propagandas enganosas }\end{array}$ & $10 \%$ \\
\hline & Jogos perigosos & $2 \%$ \\
\hline \multirow{3}{*}{$\begin{array}{l}\text { Comportamento do } \\
\text { aluno na Internet }\end{array}$} & Exposição exagerada & $1 \%$ \\
\hline & $\begin{array}{l}\text { Compras em sites desconhecidos, curiosidade de entrar } \\
\text { em site falso, entrar em sites estranhos }\end{array}$ & $2 \%$ \\
\hline & Total 31 itens & $70 \%$ \\
\hline
\end{tabular}

Fonte: Pesquisa da autora (2018)

Tabela 3.2 - Perdas e danos no uso da Internet, por área afetada

\begin{tabular}{|c|c|c|}
\hline Área afetada & Itens indicados pelos alunos & $\begin{array}{l}\text { Proporção } \\
\text { do item } \\
n=148\end{array}$ \\
\hline \multirow{5}{*}{$\begin{array}{l}\text { Integridade do } \\
\text { aluno }\end{array}$} & $\begin{array}{l}\text { Violência sexual: abuso infantil, sermos bolinados, } \\
\text { assédios, estupro ou prostituição }\end{array}$ & $8 \%$ \\
\hline & $\begin{array}{l}\text { Agressão verbal: insultos, comentários arrogantes, } \\
\text { cyberbullying ou "zuar você" }\end{array}$ & $7 \%$ \\
\hline & Segurança física: ameaças e sequestro & $3 \%$ \\
\hline & $\begin{array}{l}\text { Segurança patrimonial: fraudes, roubos, golpes, perder } \\
\text { tudo }\end{array}$ & $4 \%$ \\
\hline & $\begin{array}{l}\text { Invasão da privacidade: pegar meu número de casa, } \\
\text { pegar seu e-mail, podem postar suas coisas, usar } \\
\text { minhas coisas ou ver coisas pessoais }\end{array}$ & $6 \%$ \\
\hline Equipamentos & $\begin{array}{l}\text { Pode dar problema técnico no computador ou pode } \\
\text { danificar o computador, pode dar problema no } \\
\text { computador }\end{array}$ & $2 \%$ \\
\hline Total & 25 itens & $30 \%$ \\
\hline
\end{tabular}

Gráfico 5.1 - Proporção de alunos, por ação com TDIC

Apresentou via Skype para convidados

Apresentou slides oralmente na turma

Compartilhou docs com professor/colegas

Produziu slides no Google Drive

Produziu slides no PowerPoint

Escreveu trabalho sobre o assunto

Selecionou informações relevantes

Fez busca na Internet

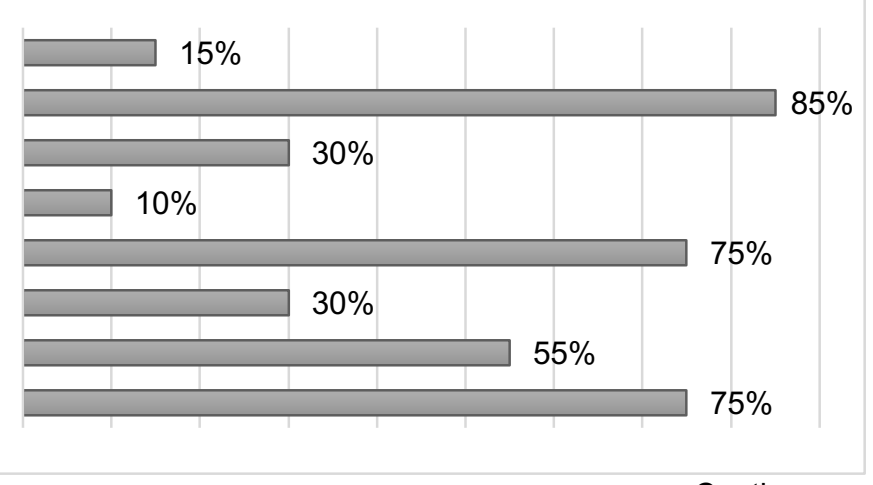

Fonte: Pesquisa da autora (2018) 
Gráfico 5.2 - Proporção de alunos, por dificuldades para usar o Blog

Habilidade tecnológica

$30 \%$

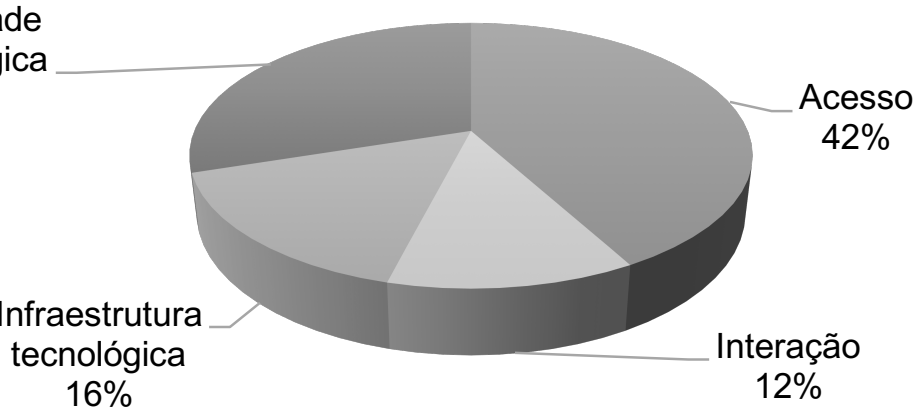

Fonte: Pesquisa da autora (2018)

Gráfico 5.3 - Proporção de alunos, por sugestão de mudança para as Oficinas

\begin{tabular}{|c|c|}
\hline \begin{tabular}{l} 
Não \\
responderam ou \\
não sabiam \\
Apoio às $\quad 37 \%$ \\
disciplinas, \\
provas externas \\
e pesquisas \\
$6 \%$ \\
\multicolumn{2}{c}{ Mais aulas no } \\
Laboratório \\
$6 \%$
\end{tabular} & $\begin{array}{c}\text { Mais } \\
\text { computadores, } \\
\text { mais acesso à } \\
\text { internet e ao Blog } \\
22 \%\end{array}$ \\
\hline
\end{tabular}

Fonte: Pesquisa da autora (2018)

Gráfico 5.4 - Local de cesso dos alunos ao Blog

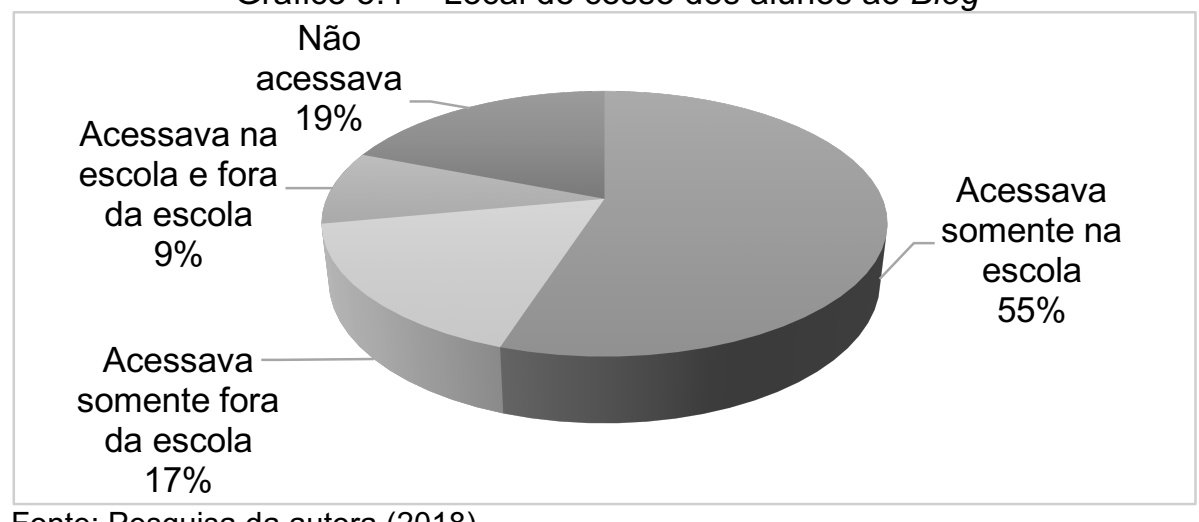

Fonte: Pesquisa da autora (2018) 


\section{APÊNDICE P - Especificações no Blog Pesquisa Nobre}

Quadro 4.2 - Especificações no Blog Pesquisa Nobre

\begin{tabular}{|c|c|}
\hline Item & Descrição \\
\hline Proprietário & Google \\
\hline Página oficial & www.blogger.com \\
\hline Aplicativo & Blogger \\
\hline Hospedagem & Blogspot \\
\hline Endereço & pesquisanobre.blogspot.com \\
\hline Administrador & $\begin{array}{l}\text { A pesquisadora (passará a ser administrado pela escola a partir da } \\
\text { defesa da tese). }\end{array}$ \\
\hline Autores & $\begin{array}{l}\text { A pesquisadora, sua orientadora e os professores das Oficinas de } \\
\text { Orientação de Estudos. }\end{array}$ \\
\hline Leitores & Agentes da Escola Estadual Fernando Nobre e público em geral. \\
\hline Acesso & Público \\
\hline Layout & $\begin{array}{l}\text { Além das postagens, foram utilizadas a organização dos conteúdos em } \\
\text { páginas e a inserção de gadgets como links, imagens e enquetes. }\end{array}$ \\
\hline Objetivo & $\begin{array}{l}\text { Contribuir para a construção de conhecimentos e desenvolvimento de } \\
\text { habilidades e atitudes necessárias às pesquisas escolares e à } \\
\text { navegação em ambiente virtual. }\end{array}$ \\
\hline Postagens & $\begin{array}{l}\text { Comunicação do conteúdo das Oficinas de Orientação de Estudos, } \\
\text { orientação para as atividades discentes, provocações cognitivas, com } \\
\text { indicação de sites, arquivos em (.PDF), vídeo, slides etc. }\end{array}$ \\
\hline Gadget - Links & $\begin{array}{l}\text { Endereçamento direto a blogs e outros sites com teor relacionado aos } \\
\text { conteúdos das Oficinas. }\end{array}$ \\
\hline Gadget - Imagem & $\begin{array}{l}\text { Registro em fotos de eventos realizados nas Oficinas, mapas e outras } \\
\text { imagens de interesse. }\end{array}$ \\
\hline Gadget - Enquetes & $\begin{array}{l}\text { Enquetes ou votação usadas para levantamento de questões em algum } \\
\text { tema de interesse das Oficinas. }\end{array}$ \\
\hline Páginas & $\begin{array}{l}\text { Modo de organização do conteúdo das postagens de acordo com o } \\
\text { planejamento das Oficinas. }\end{array}$ \\
\hline $\begin{array}{l}\text { Página Organização } \\
\text { para os estudos }\end{array}$ & $\begin{array}{l}\text { Vincula as postagens que abordam temas que sugerem como se } \\
\text { organizar para focar nos estudos: hábitos de estudo; organização do } \\
\text { tempo, do espaço, do material escolar; relacionamento e } \\
\text { comportamento em ambiente presencial e virtual são alguns exemplos. }\end{array}$ \\
\hline $\begin{array}{l}\text { Página } \\
\text { Orientação para } \\
\text { pesquisa escolar }\end{array}$ & $\begin{array}{l}\text { Vincula postagens com conteúdos que abordam técnicas de estudo e } \\
\text { de pesquisa na Internet, tais como: a importância da pesquisa escolar, } \\
\text { como fazer busca e seleção de dados na Internet, como usar os dados } \\
\text { e informações, como fazer apresentações de trabalhos escolares com } \\
\text { uso de TDIC, como fazer referências nos trabalhos, ética e normas } \\
\text { técnicas. Também reúne as postagens com orientações para as } \\
\text { atividades e trabalhos de pesquisas escolares específicas. }\end{array}$ \\
\hline $\begin{array}{l}\text { Página } \\
\text { Caindo na rede }\end{array}$ & $\begin{array}{l}\text { Vincula as postagens que compartilham os trabalhos de pesquisas } \\
\text { escolares e demais atividades do processo de ensino-aprendizagem } \\
\text { nas Oficinas, isto é, apresentação e publicação de produtos em } \\
\text { diversas mídias como vídeo, texto escrito, imagens, slides, portfólios } \\
\text { digitais etc. }\end{array}$ \\
\hline $\begin{array}{l}\text { Função educativa dos } \\
\text { comentários }\end{array}$ & $\begin{array}{l}\text { Com os comentários (relatos, dúvidas, respostas discentes), os } \\
\text { professores podem provocar cognitivamente com novas perguntas, } \\
\text { atividades e desafios, prosseguindo com uma avaliação mediadora. }\end{array}$ \\
\hline
\end{tabular}

Fonte: Pesquisa da autora (2018) 